\title{
JULAIDDIN
}
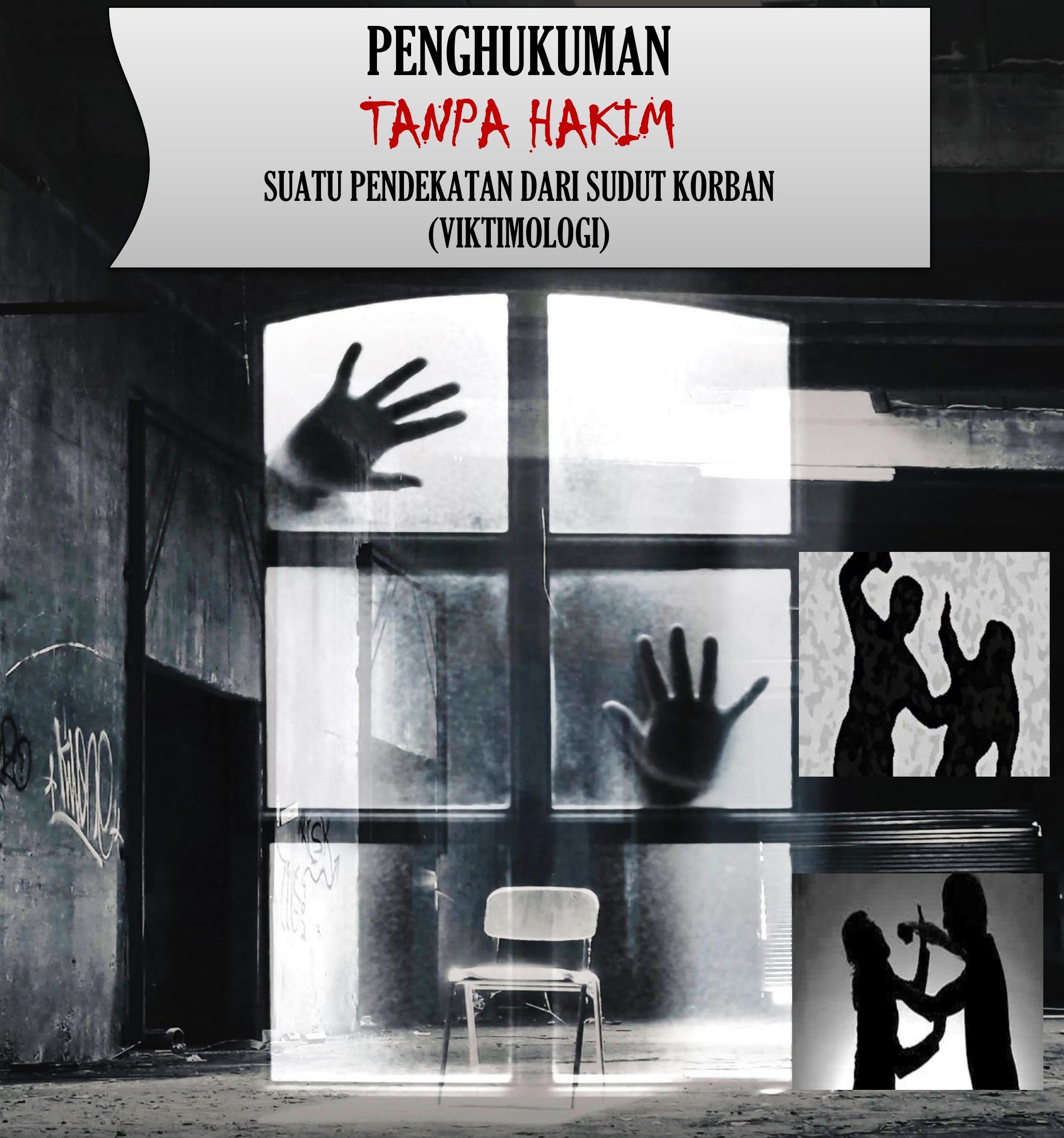

Lembaga Penelitian dan Pengabdian kepada Masyarakat Universitas Ekasakti (LPPM-UNES) 
Lembaga Penelitian dan Pengabdian Kepada Masyarakat (LPPM)

\author{
PENGHUKUMAN \\ TANPA HAKIM \\ SUATU PENDEKATAN DARI SUDUT KORBAN \\ (VIKTIMOLOGI)
}

Padang, 14 Februari 2019

PENERBIT

Lemabaga Penelitian dan Pengabdian pada Masyarakat Universitas Ekasakti Padang (LPPM-UNES) 
Penulis

Editor :

Penyuting

Desain Sampul
: Julaiddin, SH., MH

: Dr. Otong Rosadi, SH., M.Hum

: J. Sam Miekhel

: Henny Puspita Sari, SP., MP

\section{Penerbit :}

LPPM-UNES

\section{Redaksi :}

Jalan Veteran Dalam No. 26 B.

Padang (25113)

Telepon (0751) 28859-26770

Fax (0751) 32694

E-mail : lppmunes1@gmail.com

\section{ISBN : 978-602-53692-3-0}

Copyright $@ 2017$ pada LPPM UNES

Hak Cipta $\odot$ dilindungi Undang-undang pada pengarang

Hak penerbitan pada LPPM UNES

Cetakan Pertama : Februari 2019

\section{Cetakan Pertama, Februari 2019}

Hak cipta dilindungi undang-undang

Dilarang memperbanyak karya tulis ini dalam bentuk dan dengan cara apapun tanpa ijin tertulis dari penerbit 


\section{KATA PENGANTAR}

Puji syukur saya panjatkan kepada Allah SWT atas kesehatan yang Allah karuniakan kepada penulis, sehingga dapat menguraikan pemikiran-pemikiran yang terbatas ini. Dengan izin serta kehendak-Mu jualah maka penulis dapat mencurahkan pemikiran dalam karya ini. Karya ini, bila dibandingkan dengan ahli-ahli hukum lain, maka belum seberapa pemikiran dari penulis ini. Dengan keterbatasan dan kemampuan inilah maka penulis dapat menyumbangkan untuk menambah cakrawala perkembangan ilmu hukum viktimologi Indonesia.

Buku ini diberi judul "Penghukuman Tanpa Hakim" ini adalah merupakan suatu penelusuran/studi literatur yang penulis lakukan dan perenungan baik secara langsung maupun tidak langsung, atas tindakan yang dilakukan oleh oknum yang tidak bertanggungjawab. Buku ini merupakan panduan hasil bacaan dan renungan penulis, sebagai sumbangan bagi pengembangan ilmu hukum secara umum, khususnya ilmu viktimologi (ilmu tentang korban kejahatan). Guna lain hadirnya buku ini untuk menimbulkan rangsangan bagi mahasiswa (baik dalam perkuliahan maupun diskusi ilmiah) sebagai ikhtiar untuk mengembangkan ilmu hukum.

Penulis sangat menyadari, bahwa dalam penulisan buku ini masih banyak kekurangan serta kesempurnaannya, namun penulis mengharapkan kritikan, masukan yang professional agar dalam kelanjutan penulisan buku ini akan lebih sempurna. Buku ini Kupersembahkan untuk istriku yang tercinta. Rosniwati, serta anak-anak yang aku sayangi Henny Puspita Sari.SP., MP, Rangga Prayitno, SH, J Sam Miekhel, Saras Putri wulandari, Rionaldo.

Padang, 2013

Penulis

Julaiddin Samu.S.H.M.H. 


\section{DAFTAR ISI}

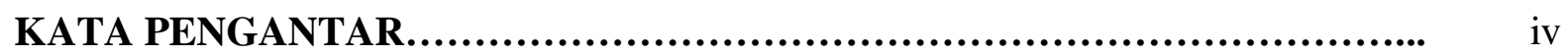

DAFTAR ISI................................................................... iv

BAB I PENDAHULUAN.......................................................... 1

A. Pendekatan Deskriptif (The Description Approach).......................... 8

B. Pendekatan Sebab Akibat (The Causal Aproach) secara Kriminologi dan Viktimologi .............................................................................................. 10

C. Apakah yang di artikan dengan "Cause" dalam Kriminologi dan Viktimologi............................................................................................ 11

BAB II PERKEMBANGAN VIKTIMOLOGI DAN KRIMINOLOGI................... 16

A. Viktimologi dan Kriminologi...................................................................... 16

1.1.1 Sejarah Viktimologi........................................................................... .. 18

1. Kedudukan Viktimologi..................................................................... 20

2. Pengertian Korban Dalam Kajian Viktimologi..................................... 23

3. Jenis Korban Dalam Masyarakat........................................................... 27

4. Pembagian Viktimologi..................................................................... 32

5. Tujuan Viktimologi..................................................................... 38

1.1.2 Berbagai Aspek Masalah Korban.............................................................. 39

1. Luka Fisik.................................................................................. 40

2. Kerugian Materi........................................................................... 40

3. Kerugian Sosial dan Psikologis............................................................. 41

4. Lamanya Penderitaan........................................................................... 44

5. Perhatian Terhadap Korban Tindak Pidana........................................... 45

1.1.3 Peranan Dan Risiko Korban (Viktimisasi) ............................................. 47

1. Peranan Korban............................................................................. 47

2. Resiko Korban................................................................................ 50

1.1.4 Restitusi Dan Kompensasi..................................................................... 56

1. Istilah Restitusi dan Kompensasi..................................................... 56

2. Sejarah Singkat Restitusi.................................................................. 57

3. Kompensasi............................................................................... 62

4. Viktimologi dalam Kaitan Penanggulangan Kejahatan.......................... 63

a. Pengertian Viktimologi..................................................................... 63

b. Viktimologi dalam Perkembangan.................................................... $\quad 65$

c. Ruang Lingkup Viktimologi.............................................................. $\quad 70$

d. Korban dan Kejahatan "Meliputi beberapa hal"............................... 71

5. Hak dan Kewajiban Korban.................................................................. 77

6. Kewajiban Korban.......................................................................... 81

7. Kejahatan................................................................................... 82

8. Hubungan Korban Kejahatan dan Pelaku Kejahatan............................. 85

9. Manfaat Viktimologi........................................................................ 87

10. Viktimologi dan Kriminologi.............................................................. $\quad 90$

11.Viktimologi dan Ilmu Hukum................................................................ 96 
BAB III JUDGMENT WITHOUT JUSTICE (PENGHUKUMAN TANPA HAKIM). 97

A. Pengusutan Perkara Kriminal Melalui Sarana Teknik dan Sarana Hukum (Untuk Mencapai Keadilan dan Kepastian Hukum)...

101

B. Hubungan Viktimologi dan Kriminologi tentang adanya Interogasi Terhadap Tersangka Yang Sudah Jelas Kesalahannya.....

C. Hubungan Viktimologi dengan Integrasi Terhadap Tersangka Yang belum Jelas Kesalahannya, Atau Kesalahannya Masih Diragukan....

D. Viktimologi dan Kriminolodi dalam Penggunaan Metode "Memperdaya Tersangka" atau "Methods of Detecting Deception" atau Bisa Disebut "Association Method"

E. Dalam Pelaksanaan Suatu Tindakan Hukum "Integorasi Terhadap Saksi" Dikaitkan dengan Sebuah Tinjauan Viktimologi dan Kriminologi.

BAB IV KEPENTINGAN KORBAN DAN TERSANGKA DALAM PROSES PERADILAN PIDANA

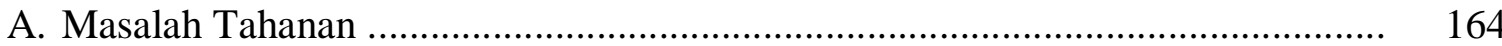

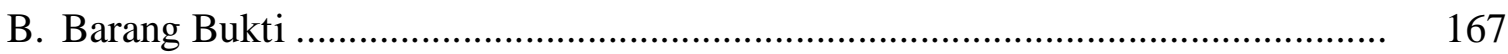

C. Penyelesaian Perkara ................................................................................... 167

D. Tentang permasalahan Pembiayaan Pentidikan, Penyidangan dan Penyelesaian Perkara antara lain

E. Untuk kepentingan penyidikan maka memerlukan kepastian hukum dengan mengunakan penelitian secara Statistik agar lebih jelas kebenaran atau jumlah kejahatan yang secara pasti

BAB V KEHORMATAN ADALAH HARGA MATI 
$B A B I$

PENDAHULUAN

\section{Pendahuluan}

Banyak hal atau unsur atau prinsip penting dalam Negara hukum. Salah satu unsur atau prinsip yang terpenting dalam negara hukum adalah adanya penghargaan dan komitmen menjunjung tinggi hak asasi manusia serta jaminan semua warga Negara bersamaan kedudukannya di dalam hukum (equality before the law). ${ }^{1}$ Sehubungan dengan hal ini, dalam Pasal 27 ayat (1) UUD 1945 mengatur penegasan bahwa: "Segala warga Negara bersamaan kedudukannya di dalam hukum dan pemerintahaan dan wajib menjunjung hukum dan pemerintahan itu dengan tidak ada kecualinya."

Prinsip demikian, idealnya bukan hanya sekedar dianut dalam konsepsi negara hukum dalam banyak tradisi hukum atau tertuang di dalam Undang-Undang Dasar 1945 dan perundang-undangan, semata. Namun yang terpenting dalam penegakan hukum adalah dalam pelaksanaan atau implementasinya agar setiap pencari keadilan mempunyai kepastian hukum yang jelas. Sebagaimana diamanatkan dalam UUD 1945 Pasal 27 ayat (1) tersebut agar setiap warga Negara (masyarakat) merasakan kedamain dan keadilan dalam kehidupan dan penghidupan yang layak. Dalam praktek penegakan hukum sering kali diwarnai dengan hal-hal yang bertentangan dengan prinsip-prinsip hukum tersebut. Misalnya penganiayaan terhadap pelaku kejahatan yang belum ada kepastian yang sesuai persedur hukum yang berlaku, namun demi dan/atau mengejar pengakuan selalu timbul intimidasi, rekayasa perkara, pemerasan, dan sebagainya. ${ }^{2}$

Kemudian pihak korban juga merasakan terabaikan hak-haknya, antara lain dakwaan lemah, tuntutan ringan, tidak mengetahui perkembangan dalam suatu

\footnotetext{
${ }^{1}$ Adanya penjaminan hak asasi manusia tidak hanya merupakan unsur negara dalam tradisi hukum Anglo Saxon, namun juga menjadi unsur dalam tradisi hukum Eropa Kontinental, lihat sebagaimana disebut dalam kata pengantar Dekan Fakultas Hukum Universitas Ekasakti dalam penerbitan buku ini.

${ }_{2}$ Bambang Waluyo, Viktimologi perlindungan Korban dan Saksi. Jakarta. Penerbit. Sinar Grafika, 2011 Hlm.. 1
} 
penanganan perkara, tidak menerima kompensasi dan tidak terpenuhinya hak-hak yang lain.

Kejahatan dan penjahat telah sering dipermasalahkan dalam bentuk penelitian, penulisan buku ini, sampai dengan pengkajian dalam bentuk seminar, simposium, dan penulisan artikel dalam koran, media elektronik yang mengandung kajian tentang ilmu viktimologi yang mana hal tersebut adalah tentang korban dari segala aspek kejahatan yang mengandung arti terpenting dalam perlindungan korban dari hasil kejahatan baik yang telah terungkap maupun masih dalam penyelidikan dari aparat penegak hukum. Untuk itu, dengan bekerja samanya Kepolisian dengan masyarakat untuk mengungkap segala aspek kejahatan baik ilmu hukum Perdata maupun ilmu hukum Pidana. Oleh karena itu, tanpa adanya kerja sama aparat penegak hukum (kepolisian khususnya) dengan masyarakat maka tidak akan mungkin menciptakan kondisi yang lebih kondusif untuk mengungkap segala peristiwa yang dikehendaki oleh hukum itu sendiri. Dengan melibatkan tokoh masyarakat maupun tokoh adat, ini adalah merupakan langkah untuk pencapaian suatu penegakan hukum. Dengan beberapa kasus yang sangat menyeramkan bangsa ini dimana seolah-olah para penegak hukum membisu seribu bahasa akibat adanya intimidasi dalam suatu penyelesaian sengketa, yang mana peristiwa tersebut yang menjadi korban adalah masyarakat yang tidak mempunyai kemampuan baik itu secara hukum maupun secara vinansial. Dengan hal-hal tersebut apakah hak-hak si korban hanya dipercayakan kepada pemerintah khususnya korban diwakilkan dalam proses hukum oleh Jaksa penuntut umum sedangkan hak-hak lainya terabaikan begitu saja. ${ }^{3}$

Kalau orang mempermasalahkan kejahatan, maka pada hakikatnya ada beberapa komponen yang perlu diperhatikan dan atau dikaji. Lajimnya orang cuma memperhatikan dalam analisis kejahatan hanya kompenen penjahat, undangundang, dan penegak hukum serta intraksi antara tiga komponen itu. Untuk itu

\footnotetext{
3 Julaiddin. Materi Bahan Perkuliahan tentang Korban Kejahatan (Viktimologi) Penghakiman tanpa Hakim tahun Akademik 2013 pada Fakultas Hukum Universitas Ekasakti.
} 
apabila kita mempersoalkan faktor korban, analisisnya belum dikupas secara bulat dan tuntas. ${ }^{4}$

Untuk selanjutnya penulis memperjelas secara singkat arti dari pada Viktimologi. Viktimologi, secara singkat, adalah disiplin ilmu yang membahas dan atau mempelajari tentang korban dalam segala aspek dan fasetnya. Pada tahap permulaan, aspek dan faset kepidanaan atau kriminologi yang lebih menjadi tumpuan perhatian. ${ }^{5}$

Permasalahan viktimologi lebih luas cakupan, ruang lingkupnya antara lain; penebangan liar pohon-pohon bakau di tepi pantai sangat jelas akan mempunyai dampak negatif bila dihubungkan dengan ilmu viktimologi (Ilmu yang mempelajari tentang korban) terhadap para nelayan, pencemaran sungai bukan saja menjadi keprihatinan ilmu lingkungan, namun pencemaran sungai juga di permasalahkan karena berkemungkinan adanya korban bisa saja terjadi dalam suatu peristiwa yang berkaitan dengan kehidupan manusia yang mana sungai tersebut dapat dibutuhkan dalam hal kebutuhan manusia, hewan, maupun tumbuhtumbuhan lainnya akibat dari pada penyalahgunaan sungai tersebut.

Melalui pandangan Kriminologi dan Viktimologi peran serta untuk perlindungan hukum bagi anak di Indonesia tidak dapat terabaikan begitu saja, apalagi telah marak di perbincangkan di tengah-tengah masyarakat pada era globalisasi yang semakin berkembang, pembicaraan tentang anak dan perlindungannya tidak akan pernah berhenti sepanjang sejarah kehidupan, oleh karna itu anak adalah generasi penerus bangsa dan penerus pembangunan, yaitu generasi yang dipersiapkan sebagai subjek pelaksana pembangunan yang berkelanjutan dan pemegang kendali masa depan suatu Negara, tidak terkecuali Indonesia. Perlindungan anak Indonesia berarti melindungan potensi sumber daya insan dan membangun manusia Indonesia seutuhnya, menuju masyarakat yang adil dan makmur, materil spiritual berdasarkan Pancasila dan UUD 1945. Upaya-upaya perlindungan anak harus telah dimulai sedini mungkin, agar kelak dapat berpatisipasi secara optimal bagi pembangunan bangsa dan Negara. Dalam Pasal 2

\footnotetext{
4 Prof. Dr. J.E Sahetapi. Viktimologi Sebuah Bunga Rampai Penerbit. Pustaka Sinar Harapan, Jakarta, 1987, hlm.. 7.

5 Ibid.
} 
ayat (3) dan (4) Undang-Undang Republik Indonesia Nomor 4 Tahun 1979 tentang Kesejahteraan Anak, ditentukan bahwa: "Anak berhak atas pemeliharaan dan perlindungan baik semasa masih di dalam kandungan maupun sesudah dilahirkan. Anak berhak atas perlindungan dalam suatu lingkungan hidup yang dapat membahayakan atau menghambat pertumbuhan dan perkembangan dengan wajar. Kedua ayat tersebut memberikan dasar pemikiran bahwa perlindungan anak bermaksud untuk mengupayakan perlakuan yang benar dan adil, untuk mencapai kesejahteraan anak. ${ }^{6}$

Dalam mempelajari ilmu Kriminologi dan Viktimologi berbagai disiplin Ilmu sebagai pendukung dalam pembahasan buku ini, namun penulis membatasi dalam kajian Kriminologi dan Viktimologi:

1. Viktimologi adalah Ilmu yang mempelajari tentang korban dari pada tindak pidana, baik dilakukan oleh pelaku kejahatan sendiri maupun ikut sertanya korban dalam hal tindak pidana tersebut (Victimology Crimes);

2. Kriminologi adalah Ilmu yang mempelajari tentang kejahatan yang berbagai bentuk baik individu maupun kelompok tertentu (Blue Collor Crime dan White Collor Crime).

Untuk itu dalam ilmu kriminologi dan Viktimologi, terhadap hak-hak tersangka dan atau terdakwa lebih populer diatur di dalam Pasal 50 s/d Pasal 68 Undang-Undang Nomor 8 Tahun 1981 tentang Hukum Acara Pidana (KUHAP) dengan tegas dalam Pasal 50 memberikan hak kepada tersangka atau terdakwa dalam pasal ini adalah untuk menjauhkan kemungkinan terkatung-katungnya nasib seorang disangka melakukan tindak pidana terutama mereka yang dikenakan penahana, jangan sampai lama tidak mendapat pemeriksaan sehingga dirasakan tidak adanya kepastian hukum, adanya perlakuan sewenang-wenang dan tidak wajar. Selain itu juga untuk mewujudkan peradilan yang dilakukan dengan sederhana, cepat dan biaya ringan. Dalam penjelasan Pasal 50 s/d Pasal 68 juga mengatur hak-hak tersangka/terdakwa antara lain: hak untuk segera mendapatkan pemeriksaan, hak untuk diberikan kesalahan, hak untuk didampingi oleh penasehat

\footnotetext{
6 Nashriana. Perlindungan Hukum Pidana Bagi Anak di Indonesia Penerbit PT. Raja Grafindo Persada Jakarta, 2011, hlm. 1-2.
} 
hukum. pengacara, hak untuk mendapatkan juru bahasa, hak untuk segera di ajukan ke pengadilan perkaranya, hak untuk mendapatkan putusan dari hakim yang seadiladilnya, hak untuk mendapatkan kunjungan dari keluarga, dan lain-lain yang dirasa demi kepentingan terdakwa/tersangka. Untuk itu sangatlah mendapatkan perhatian yang istimewa bagi terdakwa maupun tersangka, serta perundang-undangan yang lain yang terkait, bahkan juga dalam Undang-Undang Dasar 1945. Untuk itu sangatlah penting kiranya para ahli hukum baik baru pemula ataupun telah senior untuk mempelajari ilmu Viktimologi dan Kriminologi. Apabila kita teliti secara seksama bahwa di dalam KUHAP tersebut lebih banyak mengatur hak-hak tersangka atau terdakwa. Akan tetapi untuk hak-hak korban (Viktimologi) selalu terabaikan baik dalam segi pengaturannya maupun ketegasannya dan tidak seimbang dalam penegakan hukum karena semerta merta korban adalah yang sangat bersalah dalam hal ini.

Dalam proses penegakan hukum (peradilan pidana) yang bertumpu pada hukum pidana dan hukum acara pidana. Kalau orang mempermasalahkan kejahatan, maka pada hakikatnya ada beberapa komponen yang perlu di perhatiakan dan atau di kaji. Lazimnya orang Cuma memperhatikan dalam analisis kejahatan hanya komponen penjahat, undang-undang, dan penegak hukum serta interaksi antara ketiga komponen itu. Masalah kontelasi masyarakat dan faktor lainnya, kalaupun di kaji, lebih banyak di soroti oleh sosiologi dan kriminologi. Dalam pada itu komponen korban hampir terlupakan analisis ilmia. Kalaupun di persoalkan faktor korban, analisisnya belum dikupas secara bulat dan tuntas.

Viktimologi secara singkat adalah ilmu atau disiplin yang membahas permasalahan korban dalam segala aspek dan fasenya, dan pada tahap permulaan, aspek dan fasenya kepemidanaan dan kriminologi yang lebih menjadi tumpuan perhatian. $^{7}$

Memang bila kita telusuri secara utuh dan seksama KUHP dalam mengatur hak-hak korban tidak sebanding dengan banyaknya hak-hak tersangka dan/atau terdakwa. Karena didalam perkembangannya terlihat cukup mengembirakan regulasi terhadap hak-hak korban, saksi dan juga hak-hak masyarakat. Ini semua

\footnotetext{
7 J.E.Sahetapy, Op-Cit, hlm..7-8.
} 
tidak terlepas dari bergulirnya era reformasi, globalisasi dan demokratisasi. Dengan semangat reformasi, banyak perundang-undangan, bahkan Undang-Undang dasar Negara Republik Indonesia tahun 1945 telah beberapa kali di amandemen. Dalam rentang waktu itu telah lahir undang-undang, antara lain:

a) Undang-Undang Nomor 31 Tahun 1999 tentang Pemberantasan Tindak Pidan Korupsi jo. Undang-Undang Nomor 20 Tahun 2000 (antara lain mengatur peran serta masyarakat);

b) Undang-Undang Nomor 39 Tahun 1999 tentang Hak Asasi Manusia;

c) Undang-Undang Nomor 26 Tahun 2000 tentang Pengadilan Hak Asasi Manusia (HAM);

d) Undang-Undang Nomor 15 Tahun 2003 tentang Pemberantasan Tindak Pidana Terorisme (jo Perpu Nomor 1 Tahun 2002) ${ }^{8}$

e) Undang-Undang Nomor 23 Tahun 2002 tentang Perlindungan Anak (lihat juga Undang-Undang Nomor 3 Tahun 1997 tentang Peradilan Anak);

f) Undang-Undang Nomor 4 Tahun 2004 yang dicabut oleh Undang-Undang Nomor 48 Tahun 2009 tentang Kekuasaan Kehakiman;

g) Undang-Undang Nomor 23 Tahun 2004 tentang Penghapusan Kekerasan Dalam rumah Tangga;

h) Undang-Undang Nomor 13 Tahun 2006 tentang Perlindungan Saksi dan Korban;

i) Undang-Undang Nomor 23 Tahun 2007 tentang Tindak Pidana Perdagangan Orang.

Sebagai pelaksanaan Undang-Undang tersebut di tindak lanjuti dengan terbitnya beberapa Peraturan Pemerintah, antara lain:

a) Peraturan pemerintah Nomor 2 Tahun 2002 tentang Tata Cara Perlindungan terhadap Korban dan saksi dalam Pelanggaran Hak Asasi Manusia;

${ }^{8}$ Op-Cit. Bambang Waluyo, Viktimologi Perlindungan Korban dan Saksi. Penerbit Sinar Grafiak .Jakarta. 2011.Hlm..4 
b) Peraturan Pemerintah Nomor 3 Tahun 2002 tentang Kompensasi, Restitusi, dan Rehabilitasi terhadap Korban Pelanggaran Hak Asasi Manusia yang Berat;

c) Peraturan Pemerintah Nomor 71 Tahun 2000 tentanm Tata cara Pelaksanaan Peran Serta Manyarakat dan Pemberian Penghargaan dalam Pemecahan dan Pemberantasan Tindak Pidana Korupsi;

d) Peraturan Pemerintah Nomor 44 Tahun 2008 tentang Pemberian Kompensasi, Restitusi, dan Bantuan kepada Saksi dan Korban;

e) Peraturan Pemerintah Nomor 57 Tahun 2003 tentang Tata cara Perlindungan Khusus Bagi Pelapor dan Saksi Tindak Pidana Pencucian Uang. ${ }^{9}$

Menurut pandangan penulis, bahwa hukum akan lebih jelas dan terang benderang penjelasannya apabila dalam penulisan tersebut berdasarkan teori sebagi pendukung kebenaran dalam penuliasan. Istilah hukum pidana bermakna jamak. Dalam arti obyektif, yang juga sering disebut jus poenale meliputi:

1. Perintah dan larangan, yang atas pelanggarannya atau pengabaiannya telah ditetapkan sanksi terlebih dahulu oleh badanbadan Negara yang berwenang; peraturan-peraturan yang harus di taati dan diindakan oleh setiap orang;

2. Ketentuan-ketentuan yang menetapkan dengan cara apa atau alat apa dapat diadakan reaksi terhadap pelanggaran peraturan-paraturan itu d.k.l. hukum penentiair atau hukum sanksi.

3. Kaidah-kaidah yang menentukan ruang lingkup berlakunya peraturan-peraturan itu pada waktu dan di wilaya Negara tertentu.

Ius poenale secara singkat dapat dirumuskan sebagai sejumlah peraturan hukum yang mengandung larangan dan perintah atau keharusan yang terhadap pelanggarannya di ancam dengan pidana (sanksi hukum) bagi mereka yang mewujudkannya. Hukum pidana formil (law of criminal procedure) atau hukum

\footnotetext{
9 Bambang Waluyo, Viktimologi Perlindungan Korban dan Saksi.penerbit. Sinar Garafika Jakata. Tahun 2011 hlm.. 5 .
} 
acara pidana secara singakat dapat dirumuskan sebagai hukum yang menetapkan cara Negara mempergunakan haknya untuk melaksanakan pidana, dari uraian tersebut diatas, jelaslah bahwa hak Negara untuk memidana haruslah berdasarkan hukum pidana materiel, dan karena itu adanya Kitab Undang-undang Hukum Acara Pidana (KUHP) memungkinkan berlakunya hukum pidana materie dalam kenyataan ${ }^{10}$. Kedua bidang hukum tersebut sangat erat kaitannya. Yang pertama menentukan apa yang dilarang dan yang diperintahkan untuk dilakukan, sedangkan yang kedua adalah menetukan pedoman dan cara mentukan perbuatannya itu.

Suatu negara hukum atau yang berdasarkan rule of law tidaklah cukup memiliki kitab Undang-Undang Hukum Acara Pidana dan atau hukum pidana tertulis lain atau pun hukum pidana tak tetulis yang tidak boleh bertentangan dengan prinsip-prinsip dan asas Negara hukum atau rule of law. Bersamaan dengan penegakan hukum tidak terlepaskan pengertian dan obyek Kriminologi. Kriminologi dalam artian sempit (yang dipergunkana dalam buku ini) adalah mempelajari kejahatan, sedangkan viktimologi adalah mempelajari tentang korban kejahatan untuk itu antara kriminologi dengan viktimologi tidak dapat di pisahakan karena antara keduanya saling bertautan atau saling berkaitan antar satu dengan yang lainnya. Akan tetapi pengertian kriminologi secara luas adalah mempelajari tentang penology dan metode-metode yang berkaitan dengan kejahatan dan masalah prevensi kejahatan dengan tindakan-tindakan yang bersifat non-punitif. Secara tegas dapat dikatakan bahwa batasan kejahatan dalam arti yuridis adalah tingkah laku manusia yang dapat dihukum berdasarkan hukum pidana. ${ }^{11}$

Tingkah laku manusia dimaksud dapat dipelajari dengan menggunakan 3 (tiga) dasar bentuk pendekatan secara Kriminologi dan Viktimologi yakni:

\section{A. Pendekatan Deskriptif (The Description Approach)}

Kriminologi dalam arti pendekatan secara deskriptif berarti:’Observasi dan pengumpulan fakta-fakta tentang kejahatan dalam pelaku kejahatan";sedangkan dalam Viktimologi adalah pembuktian antara kebenaran pelaku kejahatan dengan korban suatu tindak pidana kejahatan dengan segala cara modus operandi yang timbul dalam suatu peristiwa pidan yang terjadi seperti:

\footnotetext{
10 A. Zainal Abidin Farid, Hukum Pidana I. Penerbit Sinar Grafika .Jakarta, 1995, hlm.. 2.

${ }^{11}$ Romli Atmasasmita, Bunga Rampai Kriminologi. Penerbit. CV. Rajawali. Jakarta 1984. Hlm.. 1-2.
} 
a. Pelbagai bentuk tingkah laku criminal;

b. Bagaimana kejahatan tersebut dilakukan;

c. Frekuensi kejahatan pada tempat dan waktu yang berbeda-beda;

d. Usia, jenis kelamin dan cirri-ciri khas lainnya dari pelaku kejahatan;

e. Perkembangan karir seseorang pelaku kejahatan.

Apa yang telah di uraikan diatas, dapat disebut: Fenomeno-logi atau Simptomatologi-kejahatan. Hal-hal yang perlu diperhatikan dalam mempergunakan pendekatan secara deskriptif ini adalah:

1. Fakta-fakta tindaklah dapat dikumpulkan secara random, oleh karena itu fakta-fakta yang akan di peroleh harus di lakukan secara selektif yang di landaskan hipotesa-hipotesa ilmiah atau suatu kesatuan dari pada sistem hipotesa-hipotesa. Bagi para petugas lapangan (field-workers) hal itu berarti bahwa, untuk memperoleh fakta-fakta yang dapat di pertanggung jawabkan dan berguna, lebih dulu mereka harus dapat menetapkan apa yang menjadi obyek pengumpulan data tersebut. Pendapat yang keliru apabila dikatakan bahwa ilmu pengethuan dimulai dengan observasi atau pengumpulan data, oleh karena itu sebelum melakukan pengumpulan data dilakukan, perhatian atau rasa ingin tau atas data yang ingin diperoleh, oleh karena itu harus telebih dahulu ada data untuk dapat membuktikan kebenaran hukum yang akan melandasi dasar-dasar yang akan di teliti atau untuk mewjutkan kebenaran hukum yang sebenarnya, apakah kejahatan itu semerta-merta pelaku tindak pidana yang terlebih dahulu merencanakan ataukah memang ada kesempatan atau kerja sama yang dilakuakan oleh korban sebelum timbulnya suatu peristiwa pidana.

2. Fakta semata-mata tanpa suatu penafsiran, evaluasi dan pengertian secara umum, tidaklah akan berarti. Oleh karena itu kita memerlukan pengetahuan umum tentang kehidupan dan pengalaman dalam salah satu sektor kehidupan, agar dapat diperoleh penafsiran yang tepat atas fakta-fakta yang telah dikumpulkan dengan observasi tersebut, sehingga jelas apa yang akan di lakukan dalam suatu tindakan untuk mencapai suatu kepastian hukum dan keadilan. Karena apabila tampa memberikan pembuktian yang akurat dan 
fakta-fakta yang jelas maka akan menimbulkan korban baru bagi pencari keadilan, untuk itu dalam melakukan penyelidikan harus pelakunya jelas dan terang benderang agar dalam tinkat penyidikan tidak menimbulkan kesalahan yang akan menjadi dasar dari pada jaksa penuntut umum (JPU), dan akan menajadi putusan yang salah bagi hakim. ${ }^{12}$

\section{B. Pendekatan Sebab Akibat (The Causal Aproach) secara Kriminologi dan Viktimologi}

Pendekatan terhadap kejahatan dapat dilakukan pula secara kausalitas, ini berarti penafsiran terhadap fakta-fakta dapat di pergunakan untuk mengetahui sebab musabab terjadinya kejahatan, baik di dalam kasus-kasus yang bersifat umum maupun yang bersfat individu. Dan untuk menemukan atau mengungkapkan kausalitas suatu gejala dalam kejahatan disebut Etiologi Kriminal (Etiology of Crime).

Dimasa lampau etiologi Kriminal memiliki fungsi yang penting dalam membahas Kriminologi, akan tetapi pada dewasa ini peranan penelitian atau penyelidikan secara kausa mengandung hal-hal yang bersifat kontroversi. Penyelidikan, penelitian kausalitas dalam kriminologi memiliki perbedaanperbedaan fungsional dengan penyelidikan para ahli hukm (pidana) terutama dalam usaha menemukan hubungan (kaitan) antara tingka laku individu dan suatu kejahatan tertentu. Agar dapat dilakukan penuntutan (dalam hukum pidana) haruslah dapat dibuktikan bahwa antara suatu tindakan atau perbuatan (dalam situasi tertentu). Selain dari pada disyaratkan adanya "causal-nexus" juga dalam hukum pidana, disyaratkan pula adanya "mens-rea" atau "guilt" untuk dapat membuktikan adanya pertanggung jawaban dari pada sipelaku (Criminalresponsibility). ${ }^{13}$ Dengan demikian dalam hukum pidana sesunggunya segala akibat yang beralasan dan merugikan dapat di hindarkan, sehingga hukum pidana dapat mempergunakan konsepsi"causal-nexus"secara luas dan lebih tinggi. Untuk itu

\footnotetext{
${ }^{12}$ Romli Atmasasmita, S.H., LL.M. Bunga Rampai Kriminologi. Penerbit. CV. Rajawali. Jakarta 1984. Hlm.. 2-3.

13 Ibid. Romli Atsasmita,S.H.,LL.M. Bunga Rampai Krinologi Penerbit. CV. Raja Wali. Jakarta. 1984.Hlm..4-5.
} 
disatu pihak, Hukum Pidana dalam usahanya menciptakan atau menemukan adanya unsur "pertanggung jawaban dari pada pelaku kejahatan" (kecuali dalam kasuskasus yang menyankut perusahaan) yang berhubungan dengan sebab akibat antara perbuatan yang dilarang dengan akibat yang terjadi, sedangkan dilain pihak bidang studi dari pada seorang Krimonolog dimulai pada tahap terakhir, sebagai contoh untuk pemahaman dalam penulisan buku ini maka penulis memberikan contoh; apabila hubungan sebab akibat telah terbukti, maka bagi seseorang kriminolog yang terpenting adalah bukan apakah si X sudah melakukan kejahatan, melainkan, mengapa seseorang dengan cirri-ciri tertentu malakukan kejahatan atau kejahatan tertentu.

\section{Apakah yang di artikan dengan "Cause” dalam Krinologi dan Viktimologi}

Dalam hal ini Popper berlandaskan kepada pendapat John Stuart Mill, member arti kepada "Cause" sebagai akibat "Hukum umum" maupun "kejadian tertentu". ${ }^{14}$ Dengan demikian hubungan korban dengan kejahatan mempunyai dasar cause baik secara kriminologi maupun secara viktimologi yaitu pada umumnya dikatakan hubungan korban dengan kejahatan adalah pihak yang menjadi korban sebagai akibat kejahatan.Tentu ada asap pasti ada api. Pihak tersebut menjadi korban karena ada pihak lain yang melakukan kejahatan. Memang demikianlah pendapat yang kuat selama ini yang didukung dengan fakta-fakta yang ada. Meskipun dalam prakteknya ada dinamika yang berkembang. Sebagai contoh Penulis ungkapkan yaitu kisah pembunuhan oleh premanisme yang ada di salah satu café di Jokya yang mana korbannya adalah oknum TNI, Hal lain yang disepakati dalam hubungan ini, terpenting pihak korban adalah pihak yang dirugikan. Pelaku merupakan pihak yang mengambil untung atau merugikan korban. kerugian yang sering diderita oleh korban misalnya luka fisik, mental, ekonomi, harga diri dan sebagainya. Hal tersebut berkaitan dengan status, kedudukan, posisi, tipologi korban dan sebagainya. Uraian tersebut menegaskan yang bersangkutan sebagai korban "murni” dari kejahatan. Artinya korban memang

\footnotetext{
${ }^{14}$ Ibid Hlm..5
} 
korban yang sebenar-benarnya/senyatanya. Mengapa menjadi korban, kemungkinan penyebabnya; kealpaan, kalalaian, ketidaktahuan, kurang hati-hati, kelemahan korban atau mungkin kesialan korban. ${ }^{15}$

Namun ada beberapa pendapat yang menyatakan bahwa korban dapat juga terjadi akibat dari kelalaian Negara untuk melindungi warganya, perkembangan global, faktor ekonomi, politik, sosiologis, ataupun faktor-faktor negatif yang lain, memungkinkan adanya korban tidak "murni”. Disini korban tersangkut atau menjadi bagian dari pelaku kejahatan, bahkan sekaligus menjadi pelakunya. Lebih mendalam tentang masalah ini, Hentig seperti dikutip oleh (Rena Yulia, 2010: 81) beranggapan bahwa perana korban dalam menimbulkan kejahatan adalah sebagai berikut:

1. Tindakan kejahatan memang dikehendaki oleh sikorban untuk untuk terjadi;

2. Kerugian akibat tindak kejahatan mungkin dijadikan si korban untuk memperoleh keuntungan yang lebih besar;

3. Akibat yang merugikan si korban mungkin merupakan kerja sama antara si pelaku dan si korban;

4. Kerugian akibat tindak kejahatan sebenarnya tidak terjadi bila tidak ada yang memperofokasi si korban.

Selanjutnya hubungan korban dengan pelaku dapat dilihat dari tingkat kesalahannya. Menurut Mondelsonh berdasarkan derajat kesalahannya korban dapat dibedakan menjadi 5(lima) macam, yaitu; ${ }^{16}$

a. Yang sama sekal tidak bersalah;

b. Yang korban akibat kelalaiannya;

c. Yang sama salahnya dengan pelaku;

d. Yang lebih besalah dari pada pelaku;

e. Yang korban adalah satu-satunya yang bersalah (dalam hal ini pelaku dibebaskan).

\footnotetext{
${ }^{15}$ Op-Cit, Bambang Waluyo, Viktimologi Perlindungan Korban dan Saksi. Penerbit, Sinar Grafika. Jkarta. 2011 Hlm.. 18-19.

16 Ibid., hlm.. 20.
} 
Sebenarnya, kalau kita melihat dari sudut pandang Kriminologi dan Viktimologi, banyak hubungan korban dan pelaku kejahatan, dintaranya juga dapat di kaji melalui hubungan darah, persaudaraan, family, ataupun kekeluargaan. Misalnya pencurian dalam keluarga, pelecehan seksual dan bahkan penganiyaan atau pembunuhan untuk memperebutkan harta warisan serta kekuasaan/dalam pengaruh keluarga. Sejenis hubungan ini atau hubungan orang-orang terdekat pelaku ataupun korban seperti teman, sahabat, pacar, rekan bisnis dan sebagainya. Penulis mengutip beberapa kajian yang berdasarkan hubungan dengan sasaran tindakan pelaku sebagi mana di ungkapkan dalam investigasi pembunuhan di Café maupun pembunuhan di Lapas Cebongan di Jokya melalui media elektronik TV One yaitu meliputi:

1. Korban langsung yaitu mereka yang secara langsung menjadi sasaran atau obyek perbuatan pelaku;

2. Korban langsung yaitu mereka yang meskipun tidak secara langsung menjadi sasaran perbuatan pelaku, tetapi juga mengalami penderitaan atau nestapa. Pada kasus terhadap seorang laki-laki yang mempunyai tanggung jawab menghidupi istri dan anak-anaknya, meninggalnya laki-laki tersebut merupakan korban langsung. Sedangkan istri dan anak-anaknya merupakan korban tidak secara langsung.

Fakta menunjukan bahwa sebagian besar korban merupakan korban murni atau senyatanya. Korban-korban dimaksud terjadi akibat kurangnya pemahaman hukum, akibat miras, dan kurangnya komunikasi yang berdampak pada suatu peristiwa pidana yang sangat tragis. Akan tetapi banyak juga faktor lain diluar dari pada kasus Cebongan yang menunjukan terjadinya tindak pidana misalnya Terorisme, pencurian biasa, pencurian dengan pemberatan, kekerasan,dan tindak pidana lainnya yang sering terjadi di tengah-tengah masyarakat.

Dalam suatu kehidupan manusia dengan kemajuan teknologi, globalsasi, perubahan jaman dari masa lampau kejaman moderen, banyak wenomena atau tantangan yang sangat membutuhkan ilmu pengetahuan, baik itu dalam bidang ilmu pendidikan menyangkut etika, moralitas, agama maupun kajian-kajian ilmu hukum lainya, terutama dalam kajian ilmu hukum yang menyangkut tentang 
Kriminologi (kejahatan) dan Viktimologi (Korban kejahatn) dimana hal tersebut, penulis memberikan gambaran yang senyatanya terjadi pada lingkungan masyarakat, baik yang ada di pedesaan sampai ke kota Metropolitan (Jakarta). Fakta-fakta yang menunjukan adanya kebenaran kemajuan dari suatu proses perubahan adalah dibidang komunikasi melalui telpon seluler, media elektronik, media cetak yang berdampak pada peristiwa pidana maupun korban dari peritiwa itu, dimana hal tersebut akibat penyalah gunaan dari suatu sistem elektronika yang mana pengunanya adalah pada kalangan terpelajar, pendidik, masyrakat biasa, samapai kepada anak-anak penerus regenasi masa depan bangsa. ${ }^{17}$ Akibat dari pada kemajuan elektronik itu bukan hanya pada pikiran positifnya akan tetapi negatifnya yang lebih dominan. Contoh kasus penulis utarakan dalam buku ini adalah penculikan melalui perkenalan lewat media facebook, penipuan melalui telepon seluler serta bisnis berantai melalui media elektronik. Dimana para korban kurang berhati-hati untuk menilai suatu prosen yang sedang dilakukan atau kurangnya sosialisai dari pada penegak hukum kepada masyarakatnya.

Kriminologi dan Viktimologi tidak dapat terpisahkan, karena disiplin ilmu ini bagaikan langkah kaki kanan dan kaki kiri yang saling membutukan artinya tidak mungkin adanya kejahatan tampa adanya korban dan/atau tampa adanya korban tidak mungkin adanya kejahatan. Untuk itu dalam kehidupan banyak dinamika antara korban dan kejahatan, hal tersebut disebabkan oleh banyak faktor antara lain; akibat dorongan ekonomi, politis, psikis. Memang banyak juga korban ikut andil dalam terjadinya kejahatan. Derajat kecilnya peran korban, misalnya korban lalai, hingga muncul atau terjadi tingak pidana. Dapat terjadi pula dalam korban menarik perhatian pelaku, misalnya korban menyukai memperlihatkan kekayaan, overacting, atau perilaku lain yang dapat mengugah perhatian pelaku untuk melakukan tindak pidana. Dan dapat pula terjadi bila korban seseorang perempuan yang sering berpakaian seksi dan merangsang atau tidak sopan. Bukan saja ikut andil, sering terjadi korban "sama salahnya dengan pelaku." Disini korban berpuara menjadi korban, padahal ia adalah pelaku. Misalnya pelaku bom bunuh diri,

\footnotetext{
17 Ibid, hlm.. 20 .
} 
seorang penjaga barang atau uang yang melaporkan terjadi kejahatan padahal yang bersangkutan turut serta dalam kejahatan itu. 
BAB II

\section{PERKEMBANGAN VIKTIMOLOGI DAN KRIMINOLOGI}

\section{A. Viktimologi dan Kriminologi}

Dengan adanya hubungan antara Kriminologi dan Viktimologi sudah tidak dapat diragukan lagi, karean dari satu sisi kriminologi membahas secara luas mengenai pelaku dari suatu kejahatan, sedangkan viktimologi merupakan ilmu yang mempelajari tentang korban kejahatan, sebagimana penulis meminjam pernyataan dalam suatu buku tentang urgensi perlindungan korban kejahatan oleh Dikdik M.Arif Mansur. Bahwa jika kita telaah lebih mendalam, tidak berlebihan apabila dikatana bahwa viktimologi merupakan bagian yang hilang dari krtiminologi atau dengan kaliamt lain, bahwa viktimologi tidak akan membahas bagian-bagian dari suatu kajian ilmu kriminologi. Namun pada umumnya dikatakan bahwa viktimologi lahir karena munculnya desakan perlunya pembahasan tentang masalah korban yang akan dibahas secara tersendiri.

Akan tetapi, mengenai pentingnya dibentuk viktimologi secara terpisah dari limu kriminologi mengundang beberapa pendapat para ahli hukum pidana diantaranya adalah sebagai berikut;

a) Diantara pakar hukum pidana yang berpendapat bahwa viktimologi tidak terpisahkan dari kriminologi adalah Von Hentig, H. Mannheim dan Paul Cornil. Mereka mengatakan bahwa kriminologi merupeken ilmu pengetahuan yang menganalisis tentang kejahatan dengan segala aspeknya, termasuk korban. Namun melalui penelitian yang dilakukan oleh beberapa pakar hukum pidana tersebut diatas berpendapat, bahwa kriminologi akan dapat membantu menjelaskan tentang peranan dari korban dalam suatu kejahatan dan berbagai aspek permaslahan atau persoalan yang melingkupunya.

b) Mereka menginginkan viktimologi terpisah dari kriminologi, ini adalah merupakan pendapat dari Mendelsohn. Dalam pandangan Mendelsohn tentang viktimologi mengatakan bahwa viktimologi merupakan suatu 
cabang ilmu yang memp[unyai teori dalam krimonologi, akan tetapi dalam membahas persoalan korban, viktimologi tidak hanya berfokus pada korban itu sendiri.

Khusus mengenai hubungan antara kriminologi dan hukum pidana dapat dikatakan bahwa keduanya merupakan pasangan Dwi Tunggal yang saling melengkapi karena setiap orang akan mengerti dengan jelas tentang penggunaan aturan hukum terhadap penjahat ataupun pengertian mengenai timbulnya suatu kejahatan dan cara-cara pemberantasannya sehingga dapat memudahkan penentuan adanya suatu kejahatan dan pelaku kejahatannya. Untuk dapat dimengerti dan/atau memahaminya bahwa hukum pidana hanya mempelajari delik sebagi suatu pelanggaran hukum. Sedangkan untuk pemahaman lebih lanjut dapat dikatakan bahwa, delik sebagai suatu pelanggaran hukum, sedangkan untuk mempelajari bahwa delik merupakan perbuatan manusia atau suatu gejalah sosial adalah kriminologi.

Seorang pakar hukum pidana yang juga sebagi penggerak ilmu viktimologi adalah Prof. Dr. J.E Sahetapy memberikan suatu pandangan atau pendapat bahwa krimionologi dan viktimologi merupakan sisi dari mata uang yang saling berkaitan. Akan tetapi perhatian tentang akan kejahatan yang ada, tidak seharusnya hanya berputar sekitar munculnya kejahatan saja, akan tetapi juga akibat dari kejahatan, disini akan terlihat perhatian akan bergeser tidak hanya kepada pelaku kejahatan, akan tetapi juga kepada posisi korban dari kejahatan itu. Hal ini juga dibahas oleh bebrapa pakar hukum pidana lainnya dalam memperhatikan adanya hubungan ini, atau setidk-tidaknya perhatian atas terjadinya kejahatan tidak hanya satu sudut pandang saja, namu penulis berpendapat bahwa tidak akan mungkin timbul suatu peristiwa pidana apabila tidak mempunyai korban, atau tidak akan mungkin menjadi korban apabila tidak ada suatu kejahatan. Jadi kalau kita ingin menguuraikan dan mencegah kejahatan harus memperhatikan dan memahami korban suatu kejahatan, akan tetapi kebanyakan pandangan para penegak hukum itu sendiri hanya cenderung memperhatiaka pihak pelaku kejahatan, namun hakhak korban selalu terabaikan karena pandangan hukumnya korban telah diwakilkan oleh negara. Berbagai perhatian korban banyak dikemukakan oleh para ahli hukum 
pidana maupun bersumber dari konvesi-konvesi internasional yang membahas mengenai korban kejahatan, oleh karena itu secara tegas Undang-Undang telah memberikan ruang bahwa dalam suatu peradilan pidana pihak-pihak yang berperan adalah penuntut umum, hakim, terdakwa, dan penasehat hukum serta saksi-saksi. Pihak korban diwakili oleh penuntut umum sebagaimana ketentuan dalam KUHAP Pasal 50 s/d Pasal 68, dan untuk menguatkan pembuktian, lazimnya yang bersangkutan dijadikan saksi (korban) dalam suatu tindak pidana sebagiamana dugaan yang menjadikan tersangka untuk dihadapkan kemeja persidangan untuk mempertanggung jawabkan segala perbuatan yang dilakukan.

Dalam suatu pembelajaran Viktimologi yang harus kita pahami yaitu Pengabaian korban (Victim), dimana hal tersebut peritiwa yang selalu terjadi adalah pada tahap-tahap penyidikan, penuntutan, pemeriksaan di pengadilan, dan proses-proses selanjutnya.

\subsection{Sejarah Viktimologi}

Sebagaimana layaknya suatu buku yang mengupas tentang suatu bidang ilmu maka pada permulaannya perlu dikemukakan suatu pengertian-pengertian, konsepkonsep maupun definisi-definisi. Setidak-tidaknya berfungsi sebagai batasan yang sekaligus bermanfaat untuk memberikan gambaran tentang kajian materi.

Viktimologi secara etimologis, berasal dari kata "Victima" (Latin) yang berarti Korban dan "Logos" (Yunani) berarti Pengetahuan atau ilmu pengetahuan tentang korban. Pengertian tersebut yang menggunakan kata "Pengetahuan" atau "Ilmu Pengetahuan" memang masih menampakkan belum adanya suatu ketegasan apakah Viktimologi itu merupakan pengetahuan atau sudah merupakan ilmu pengetahuan. Ini terjadi karena ada beberapa pihak yang berpandangan Viktimologi hanya pengetahuan dan cabang dari kriminologi, namun ada pula yang berpandangan bahwa Viktimologi sudah merupakan ilmu pengetahuan yang sejajar dengan disiplin ilmu-ilmu lainnya.

Sebagai orang yang pertamakali ${ }^{18}$ mempergunakan istilah "Victimologi" dalam kajian tentang korban adalah Beniamin Mendelshon pada Tahun 1947

\footnotetext{
18 Adhi Wibowo, Dalam Diktatnya Bahan ajar Ilmu tentang Viktimologi Fakultas Hukum Universitas Ekasakti, Tahun 2006
} 
melalui sebuah artikelnya “ New-Bio-Psycho-Social Horizon: Victimology”, walaupun studi tentang korban pernah dilakukan sebelumnya oleh Hans von Hentig dari Yale pada tahun 1941 melalui artikelnya tentang interaksi korban dengan pelaku, namun Hentig belum memakai istilah "Victimilogi". Dengan melihat reputasinya serta perhatian yang konsisten terhadap Victimologi ini maka Mendelsohn orang Israel yang Lahir di Rumania oleh dunia internasional juga dianggap sebagai bapak pendiri (founding father) viktimologi.

Pada pertengahan abad 20 ini melihat kajian Viktimologi dapat dikatakan bahwa Viktimologi sebagai kajian yang relative baru. Dalam perkembangan berbagai disiplin ilmu selanjutnya dunia internasional cukup menggembirakan dengan lahirnya ilmu tentang Viktimologi ini dapat dilihat dari hal-hal yang penting sebagaimana pandangan dari para ahli hukum tersebut dibawah ini:

1937 Beniamin Meldelsohn menulis artikelnya mengenai kepribadian korban.

1941 Hans Von Hentig menulis sebuah artikel tentang interaksi korban dengan penjahat.

1947 Beniamin Mendelsohn menciptakan istilah Viktimologi di dalam sebuah artikel.

1957 Pembaharu Peradilan Pidana Inggris Margery Fry mendorong diskusi dan perdebatan tentang bagaimana cara memberikan ganti rugi kepada para korban.

1958 Marvin Wolfgang memberi keterangan tentang pembunuhan yang dipercepat oleh korban.

1968 Stephen Schafer menulis litaratur pertama tentang korban.

1973 Simposium Internasional Pertama tentang Viktimologi di selenggarakan di Yerusalem.

1975 Institut Studi Internasional untuk Viktimologi diselenggarakan di Bellagio, Italia. Organisasi Nasional untuk menolong korban didirikan.

1976 Simposium Internasional kedua tentang Viktimologi diselenggarakan di Boston. Viktimologi : Sebuah Jurnal Internasional mulai diterbitkan. 
1979 Simposium Internasional ketiga tentang Viktimologi diselenggarakan di Munster, Jerman Barat. Perhimpunan Viktimologi Sedunia didirikan.

1982 Institut Studi Internasional tentang Viktimologi diselenggarakan di Bellagia, Italia. Simposium Internasional keempat tentang Viktimologi diselenggarakan di Tokyo

1983 Task Force Predisen tentang korban mempelajari masalah-malasah dan menyarankan perubahan dalam undang-undang dan dalam undangundang federal dan Negara bagian guna menjamin hak-hak korban.

1984 Kuliah Pascasarjana pertama tentang korban dalam Sistem Peradilan Pidana diselenggarakan di pusat universitas untuk studi pascasarjana di Dubrovnik, Yugoslavia. ${ }^{19}$ Konperensi Internasinalegional tentang hak-hak korbanldiselenggarakan di Ottawa, Kanada dalam persiapan untuk Konggres PBB tentang Pencegahan dan Perlakuan terhadap Pelangar yang diselenggarakan di Milan, Italia. Magna Charta pertama untuk Korban Kejahatan dirancang.

1985 Kuliah Tingkat Sarjana Kedua tentang korban dalam Sistim Peradilan Pidana, Dubrovnik, Yugoslavia. Simposium Internasional Kelima tentang Viktimologi diselenggarakan di Zagreb, Yugoslavia.

\section{a. Kedudukan Viktimologi}

Kedudukan Viktimologi menurut Separovic mengemukakan dasar pembedaanya untuk dapat mengatakan Viktimologi sebagai suatu disiplin tersendiri ataukah hanya merupakan bagian dari disiplin lain. Dasar pembedaanya terletak pada ruang lingkup kajian. Apabila yang menjadi Obyek Viktimologi hanyalah korban akibat kejahatan saja, maka Viktimologi hanya sebagian dari kajian masalah kejahatan, dan sebagai akibatnya menjadi bagian dari kriminologi. Pendukung utama dari pendapat ini adalah Schneider, dan kriminologi lainnya. Namun apabila yang menjadi objek Viktimologi meliputi semua korban, termasuk pula korban bencana alam maka Viktimologi merupakan suatu disiplin ilmu tersendiri. Pendukung pandangan ini adalah Mendelsohn.

\footnotetext{
${ }^{19}$ Ibid
} 
Nagel seorang Krimonologi yang berpendirian Viktimologi sebagai bagian Kriminologi mencoba memberikan penjelasan tentang kedudukan Viktimologi. Apabila Kriminologi tetap berpegang sebagai suatu ilmu pengetahuan tentang kejahatan, berarti konsep Kriminologi yang demikian itu sangat sempit hanya mengkaji klasik. Kriminologi dalam arti etiologi kriminal, dengan tegas tidak dapat disetujui, sebab hanya mempelajari penjahatnya berarti merupakan ilmu pengetahuan yang sempit dan berat sebelah. Dalam hal yang demikian objek kriminologi tidak sesuai dengan kenyataan, bahwa kejahatan di samping penjahat terdapat korban (Separovic, 1985)

Namun demikian dapat pula dikemukakan suatu pendapat bahwa Viktimologi sebagai suatu disiplin ilmu pengetahuan yang mandiri. Pendapat tersebut dikemukakan oleh Iswanto (1995) dalam disertasinya, Pandangan tersebut didasarkan atas pendapat pakar hukum pidana, kriminologi serta symposium.

Pendapat Schafer (1968) mengatakan sebagai berikut:

" The current interest in the criminal-victim relationship indicates that the understanding of crime is entering a new phase, and may mean the decline of the objective responsibility of the offender. This aspect of the crime problem rejects the increasing recognition that criminals as members of their total group including the victim. The study of criminal relationship emphasizes the need to recognize the role and responsibility of the victim, who is not simply the cause of and reason for the criminal procedure, but has a major part to play in the search fot an objective criminal justice and a functional solution to the crime problem". "Victimology" also claims that offender has responsibility for the reparation of any harm, injury or ther disadvantage caused to his victim".

Arti pendapat Schafer (1968) di atas: "Minat saat ini dalam hubungan kriminal-korban menunjukan bahwa pemahaman tentang kejahatan ini memasuki tahap baru, dan dapat berarti penurunan tanggungjawab tujuan pelaku. Aspek Masalah kejahatan menolak peningkatan pengakuan bahwa penjahat sebagai anggota total kelompok mereka termasuk korban. studi tentang hubungan kriminal menekankan kebutuhan untuk mengakui peran dan tanggung jawab korban, yang bukan hanya penyebab dan alasan acara pidana, namun memiliki bagian besar untuk bermain dalam foto pencarian sebuah peradilan pidana obyektif 
dan solusi fungsional bagi atau untuk masalah kejahatan."Viktimologi" juga mengklaim yang pelaku memiliki tanggung jawab atas perbaikan kelemahan dari setiap kerugian, cedera atau menyebabkan korbannya".

Berdasarkan uraian Schafer tersebut di atas, dapat dipahami bahwa Viktimologi sebagai suatu disiplin ilmu pengetahuan yang mandiri mendasarkan pada antar hubungan pembuat dan korban kejahatan menekankn pada pengakuan terhadap peranan dan tanggungjawab korban bukan hanya sebagai saksi korban dalam peradilan pidana akan tetapi merupakan bagian utama serta suatu pemecahan ${ }^{20}$ fungsional terhadap masalah kejahatan dalam peradilan pidana. Selain itu viktimologi menuntut agar supaya pembuat kejahatan bertanggung jawab terhadap kerugian fisik, moril maupun nyawa korban, oleh karena itu Viktimologi dapat dijadikan dasar politik criminal pada umumnya dan untuk memecahkan masalah ketidak seimbangan perhatian dan perlakuan terhadap korban dan keluarganya dan pembuat pada khususnya.

Simposium Internasional Pertama Tentang Viktimologi Jerusalem yang diadakan pada tahun 1973 anta lain menyimpulkan bahwa:

1. Viktimologi dirumuskan sebagai suatu studi ilmiah mengenai korban

2. Kriminologi telah dipercaya dengan suatu orientasi viktimologi (Gosita, 1977)

Seminar Kriminologi VI di Universitas Diponogoro Semarang dari tanggal 16-18 September 1991, secara tidak langsung telah mengakui eksistensi viktimologi atau "criminal-victim relationship" dengan penjelasan sebagai berikut.

“...bahwa database statistic criminal yang merupakan seperangkat hasil analisis data mengenai kejahatan yang merupakan hal-hal yang berkaitan langsung dengan peristiwa kejahatan yaitu;

1. Bentuk tindak pidana yang meliputi:

a) aturan pidana yang dilanggar dan ancaman pidananya,

b) waktu dan tempat tindak pidana;

2. Pelaku tindak pidana termasuk:

20 Ibid 
a) biodata,

b) hubungan keluarga dengan korban;

3. Penyelesaian perkara; dan

4. Korban tindak pidana (Harkristuti, 1991 ; Susanto, 1991)

Dengan uraian hal-hal tersebut di atas maka jelas dapat dikatakan bahwa viktimologi telah diakui sebagai disiplin ilmu pengetahuan yang mandiri sederajat dengan disiplin lain. Dalam mempelajari Viktimologi tidak terlepas dari Sistim hukum sebagai bagian sistim Norma, karena dalam kehidupan manusia merupakan anugrah Tuhan Yang maha Esa yang harus dijalani oleh setiap manusia berdasarkan aturan kehidupan yang lazim disebut sebagai Norma.

Norma adalah istilah yang sering digunakan untuk menyebut segala sesuatu yang bersifat mengatur kehidupan manusia. Artinya bahwa bekerjanya sistim Norma bagi manusia adalah bagaikan pakaian hidup yang membuat manusia merasa aman dan nyaman dalam menjalani tugas hidupnya sehari hari demi kelangsungan kehidupannya yang akan datang, Dengan demikia maka Sistim norma yang berlaku di Indonesia ada 4 macam di antaranya adalah:

a. Norma Moral

b. Norma Agama

c. Norma Etika dan atau norma Sopan santun

d. Norma hukum

Keempat Norma kehidupan tersebut berjalan secara sistemik, simultan, dan komplementer bagi kehidupan manusia Artinya saling bertautan dan saling melengkapi,antara yang satu dengan yang lainnya. ${ }^{21}$

\section{b. Pengertian Korban Dalam Kajian Viktimologi}

Oleh Zvonimir-Paul Separovic (1985) Viktimologi didenifisikan sebagai ilmu yang berkaitan dengan studi terhadap korban (Victimology refers to science dealing with the study of victim).

\footnotetext{
${ }^{21}$ Ilhami Bisri, Sistim Hukum Indonesia Penerbit, PT. RajaGrafindo Persada Jakarta,2007, hlm.. 1-2.
} 
Dengan merujuk pada definisi tersebut maka yang menjadi kajian viktimologi adalah korban. Kata 'korban' itu sendiri dapat mempunyai banyak arti yang bervariasi serta berkembang sehingga dapat pula memberi makna yang beragam.

Dalam Webster misalnya korban dapar diartikan sebagai :

a. Suatu makhluk hidup yang dikorbankan kepada dewa atau dalam melaksanakan upacara agama;

b. Seseorang yang dibunuh, dianiaya, atau didenda oleh orang lain; seseorang yang mengalami penindasan, kerugian, atau penderitaan;

c. Seseorang yang mengalami kematian, atau luka-luka dalam berusaha menyelamatkan diri;

d. Seseorang yang diperdaya, ditipu, atau mengalami penderitaan; seseorang yang diperkejaan atau dimanfaatkan secara sewenang-wenang dan tidak layak.

Bahasa Hebrew (Yahudi) dalam Kamusnya (Even Schoschan Yerusalem, 1969. Vol. VI, Halaman 2399) mencotohkan pengertian korban antara lain: sebuah pengorbanan pribadi, yaitu "seseorang yang mati dalam sebuah kecelakaan atau kecelakaan umum”, "korban dari persengkokolannya sendiri”, “ korban perang", "korban dari gerakan kebebasan" "korban dari serangan", “ seorang yang menderita", "korban penipuan". Dalam Kamus Petit Laraousse (Paris, 1965:1100), "seorang korban adalah seseorang yang secara sukarela menyerahkan hidup dan kebahagiaana","seseorang yang menderita karena kesalahan orang lain atau kesalahannya sendiri". Kamus de la Langue Francaise dari P. Robert (Paris, 1946:985) menambahkan pengertian korban : "seseorang yang mati dalam suatu bencana atau karena penyakit, atau dalam kecelakaan, pemberontakan, atau perang".

Dalam Kamus Umum Bahasa Indonesia dari Poerwaraminta (1983) mengartikan korban sebagai:

(1) pemberian untuk menyatakan kebaktian (kerelaan hati dsb); 
(2) orang yang menderita kecelakaan karena perbuatan (hawa nafsu dsb.) sendiri atau orang lain, misalnya banyak orang yang menjadi korban roulette;

(3) orang yang mati

(4) orang yang mati karena menderita kecelakaan, karena tertimpa bencana alam seperti banjir, gempa bumi, dsb.

\section{Stanciu berpendapat sebagai berikut:}

" The victim, in the broad sense, is he who suffer unjustly (from the latin Victime, which signifies the creature offered in sacrifice to the gods). Thus, the two characteristic traits of the victim are suffering and injustice..." Artinya (makna): "Korban, dalam arti luas, adalah dia yang menderita secara tidak adil (dari latin Victime, yang berarti makhluk yang ditawarkan dalam pengorbanan kepada para dewa). Dengan demikian, dua karakteristik dari korban adalah penderitaan dan ketidakadilan ..."

Separovic (1985) memberikan pengertian korban sebagai berikut.

“... A victim is considered as anyone, physical or moral person, who suffers either as a result of ruthless design, incidentally, or accidentally”. Artinya (makna): "... Korban dianggap sebagai orang, orang fisik atau moral, yang menderita baik sebagai akibat dari desain kejam, kebetulan, atau tanpa sengaja".

Pengertian korban tersebut di atas berdasarkan maknanya pada hakikatnya dapat dikategorikan menjadi dua (2):

Pertama korban dalam arti "sacrifice" artinya bentuk korban (pengorbanan) yang dikaitkan dengan hal-hal yang bersifat metafisik, supranatural, misalnya korban dalam upacara keagamaan dan atau sejenisnya.

Pengertian korban yang kedua adalah "korban" secara keilmuan (victimological). Dalam pengertian kedua ini meliputi semua bentuk korban yang tidak termasuk dalam pengertian korban yang pertama. Pengertian korban secara victimologis ini dapat diperjelas dengan melihat pendapat Iswanto 1995,), (bahwa korban merupakan akibat perbuatan atau kelalaian, kemauan suka rela atau dipaksa atau ditipu, bencana alam, dan semuanya benar-benar berisi sifat penderitaan jiwa, raga, harta dan morel serta sifat ketidakadilan. 
Kajian terhadap korban saat ini cenderung tidak berkaitan dengan pengertian korban dalam konsep pertama yang bersifat "sacrificak". Namun demikian pengertian ini dalam sejarah nampaknya sempat mendapat perhatian pula, karena hamper setiap masyarakat di manapun pernah mengeal ataupun melakukannya. Seperti halnya di Yugoslavia terdapat kata "ZRTVA" dari bahasa Serbo-Kroasia yang berarti korban, berdasarkan sejarah etiologi, mitologi, menurut old church Slavonic istilah itu menunjukan pemberian suatu benda (pemberian nazar) kepada para dewa, pahlawan, atau nenek moyang dengan tujuan penghormatan dari seseorang sebagai ungkapan akan pengakuan atas adanya kekuasaan, minta pengampunan dan lainya. Bentuk pengorbanan tersebut mempunyai unsure utama berupa pengrusakan guna menuju kesucian yang bersifat sakral. Korban ini dapat pula diartikan sebagai persembahan kepada kekuatan magis dari ruh-ruh alam terutama terhadap tanaman, binatang serta nenek moyang yang dianggap sebagai pahlawan.

Pengorbanan sering bertujuan sebagai ungkapan rasa terimakasaih kepada dewa dan memohon pertolongan lebih lanjut, misalnya untuk keberhasilan bercocok tanam serta beternak agar mendapat panen atau hasil yang banyak. Pemberian korban sering juga dilakukan sebagai penebusan dosa yang telah diperbuat sebagai upaya untuk membersihkan diri. Hal ini terutama dilakukan misalnya pada malam menjelang peristiwa penting seperti berbutu atau pertempuran, maupun sedang dilanda bencana besar seperti banjir, gempa bumi, atau bila da wabah penyakit. Persembahan korban ini dibuat agar para dewa menjadi belas kasihan terhadap pada pengorban. Persembahan ini dikenal dengan persembahan "propitiatory".

Persembahan korban tidak mesti melibatkan darah, akan tetapi misalnya dapar berupa gandum, hasil panen, minyak, anggur (disajikan, ditumpahkan atau dikonsumsi), bunga-bunga dan tanaman yang aromatic seperti kemenyan atau tembakau yang mengeluarkan bau-bauan yang kuat ketika dibakar, dan yang paling sering adalah hewan yang dibakar seutuhnya. Ini dinamakan persembahan pembakaran atau "holocaust". Dan untuk persebahan yang bagian misalnya 
ususnya saja sedang dagingnya dimakan bersama di sebut sebagai persembahan komuni.

Orang jawa pada umumnya juga sebenarnya sudah mengal tradisi pemberian korban sejak jaman dahulu yang kurang lebih mempunyai tujuan yang sama dengan bentuk pengorbanan tersebut di atas. Dimasyarakat Banyumas misalnya menggunakan istilah "sajen" atau masyarakat jawa timur dengan upacara "Kesodo" yang dilakukan di kawah Gunung Bromo.

Ada pula bangsa yang mempunyai tradisi pengorbanan manusia seperti di Indiean, Yunani, suku-suku Jerman, Kelt, Slav dan lain.lain. Dalam hal ini yang sering dikorbankan adalah para narapidana dan anak-anak dimana dalam perngorbanan tersebut yang paling dihargai adalah jantung manusia.

Kembali pada permasalahan kajian viktimologi berupa korban maka yang dimaksud di korban sini adalah korban dalam konsep keilmuan (victimological). Termasuk didalamnya antara lain korban akibat dari kejahatan atau perbuatan yang dapat dihukum (victim of crime), korban kecelakaan (victim of accident), korban kecelakaan (victim of accident), korban bencana alam (victim of natural disaster), korban kesewenang-wenangan penguasa atau korban atas pelenggaraan hak asasi manusia (victim of illegal abuses of public power) maupun korban dari penyalahgunaan kekuasaan di bidang ekonomi (victim of illegal abuses of economic).

\section{c. Jenis Korban Dalam Masyarakat}

Viktimologi merupakan suatu studi atau pengetahuan ilmiah yang mempelajari masalah korban criminal sebagai suatu masalah manusia yang merupakan suatu kenyataan sosial. Dan viktimologi merupakan bagian dari kriminologi yang memiliki obyek study yang sama yaitu kejahatan dan korban criminal (viktimisasi criminal).

Korban yang dapat mengakibatkan kerugian dan atau penderitaan baik secara fisik maupun prikologis, dalam masyarakat, berdasarkan kriterium obyek yang menderita oleh separovic diklasifikasikan menjadi empat yaitu:

a) Korban individual; 
b) Korban kolektif;

c) korban abstrak; dan

d) korban pada diri sendiri (pribadi).

Untuk itu penulis menjelaskan mengenai arti penting dari pada Korban Individual, Kolektif, Abstrak dan Korban pada diri sendiri termasuk dalam lingkungan keluarga yang banyak menimbulkan permasalahan yang mendasar terkait dengan adanya Korban kekerasan dalam rumah tangga (KDRT), dan penjelasan tersebut adalah sebagai berikut:

a) Korban individual adalah korban diderita oleh seseorang secara individu, misalnya seorang yang mati karena pembunuhan, seorang yang diperkosa, dianiaya, diperdaya, ditipu dsb

b) Korban kolektif, adalah korban yang dialami oleh beberapa individu secara bersama baik dari satu kelompok maupun bukan. Korban kolektif misalnya korban pembantaian dengan tujuan pemusnahan suatu suku bangsa atau teknik tertentu (genocide), korban dari perang antar golongan. Di dunia internasional jenis korban semacam ini terjadi contohnya pada suku Hutu maupun Tutsi di Rwanda Afrika. Termasuk pula dalam jenis korban kolektif adalah kerugian konsumen atas suatu produk perusahaan. Contoh korban ini adalah tragedy Thalidomide (Thalidomide Affair), yang mengakibatkan ratusan bayi lahir cacat akibat ibunya sewaktu mengandung mengkonsumsi suatu obat dengan merek dagang Distavel yang dipropagandakan dapat melindungi bayi yang sedang dikandung.

c) Korban Abstrak, adalah jenis korban yang sulit untuk dilihat secara jelas bahwa seseorang menjadi korban. Contoh dari korban abstrak adalah korban kejahatan dan pelanggaran terhadap ketertiban umum, misalnya: mengendarai motor dalam keadaan mabuk karena pengaruh alkhohol, eshibisionisme, memiliki barang curian dsb.

d) Korban pada diri sendiri, adalah korban yang terjadi pada suatu jenis kejahatan yang dalam literature sering disebut dengan "kejahatan tanpa korban" (crime without victim). Sebenarnya kejahatan ini ada korbannya. Namun yang menjadi korban adalah para pelakunya sendiri, maka seolah- 
olah tidak ada korban. Contah jenis ini adalah korban aborsi, homoseksual, pecandu obat (drug addition), judi, dan bunuh diri.

e) Korban akibat kekerasan dalam Rumah tanggan sebenarnya bukan hal yang biasa akan tetapi sejak lama sudah terjadi namun selalu di tutup tutupi oleh korban dan pelaku itu sendiri apalagi terjadi dalam lingkungan rumah tangga itu sendiri dimana hal tersebut mengandung sesuatu yang spesifik atau khusus, yakni terlatak pada hubungan antara pelaku dan korban, yaitu hubungan kekeluargaan atau hubungan pekerjaan (majikanpembantu rumah tangga). Selain itu, locus delicti pada kekerasan dalam rumah tangga lebih spesifik, yaitu di dalam rumah, di mana pelaku dan korban bertempat tinggal, sedangkan pada tindak pidana yang lain, locus delicti bisa di mana saja, di semua tempat. Undang-undang Nomor 23 Tahun 2004 tentang Penghapusan Kekerasan Dalam Rumah Tangga, merupakan "payung hukum" bagi para korban tindak kekerasan dalam rumah tangga. Menurut Undang-undang nomor 23 Tahun 2004 Pasal 1 ayat (1) yang dimaksud dengan kekerasan dalam rumah tangga adalah: Setiap perbuatan terhadap seseorang terutama perempuan, yang berakibat timbulnya kesengsaraan atau penderitaan secara fisik, psikologis dan/atau penelataran rumah tangga termasuk ancaman untuk melakukan perbuatan, pemaksaan atau perampasan kemerdekaan secara melawan hukum dalang lingkup rumah tangga. Dalam bahasa Inggris: Every action against a person, especially women, resulting in the emergence of misery or suffering physically, psychologically and / or penelataran household including threat to commit acts, coercion or deprivation of liberty unlawfully mastermind domestic sphere.

Buku ini menelaah secara komprehensif Kekerasan Dalam Rumah Tangga (KDRT) dalam prespektif yuridis-viktimologis meliputi:Fenomena tindak kekerasan dalam masyarakat dan terhadap perempuan; upaya penanganan kasus KDRT berdasarkan KUHP dan UU No. 23 Tahun 2004; kedudukan dan peranan perempuan dalam hukum masyarakat; kekerasan dalam rumah tangga; faktor pendorong dan bentuk-bentuk tindak KDRT; KDRT dalam perspektif hukum dan 
HAM; korban KDRT; kasus-kasus KDRT; upaya menanggulangi hambatan penanganan kasus KDRT melalui jaringan kerja sama; analisis berbagai undangundang yang berkaitan dengan KDRT. ${ }^{22}$

Beberapa hal yang sangat sitnifikan dalam penanggulangan Korban Kekerasan Rumah Tangga, yang sangat diperlukan adalah uraian serta penjelasan yang akurat agar tidak ada ketimpangan dalam suartu pengertian yang lebih akurat terhadap peristiwa yang akan dibahas, untuk itu penulis membahas tentang problematiaka tindak kekerasan terhadap perempuan yang dikutip dalam buku Moerti Hadiati Soeroso, yaitu; Tindak kekerasan terhadap perempuan adalah masala bersama yang tidak dapat diputuskan tali rantai antara satu pihak dengan pihak lain. Oleh karena itu, masyarakat dan juga Negara perlu disadarkan, didesak, dituntut dan diawasi untuk serta bertanggung jawab dalam memerangi kekerasan terhadap perempuan serta kekerasan berdasarkan jenis kelamin.

Secara umum kekerasan terhadap perempuan telah diatur dalam Kitab Undang-Undang Hukum Pidana (KUHP), dibawah bab tentang kejahatan terhadap kesusilaan. Misalnya; pemorkosaan terhadap perempuan yang bukan istrinya sebagaimana telah diatur dalam Pasal 285 KUHP, diancam karena melakukan pemorkosaan dengan penjara paling lama duablas tahun. Pasal 286 KUHP memberikan penjelasan bahwa, Barang siapa bersetubuh dengan seorang wanita diluar perkawinan padahal diketahui bahwa wanita itu dalam keadaan pinsan atau tidak berdaya, diancam dengan penjara paling lama Sembilan tahun. Sedangkan dalam Pasal 287 ayat (1) KUHP menjelaskan bahwa, barang siapa bersetubuh dengan seorang wanita diluar perkawinan, padahal diketahuinya atau sepatutnya harus diduganya bahwa umurnya belum limabelas tahun, atau kalau umurnya tidak jelas, bahwa waktunya belum untuk kawin, diancam dengan pidana penjara paling lama Sembilan tahun. Pasal 288 ayat (1) KUHP, barang siapa dalam perkawinan bersetubu bersetubuh dengan seorang wanita yang di ketahuinya atau sepatutnya harus diduganya bahwa yang bersangkuatan belum waktunya untuk kawin, apabila perbuatan mengakibatkan luka-luka diancam dengan pidana penjara paling lama empat tahun, sedang dalam dalam Pasal 288 ayat (2) KUHP menjelaskan bahwa

\footnotetext{
22 Moerti Hadiati Soeroso, Kekerasan Dalam Rumah Tangga Dalam Perspektif Yuridis-Viktimologis Penerbit Sinar Grafika, Jakarta 2010. hlm. 29.
} 
jika perbuatan mengakibatkan luka-luka berat dijatuhkan pidana penjara paling lama delapan tahun, dan dalam Pasal 288 ayat (3) KUHP memberkan penjelasan bahwa jika perbuatan tersebut dapat mengakibatkan mati, diancam dengan penjara paling lama duablas tahun. Pasal 294 ayat (1) KUHP menjelaskan bahwa; barang siapa melakukan perbuatan cabul dengan anaknya, anak tirinya, anak angkatnya, anak dibawah pengawasannya yang belum dewasa yang pemeliharaanya, pendidikan atau penjagaannya diserahkan kepadanya atau dengan bujangannya atau bawahannya yang belum dewasa, diancam dengan penjara paling lama tujuh tahun. Pasal 297 KUHP menjelaskan bahwa perdagangan anak wanita dan anak laki-laki yang belum dewasa atau masih dibawah umur, yang mana hal tersebut diatas anakanak baik itu anak laki-laki ataupun anak perempuan masih membutuhkan bimbingan, perlindungan, baik moral, etika, pendidikan, maka diancam dengan pidana penjara paling lama enam tahun. Pada Pasal 356 KUHP tentang penganiyaan terhap istri yang mana hal tersebut ancama pidananya telah dijelaskan dalam Pasal 351, 352, 353, 354, 355. Yaitu ancaman pidananya disesuaikan dengan perbuatan yang dilakukan oleh pelaku tindak pidana tersebut sebagai mana telah ditentukan sebelumnya oleh Kitab Undang-Undang Hukum Pidana (KUHP). ${ }^{23}$ Dalam penganiyaan terhadap istri (domestic violence) Kitab Undang-Undang Hukum Pidana memberikan pemberatan hukuman, namun Kitab Undang-Undang Hukum Pidana tidak mengaturnya dalam bab atau pasal tersendiri, melainkan sebagai bagian dari pasal Pasal penganiyaan terhadap anggota keluarga. Selain itu, Kitab Undang-Undang Hukum Pidana hanya mengakui kekerasan fisik sebagai bentuk kejahatan, tidak mempertimbangkan kekerasan psikis atau seksual.

Perlu disadari bahwa hukum pidana bukan satu-satunya strategi dapat mempengaruhi masalah penghapuskan kekerasan dalam rumah tangga, terhadap perempuan. Bagaimanapun juga struktur dan tradisi dalam suatu Negara dapat mempengaruhi bentuk dan sikap terhadap perempuan dan tindak pidana kekerasan yang dialami atau diderita. Dan tidak dapat dipungkiri bahwa dalam kehidupan sehari hari pihak aparat penegak hukum masih kurang perduli terhadap masalah tindak kekerasan terhap perempuan amaupun kekerasan dalam rumah tangga. Dan

\footnotetext{
${ }^{23}$ Moelyatno, Kitab Undang-Undang Hukum Pidana. Penerbit Bumi Aksara. Jakarta. Tahun 2003, hlm. 105-107-109-126.
} 
tindakan tersebut selalu tidak ditempatkan sebag bukan kejahatan (real craime) seperti perampokan, pembunuhan dan lain-lainnya.

Akhir-akhir ini kekerasan dalam rumah tangga, kekerasan terhap perempuan, kekerasan terhadap anak, baik itu terhadap anak laki-laki dan anak perempuan baik masih anak-anak, telah remaja maupun dewasa, ini adalah merupakan pembuktian yang nyata terhadap kurangnya pengawasan maupun sosialisai daripada para penegak hukum, yang mana hal-hal yang demikianlah adalah merupakan tanggung jawab kita bersama agar tidak terjadi peristiwa pidana yang tidak kita sama inginkan. Namun disatu sisi kekerasan terhadap perempuan adalah merupakan perhatian yang serius karena mempunyai dampak yang luas, besar tehadap kaum perempuan khususnya dilingkungan masyarakat pada umumnya. Kekerasan yang sejenis ini mempunyai akar yang dalam pada faktor budaya yang menempatkan perempuan pada posisi yang timpang atau selalu dianggap lemah dalam hubungannya dengan laki-laki. Hal yang demikian telah diakui oleh masyarakat pada umumnya, baik dalam negeri maupun luar negeri, baik nasional maupun internasional, sebagai mana telah dikemukakan dalam Deklarasi Perserikatan Bangsa-Bangsa (PBB) terhadap penghapusan kekerasan terhadap perempuan (selanjutnya akan disebut sebagai Deklarasi Kekerasan).

\section{d. Pembagian Viktimologi}

Menurut Separovic (1985) yang mensitir pendapat R.Elias dalam bukunya Transceding our social Reality of victimization: Toward a New Viktimology of Human Right, Lisbon, 1984, membagi Viktimologi menjadi tiga (3) bagian antara lain:

1. Viktimologi dalam arti sempit, adalah suatu ilmu pengetahuan empiris yang berkaitan dengan korban dari kejahatan atau perbuatan yang dapat dihukum. Viktimologi dalam arti ini juga dapat disebut juga sebagai viktimologi Penal, Viktimologi criminal atau viktimologi khusus Contohnya antara lain adalah: dari obyek Viktimologi dalam arti sempit adalah Korban carok, Korban "Vendeta”(korban kejahatan), Korban tindak pidana pemorkosaan, Korban tindak pidana pencurian, Korban 
tindak pidana pembunuhan, Korban tindak pidana penculikan (korban dari suatu perbuatan yang dapat dihukum/perbuatan yang diatur dalam kitab undang-undanh hukum pidana).

2. Viktimologi dalam arti luas, adalah mencakup seluruh ilmu pengetahuan tentang korban pada umumnya, termasuk dalam lingkup ini adalah korban dari perbuatan yang dapat dihukum yaitu akibat kelalaian menimbulkan kecelakaan, korban akibat dari perbuatan atau tingkah laku yang dilakukan di tengah-tengah masyarakat, korban dari Negara atau korban kolompok masyarakat yang representatif. Untuk itu Penulis memberikan beberapa contoh korban dari perbuatan baik disengaja maupun tidak disengaja yang meliputi berbagai macam antara lain:

a) Korban kecelakaan lalulintas

b) Korban kecelakaan kerja

c) Korban akibat bencana alam, korban korupsi, korban kejahatan bisnis, korban pencucian uang, korban pemorkosaan, korban kekerasan dalam rumah tangga.

3. Viktimologi barau adalah ilmu pengetahuan tentang korban yang mencakup koban- korban penyalagunaan kekuasaan dan pelanggaran terhadap hak asasi manusia, dan korban yang dimaksud oleh kriminologi radikal adalah korban korban kejahatan konvesional dan koban tindak pidana yang dilakukan oleh kelas yang berkuasa terhadap kelas yang kurang mampu. Namun demikian yang paling menonjol dalam Viktimologi baru ini adalah korban dari pelanggaran hak asasi manusia sebagai hak yang mempunyai nilai universal serta direkomondasikan oleh perserikatan Bangsa-Bangsa agar dihormati oleh seluruh bangsa-bangsa didunia yang merasa dirinya bangsa yang beradab.

Ketiga korban tersebut diatas dalam ilmu Viktimologi disebut juga sebagai Viktimologi Umum (general viktimology). 
Dalam buku ini penulis akan memberikan beberapa hal tentang pandangan mengenai pentingnya perlindungan atas korban dalam pelanggaran hak asai manusia (HAM) berat dalam hukum positif dan hukum internasional dalam pemberian kompensasi dan restitusi (Compesation And Restitution). Perlindungan korban kejahatan dalam system hukum nasional nampaknya belum memperoleh perhatian yang serius. Hal ini masih terlihat sedikitnya hak-hak korban kejahatan memperoleh pengaturan dalam perundang-undangan nasional, yang mana hal tersebut terlihat adanya ketidak seimbangan antara perlindungan korban kejahatan dengan pelakun kejahatan pada dasarnya merupakan salah satu pengingkaran dari asas setiap warga Negara bersamaan kedudukannya dalam hukum dan pemerintahan sebagaimana diamanatkan dalam Pembukaan Undang-undang Dasar Negara Republik Indonesia Tahun 1945 sebagai landasan Konstitusional. Yang mana selama ini bermunculan pandangan dari beberapa pendapat para ahli hukum yang menyebutkan bahwa pada saat pelaku kejahatan telah diperiksa, diadili dan dijatuhi hukuman pidana, maka pada saat itu perlindungan terhadap korban telah diberikan, namun penulis berpendapat lain bahwa tidaklah sepenuhnya benar korban mendapatkan perlindungan sebagaimana yang di harapkan, namun penulis dengan menggunakan teori keseimbangan maka perlindungan yang sepenunya hanyalah kepada pelaku kehatan semata, sedangkan korban dari suatu tindak pidana terbaikan (tidak sepenuhnya).

Deklarasi Perserikatan Bangsa-Bangsa (PBB) tentang korban kejahatan dan korban penyalahgunaan kekuasan yang dirumuskan dalam The Declaration of Basic Principles of Justice for Victims of Crime on Abuse of Power (Resolution General Assembly United Nation No. 40/34 Tahun 1985) sebagai berikut.

\section{(1) Victim Of Crime}

a. Victims means person who, individually or collectively, have suffered harm, including physical or mental injury, emorional suffering, economic loss or substantial impairment of their fundamental rights, through acts or omissions that are in violation of criminal laws operative wthin Member states, including those laws proscribing criminal abus of power. Artinya(makna): Korban berarti orang yang secara individu atau kolektif, 
telah menderita kerugian, termasuk luka fisik atau mental, penderitaan emorional, kerugian ekonomi atau penurunan substansial dari hak-hak fundamental mereka, melalui tindakan atau kelalaian yang melanggar hukum pidana negara Anggota wthin operasi, termasuk hukum proscribing abus pidana kekuasaan.

b. A person may considered a victim, under this Declaration regardless of whether, the perpetrator is identified, apprehended, prosecuted or convicten and regardless of the familiar relationship between the perpetrator and the victim. The term "victim" also includes, where appropriate, the immediate family of defendants of the direct victim and person who have suffered harm in intervening to assist victims in distress or to prevent victimization. Artinya (makna): Seseorang mungkin dianggap korban, di bawah Deklarasi ini terlepas dari apakah, pelaku yang diidentifikasi, ditangkap, diadili atau convicten dan terlepas dari hubungan akrab antara pelaku dan korban. "Korban" Istilah juga termasuk, bila sesuai, keluarga langsung terdakwa dari korban langsung dan orang yang telah menderita kerugian memutuskan untuk mendampingi korban dalam kesusahan atau mencegah jatuhnya korban.

c. The provisions contained here in shall be applicable to all, without distinction of any kind, such as race, color, sex, age, language, religion, nationality, political or other opinion, cultural beliefs or pracrices property, birth or family status, ethnic or social origin, and disability (Separovic, 1988). Artinya (makna): Ketentuan yang terkandung di sini di berlaku untuk semua, tanpa pembedaan apapun, seperti ras, warna kulit, jenis kelamin, umur, bahasa, agama, kebangsaan, pendapat politik atau lainnya, kepercayaan budaya atau pracrices Status kekayaan, kelahiran atau keluarga, etnis atau sosial asal, dan cacat (Separovic, 1988).

(2). Victims of abuses of power (Korban penyalahgunaan kekuasaan)

a) Victim means person who, individually or collectively, have suffered harm, including physical or mental injury, emiotional suffering, economic loss or substantial impairment of their fundamental rights, through acts or 
omission that do not yet constitute violations of national criminal laws but of internationally recognized norms relating to human rights. Artinya (makna): Korban berarti orang yang secara individu atau kolektif, telah menderita kerugian, termasuk luka fisik atau mental, penderitaan emiotional, kerugian ekonomi atau penurunan substansial dari hak-hak fundamental mereka, melalui tindakan atau kelalaian yang belum merupakan pelanggaran hukum pidana nasional, tetapi dari norma-norma yang diakui secara internasional yang berkaitan dengan hak asasi manusia.

b) States should condiser incorporating intonational law norm proscribing abuses of power and providing remedies to victim such abuses. In particular, such remedies should include restitution and/or compensation, and social assistance support. Artinya (makna): Negara seharusnya condiser menggabungkan norma hukum intonasi proscribing penyalahgunaan kekuasaan dan memberikan solusi untuk pelanggaran korban tersebut. Secara khusus, obat tersebut harus mencakup restitusi, dan/atau kompensasi, dan dukungan bantuan sosial

c) States should condiser negotiating multilateral international treaties relating to victims, as defined in paragraph 18. Artinya (makna): Negara seharusnya condiser negosiasi perjanjian internasional multilateral yang berkaitan dengan korban, sebagaimana didefinisikan dalam ayat 18.

d) States should periodically review existing legislation and practices to ensure their responsiveness to changing circumstances should enact and enforce, if necessary, legislation proscribing acts that constitute serious abuses of political or economic power, as well as promoting police and mechanisms for the prevention of such acts and should develop and make readily avaible appropriate rights and remedies for victims of such acts (Separovic, 1988). Artinya (makna): Negara harus secara berkala meninjau ulang peraturan yang ada dan praktek untuk memastikan respon mereka terhadap perubahan keadaan harus memberlakukan dan menegakkan, jika perlu, undang-undang proscribing tindakan yang merupakan pelanggaran serius dari kekuasaan politik atau ekonomi, serta 
mempromosikan polisi dan mekanisme untuk pencegahan seperti bertindak dan harus mengembangkan dan membuat hak yang tepat mudah avaible dan penyembuhan bagi korban tindakan tersebut (Separovic, 1988).

Dari ketiga pembagian viktimologi tersebut di atas dapat dikemukakan suatu perkembangan atas pembagiannya. Yang pertama adalah viktimologi khusus, namun kajian korban ini nampaknya kurang memuaskan sehingga berkembang menjadi viktimologi umum. Walaupun sudah terdapat viktimologi khusus dan umum, tetapi masih mendapat kritikan yang tajam, sehingga lahir viktimologi baru, yang melihat perlu suatu kajian korban dalam viktimologi baru. Hal ini dilandasi suatu pemikiran bahwa kriminologi dan viktimologi tradisional berjalan dari definisi tentang kejahatan yaitu seseorang yang melanggar norma. Definisi ini cenderung mempertimbangkan klas dalam hukum, karena menurut Separovic tidak ada hukum yang netral yang tidak berkelas.

Kriminologi ortodok dan juga viktimologi cenderung mengabdi kepada kepentingan Negara. Mereka dipekerjakan sebagai teknokrat, ahli dan penasihat pada pengadilan. Dalam peranannya sebagai pendukung Negara mereka melakukan perbuatan-perbuatan yang merugikan golongan pekerja, misalnya pengambil alihan angka surplus oleh para pemilik alat produksi, sama sekali berada di luar jangkauan hukum pidana dan tidak dicela sebagai pelaku tindak pidana.

Kriminologi radikal bertujuan untuk mengungkapkan suatu bahaya social atas sesuatu perbuatan sebagai kejahatan dengan menggunakan nilai-nilai norma kaum proletar (rakyat) dari pada nilai-nilai kaum borjuis (penguasa). Dari definisi kejahatan yang berangkat dari nilai-nilai moral kaum proletar ini maka sebagian besar pelaku kejahatan dari tindak pidana yang diketahui adalah golongan pekerja. Demikian pula dalam hal korban, sebagaian besar adalah mereka yang kurang mampu di dalam masyarakat.

Para pendukung kriminologi radikal menegaskan bahwa kriminologi harus bertujuan untuk menciptakan kesadaran politik mereka yang menjadi korban system kapitalisme. Oleh sebab itu moralitas proletar harus ditempatkan dalam suatu sikap revolusioner untuk mencegah penyimpangan kaum penguasa. Sebagai 
konsekuensi atas pandangan tersebut maka statistic criminal resmi tentang korbankorban dari tindak pidana semacam itu akan batal dan tidak dapat diterima sebagai kebenaran.

Dasar pemikiran lain bahwa penguasa hukum yang bertindak melalui aparataparat, telah mendefinisikan hukum lebih merupakan kepentingan klas atau kelompoknya dari pada kepentingan-kepentingan masyarakat banyak. Oleh karena itu hasil stastik criminal resmi yang ada lebih merupakan konsrtuksi hukum yang dibuat penguasa dari pada realitas social. Dengan melihat kondisi seperti itu akhirnya Separovic cenderung setuju dengan pelanggaran atas hak-hak asasi manusia yang termuat dalam konsepsi umum universal tentang hak asasi manusia yang diterima oleh masyarakat international didefinisikan sebagai tindak pidana. Dengan demikian maka akan lebih tampak sosok korban "baru" sebagai kajian viktimologi yakni korban akibat pelanggaraan hak asasi manusia yang selama ini seolah-olah "tidak ada", sebagai akibat atas tidak didefinisikan pelanggaraan hak asasi manusia sebagai tindak pidana oleg para pembuat undang-undang demi kepentingan kelompok tertentu (penguasa).

\section{e. Tujuan Viktimologi}

Sebagai salah satu ilmu yang bersifat interdisipliner viktimologi terdiri atas kumpulan pengetahuan dari berbagai disiplin antara lain kriminologi, hukum, kedokteran, psikologi, pendidikan pekerjaan social, administrasi umum, dan lainlain. Viktimologi juga mencakup berbagai bidang aktivitas yang dilakukan oleh kepolisian, kejaksaan, pengadilan, lembaga kesejahteraan social, lembaga pendidikan, perusahaan asuransi, serta lembaga perundang-undangan.

Dalam kaitannya dengan kedua batasan viktimologi tersebut di atas maka viktimologi mempunyai tiga tujuan sebagai berikut (Separovic, 1985).

a. Menganalisis berbagai aspek masalah korban (to analyze the manifold aspect of the victim's problem). Dalam tujuan untuk menganalisa berbagai aspek masalah korban ini meliputi kerugian dan/atau penderitaan korban.

b. Menjelaskan sebab-sebab terjadinya pengorbanan (to explain the causes for victimization). Hal ini meliputi suatu analisis serta penjelasan tentang 
factor-faktor yang menyebabkan timbulnya korban. Dalam kajian viktimologi akan tampak bahwa timbulnya korban tidak mutlak disebabkan oleh kesalahan pelaku kejahatan, namun dapat pula disebabkan oleh kesalahan korban dari tingkat yang ringan hingga kesalahan penuh dipihak korban

c. Menciptakan suatu system kebijakan dalam upaya untuk mengurangi penderitaan manusia (to develop a system of measures for reducing human suffering). Hal ini dapar betupa kebijakan perlindungan hukum bagi korban berupa pemberian hal dalam system peradilan pidana maupun kebijakan lain berupa restitusi dan/atau kompensasi.

Dari tujuan-tujuan tersebut muara tujuan viktimologi terletak pada tujuan ketiga. Namun dalam mencapai tujuan ketiga, tujuan yang pertama dan kedua haruslah dicapai terlebih dahulu, karena merupakan landasan bagi penyusunan tujuan ketiga.

Tujuan untuk membuat kebijakan guna mengurangi penderitaan bagi korban, oleh Mendelsohn (1985) dikatakan sebagai tujuan viktimologi yang terpenting. Argumentasinya berpijak pada suatu pemikiran bahwa semua masyarakat berkaitan dengan permasalahan tersebut. Dengan mengurangi penderitaan atau kerugian korban akan dapat lebih menberdayakan masyarakat serta menjamin kehidupannya.

\subsection{BERBAGAI ASPEK MASALAH KORBAN}

Berbagai tujuan viktimologi yang pertama sebagaimana pendapat Separovic adalah menjelaskan berbagai aspek masalah korban. Pada bab ini aspek permasalahan korban yang dibicarakan lebih dititikberatkan pada kerugian dan/atau penderitaan korban akibat tindak pidana yang menimpanya (Viktimisasi). ${ }^{24}$

Setiap pihak korban akan merasakan dampak negatif berupa kerugian dan/atau penderitaan akibat tindak pidana yang menimpanya, khsusnya korban tindak pidana kekerasan. Kerugian dan/atau penderitaan ini dapat diklasifikasikan menjadi tiga meliputi: luka fisik; kerugian materi; dan kerugian social serta psikologis. Tiga pembedaan ini tidak berarti bahwa seorang korban hanya akan

\footnotetext{
${ }^{24}$ Adhi Wibowo, op.cit.,.hlm. 17.
} 
dapat mengalami salah satu jenis kerugian dan/atau penderitaan. Pada beberapa jenis tindak pidana dapat pula dijumpai berbagai kerugian dan/atau penderitaan yang dirasakan sekaligus.

\section{Luka Fisik}

Luka fisik yang diderita korban, termasuk yang mudah terlihat dibandingkan dengan jenis penderitaan lainnya. Ini mempunyai dampak yang bervariasi sesuai dengan tingkat keseriusan luka yang diderita korban. Untuk penganiayaan ringan yang hanya menyebabkan sakit kepala, luka goresan kecil, cenderung tidak begitu dihiraukan sebagai luka fisik. Mereka akan tetap melakukan aktivitas kehidupan walaupun agak sedikit terganggu, misalnya aktivitas makan (luka pada mulut dan gigi) atau mengendarai (luka pada lengan).

Korban cenderung cenderung akan merasakan sebagai penderitaan yang serius apabila menderita luka fisik yang berat dan sangat ternganggu aktivitas kerja atau hingga tidak berfungsinya salah satu atau beberapa anggota badan dan menjadikan cacat seumur hidup. Misalnya kesulitan pendengaran, gigi yang tanggal, tangan atau kak yang tidak bisa digerakan, tidak dapat berfungsinya lagi salah satu anggota tubuh dan sebagainya.

\section{Kerugian Materi}

Tindak pidana terhadap harta kekayaan antara lain pencurian biasa, pencurian dengan kekerasan mengakibatkan kerugian bagi korban di bidang materi berupa uang dan hilangnya pendapatan yang seharusnya diperoleh maupun property lainnya. Yang dimaksud dengan property lainnya misalnya hilangnya perhiasan, sepeda motor, kaca-kaca jendela yang pecah, pintu yang dirusak, serta kerusakan barang-barang lain yang ditimbulkan atas tindak pidana yang terjadi. Di samping kerugian yang diderita saat terjadinya tindak pidana, untuk beberapa jenis tindak pidana kerugian materi masih dapat dideritanya setelah tindak pidana terjadi, berupa pengeluaran biaya transport dan akomodasi yang harus dikeluarkan selama proses penyelesaian perkara dari tahap penyelidikan hingga pemeriksaan di pengadilan saat korban diperlukan kehadirannya sebagai saksi korban. Kerugian akan dapat berlipat apabila proses penyelesaian perkara memerlukan pemeriksaan 
dan persidangan yang berulangkali serta adanya kewajiban saksi korban untuk hadir.

Kerugian materi juga bisa menyertai pada luka fisik seperti biaya pengobatan serta biaya terapi psikologis yang diderita korban akibat tindak pidana yang menimbulkan kegoncangan jiwa, misalnya korban perkosaan serta korban percobaan tindak pidana pembunuhan.

\section{Kerugian Sosial dan Psikologis}

Pengertian psikologis criminal, psikologis criminal berasal dari bahasa yunani yang terdiri dari dua suku kata, yaitu: psikiko artinaya nafas/jiwa dan logos artinya ilmu dimana hal tersebut kedua kalimat tersebut adalah ilmu tentang jiwa. Kriminal berasal dari istilsh crime artinya jahat/kejahatan. Kalau kita rangkaikan, psikologis-Kriminal berarti ilmu-jiwa-kejahatan. Selanjutnya kalau kita perhatikan defenisi-defenisi yang dikemukan oleh para psikologi ternyata bahwa psikologi mendasarkan suatu pendapat tentang adanya hubungan perbuatan dengan jiwa manusia dan pelakunnya. Misalnya pendapat Crow\& Crow, menyatakan bahwa psikologi adalah ilmu pengetahuan yang mempelajari tingka laku manusia dan berhubungan dengan kemanusiaaan. Dalam hal ini Crow bersaudara menarik kesimpulan bahwa psikologis itu merupakan pelajaran tentang diri (the study of self). Sedangkan pendapat lain dari pakar psikologis yang bernama Woodworth menyatakan pula bahwa psikologis adalah ilmu pengetahuan yang mempelajari tentang aktivitas-aktivitas dari pada individu-individu didalam hubungannya dengan lingkungan. Menurut Woodworth memberikan pengertian terhadap aktivitas itu adalahdalam pengertian luas mengcakup antara lain dalam Motoris (berjalan,berlari), cog netive (melihat, berpikir) dan emosional (a.l.bahagia, dukacita). Untuk itu dengan aktivitas-aktivitas tersebut ini adalah merupakan tanda kehidupan manusia. Maksudnya, jika aktivitas-aktivitas tersebut terhenti maka berarti dalam kehidupan itu sudah tidak ada lagi. ${ }^{25}$

Dengan demikian bahwa psikologis itu bukanlah semata-mata penelitian terhadap pribadi seseorang saja, akan tetapi dapat pula untuk menyusun pola

\footnotetext{
${ }^{25}$ Ibid, hlm. 18.
} 
penjahat atau sebagian orang banyak dan akibatnya dalam suatu tindakan baik itu secara positif ataupun secara negative artinya kita tinggal melihat dari segi modus operandinya dari sipelaku tersebut. ${ }^{26}$

Sehubungan dengan psikologis-kriminil W.A. Bonger ada memberikan penggolongan terhadap psikologis-kriminil dalam dua alternatif yaitu dalam arti sempit dan dalam arti luas:

1. Pengertian dalam arti sempit yaitu; meliputi pelajaran jiwa sipenjahata secara perseorangan;

2. Pengertian dalam arti luas, meliputi arti sempit, maksudnya dari perbuatan sipenjahat tersebut tidak saja perseorangan akan tetapi ikut sertanya kolompok-kolompok yang telah terorganisir, baik itu secara langsung maupun tidak lansung serta akibat-akibatnya yang akan menimbulkan suatu peristiwa pidana, serta turut campurnya korban dalam hal peristiwa yang terjadi, baik itu telah terdahulu terencana oleh pelaku atau akibat dari informasi yang diberikan oleh korban agar peristiwa pidana dilakukan karena peluang telah tercipta dari korban itu sendiri.

Terkait dengan analisis secara psikologis tersebut diatas, para korban juga dikaitkan pada berbagai kerugian dengan suatu rangkaian akibat atau efek atas tindak pidana. Hal tersebut secara umum digambarkan sebagai konsekuensi sosial dan psikologis.

Dampak sosial dan psikologis yang paling terasa terjadi pada korban tindak pidana seksual khususnya perkosaan. Korban perkosaan sering menjadi sorotan dan pengunjingan serta penguncilan oleh masyarakat sekeliling. Banyak di antara korban karena merasa malu kemudian memutuskan untuk berdiam di rumah, berhenti sekolah atau berhenti kerja sebagai akibat reaksi sosial di sekitarnya. Pada akhirnya ia akan tersaing dari dunia sekelilingnya. Ini merupakan wujud kerugian sosial yang diderita. Oleh karena itu banyak di antara korban semacam itu kemudian meninggalkan lingkungan sosialnya, pindah ke lain tempat yang dianggap aman dari perhatian masyarakat.

\footnotetext{
${ }^{26}$ Ibid. hlm. 19.
} 
Kerugian dari aspek psikologis cenderung lebih berat. Menurut Jersild (1973), trauma yang pernah dialami seseorang akibat tindakan menyakitkan dan menakutkan akan terus membekas pada diri seseorang. Orang yang terus menerus dalam keadaan tegang, bimbang,takut, lambat laun akan mengalami kelaianan jiwa (psychoneurose) yang manifestasinya dapar bermacam-macam, mulai dari yang ringan sampai yang berat (Lefrancois, 1984).

Korban pemerkosaan sangat potensial mengalami kelainan kejiawaan semacam itu. Mereka tidak mau bergaul, enggan makan, engan membersihkan diri, sehingga fisiknya menjadi lemah dan sakit, maka timbulah psychosomatic (Djam'an 1970).

Apabila yang menjad korban perkosaan adalah wanita yang masih gadis, maka akibat yang ditimbulkan berupa kerugian dan penderitaan cenderung lebih besar dan berat. Seorang gadis berumur 19 tahun yang diperkosa pada usia 17 tahun suatu saat mengatakan bahwa "pemerkosaan mengambil sesuatu dari diri saya yang tidak akan pernah lagi saya miliki”. Akibatnya korban pemerkosaan mengalami kerugian control, otonomi, kekuatan, dan kebanggan diri. Banyak aspek dehumanisasi perkosaan yang mengarah pada kerugian diri dan korban merasakan kekurangan yang besar dari kekuatan ego dan identitas (Viani, 1976).

Banyak korban yang menyalahkan dirinya sendiri atas terjadinya perkosaan tersebut. Korban juga menyebutkan perasaan menjadi kotor dan utnuk beberapa kasus yang timbul persoalan-persoalan tentang perkawinan dan muncul rasa tidak percaya terhadap laki-laki.

Peters (1973) dalam laporan studi tentang efek korban perkosaan yang merupakan data pendahuluan mengidentifikasikan bahwa korban selain mengalami derita fisik ia akan merubah kebiasan makan dan tidur,mempunyai rasa takut akan serangan balas dendam, taku diperkosa lagi, takut reaski negarif keluarga, dan menunjukan tanda derita emosional lain.

Dalam studi Weis dan Borges (1973) atas dasar wawancara dengan responden yang tidak disebutkan satu persatu, menunjukan bahwa akibat pemerkosaan adalah "menurut harga diri, konsekuensi ketidak mampuan untuk 
menyenangkan dalam hubungan heteroseksual secara normal, dan perilaku ancaman bunuh diri”.

\section{Lamanya Penderitaan}

Beberapa penelitian telah dilakukan terhadap lamanya dampak kerugian dan/atau penderitaan yang dialami korban akibat tindak pidana. Secara umum berdasarkan hasil wawancara menunjukan bahwa korban mengalami penderitaan yang dapat berkelanjutan. ${ }^{27}$

Pada wawancara perta, hanya 24 korban (9\%) yang mengatakan bahwa mereka benar-benar tidak terkena dampak kejahatan. Dalam hasil wawancara, $75 \%$ dari yang diwawancara masih menyebutkan beberapa akibat. Tentang berbagai macam akibat tindak pidana berserta lama penderitaan pada tiap kasus yang dilakukan oleh pelaku tindak pidana itu sendiri.

Dalam hal ini menunjukan prosentase lama pengaruh yang diderita korban. Pengaruh tersebut dibedakan menjadi kerugian keuangan (Financial loss), pengaruh fisik (physical effect), dan pengaruh psikologis (phychology effect). Sebagai tambahan, disertkan pula tiga kategori lainnya. "any effect" mencakup semua kategori, "Possible emotional need" mencakup semua pengaruh yang mungkin memperngaruhi keuangan korban. Sehingga pernyataan kehilangan kesempatan cuti, gigi palsu, atau kaca mata dan pakaian robek dapat dimasukkan ke kerugian uang. Ketiga kategori tambahan ini dimasudkan untuk member bantuan. Kategori "possible emotional need" dimasudkan untuk memberikan bantuan emosional dan "possible financial need" dimaksudkan untuk memberikan bantuan keuangan.

Jangka waktu pengaruh dari berbagai tindak pidana terhadap korban uga diteliti oleh Maguire (1982) untuk korban perampokan. Brown dan Yantzi (1980) meneliti untuk warga Kanada korban segala jenis tindak pidana. Temuan pengaruh yang diderita korban juga cenderung sama. Para korban berharap ada kemajuan dalam kasus yang menimpa mereka dan juga imbalan, serta dilakukan pendekatan konservatif oleh para professional dalam system hukum pidana.

\footnotetext{
${ }^{27}$ Ibid.,.hlm. 19.
} 
Pengaruh - Pengaruh tersebut dapat diringkas yaitu:

a. Korban biasanya menderita secara fisik dan emosional setelah tindak pidana. Ada yang perlu perawatan medis, kebanyakan memerlukan dukungan emosional. Peran teman atau keluarga sangat berarti di sini. Namun ada pula korban yang cenderung mengasingkan diri atau terasing dan sulit mengungkapkan perasaan kecuali kepada teman paling dekat (terutama bagi korban tindak pidana seksual). Perilaku polisi menangani kasus di tempat kejadian perkara akan sangat berpengaruh pada diri korban. Para korban berharap polisi benar-benar menangani kasus mereka secara serius.

b. Jumlah korban yang mengemukakan kerugian keuangan mereka (yang tidak memiliki kartu jaminan social) hanya sedikit. Pengaruh ini baru muncul setelah beberapa bulan. Ada pula yang mengatakan hal ini sangat memberatkan, karena di samping mereka belum sanggup kerja, kerugian material, misalnya kaca mata, juga tak sanggup mereka beli.

c. Di lain pihak, pengaruh mental, fisik dan pengaruh keluarga dan lingkungan social akan memberatkan bagi korban. Mereka merasakan hal ini sangat berat. Beberapa dari mereka mengharap dukungan dari kelompok penyantun dan pendukung korban. Pengaruh inilah yang dirasa paling berat, setelah korban menerima bantuan keuangan.

d. Dalam kaitannya dengan system hukum pidana dan sumber konpensi korban mengharapkan adanya informasi dan kemajuan pada kasus mereka. Kontak mereka dengan proses hukum dalam minggu-minggu pertama atau 24 jam pertama sangat intensif (Shapland dkk, 1981). Namun rasa membutuhkan informasi dan konsultasi tersebut juga diungkapkan kepada proses hukum lainnya pula. Hal yang dianggap paling penting adalah penyelesaian kasus mereka.

\section{Perhatian Terhadap Korban Tindak Pidana}

Korban tindak pidana sebagai pihak yang menderita secara fisik, psikis dan/atau material atas akibat suatu tindak pidana Nampak cenderung terlupakan dalam Sistem Peradilan Pidana (SPP). Beberapa pakar menyebutnya dengan 
berbagai macam istilah dan komentar untuk hal dimaksud. Shapland mengatakan bahwa korban tindak pidana menjadi "forgotten man" (Shapland, et al. 1985) dalam SPP atau "kurangnya memperhatikan peran korban dalam proses pidana" (Shapland, et al. 1985); Harding (1982) mengatakan bahwa Negara melalui pejabat dalam SPP sedikit kurang memberikan perhatian pada kebutuhankebutuhan korban. Demikian pula Karmen (1984), Graborsky (1987) menggambarkan korban tindak pidana sebagai "invisible" atau "forgotten". Bahkan Elias (1986), menggibaratkan korban menjadi korban keduakalinya (a second victimization) dalam SPP atau warga Negara klas dua (a second class citizen) (1986).

Dalam situasi demikian maka tepat bila Cristie (1977) mengatakan bahwa korban merupakan pihak yang kalah total dalam situasi ini (dalam SPP). Paling utama adalah hilangnya keterlibatan diri dalam kasus yang menimpanya.

Patut disayangkan bahwa korban terlupakan dalam SPP terutama pasca penanganan oleh Polisi. Minimal terdapat dua hal yang harus direnungkan bersama selain untuk perlindungan terhadap korban serta menuju putusan yang memenuhi rasa keadilan. Pertama, atas "jasa” korban tindak pidana yang memegang peranan penting dalam tahap sub system kepolisian dan kedua, atas kerugian dan/atau penderitaan korban yang dialami.

Dalam beberapa literatur dapat menunjukan betapa korban "berjasa" dalam proses SPP terutama pada sub sistem kepolisian. Bukan saja karena dia secara aktif mengadukan perlaku ke polisi, namun juga karena dialah pengidentifikasi untama pelaku tindak pidana (shapland, et al. 1985). Pendapat tersebut berdasar suatu hasil penelitian Shapland (1986) yang secara kuantitatif menunjukan angka antara 35\% sampai $41 \%$ kasus-kasus yang terjadi dilaporkan,oleh korban sendiri. Sebanyak $50 \%$ dilaporkan oleh orang lain, seperti tetangga, teman atau mereka yang berada di tempat dimana terjadi kejahatan dan hanya 3\%-4\% kasus yang ditemukan sendiri oleh polisi.

Demikian pula hasil penelitian Maguire tahun 1980 (shapland, 1986) menunjukan lebih dari $60 \%$ kasus terdeksi atas hasil informasi secara jelas (nama atau alamat) yang diberikan oleh korban. 
Atas terabaikannya korban dalam tindak pidana ini meskipun telah "berjasa" dan telah mengalami penderitaan dan/atau kerugian, maka merupakan representasi atas belum adanya perlindungan hukum terhadap korban tindak pidana dan di lain pihak menjadikan putusan hakim menjadi bias serta tidak memenuhi rasa keadilan bagi pihak korban, pelaku serta masyarakat pada umumnya.

\subsection{Peranan Dan Risiko Korban (Viktimisasi)}

Tujuan viktimologi yang kedua menurut Separovic adalah menjelaskan sebab-sebab terjadinya korban (viktimisasi). Kajian ini menyerupai salah satu ruang lingkup dalam kriminologi yang disebut sebagai etiologi kriminil. Namun aspek yang dilihat berbeda. Dalam kriminologi dilihat dari aspek pelaku, sedangkan dalam viktimologi yang dilihat dari aspek korbannya.

Sebenarnya setiap orang tidak tergantung pada usia, jenis kelamin, bangsa, pekerjaan, strata sosial atau penggolongan lainnya terbuka bagi kemungkinan suatu serangan tindak pidana. Dengan kata lain semua anggota masyarakat berpeluang menjadi korban. Namun berdasarkan kajian viktimologi, dapat dideskripsikan tentang kecenderungan-kecenderungan terjadinya korban yang dikaitkan dengan berbagai factor.

Dalam beberapa literature menunjukan bahwa untuk terjadinya viktimisasi ini dapat disebabkan oleh beberapa factor. Faktor dimaksud secara garis besar berdasarkan kriterium sifatnya dapat dibedakan menjadi dua yakni peranan korban dan risiko korban.

\section{Peranan Korban}

Dalam kajian viktimologi, terjadinya viktimisasi peranan korban dapat menjadi faktornya. Artinya korban dipandang dapat memainkan peran dan menjadi unsure yang penting dalam terjadinya tindak pidana yang menimbulkan korban (viktimisasi). Dalam novel Franz Werfel berjudul "The Murdered One is Guilty" (Der Ermoerdete ist shuld) yang terkenal, pada intinya isinya mengatakan bahwa korban itu sendiri merupakan orang yang banyak menyebabkan kejahatan. Begitu eratnya peranan korban dalam terjadinya viktimisasi yang disebabkan adanya interkasi terlebih dahulu antara korban dan pelaku, Hentig menghipotesakan bahwa dalam beberaoa hal, korban membentuk dan mencetak penjahat dan kejahatannya 
(Schafer, 1968). Dalam kasus pembunuhan misalnya sebagaimana yang dikemukakan oleh Wolfgang, berdasarkan analisis terhadap studi statistic ditemukan bahwa satu korbam di antara empat kasus pembunuhan ikut mempercepat pembunuhan tersebut. Begitu pula yang dikemukakan oleh Amir yang mengkaji korban kasus perkosaan, yang menunjukan bahwa korban berpartisipasi dan mempercepat satu di antara lima kasus perkosaan (Separovic, 1985) Hasil studi tersebut diperkuat oleh hasil penelitian Meir dan Meite (1993), menunjukan bahwa dalam kasus perkosaan tingkat Victim Preciptation (VP) mencapai sekitar 4-19\% karena kelalaian korban. Dengan demikian maka dalam terjadinya viktimisasi, korban dapat ikut berpedan, atas hasil interaksi sebelumnya antara pelaku dan korban. Berdasarkan tingkat kesalahan korban, Mendelsohn membuat suatu tipilogi korban yang diklasifikasikan menjadi 6 tipe (Schafer, 1968). Tipilogi yang dimaksud adalah sebagai berikut :

a. The "completely innocent vicim". Korban yang sama sekali tidak bersalah oleh Mendelsohn dianggap sebagai korban "Ideal” yang cenderung terjadi pada anak-anak dan mereka juga tidak menyadari ketika ia menjadi korban.

b. The "victim with minor guilt" and the victim due to his-ignorance". Korban dengan keasalahan kecil dan korban yang disebabkan kelalaian dapat dicontohkan seorang wanita yang menggoda tetapi salah alamat. Sebagai akibatnya justeru ia menjadi korban.

c. The "victim as guilty as the offender" and "voluntary victim". Korban sama salahnya dengan pelaku dan korban sukarela ini oleh Mendelsohn dibagi menjadi beberapa sub tipe sebagai berikut :

1) Bunuh diri “dengan melemparkan uang logam";

2) Bunuh diri dengan adhesi;

3) Euthanasia;

4) Bunuh diri yang dilakukan oleh suami isteri (misalnya pasangan suami isteri yang putus asa karena salah satu pasangannya sakit).

d. The 'victim more gulty than the offender'. Dalam hal korban kesalahannya lebih besar dari pada pelaku ini ada dua tipe yakni : 
1) Korban yang memancing dan atau menggoda seseorang untuk berbuat jahat;

2) Korban lalai yang mempengaruhi seseorang untuk melakukan kejahatan.

e. The"most guility victim" and the" victim as is guilty alone". Korban yang sangat salah dan korban yang salah sendirian misalnya terjadi pada korban yang sangat negative terlebih dahulu melakukan kejahatan namun akhirnya justru ia sendiri yang menjadi korban (misalnya penyerangan yang mati akibat pembelaan diri dari orang lain yang diserang).

f. The"simulating victim" and the "imagine as victim". Korban pura-pura dan korban imajinasi oleh Mendelsohn dicontohkan pada mereka yang mengaku menjadi korban demi kepentingan tertentu atau orang yang menderita paranoid. Histeriat serta pikun.

Hampir sejalan dengan Mendelsohn yang membuat tipologi korban berdasarkan tingkat kesalahan, Ezzat A.Fatta juga mengklasifikasikan korban yang ia dasarkan atas tingkat pertamanya. Tingkatannya dimulai dari korban yang sama sekali tidak berperan sampai korban yang berperan paling kuat, terdiri atas:

a. nonparticipating victims, who feel a denial or repulusion toward the crime and the criminal, and who do not partipate in the origin of the crime committed against them; Artinya (makna) : non berpartisipasi korban, yang merasa penolakan atau repulusion terhadap kejahatan dan kriminal, dan yang tidak partipate dalam asal-usul kejahatan yang dilakukan terhadap mereka;

b. Latent or predisposed victim, who heve certain character presdispotions for being victimized by certain kinds of offenses; Artinya (makna): Laten atau korban cenderung, yang presdispotions karakter download heve tertentu untuk menjadi korban beberapa jenis pelanggaran.

c. Provocative victim, who participate the crime, or even provoke it; Artinya (makna): Korban provokatif, yang berpartisipasi kejahatan, atau bahkan mendorongnya 
d. Participating victims, who by their passivity or other similar attude make their own victimization possibsierle or easier. Artinya (makna): Berpartisipasi korban, yang dengan pasif atau sikap yang sama lain membuat korban mereka sendiri mungkin atau mudah.

e. False victims, who ar not victim at all or who victimize them selves (Separovic,1985). Artinya (makna): Salah korban, korban yang tidak sama sekali atau yang mengorbankan dirinya (Separovic, 1985).

\section{Resiko Korban}

Resiko korban mengandung suatu pengertian bahwa dalam kondisi dan situasi tertentu cendrung mudah terjadi viktimisasi. Dalam studi terhadap terjadinya kejahatan menunjukan bahwa cirri-ciri tertentu, keteraturan, unsur-unsur tipikal kepada kepribadian korban, serta sikap korban terhadap pelaku dalam terjadinya kejahatan (Separovic,1985) Risiko korban menurut Separovic (1985) terdiri atas :

a. Pribadi, di sini termasuk factor biologis (usia, jenis kelamin, kesehatan, terutama kesehatan jiwa);

b. Sosial, disini yang dimaksud adalah korban buatan masyarakat, imigran, minoritas, jabatan, hubungan pribadi dll; dan

c. Faktor situasi, yaitu keadaan konflik, tempat dan waktu.

Dapat pula dimasukkan dalam risiko korban adalah tipiologi korban menurut Hans von Hentig yang memakai suatu klasifikasi sosiobiologi dengan mendasarkan factor psikologis, social dan biologis (Separovic, 1985)

Hentig membagi tipe korban menjadi 13 macam sebagai berikut.

a. The young. Anak-anak mempunyai risiko menjadi korban berbagai macam tindak pidana, disebabkan karena lemah secara fisik dan mental kepribadiannya belum matang serta belum mempunyai ketahanan yang cukup apabila harus menghadapi serangan terutama dari orang dewasa. Anak-anak tidak hanya dapat menjadi korban atas tindak pidana terhadap harta kekayaan. Namun juga dapat menjadi korban tindak pidana seksual baik yang laki-laki maupun perempuan. Leppman sebagaimana yang 
dikutip pendapatnya oleh Hentig menunjukan bahwa beberapa anak perempuan tidak tahan terhadap serangan seks, yang disebabkan karena beberapa hal meliputi rasa ingin tahu, takut, kelemahan jasmani serta tingkat intelektualnya yang belum matang. Anak-anak terkadang juga menjadi korban dari orang-orang dewasa yang memperalatnya untuk melakukan tindak pidana terutama jenis tindak pidana terhadap kekayaan. Di beberapa Negara telah dibuat peraturan perundang-undangan yang bertujuan untuk melindungi anak-anak semacam itu yang pada hakikatnya telah menjadi korban. Rancangan Kitab Undang-Undang Hukum Pidana Indonesia merumuskan bahwa dalam hal ada tindak pidana yang dilakukan dengan mengikut sertakan anak-anak, maka bagi pelakunya yang dewasa mendapat ancaman pidana yang diperberat. Ancaman pemberatan semacam ini dalam KUHP belum diatur. Namun yang di luar KHUP sudah ada sebagian yaitu dalam Undang-undang Nomor. 9 tahun 1976 tentang Narkotika.

b. The female. Oleh Hentig dikatakan bahwa wanita merupakan korban dengan bentuk kelemahan lain. Wanita muda kadang-kadang menjadi korban pembunuhan sesudah mengalami serangan seks; wanita tua yang dianggap kaya sering menjadi korban ataas tindak pidana terhadap harta kekayaan. Yang dimaksud oleh Hentig bahwa wanita mempunyai bentuk kelemahan lain adalah di samping lemah jasmaninya (apabila dibandingkan dengan pria dan pelakunya biasanya juga pria) wanita juga diasumsikan mempunyai dan/atau memakai barang-barang seperti perhiasan yang mempunyai nilai ekonomis tinggi.

c. The old. Orang tua, mempunyai resiko menjadi korban atas tindak pidana terhadap kekayaan. Oleh Hentig dikatakan bahwa generasi tua memegang sebagian besar posisi kekayaan yang sudah teakumulasi. Disisi lain terdapat kelemahan, pada jasmaninya atau terkadang mentalnya yang mulai lemah. Dalam kombinasi antara akumulasi kekayaan dan kelemahan inilah terletak bahaya untuk risiko menjadi korban. Hentig bahkan 
membuat pernyataan bahwa orang tua adalah korban yang ideal dari serangan predator.

d. The mentally the fective and order mentally deranged. Orang yang cacat jiwa, orang gila, peminum, pecandu obat bius, psikopat oleh Hentig disebut sebagai korban yang petinsial dan aktual. Ini disebabkan karena dengan kondisi seperti itu mereka tidak mempunyai kemampuan apabila harus menghadapi suatu serangan ataupun tindak pidana. Hentig menyatakan bahwa dari semua pria korban pembunuhan, 66,6\% adalah pecandu minuman alcohol. Ditemukan pula bahwa $70 \%$ dari korban pembunuhan ternya dalam kondisi mabuk. Orang mabuk mempunyai risiko untuk menjadi korban berbagai macam tindak pidana khususnya tindak pidana terhadap harta kekayaan, seperti pencurian, pencopetan, penipuan, dan lain-lain.

e. Immigtans. Golongan imigran mempunyai risiko untuk menjadi korban berbagai macam tindak pidana seperti pemasaran, penipuan. Faktor penyebabnya antara lain karena kesulitan yang mereka hadapi dalam beradaptasi dengan bahasa dan budaya baru di daerah tempat tinggalnya yang baru. Dengan kelemahan yang ada itu sering dimanfaatkan secara negatif oleh kelompok-kelompok tertentu untuk mengambil keuntungan. Apalagi terhadap imigran-imigran gelap yang tidak dilengkapi dengan dokumen yang sah. Dapat dicontohkan seperti yang terjadi pada kaum imigran Indonesia di Malaysia. Mereka sering menjadi obyek bisnis yang potensial oleh para Tekong untuk megambil keuntungan besar dengan memanfaatkan kelemahan-kelemahan para imigran, apalagi imigran gelap.

f. Minorities. Posisi minoritas sebagai pihak yang mempunyai risiko untuk menjadi korban menyerupai dengan risiko sebagaimana para imigran. Penyebabnya yang lebih menonjol, tidak adanya persamaan hukum dibandingkan dengan para mayoritas. Prasangka rasial dari kelompok mayoritas terhadap kelompok minoritas cenderung lebih menambah dalam hal risiko menjadi korban. 
g. Dull normals. Bagi orang yang normal tetapi bodok menurut Hentig merupakan korban sejak lahir. Artinya orang bodoh mempunyai risiko menjadi korban sejak ia dilahirkan dikarenakan oleh tingkat intelejensianya yang kurang. Keberhasilan penipu terhadap orang bodoh tidak dapat dikatakan karena kecerdikan penipu, tetapi lebih disebabkan karena kebodohan korbannya.

h. The depresser. Orang yang ditekan perasaanya akan menjadi lemah. Dengan tertekannta seseorang akan menyebabkan merosotnya kekuatan fisik maupun mental. Dalam kondisi ini mempunyai risiko menjadi korban karena mereka cenderung apatis dan menyerah serta tidak mempunyai sifat untuk berjuang melawan pelaku.

i. The acquisitive. Orang serakah disebut pula sebagai "korban unggul lainnya". Orang serakah mempunyai risiko untuk menjadi korban penipuan, sindikat penjahay, perjudian dan sebagainya. Para pelakunya dimotivasi atau memanfaatkan sifat keserakahan dan ketemakan dalam mencari pendapatan yang berlimpah dengan cara yang mudah. Beberapa contoh dialami oleh korban-korban penipuan arloji dengan merek terkenal yang ternyata palsu, pelipat gandaan uang oleh orang-orang yang mengaku pintar, dan lain-lain.

j. The wanton. Orang ceroboh mempunyai risiko menjadi korban karrena kelalaiannya dalam berbagai hal. Dapat dicontohkan pada orang yang lupa mengunci mobil, rumah, dan lain-lain.

k. The lonesome and heatbroken. Orang kesepian dan patah hati mempunyai risiko yang potensial menjadi korban. Hentig mencontohkan dengan pembunuhan masal yang terkenal. Hendri Desire Landru, Fritz Kaarman, juga Jack Ripper. Mereka mengambil keuntungan dari para korbannya yang merasa kesepian dan patah hati. Orang kesepian dan patah hati juga berisiko untuk menjadi korban pembunuhan, pencurian, penipuan dan lain-lain.

1. Tormentors. Orang yang suka menyiksa mempunyai risiko untuk menjadi korban, sering dialami dalam tragedy keluarga. Seorang suami yang suka 
menyakiti baik secara fisik maupun psikis terhadap isterinya sering menjadi korban pembunuhan yang dilakukan oleh anaknya.

m. The blocked, exempted, and fighting. "orang yang terhalang, bebas dan suka berkelahi "mempunyai risiko yang berbeda untuk terjadinya viktimisasi. Orang yang terhalang diartikan sebagai individu yang berada dalam posisi dan kondisi sulit untuk keluar dari bahaya. Dapat dicontohkan misalnya pada seorang yang mendapat ancaman melalui surat kaleng tetapi suli untuk mendapat bantuan dari pihak kepolisian. Untuk tipe "bebas dan suka berkelahi" termasuk dalam risiko korban kecil karena mereka mempunyai keleluasaan dan kekuatan yang cukup untuk menahan serangan.

Selain tipilogi yang menunjukan adanya risiko untuk terjadinya viktimisasi sebagaimana disebutkan oleh Hentig tersebut di atas, Schafer (1968) juga memberikan beberapa risiko korban yang dikaikan dengan situasi daerah dan masyarakatnya.

Pada masyarakat kecil fruekuensi tindak pidana pembunuhan dan tindak pidana dengan pemberatan relative tinggi, sedangkan frekuensi tindak pidana terhadap harta kekayaan cenderung rendah. Hal ini menurut Schafer karena pada masyarakat kecil kontak atau interaksi di antara warga cenderung meningkat dan dalam hal ini cenderung pula terjadi konflik atau benturan kepentingan di antara mereka. Pada masyarakat kecil relative kecil pula untuk terjadinya tindak pidana terhadap harta kekayaan karena kesempatannya juga lebih kecil dibandingkan pada masyarakat besar yang berpenduduk 10.000-100.000. pada masyarakat besar frukuensi perampokan dan pencurian menunjukan peningkatan tajam. Dengan deskripsi tersebut maka dapat dikatakan bahwa pada masyarakat kecil mempunyai risiko kecil untuk menjadi korban tindak pidana harta kekayaan, tetapi untuk menjadi korban tindak pidana terhadap nyawa cenderung tinggi.

Pada daerah-daerah bisnis di pinggiran kota, dan pada daerah-daerah bisnis kota kecil yang terdapat kecil harta benda berharga, tindak pidana pencurian dengan kekerasan sangat mendominasi. Artinya pada daerah tersebut risiko yang besar adalah menjadi korban tindak pidana pencurian dengan kekerasan. 
Pada daerah permukiman, risiko yang ada adalah menjadi korban pembunuhan dan penganiayaan, karena pada daerah tersebut interaksi antar warga cenderung tinggi dan intim dibandingkan dengan daerah bisnis. Faktor ini relative sama dengan yang terjadi pada daerah kecil.

Terdapat kecenderungan berisiko untuk menjadi korban tindak pidana kekerasan di jalan-jalan utama. Ini disebaban pertimbangan dari pelakunya yang mempunyai kesempatan lebih mudah untuk melarikan diri dibandingkan dengan di jalan-jalan kecil. Individu yang saling konflik berada di rumah atau apartemen berisiko menjadi korban tindak pidana pembunuhan, karena tindak adanya orang yang dapat melerai serta mencegah apabila terjadi pertengkaran. Dususu lain bagi pelakunya kondisi tersebut dipertimbangkan untuk meniminalkan saksi. Steinmetz membedakan tiga factor utama yang mempunyai risiko viktimisasi meliputi attractiveness, proximity dan exposure (Wikstrom, 1991).

a. Attractiveness secara luas mengacu pada nilai bagi pelaku tindak pidana potensial melakukan tindak pidana terhadap obyek tertentu.

b. Faktor proximity dibagi menjadi dua yaitu pendekatan social dan geografik. Factor yang pertama berkaitan dengan tingkat hubungan yang dimiliki seseorang dengan pelaku tindak pidana potensial sebagai akibat dari gaya hidupnya. Yang kedua terutama berkaitan dengan perbandingan tempat tinggal dan issu mengenai tindak pidana dan jarak yang sama. Risiko viktimisasi tersebut diasumsikan lebih besar bagi yang hidup di dalam atau berdekatan dengan wilayah dengan banyak pelaku tindak pidana potensial. Risiko paling besar bagi viktimisasi personal, menurut factor proximity adalah bago orang yang hidup di lokasi tertentu dan pindah di sekotar lokasi perkotaan dengan cara demikian orang tersebut menjadi sering berhubungan dengan pelaku tindak pidana potensial.

c. Factor exposure diartikan sebagai sejauh mana pelaku tindak pidana diberikan kesempatan untuk melakukan tindak pidana ketika mereka behubungan dengan target yang sangat menarik. 


\subsubsection{Restitusi dan Kompensasi}

Restitusi dan kompensasi merupakan bagian atas kebijakan dalam upaya mengurangi penderitaan bagi korban. Dalam viktimologi sebagaimana yang telah disebutkan dalam bab terdahulu, tujuan membuat kebijakan guna mengurangi penderitaan bagi korban , oleh Mendelsohn (1985) dikatakan sebagai tujuan yang terpenting, karena dengan demikian dapat lebih memberdayakan masyarakat serta menjamin kehidupannya. ${ }^{28}$

\section{Istilah Restitusi dan Kompensasi}

Isitilah restitusi dan kompensasi merupakan istilah yang sering dipakai secara bergantian, yang sebenarnya menggambarkan dua titik pandang yang berbeda.

Kompensasi dalam viktimologi adalah berkaitan dengan keseimbangan korban akibat dari perbuatan jahat. Perbuatan jahat tersebut merugikan korban, oleh karena itu dapat disebut kompensasi atas kerugian baik fisik, morel maupun harta benda yang diderita korban atas suatu tindak pidana. Kompensasi juga merupakan suatu indikasi pertanggungjawaban masyarakat atas tuntutan pembayaran kompensasi yang berkarakter perdata. Dengan demikian tergambar suatu tujuan non pidana dalam kasus pidana (Iswanto, 1995).

Kebalikan kompensasi ialah restitusi. Restitusi dalam viktimologi adalah berkaitan dengan perbaikan atau restorasi perbaikan atas kerugian baik fisik, morel mauoun harta benda, kedudukan dan hak-hak korban atas serangan penjahat. Restitusi juga merupakan indikasi pertanggungjawaban pembuat tindak pidana atau penjahat; jadi restitusi merupakan suatu tindakan restitutif terhadap penjahat atau pembuat yang berkarakter pidana yang menggambarkan suatu tujuan koreksional dalam kasus pidana. Jelasnya bahwa kompensasi korban diminta oleh korban atas dasar bentuk permohonan dan apabila dikabulkan dibayar oleh masyarakat (Negara), sedangkan restirusi dituntut oleh korban agar diputus oleh pengadilan dengan proses peradilan pidana dan apabila diterima tuntutannya dibayar oleh penjahat atau pembuatnya (Iswanto, 1995).

\footnotetext{
${ }^{28}$ Ibid., .hlm. 37.
} 


\section{Sejarah Singkat Restitusi}

Dalam buku Schafer (1968) yang berjudul "The Victim and His Criminal a Study in Functional Responsibility" pembahasan korban dibagi dalam tiga perio yaitu "The Golden Age of the Victim" (jaman keemasan korban), "The Decline of the Victim" (jaman kemunduran korban) dan 'The Revival of the victim's Importance " (jaman kebangkitan korban).

Pada jaman keemasan korban, keharusan ganti kerugian atas kehilangan atau kerugian akibat tindak pidana ditanggung oleh pembuat korban (Schafer, 1968).

Jaman keemasan korban, diawali ketika masyarakat masih dalam kebudayaan primitif. .Dalam kebudayaan primitive korban tindak pidana menghukum penjahat melalui pembalasan atau balas dendam. Korban yang menderita luka jasmani atau kerusakan, keluarga korban atau korban berhak mengambil apa yang ia inginkan dari penjahat itu sebagai ganti rugi atas tindak pidana. Dalam hal demikian, “control social” berada di tangan seorang laki-laki. Ia sebagai pembentuk hukum, korban, penuntut umum, hakim dan sekaligus sebagai eksekutor.

Dalam kasus yang menyangkut perbuatan jahat dilakukan terhadap suatu keluarga, marga atau salah sat anggotanya oleh seseorang di luar kelompok, maka kelompok korban turut dalam pembalasan, atau "balas dendam berdarah" atau “permusuhan berdarah'. Pada saat itu terjadi perubahan arah control social yaitu dari control social individu ke control keluarga, atau klan korban.

Fakta yang demikian merupakan konsep asli "pertanggungjawaban kolektif”. Kondisi semacam itu terjadi tidak terlepas dari lembaga politik yang masih berdasarkan ikatan keluarga atau ikatan suku bangsa dan belum ada kekuasaan sentral yang berwenang menentukan kesalahan dan bentuk pidana.

Ketika kelompok primitif menetap, mencapai tingkat perkembangan ekonomi tinggi, dan mulai memiliki persediaan barang ekonomi lebih banyak, serta bergesernya nilai-nilai yang ada, ganti kerugian atas luka jasmani atau mental dan balas dendam, dapat digantikan dengan barang-barang yang mempunyai nilai ekonomis atau uang.

Besarnya ganti rugi tergantung beberapa factor yang menjadi acuan. Di contohkan pola Ifugqo di Luzon Utara, penentuan ganti kerugian korban 
dipertimbangkan dari lima factor yang bersifat kritis yaitu: sifat kejahatan; kedudukan klas yang terlibat dalam perkara; solidaritas dan tingkah laku dari dua kelompok yang bertentangan, kepribadian dan reputasi dari dua kelompok; serta kedudukan geografis dari dua kelompok yang berpekara.

Di beberapa tempat berbeda misalnya Jerman, tingkat kerugian diukur juga dengan sifat kejahatan;umur; kedudukan kelamin; serta martabat korban. Hal ini dilakukan melalui system perundingan antara pihak korban dan pelaku. Proses perundingan dan pembayaran kepada korban menjadi dikenal sebagai proses "komposisi".

Di inggris, di bawah system ini, penjahat dapat membeli kembali perdamaian yang telah ia rusak dengan membayar "pesangon" kepada korban atau familinya menurut sebuah daftar tarif luka-luka. Undang-undang "Dooms of Alfred" yang berlaku dalam jaman Raja Alfred, contohnya, menetapkan bahwa kalau seseorang menampar sampai lepas gigi seri orang lainnya, ia harus membayar delapan shilling; kalau itu gigi taring, empat shilling; dan kalau geraham lima belas shilling. Pada masa Alfred, sekitar tahun 870, balas dendam pribadi oleh korban disetujui oleh masyarakat sesudah permintaan ganti rugi oleh korban dan permintaanya ditolak oleh pembuat itu, pembuat yang tidak member ganti rugi kepada korban dinyatakan sebagai orang di luar perlindungan hukum (friedlos), dan sebagai akibatnya siapa saja boleh membunuh tanpa dijatuhi hukuman apapun.

Peralihan atau perubahan dari balas dendam keg anti rugi ternyata terjadi pada banyak kebudayaan primitive ketika mereka telah mapan dan ekonominya menjadi stabil. Sebagai contoh yang menyolok terjadi dalam daerah-daerah primitive di Arab kira-kira seratus tahun yang lalu. Diketahui bahwa balas dendam berdarah dipraktikkan di antara suku bangsa Nomanis di luar kota-kota, sedang yang tinggal dalam kota memakai proses komposisi sebagai cara untuk menebus kesalahan penjahat guna menghadiri penghancuran social atas pembalasan dendam.

Komposisi digunakan sebagai alat untuk menghukum pelaku tindak pidana untuk membayar ganti rugi kepada korban. Hal ini terjadi pada Bangsa Babylonia Purba (di bawah Kode Hamurabi), orang Yahudi (di bawah hukum Musa), Yunani Kuno, Rum, dan Jerman KUno. Dengan demikian jelas bahwa asal usul system 
hukum pidana modern ditemukan dalam hak korban terhadap ganti rugi untuk kesalahan yang diperbuat oleh penjahat.

"Jaman keemasan korban" mulai pudar menuju "jaman kemunduran korban", tampak di Inggris, ketika raja dan kaum bangsawan mengharuskan agar penjahat membayar ganti rufi kepada korban yang disebut "Bot", dan membayar uang komisi untuk raja/masyarakat yang dusebut "wite" atas bantuan dalam menimbulkan perdamaian antara pelanggar dan korban, serta perlindungan terhadap pembalasan korban.

Pada abad ke dua belas bagian korban mulai banyak berkurang. "Wite" ditambah sampai akhirnya raja atau bangsawan mengambil seluruh pembayaran dari penjahat. Hak korban terhadap ganti rugi, dalam hal ini, diganti dengan denda, yang besarnya ditaksir oleh pengadilan dan dibayar oleh penjahat kepada raja. Hilangnya konsepsi ganti rugi kepada korban, karena keinginan pihak raja dan kaum bangsawan feudal untuk memperoleh kekuasaan yang lebih besar terhdap rakyat dan arogansi raja dan kaum bangsawan yang berusaha mengambil alih seluruh komposisi korban.

"Jaman kemunduran korban " lebih tampak ketika:

a. Negara yang terdiri atas raja dan kaum bangsawannya dengan arogansinya mengambil alih dan memonopoli lembaga hukum, sehingga hak-hak korban secara bertahap berkurang dan akhirnya seluruh hak korban beralih kepada raja dan kaum bangsawan;

b. Denda secara berangsur-angsur masuk ke kas Negara dengan pembayaran berlipat yang ditarik dari penjahat/pelanggar dan mereka tetap dipidana;

c. Kewajiban untuk mengannti kerugian menjadi terpisah dari lapangan hukum pidana;

d. Hubungan korban dan penjahat lebih memiliki aspek keperdataan dari pada aspek pidana.

Perjalanan jaman keemasan korban sehingga korban hingga jaman kemunduran korban, konsep restitusi oleh Jacob telah dikaji dan ia membagi restitusi atas beberapa tahap sebagai yaitu:

a. Balas dendam pribadi; 
b. Balas dendam kolektif;

c. Proses negoisasi dan komposisi;

d. Pengadopsian hal-hal yang berhubungan dengan jumlah komposisi yang harus diterima korban pada proses komposisi;

e. Tingkat intervensi para penguasa sebagai mediator dan umlah bayaran yan mereka peroleh dengan menghitung berdasarkan prosentase nilai kompensasi/komposisi;

f. Pengambilalihan proses peradilan dan penghapusan restitusi dari hukum pidana (Harding, 1982).

Jaman kemunduran korban pada akhirnya mendapat reaksi dari beberapa kalangan yang menuntut adanya pembelaan kembali terhadap kedudukan korban, walaupun pada awalnya masih terbatas pada pemikiran ganti rugi bagi korban tampa memandang arti konstribusi korban dalam terjadinya tindak pidana.

Salah satu pembelah korban adalah Bonneville de Marsangy pada tahun 1847 merencanakan perbaikan korban, kemudian beberapa lembaga penjara Internasional mengadakan konggres dengan penuh semangat agar dihidupkan kembali hak-hak korban tindak pidana. Raffaele Garofalo dari Itali, mengajukan masalah pada internasional Prison congress yang diselenggarakan di Roma pada tahun 1855, tentang "perbaikan kejahatan sungguh merupakan masalah keadilan dan ketentraman masyarakat”. Masalah tersebut masih juga didiskusikan lagi dalam "the international prison congress" yang diselenggarakan di St. Petersburg pada tahun 1890 dan pada "the international Penal Association Conggres" yang diadakan pada tahun 1891. Pada konggres tersebut disetujui beberapa kosimpulan sebagai berikut.

a. Hukum moderen belum cukup mempertimbangkan kerugian waktu perbaikan korban.

b. Dalam kasus tindak pidana ringan, kerugian waktu seharusnya diberikan ganti rugi.

c. Pendapat narapidana dalam penjara dapat digunakan untuk membayar ganti rugi pada korban. (Schafer,1968). 
Pada Sixth International Penitentiary Conggres yang diselenggarakan di Brussel pada tahun 1900 juga masih tetap juga didiskusikan tentant restitusi korban kejahatan tetapi juga belum berhasil sesuai atas perjuangan para pembela korban (Karmen,1968).

Para pembela korban terus berjuan tidak kenal putus asah dan diteruskan oleh para filsuf dan pakar hukum pidana antara lain Enriko Ferry dari italia pada tahun 1920-1929 memunculkan kembali tentang pengakuan restitusi korban tindak pidana. Margery Fry dari inggris pada tahun 1950=1959 mengusulkan agar pidan restitusi diakui dan dicantumkan sebagai salah satu jenis pidana (karmen, 1984).

Pada akhirnya hasil perjuangan mereka tercapai, antara lain oleh The President's Commission on Law Enforcement and the Administration of Justice (Presiden Komisi Penegakan Hukum dan Administrasi Kehakiman) yang pada tahun 1967 memberikan rekomendasi bahwa restitusi merupakan kewajiban terpidana di Negara-negara Amerika Serikat (Karmen, 1984).

Perkembangan selanjutnya atas rekomendasi tersebut, pada tahun 1970-1979 diterima dan dilaksanakan oleh United States Supreme Court (Mahkamah Agung Amerika Serikat) serta dilaksanakan juga oleh model penghukuman American Law Istitute (Amerika Hukum Istitute), model The American Bar Association dan model The National Advisory Commission Justice Standard and Goal (Karmen, 1984). Artinya (makna): Penasehat Nasional Komisi Keadilan dan Standard Goal (Karmen, 1984)

Stelah reaksi dari para pembela korban terhadap perhatian dan kedudukan korban yang mengalami kemunduran, maka sampailah pada apa yang dinamai “jaman kebangkitan kembali korban”. Dalam masa ini terdapat suatu pandangan peradilan yang menuntut agar korban dilihat lagi dalam pengertian yang lebih, baik sebagai orang yang dilukai maupun sebagai pelaku. Dengan pemikiran demikian mempunyai konsekuensi adanya pertanggungjawaban fungsional pelaku dan korbannya. Pertanggungjawaban fungsional pelaku diwujudkan dalam restitusi atau kompensasi atas kesalahan yang dilakukan terhadap korban. Pertanggungjawaban korban diujudkan dalam tuntutan terhadap korban supaya tidak melakukan 
provokasi serta merangsang penjahat untuk melakukan tindak pidana. Di samping itu korban dituntut secara aktif mencegah suatu usaha yang dapat menimbulkan viktimisasi. Dalam konteks demikian hukum pidana sudah mengalami pergeseran dari orientasinya yang individualistic kea rah universalistic.

\section{Kompensasi}

Sebagaimana telah disinggung di muka konpensasi dalam viktimologi merupakan pemberian ganti rugi terhadap korban atas kerugian fisik, morel maupaun harta benda yang diderita korban akibat suatu tindak pidana atas biaya masyarakat (Negara). ${ }^{29}$

Negara yang pertama menyetujui undang-undang tentang kompensasi atas korban tindak pidana tertentu adalah New Zealand. Undang-undang tersebut bernama Criminal Ijuries Compensation Act 1963. Undang-undang tersebut berdasarkan falsafah "kewajiban masyarakat terhdap orang-orang menderita merupakan tanggung jawab Negara, karena Negara telah gagal mencegah terjadinya tindak pidana”. Falsafah tersebut sesuai dengan makna kompensasi yang mengandung suatu indikasi pertanggungjawaban masyarakat terhdap korban atas terjadinya viktimisasi.

Di New Zealand pengadilan dapat memutus permohonan kompensasi terhdap kasus-kasus yang berakibat korban mati atau luka atas tindak pidana :

a. Perkosaan atau percobaan perkosaan;

b. Hubunganseksual atau perbuatan tidak sesonoh dengan gadis di bawah umur 12 tahun;

c. Serangan yang tidak senonoh terhadap gais antara umur 12-16 tahun atau terhadap orang perempuan atau terhadap anak laki-laki atau seorang lakilaki;

d. Pembunuhan atau pembantaian secara keji atau percobaan pembunuhan atau percobaan pembantaian secara keji;

e. Melukai dengan sejaga;

f. Melukai dengan sejaga atau perbuatan yang melawan hukum;

${ }^{29}$ Ibid .hlm. 44-45. 
g. Serangan dengan menjengkelkan, melukai;

h. Serangan dengan maksud melukai;

i. Serangan kepada seorang anak laki-laki atau perempuan;

j. Serangan biasa;

k. Cacat;

1. Penembakan dengan senjata api atau melakukan suatu perbuatan yang berbahaya dengan sengaja;

m. Membuang zat asam;

n. Peracun dengan sengaja;

o. Penularan penyakit;

p. Pembahayalakan transportasi;

q. Penculikan seorang perempuan atau seorang gadis;dan

r. Penculikan anak.

Kompensasi tidak dapat diberikan terhadap korban yang menderita kerugian materi beruapa kehilangan atau kerusakan hak milik. Dalam pemberian kompensasi terhadap korban, pengadilan (komisi) mempertimbangkan factor yang melekat pada pelaku berkaitan dengan kemampuan bertanggungjawab yang meliputi umur, kesehatan mental, pengaruh alcohol. Peranan korban misalnya korban yang mempercepat terjadinya tindak pidana (victim-precipitated crimes) diperimbangkan secara yuridis untuk perolehan bersar kecilnya nilai kompensasi. Jumlah kompensasi yang diberikan kepada korban atas dasar keputusan pengadilan (komisi) dapat dibayar secara tunai maupun secara mengangsur.

\section{Viktimologi dalam Kaitan Penanggulangan Kejahatan}

\section{a. Pengertian Viktimologi}

Apabila hendak menemukan upaya penanggulangan kejahatan yang tepat, cara pandang kita sebaiknya tidak hanya terfokus pada berbagai hal berkaitan dengan penyebab timbulnya atau metode apa yang efektif dipergunakan dalam penganggulangan kejahatan. Namun, hal ini yang tidak kalah pentingnya untuk dipahami adalah masalah korban kejahatan itu sendiri yang dalam keadaan-keadaan tertentu dapat menjadi pemicu munculnya kejahatan. 
Berbicara tentang korban kejahatan, kita tidak terlepaskan dari viktimologi. Untuk itu melalui viktimologi dapat diketahui berbagai aspek yang berkaitan dengan korban, seperti: faktor penyebab munculnya kejahatan, bagaimana seseorang dapat menjadi korban, upaya mengurangi terjadinya korban kejahatan, hak dan kewajiban korban kejahatan. Korban dalam lingkup viktimologi memiliki arti yang luas karena tidak terlepas dari individu yang secara nyata menderita kerugian, tetapi juga kelompok, korporasi, swasta maupun pemerintah, sedangkan yang dimaksud dengan akibat penimbulan korban adalah sikap atau tindakan terhadap korban dan/atau pihak pelaku serta mereka secara langsung atau tjadinya suatuidak terlibat dalam terjadinya suatu kejahatan.

Pentingnya korban memperoleh perhatian utama dalam membahas kejahatan disebabkan korban sering kali memiliki peranan yang sangat penting bagi terjadinya suatu kejahatan, diperolehnya pemahaman yang luas dan mendalam tentang korban kejahatan, diharapkan dapat memudahkan dalam menemukan upaya penaggulangan kejahatan yang pada akhirnya akan bermuara pada menurunnya kuatintas dan kualitas kejahatan.

Sejalan dengan semakin berkembangnya viktimologi, sebagai cabang ilmu hukum baru, berkembang pula berbagai rumusan tentang viktimologi. Kondisi ini hendaknya tidak dipandang sebagai pertanda tidak adanya pemahaman yang seragam mengenai ruang lingkup viktimologi, tetapi harus dipandang sebagai bukti bahwa viktimologi akan selalu berkembang sejalan dengan perkembangan yang terjadi dalam masyarakat.

Viktimologi merupakan sesuatu pengetahuan ilmiah/studi yang mempelajari suatu viktimologi (criminal) sebagai suatu permasalahan manusia yang merupakan suatu kenyataan sosial.

Perumusan ini membawa akibat perlunya suatu pemahaman, yaitu :

1. Sebagai suatu permasalahan manusia menurut proporsi yang sebenarnya secara dimensional;

2. Sebagai suatu hasil interasksi akibat adanya suatu interrelasi antara fenomena yang ada dan saling mempengaruhi; 
3. Sebagai tindakan seseorang (individu) yang dipengaruhi oleh unsure struktur social tertentu suatu masyarakat tertentu.

Pada dasarnya, perkembangan ilmu pengetahuan tentang korban kejahatan (viktimologi), tidak dapat dipisahkan dari lahirnya pemikiran-pemikiran brilian dari Hans von Hentig, seorang ahli kriminologi pada tahun 1941 serta Mendelshon, pada tahun 1947. Pemikiran kedua ahli ini sangat mempengaruhi setiap fase perkembangan viktimologi.

Perkembangan viktimologi hingga pada keadaan seperti sekarang tetntunya tidak terjadi dengan sendirinya, namun telah mengalami berbagai perkembangan yang dapat dibagi dalam tiga fase.

Pada tahap pertama, viktimologi hanya mempelajari korban kejahatan saja, pada fase ini dikatakan sebagai "penal or special viktimology". Sementara itu, pada fase kedua, viktimologi tidak hanya mengkaji masalah korban kejahatan, tetapi juga meliputi korban kecelakaan. Pada fase ini disebut sebagai "general viktimology". Fase ketiga, viktimologi sudah berkembang lebih luas lagi, yaitu mengkaji permasalahan korban karena penyalahgunaan kekuasaan dan hak-hak asasi manusia. Fase ini dikatakan sebagai "new viktimology”.

Dari pengertian di atas, tampak jelas bahwa yang menjadi objek pengkajian dari viktimologi, di antaranya pihak-pihak mana saja yang terlibat/mempengaruhi terjadinya suatu viktimisasi (criminal), bagaimanakah respons terhadap suatu viktimisasi kriminal, faktor penyebab terjadinya viktimisasi criminal, bagaimanakah upaya pengetahuannya, dan sebagainya.

\section{b. Viktimologi dalam Perkembangan}

Sejak awal mula lahirnya hukum pidana, fokus subjek yang paling banyak disoroti adalah si pelaku. Padahal dari suatu kejahatan, kerugian yang paling besar diderita adalah si korban kejahatan tersebut. Akan tetapi, sedikit sekali hukum ataupun peraturan perundang-undangan yang dapat kita temui yang mengatur mengenai korban serta perlindungan terhadapnya.

Hukum pidana memperlakukan korban seperti hendak mengatakan bahwa satu-satunya cara untuk melindungi korban adalah dengan memastikan bahwa si 
pelaku smendapatkan balasan yang setimpal. Hal yang juga disebutkan oleh Reif : " The problem of crime, always get reduced to what can be done about criminal. Nobody ask what can be done aboit victim ? everyone assumes the best way to help the victim is to catch criminal as though the offender is the only source of victims trouble. Artinya (makna): Masalah kejahatan, selalu bisa direduksi menjadi apa yang dapat dilakukan tentang kriminal. Tidak ada yang bertanya apa yang bisa dilakukan korban aboit? semua orang menganggap cara terbaik untuk membantu korban adalah untuk menangkap kriminal seolah-olah pelaku adalah satu-satunya sumber masalah korban.

Padahal apabila kita hendak mengamati masalah kejahatan secara komprehensif, kita tidak boleh mengabaikan peranan korban dalam terjadinya kejahatan. Bahkan, apabila memerhatikan pada aspek pencarian kebenaran materiil sebagai tujuan yang akan dicapai dalam pemeriksaan suatu kejahatan, peranan korban pun sangat strategis. Dengan demikian, sedikit banyak menentukan dapat tidaknya pelaku kejahatan memperoleh hukuman yang setimpal dengan perbuatan yang dilakukannya.

Tidak berlebihan apabila selama ini berkembang pendapat yang menyebutkan bahwa korban merupakan asset yang penting dalam upaya menghukum pelaku kejahatan.

Pada sebagian besar kasus-kasus kejahatan, korban sekaligus merupakan saksi penting yang dimiliki untuk menghukum pelaku kejatahan. Sayangnya, dalam kerangka pemeriksaan suatu perkara di mana korban merupakan saksi bagi pengungkapan suatu kejahatan. Korban hanya diposisikan sebagai instrument dalam rangka membatu aparat penegak hukum tunuk menghukum si pelaku, dan tidak pernah berlanjut pada apa yang dapat Negara serta aparat penegak hukum lakukan untuk sei korban, sehingga penderitaan (kerugian) yang diderita korban dapat dipulihkan seperti keadaan sebelum terjadinya kejahatan yang menimpa dirinya.

Apabila dikaji, dilupakannya persoalan korban tersebut disebabkan antara lain karena: 
1. Masalah kejahatan tidak dilihat, dipahami menurut proporsi yang sebenarnya secara multi dimensional;

2. Kebijakan penanggulangan kejahatan (criminal policy) yang tidak didasarkan pada konsep yang integral dengan etiologi criminal;

3. Kurangnya pemahaman bahwa masalah kejahatan merupakan masalah kemanusiaan, demikian pula masalah korban.

Perhatian kalangan ilmuwan terhadap persoalan korban dimulai pada saat Hans von Hentig pada tahun 1941 menulis sebuah makalah yang berjudul "Remark on the interaction of perpetrator and victim" (Keterangan pada interaksi pelaku dan korban). Tujuh tahun kemudian beliau menerbitkan buku yang berjudul The criminal and his victim (Para kriminal dan korbannya) yang menyatakan bahwa korban mempunyai peranan yang menentukan dalam timbulnya kejahatan, mempelajari hubungan antara pelaku dan korban (victim-offender relationship) dari aspek penderitaan korban dan aspek korban sebagai pemicu dan mengakibatkan kejahatan.

Dalam bukunya yang berjudul The criminak and his victim tersebut, von Hentig membagi enam kategori korban dilihat dari keadaan psikologis masingmasing, yaitu :

a. The depressed, who are weak and submissive (The depresi, yang lemah dan patuh);

b. The acguasitive, who succumb to confidence games and racketeers (Acguasitive, yang menyerah pada permainan keyakinan dan pemeras);

c. The wanton, who seek escapimin forbidden vices (The nakal, yang mencari keburukan dilarang escapimin);

d. The lonesome and heartbroken, who are susceptible to theft and fraund (Para kesepian dan patah hati, yang rentan terhadap pencurian dan fraund);

e. The tormentors, who provoke violence, and (Para penyiksa, yang memprovokasi kekerasan) dan ;

f. The blocked and fightings, who are unable to take normal defensive measures (Diblokir dan pertempuran-pertempuran, yang tidak mampu untuk mengambil langkah-langkah defensif yang normal). 
Pada tahun 1947 atau setahun sebelum buku von Hentig terbit, Mendelsohn menulis sebuah makalah dengan judul "New bio-psycho-sosial borizons:Viktimology." Pada saat inilah menjamin Mendelsohn, seorang pengacara di Jerusalem dianggap orang yang pertama kali mempergunakan istilah victimology dalam bukunya yang berjudul "Revue Internationale de Criminologie et de Police Technique."

Pembahasan mengenai Korban oleh von Hentig dan Mendelsohn kemudian diikuti oleh sarjana-sarjana lain di antaranya seperti Ellenberger (1954), yang melakukan suatu studi tentang hubungan psikologis antara penjahat dengan korban, bersama dengan H.Mainheim (1965), Schafer (1968), dan Fiseler (1978).

Kemudian, pada tahun 1949 W.H. Nagel juga melakukan berbagai pengamatan mengenai subjek ini dalam tulisannya berjudul "de Criminaluteit van Oss, Groningen." Dan sepuluh tahun kemudian dapat dikatakan viktimologi menjadi isu yang menarik dalam perkembangan ilmu pengetahuan.

Pada tahun 1959 P.Cornil dalam penelitiannya menyimpulkan bahwa si korban patut mendapatkan perhatian yang lebih besar lagi dari kriminologi dan viktimologi harus diperhatikan dalam membuat kebijakan criminal dan juga dalam pembinaan para pelaku kejahatan. Baik Cornil maupun Nagel memperluas wilayah bahasan kriminologi sampai masalah korban.

Perhatian terhadap korban kejahatan akhirnya diwujudkan dalam suatu symposium internasional di Jerusalem pada tanggal 5-6 September 1973.

Dalam symposium di Jerusalem ini berhasil dirumuskan beberapa kesimpulan, yaitu: viktimologi dapat dirumuskan sebagai studi ilmiah mengenai para korban, dan kriminologi telah diperkaya dengan suatu orientasi viktimologi.

Symposium kedua diadakan di Boston, pada tanggal 5-9 September 1976. Viktimologi dianggap penting karena dapat membantu menambah kecerahan dalam menghadapi penjahat dan korbannya. Studi lebih lanjut tentang viktimologi juga telah dilakukan dalam bentuk Postgraduate Course on the Victim of Crime in The Criminal Justice System (Pascasarjana kursus pada Korban Kejahatan di Sistem Peradilan Pidana) dan telah dua kali dilakukan di Dubrovnick, Yugoslavia. Setelah mengalami berbagai kesulitan pada saat diselenggarakannya symposium yang 
kedua di Boston, maka pada tahun 1977 didirikanlah World Society of Viktimology. Wold Society of Viktimology (WSV) dipelopori oleh Schneider dan Drapkin. Perjalanan panjang untuk menghasilkan suatu prinsip-prinsip dasar tentang perlindungan korban memang sangat terasa. Sekalipun demikian, cita-cita tersebut akhirnya dapat terwujud pada saat diadakan kongres di Milan, Italia pada tanggal 26 Agustus sampai dengan 6 September 1985 dengan nama Congress on the Prevention of Crime and the Treatment of Offenders (Kongres tentang Pencegahan Kejahatan dan Perlakuan terhadap Pelanggar), yang menghasilkan beberapa prinsip dasar tentang korban kejahatan dan penyalahgunaan kekuasaan yang selanjutnya diadopsi oleh Perserikatan Bangsa-Bangsa pada tanggal 11 Desember 1985 dalam suatu deklarasi yang dinamakan Declaration of Basic Principles of Justice for Victims of Crime and Abuse of Power (Deklarasi PrinsipPrinsip Dasar Keadilan bagi Korban Kejahatan dan Penyalahgunaan Kekuasaan).

Dari gambaran di atas dapat disimpukan bahwa viktimologi yang pada mulanya berwawasan sempit sebagaimana dikemukakan oleh von Hentig dan Mendelsohn. Selanjutnya viktimologi yang berinklusif wawasan hak-hak asasi manusia (juga disebut the new victimology) dikembangkan oleh Elias, kemudian diperluas lagi sehingga mencakup penderitaan manusia (kemanusiaan) oleh Separovic.

New Victimology ini bertujuan untuk :

1. Menganalisis berbagai aspek yang berkaitan dengan korban;

2. Berusaha untuk memberikan penjelasan sebab musabab terjadinya victimisasi; dan

3. Mengembangkan system tindakan guna mengurangi penderitaan manusia.

Sejak dimulainya studi tentang kepribadian korban yang dilakukan oleh Benyamin Mendelsohn pada tahun 1937, viktimologi sebagai applied science bagi hukum pidana dan kriminologi terus berkembang. Bahkan sampai saat ini telah dilakukan lima kali simposium internasional tentang Viktimologi dan terakhir di Zagreb, Yugoslavia pada tahun 1985, disamping pertemuan-pertemuan ilmiah lain yang diselenggarakan di berbagai Negara. 
Memang harus diakui bahwa kajian mengenai viktimologi relative kurnag diminati di kalangan praktisi hukum sehingga dari waktu ke waktu perkembangannya jauh tertinggal dibandingkan dengan kajian lainnya seperti kriminologi, penintensier, dan sebagainya. Terbukti bidang viktimologi miskin dengan litratur serta kajian-kajian ilmiah lainnya. Hal ini terjadi karena dalam penanganan perkara pidana perhatian yang diberikan kepada pelaku lebih banyak dari pada korban sebagaimana Pressell berpendapat:

"Victim was a forgotten figure in the study of crime. Victims of assaults, robbery, theft, and other offenceses were ignored while police, courts, and academicians concentrated on known violators." Artinya (makna): "Korban adalah seorang tokoh dilupakan dalam studi kejahatan. Korban serangan, perampokan, pencurian, dan offenceses lainnya diabaikan sementara polisi, pengadilan, dan akademisi berkonsentrasi pada pelanggar diketahui. “

Sekalipun demikikian, tidak berarti bahwa viktimologi merupakan bidang yang tidak memerlukan perhatian yang serius dibandingkan dengan bidang kajian lainnya karena melalui viktimologi akan dapat diperoleh masukan dalam menghadapi dan menanggulangi masalah kejahatan yang semakin hari semakin meningkat.

\section{c. Ruang Lingkup Viktimologi}

Viktimologi meneliti topik-topik tentang korban, seperti: peranan korban pada terjadinya tindak pidana, hubungan antara pelaku dengan korban, rentannya posisi korban dan peranan dalam system peradilan pidana. Selain itu, menurut Muladi viktimologi merupakan suatu studi yang bertujuan untuk:

1. Menganalisis berbagai aspek yang berkaitan dengan korban;

2. Berusaha untuk memberikan penjelasan sebab musabab terjadinya viktimisasi;

3. Mengembangkan sistem tindakan guna mengurangi penderitaan manusia.

Menurut J.E Sahetapy, ruang lingkup viktimologi meliputi bagaimana seseorang (dapat) menjadi korban yang ditentukan oleh suatu victim yang tidak selalu berhubungan dengan masalah kejahatan, termasuk pula korban kecelakaan, 
dan bencana alam selain dari korban kejahatan dan penyalahgunaan kekuasaan. Namun, dalam perkembangannya di tahun 1985, Separovic memelopori pemikiran agar viktimologi khusus mengkaji korban karena adanya kejahatan dan penyalah gunaan kekuasaan dan tidak mengkaji korban karena musibah atau bencana alam karena korban bencana alam di luar kemauan manusia (out of man's will).

Kejahatan yang mengakibatkan korban sebagai obyek sebagai kajian viktimologi semakinluas setelah kongres PBB kelima di Jeneva Tahun 1975, kongres Keenam Tahun 1980 di Caracas, yang meminta perhatian bahwa korban kejahatan dalam cakupan viktimologi bukan hanya kejahatan konvensional seperti; pemerasan, seperti terorisme, pembajakan, dan kejahatn kerah putih. ${ }^{30}$

Dari hasil kongres PBB Kelima di Jeneva Tahun 1975 menghasilkan kesepakatan untuk memerhatikan kejahatan yang disebut sebagai crime as business, yaitu kejahatan yang bertujuan keuntungan materil melalui kegiatan dalam bisnis dan industry yang pada umumnya dilakukan secara terorganisasi dan dilakukan oleh orang-orang yang mempunyai kedudukan terpandang dalam masyarakat, seperti, pencemaran lingkungan, perlindungan konsumen, perbankan dan kejahatan-kejahatan lain yang biasa dikenal sebagai, organized crime, white collar crime, dan korupsi. Sedangkan dalam kongres PBB Keenam Tahun 1980 di Caracas dinyatakan bahwa kejahatan-kejahatan yang sangat membahayakan dan merugikan, bukan hanya kajahatn terhadap nyawa orang, harta benda, akan tetapi penyalah gunaan kekuasaan juga termasuk kejahatn yang sangat membahayakan kehidupan masyarakat dan bangsa dan Negara.(abuse power), sedangkan Kongres ketuju yaitu pada Tahun 1985 yaitu menghasilkan kesepakatan untuk memerhatikan kejahatan-kejahatan tertentuyang dianggap atau dipandang membahayakan seperti; Economi craime, anvironmentak offences.Ilegal trafficking in drugs,terrorism, apartheid, and industrial crime.

\section{d. Korban dan Kejahatan "Meliputi beberapa hal"}

1. Korban,

2. Tipologi korban,

\footnotetext{
30 Julaiddin. Viktimologi op. cit., hlm.. 51-52.
} 
3. Hak dan kewajiban korban,

4. Kewajiban korban,

5. Kejahatan,

6. Hubungan korban kejahatan dengan pelaku kejahatan,

Untuk itu penulis memberikan penjelasan dan pengertian secara harfiah agar dapat memahami dengan ketajaman pemikiran bagi sipembaca buku ini. Dengan ini beberapa hal yang sangat penting untuk mengetahui segala sesuatu kejahatan dan korban kejahatan secara ilmia dan secara ketegasannya baik secara undangundang maupun secara hukum. dengan demikian maka diperlukannya keterangan yang jelas, antara lain sebagai berikut;

1. Korban , pengertian korban sangatlah penting diberikan dalam pembahasan ini adalah untuk sekedar membantu dalam menetukan secara jelas batas-bats yang dimaksud oleh pengertian tersebut sehinghga dapat memberikan kesamaan cara pandang. Korban suatu kejahatan tidaklah selalu berupa individu atau orang perorangan akan tetapi bias juga berupa kolompok orang, masyarakat, atau juga badan hukum. bahkan pada kejahatan tertentu, korbannya bisa juga berasal dari bentuk kehidupan lainnya seperti tumbuhan, hewan, ataupun ekosistim. Korban semacam ini lazim kita temui dalam kejahatan lingkungan, baik dalam lingkungan daratan, hutan lindung, maupun dalam lingkungan kelautan.

Di berbagai macam pengertian korban banyak dikemukakan oleh para ahli maupun yang bersumber dari konvensi-konvensi internasional yang membahas mengenai korban kejahatan, sebagian dintara para ahli tersebut adalah;

a. Aref Gosita menurutnya, Korban adalah mereka yang mengalami penderitaan baik menderita secar jasmani, rohaniah, sebagai tindakan lain yang mencari pemenuhan kepentingan diri sendiri atau orang lain yang bertentangan dengan kepentingan hak asasi pihak yang dirugikan.

b. Ralph de Sola, ,menurutnya, Korban (victim) adalah " person who has injured mental or physical suffering, loss of property or death resulting from an actual or attemted criminal offense committed by another." (Artinya) "Orang yang telah melukai fisik atau mental penderitaan, 
kehilangan harta benda atau kematian akibat dari tindak pidana yang sebenarnya atau attemted dilakukan oleh yang lain."

c. Cohen, menurutnya, Korban (victim) adalah " hwose pain and suffering have been negletedby the state while it spends immense to hunt down and punish the offender hwo responsible for that pain and suffering." (Artinya) "Rasa sakit dan penderitaan hwose telah negletedby negara sementara itu menghabiskan besar untuk memburu dan menghukum pelaku hwo bertanggung jawab untuk itu rasa sakit dan penderitaan."

d. Z.P. Zeparovic, memberikan pandangan bahwa, Korban (victim) adalah “ ..the person who are theretened, injured or destroyed by an actor omission of another (mean, structure, organization, or institution) and conseguently; a victim would be any one who has suffered from or been theatened by a punishable act (not only criminal act but also another punishable act as misdemeanors, economic offence, non fulfillment of work duties) or an accidents. Suffering may be caused by another man or another structure, where people are also involved." (Artinya) ".. Orang yang theretened, terluka atau dihancurkan oleh kelalaian aktor lain (ratarata, struktur, organisasi, atau lembaga) dan conseguently, korban akan menjadi salah satu yang menderita atau telah theatened oleh tindak pidana (tidak hanya tindak pidana, tetapi juga yang lain tindak pidana sebagai pelanggaran ringan, pelanggaran ekonomi, pemenuhan non tugas kerja) atau kecelakaan. Penderitaan bisa disebabkan oleh orang lain atau struktur lain, di mana orang juga terlibat. "

e. Muladi, menurutnya, Korban (victim) adalah orang-orang yang baik secara individu maupun kolektif telah menderita kerugian, termasuk kerugian fisik atau mental melalui perbuatan atau emosi yang melanggar hukum pidana di masing-masing Negara, termasuk penyalahgunaan kekuasaan.

f. Undang-Undang NO. 23 Tahun 2004 tentang penghapusan kekerasan dalam rumah tangga. Maksudnya dalam artian (viktimologi) korban tersebut adalah “ orang yang mengalami kekerasan dan/atau ancaman kekerasan dalam lingkup rumah tangga." 
g. Undang-Undang No.27 Tahun 2004 tentang komisi kebenaran dan rekonsiliasi. Maksudnya dalam artian ini adalah "Korban adalah orang perseorangan atau kolompok orang yang mengalami penderitaan, baik fisik, mental, maupun emosional, kerugian ekonomi,atau mengalami pengabvaian hak-hak, pengurangan hak-hak, atau penghapusan hak-hak dasarnya, sebagai akibat pelanggaran hak asasi manusia yang berat, dan yang termasuk korban dalam hal ini adalah ahli waris.

h. Poraturan Pemerintah Nomor 2 Tahun 2002 Tentang Tata Cara Perlindungan Terhadap Korban dan Saksi dalam Pelanggaran Hak Asasi Manusia yang Berat." Maksud dalam pengertian Korban (victim) disini adalah orang perseorangan atau kelompok orang yang mengalami penderitaan sebagai akibat pelanggaran hak asasi manusia yang berat, memerlukan perlindungan fisik dan mental dari ancaman, gangguan, terror dan kekerasan pihak manapun juga, agar dalam menjalankan aktifitas untuk pemenuhan kehidupan lebih nyaman dan tenteram dari segala sesuatu yang dapat menimbulkan kerugian dari para pihak, baik itu pihak masyarakat, pemerintah, maupun hukum itu sendiri.

i. Deklarasi PBB dalam "The Declaration of Basic Principles Of Justice For Victims of crime and abuse power 1985. Memberikan pengertian yang lebih luas yaitu "Victims means person who, individually or collectively, have suffered harm, including physical or mental injury, emotional suffering, economic loss or subtansial impairmen of their fundamental rights, through actrs or omissions that are in violation of criminal laws operative withim member states, including those laws proseribing criminal abuse power (Artinya) "Korban berarti orang yang secara individu atau kolektif, telah menderita kerugian, termasuk luka fisik atau mental, penderitaan emosional, kerugian ekonomi atau impairmen subtansial dari hak-hak dasar mereka, melalui actrs atau kelalaian yang merupakan pelanggaran hukum pidana negara-negara anggota withim operasi, termasuk hukum-hukum proseribing penyalahgunaan kekuasaan pidana 
Untuk itu dengan mengacu pada pengertian-pengertian tersebut diatas maksudnya adalah dalam pengertian korban yang mana dalam hal ini dapat dilihat, bahwa korban pada dasarnya tiudak hanya orang perorangan atau kelompok yang secara langsung menderita akibat dari perbuatan-perbuatan yang menimbukan kerugian/penderitaan bagi diri sendiri/kelompoknya, bahkan lebih luas lagi, termasuk didalamnya keluarga dekat atau tanggungan langsung dari korban dan orang-orang yang mengalami kerugian ketika membantu korban mengatasi penderitaannya atau untuk mencegah viktimisasi.

Dengan pandangan yang sangat tajam menurut Separovic bahwa mengenai kerugian korban yang harus diperhitungkan adalah tidak harus selalu berasal dari kerugian karena menjadi korban kejahatan, tapi kerugian atas terjadinya pelanggaran atau kerugian yang ditimbulkan karena tidak melaksanakan atau melakukan suatu pekerjaan walaupun yang disebut terakhir lebih banyak merupakan persoalan perdata. Akan tetapi pihak pihak yang dirugikan tetap saja termasuk dalam kategori korban, karena ia mengalami kerugian baik secara materil maupun secara mental.

2. Tipologi Korban adalah merupakan perkembangan ilmu viktimologi selain mengajak masyarakat untuk lebih memperbaiki dan atau memperhatikan posisi korban, dan juga harus dapat memilah milah jenis korban sehingga muncullah berbagai macam dan jenis korban antara lain adalah sebagai berikut; "Tipologi kejahatan dapat ditinjau dari dua perspektif", yaitu;

a. Ditinjau dari perspektif tingkat keterlibatan korban dalam terjadinya kejahatan. Melalui kajian perspektif ini, penulis mengutip kalimat yang telah dituangkan oleh ahli hukum yaitu"Elzzat Abdel Fatta" meneyebutkan beberapa tipopologi korban antara lain adalah;

1. Nonparticipating victims adalah mereka yang menyangkal/menolak kejahatan dan penjahat tetapi tidak turut berpartisipasi dalam penanggulangan kejahatan;

2. Latent or predisposed victims adalah mereka yang mempunyai karakter tertentu cendrung menjadi korban pelanggaran tertentu; 
3. Provokatif victims adalah mereka yang menimbulkan kejahatan atau pemicu kejhatan;

4. Particapcing victims adalah mereka yang tidak menyadari atau memiliki prilaku lain sehingga memudahkan dirinya menjadi korban;

5. False victim adalah mereka yang menjadi korban, karena dirinya ingin menjadi kaya namun tidak memikirkan dampak kedepannya, sehingga dirinya sendiri menjadi korban atas perbuatan yang telah dilakukan tanpa memikirkan sebab akiabt yang akan menimpa dirinya sendiri atau karena kebodohannya.

b. Di tinjau dari perspektif tanggung jawab korban itu sendiri, ahli hukum "Stepen Schafer" mengemukakan bahwa tipologi korban menjadi tujuh (7) bentuk antara lain adalah sebagai berikut; ${ }^{31}$

1. Unrelated victims adalah mereka yang tidak ada hubungan dengan sipelaku dan menjadi korban karena memang potensial. Untuk itu, dari aspek tanggung jawab sepenuhnya berada dipihak korban ;

2. Proactive victims adalah merupakan korban yang di sebabkan peranan korban untuk memicu terjadinya kejahatan. Karena itu, dari aspek tanggung jawab terletak pada diri korban dan pelaku secara bersamasama;

3. Participacing victims adalah pada hakikatnya perbuatan korban tidak disadari dapat mendorong pelaku untuk dapat melakukan kejahatan. Misalnaya, mengambil uang ke bank dalam jumlah yang besar tanpa pengawalan dari pihak yang berwajib (Polsi, TNI), kemudian dibungkus dengan kertas Koran atau pelastik dimana hal tersebut dapat mengungdang terjadinya kehajatan, perampokan, penodongan, perampasan, aspek ini adalah merupakan tanggung jawab dari pada pelaku kejahatan namun pada intinya adalah korban sendiri memberikan suatu peluang untuk terjadinya tindak pidana.

4. Biologically weak victim adalah kejahatan yang disebabkan adanaya keadaan fisik korban seperi wanita, anak-anak, dan manusia lanjut usia

\footnotetext{
${ }^{31}$ Mulyadi L. Kapita selekta Hukum Pidana Kriminologi dan Viktimologi. Penerbit. Djambatan, Dempasar Tahun 2003. hlm, 123-125.
} 
(manula) merupakan potensial korban kejahatan. Ditinjau dari pertanggung jawabannya terletak pada masyarakat atau pemerintah setempat karena tidak dapat memberikan perlindungan kepada korban yang tidak berdaya.

5. Socially weak victims adalah korban yang tidak diperhatikan oleh masyarakat bersangkutan seperti gelandangan dengan kedudukan sosial yang lemah. Untuk itu, pertanggungjawabannya secara sepenuhnya terletak pada pelaku kejahatan atau penjahatnya dan masyarakat itu sendiri.

6. Self victimizing victims adalah korban kejahatan yang dilakukan oleh sendiri (korban semu) atau kejahatan tanpa korban. Untuk itu pertanggungjawabannya sepenuhnya terletak pada korban sekaligus sebagai pelaku kejahatan.

7. Political victims adalah korban karena lawan politiknya. Secara sosiologis, korban ini tidak dapat dipertanggung jawabkan kecuali adanya perubahan konstelasi politik.

c. Selain pengelompokan diatas,masih ada pengolompoka korban menurut

Sellin dan Wolfgang, yaitu sebagai berikut;

1. Primary victimization, yaitu korban berupa individu perorangan (bukan kolompok),

2. Secondary victimization, yaitu korban kolompok, misalnya badan hukum,

3. Tertiary victimization, yaitu korban masyarakat luas,

4. No victimization, yaitu korban yang tidak dapat di ketahui, misalnya konsumen yang tertipu dalam menggunakan produksi.

\section{Hak dan Kewajiban Korban}

Setiap hari masyarakat banyak memperoleh informasi tentang berbagai peristiwa kejahatan, baik yang diperoleh dari berbagai media cetak, media elektronika. Peristiwa-peristiwa kejahatan tersebut tidak sedikit menimbulkan 
berbagai penderitaan/kerugian korban maupun keluarganya. dimana hal tersebut apabila kita analisis lebih jauh kedepan, maka peritiwa tersebut seharusnya tidak harus terjadi namun terkadang korban sendiri menjadi pemicu suatu peristiwa yang menjadikan korban dirinya sendiri, untuk itu setelah mereka menyadari peristiwa tersebut maka pihak korban mencari jalan untuk perlindungan diri sendiri maupun untuk pihak keluarganya. Guna memberikan rasa aman, nyaman bagi masyarakat dalam beraktifitas, tentunya kejahatan-kejahatan ini perlu ditanggulangi baik melalui pendekatan yang sifatnya prefentif, reprensif, dan semuanya harus ditangani dengan secara professional oleh suatu lembaga yang lebih berkompoten, agar tidak terjadi suatu diskriminatif terhadap hak-hak, baik itu korban dari suatu kejahatan maupun yang diduga melakukan perbutan kriminal.

Berkaitan dengan korban kejahatan perlu dibentuk suatu lembaga yang khusus menanganinya. Namun, pertama-tama yang perlu disampaikan terlebih dahulu suatu informasi yang memadai mengenai hak-hak apa saja yang dimiliki oleh korban dan keluarganya, apabila dikemudian hari mengalami kerugian atau penderitaan sebagai akibat dari sutu kejahatan yang menimpa dirinya. Untuk itu, setiap adanya perbuatan yang melanggar ketentuan hukum pidana baik itu pelanggaran ringan ataupun berat maka sangat diperlukan tentang kejelasan dalam suatu penegakan hukum, agar tidak menjadi Presiden buruk bagi penegakannya, oleh karena itu hak-hak dari korban selalu terabaikan begitu saja tidak memandang tentang hak-hak setiap warga Negara khususnya warga Negara Republik Indonesia, bahwa setiap insan manusia yang ada dimuka bumi ini harus perlu kehidupan dan penghidupan sebagai mana yang telah ditentukan dalam Undang-Undang Dasar Negara Republik Indonesia Pasal 27 ayat (2) dan untuk itu sebagai warga Negara dengan amanat Pasal 27 ayat (2) tersebut kita harus menjunjung tinggi demi penegakkannya, agar setiap warga negara yang mencari keadialan selalu mempunyai kesamaan dan kedudukan dihadapan hukum dengan tidak terkecuali dan tidak membedakan antara yang kaya dan simiskin, karena fakta-fakta menunjukan bahwa sikayalah yang berkuasa sedangkan simiskin dijadikan kambing hitam. Oleh karena itu penulis memberikan salah santu contoh kasus yang paling sering dialami bagi setiap orang, dimana hak-hak mereka terinjak-injak, 
teraniyaa, terintimidasi serta terjolimi yaitu; "seorang ibu yang melahirkan anaknya dengan begitu sulit untuk mempertahankan hidup antara dua napas yang berbeda, dimana pertarungan nyawa tersebut tidak dapat dibayar oleh harta benda, walaupun nilainya miliaran rupiah karena kalaulah tiada baru terasa, namun bila itu masih ada sisah-sisah pernapasan maka timbullah suatu kosombongan, bahwa mereka akan mampu menegendalika hawa nafsunya, akan tetapi bukti nyata mempertontonkan kapada kita semua bahwa seorang ibu membunuh anak kandungnya sendiri oleh karena faktor yang harus tidak perlu terjadi. Bukankah itu adalah suatu pengerbanan yang sia-sia, dengan tidak mempertimbangkan perjuangannya maka spontanitas seorang ibu harus menjadi korban atas perbuatannya sendiri." Contoh kasus yang secara nyata dan disaksikan oleh masyarakat banyak yaitu adalah seorang ibu yang kaya raya menuduh majikannnya bahwa ia telah mencuri emas dan piring, namun tuduhannya itu adalah salah, akibat salahnya penyelidikan maka sang miskin menjadi korban yang bukan pebuatannya. Untuk itu dengan penulisan buku ini yang mengkaji tentang ilmu Viktimologi dan Kriminologi maka diharapkan agar para penegak hukum yaitu: Polisi, Jaksa, Hakim, Advokat untuk menganalisis segala sesuatu sebelum korban berjatuhan akibat kesalahan atau kelalaian yang telah dilakukan.

Hak merupakan sesuatu yang bersifat pilihan (optimal) artinya bias diterima oleh pelaku bisa juga tidak, tergantung kondisi yang memengaruhi korban baik yang sifatnya interna maupun eksternal.

Tidak jarang ditemukan seseorang yang mengalai penderitaan (fisik, mental, atau materiil) akibat suatu tindak pidana yang menimpa dirinya, tidak mempergunakan hak-hak yang seharusnya diterima karena berbagai alasan, misalnya perasaan takut dikemudian hari masyarakat menjadi tahu kejadian yang menimpa dirinya (karena kejadian ini merupakan aib bagi diisinya maupun keluarganya) sehingga lebih baik korban menyembunyikannya, atau korban menolak untuk mengajukan ganti kerugian karena dikhawatirkan prosesnya akan menjadi semakin panjang dan berlarut-larut yang dapat dlberakibatkan pada timbulnya penderitaan yang berkepanjangan. 
Sekalipun demikian, tidak sedikit korban atau keluarga mempergunakan hakhak yang telah disediakan. Ada beberapa hak umum yang disediakan bagi korban atau keluarga korban kejahatan, yang meliputi:

a. Hak untuk memperoleh ganti kerugian atas penderitaan yang dialaminya. Pemberian ganti kerugian ini dapat diberikan oleh pelaku atau pihak lainnya, seperti Negara atau lembaha khusus yang dibentuk untuk menagani masalah ganti kerugian korban kejahatan;

b. Hak untuk memperoleh pembinaan dan rehabilitasi;

c. Hak untuk memperoleh perlindungan dari ancaman pelaku;

d. Hak unuk memperoleh bantuan hukum;

e. Hak untuk memperoleh kembali hak (harta) miliknya;

f. Hak untuk memperoleh akses atas pelayanan medis;

g. Hak untuk diberitahu bila pelaku kejahatan akan dikeluargkan dari tahanan sementara, atau bila pelaku buron dari tahanan.

h. Hak untuk memperoleh infromasi tentang penyidikan polisi berkaitan dengan kejahatan yang menimpa korban;

i. Hak atas kebebasan pribadilkerahasian pribadi, seperti merahasiakan nomor telepon atau identitas korban lainnya.

Berdasarkan Pasal 10 dari Undang-undang nomor 23 Tahun 2004 tentang Penghapusan Kekerasan dalam Rumah Tangga (KDRT), korban berhak mendapatkan:

a. Perlindungan dari pihak keluarga, kepolisian, kejaksaan, pengadilan, advokat, lembaga social, atau pihak lainnya baik sementara maupun berdasarkan penetapan perintah pelindungan dari pengadilan;

b. Pelayanan kesehatan sesuai dengan kebutuhan medis;

c. Penangan secara khusus berkaitan dengan kerahasian korban;

d. Pendampingan oleh pekerja social dan bantuan hukum pada setiap tingkat proses pemeriksaan sesuai dengan ketentuan peraturan perundangundangan;

e. Pelayanan bimbingan rohani. 
Deklarasi Perserikatan Bangsa-Bangsa Nomor. 40/A/Res/34 Tahun 1945 juga telah menetapkan beberapa hak korban (saksi agar lebih mudah memperoleh akses keadilan, khususnya dalam proses peradilannya, yaitu:
a. Compassion, respect and c vrecognition;
b. Receive information and ecplanation about the progress of the case;
c. Provide information;
d. Providing proper assistance;
e. Protection of privacy and physical safety;
f. Restution and compensation;
g. To acces to the mechanism of Justice system.

\section{Kewajiban Korban}

Sekalipun hak-hak korban kejahatan telah tersedia secara memadai, mulai dari hak atas bentuk keuangan (financial) hingga hak atas pelayanan medis dan bantuan hukum, tidak berarti kewajiban dari korban kejahatan diabaikan eksestensinya karena melalui peran korban dan keluarnya diharapkan penanggulangan kejahatan dapat dicapai secara signifikan.

Untuk itu, ada beberapa kewajiban umum dari korban kejahatan, antara lain:

a. Kewajiban untuk tidak melakukan upaya main hakim sendiri balas dendam terhadap pelaku (tindakan pembalasan);

b. Kewajiban untuk mengupayakan pencegahan dari kemungkinan terulangnya tindak pidana:

c. Kewajiban untuk memberikan informasi yang memadai mengenai terjadinya kejahatan kepada pihak yang berwenang;

d. Kewajiban untuk tidak mengajukan tuntuan yang terlalu berlebihan kepada pelaku;

e. Kewajiban untuk menjadi saksi atas suatu kejahatan yang menimpa dirinya, sepanjang tidak membahayakan bagi korban dan keluarganya;

f. Kewajiban untuk membantu berbagai pihak yang berkepentingan dalam upaya penanggulangan kejahatan; 
g. Kewajiban untuk tersedia dibina atau membina diri sendiri untuk tidak menjadi korban lagi.

\section{Kejahatan}

Pengertian kejahatan (crime) sangatlah beragam, tidak ada definisi baku yang didalamnya mencakup semua aspek kejahatan secara komprehensif. Ada yang memberikan pengertian kejahatan dilihat dari aspek yuridis, sosiologi, maupun kriminologi.

Munculnya perbedaan dalam negartikan kejahatan dikarenakan prespektif orang dalam memandang kejahatan sangat beragam, disamping tentunya perumusan kejahatan akan sangat dipengaruhi oleh jenis kejahatan yang akan dirumuskan. Sebagai contoh pengertian kejahatan korporasi (corporate crime). Jenis kejahatan ini acapkali digunakan dalam berbagai konteks dan penamaan. Tidaklah mengherankan kalau di Amerika Serikat, dimana setiap Negara bagian menyusun perundang-undangan, terdapat lebih kurang 20 perumusan yang bertalian dengan kejahatan korporasi.

Secara etimologi kejahatan adalah bentuk tingkah laku yang bertentangan dengan moral kemanusian. Kejahatan merupakan suatu perbuatan atau tingkah laku yang sangat ditentang oleh masyrakat dan paling tidak disukai oleh rakyat.

Black menyatakan bahwa crime is a social harm that the law makes punishable, the breach of a legal duty treated as the subjectmatter of a criminal proceeding, sedangkan Huge D.barlaw sebagaimana dikutip oleh Topo Santoso dan Eva A.Zulfa menyebutkan kejahatan adalah a human act that violates the criminal law.

Van Bemmelen merumuskan kejahatan adalah tiap kelakukan yang tidak bersifat susila dan merugikan, yang menimbulkan begiru banyak ketidak tenangan dalam suatu masyarakat tertentu sehingga masyarakat itu berhak untuk mencelanya dan menyatakan penolaknya atas kelakuan itu dalam bentuk nestapa dengan sengaja diberikan karena kelakuan tersebut.

Jika dikaitkan dengan kejahatan-kejahatan yang terdapat dalam Kitab Undang-Undang Hukum Pidana, perumusan kejahatan menurut Kitab Undang- 
Undang Hukum Pidana adalah semua bentuk perbuatan yang memenuhi perumusan ketentuan-ketentuan Kitab Undang-Undang Hukum Pidana.

Sekalipun perumusan kejahatan sangat beragam namun pada intinya memiliki kesamaan unsure, dengan mengacu pada pendapat Kimball, unsure-unsur (elemen) kejahatan itu adalah:

a. An actor

b. With a guilty mind (mens rea);

c. Who causes;

d. Harm;

e. In particular way or setting, and;

f. A law maker hwo has decreed that these circumstances expose the actor to imposition of fine, imprisonment, or death as a penalty.

Pada awalnya, kejahatan hanyalah merupakan "cap" yang diberikan masyarakat pada perbuatan-perbuatan yang dianggap tidak layak atau bertentangan dengan norma-norma atau kaidah-kaidah yang berlaku dalam masyrakat. Dengan demikian, ukuran untuk menentukan apakah suatu perbuatan merupakan kejahatan atau bukan adalah "apakah masyarakat secara umum akan mencerita kerugian secara ekonomis serta perbuatan tersebut secara psikologis merugikan sehingga di masyarakat muncul rasa tidak aman dan melukai perasaan?”.

Karena ukuran pertama dalam menentukan apakah suatu perbuatan merupakan kejahatan atau bukan adalah norma-norma yang hidup dan dianut oleh masyarakat setempat, tentu sukar untuk menggolongkan jenis-jenis perbuatan yang dapat disebut dengan kejahatan.

Contoh dalam budaya Madura, membunuh orang sebagai bentuk balas dendam yang lazim disebut Carok, tentunya lebih merupakan sebuah upaya membela harkat dan martabat keluarga dari pada disebut sebagai pembunuhan sehingga ketika Carok dilakukan oleh seseorang, pihak keluarga pelaku menanggap tindakan tersebut sebuah sikap "pahlawan".

Namun, kita tidak boleh di daya dan digiring kearah pendikotomian antara budaya dan kejahatan. Kejahatan tetaplah kejahatan tidak boleh dilegalkan dengan 
mengatasnamakan adat dan budaya karena kejahatan tetap saja merupakan suatu perbuatan yang dapat menimbulkan kerugian bagi masyarakat.

Besarnya dampak yang ditimbulkan oleh aksi kejahatan yang selalu menimbulkan korban, baik secara financial atau materiil secara fisik maupun psikis, tampak jelas digambarkan oleh Von Hentig dalam bukunya crime, causes, and conditions (1947), dikatakan bahwa pada tahun 1941 saja, kerugian secra materil diderita oleh 28.500.000 penduduk dari 231 kota di Amerika Serikat bisa mencapai \$US 13.000.000 kerugian ini pun hanya merupakan angka dari tiga jenis kejahatan saja, yaitu perampokan, pencurian dengan kekerasan, serta pencurian biasa. Angka ini belum lagi ditambah dengan biaya yang hatus dikeluarkan untuk membiayai tugas kepolisian, kejaksaan serta kehakiman beserta aparatur lainnya yang berhubungan.

Sebagai perbandingan, di Indonesia akibat dari terjadinya kasus peledakan bok di Legian Bali pada 12 Oktober Tahun 2002 (Bom Bali I), kerugian yang diderita adalah korban jiwa lebih kurang 192 orang, korban luka-luka sebanyak kurang lebih 161 orang, menghancurkan bangunan Sari Club dan Paddy's Pub, fasilitas publik atau fasilitas umum berupa kerusakan jaringan telepon, listrik dan saluran air PDAM. Kerugian ini belum termasuk pembatalan paket-paket wisata asing dan domestic yang akan berkunjung ke Bali dan kedaerah-daerah Indonesia lainyya serta perekonomian nasional yang mengalami penurunan secara drastic.

Di samping pengertian kejahatan sebagaimana diuraikan di atas, dalam kriminologi dikenal pula apa yang disebut dengan kejahatan tanpa korban (victimless crime). Menurut Black, victimless crime adalah " A crime is considered to have no direct victim, because only consenting adults are involded Examples are possession of drugs, deviant sexual intercourse between conseting adults, and prostitution."

Victimless crime tidak menimbulkan keluhan di masyarakat kecuali pihak penegah hukum seperti polisi, sebagaimana dikatakan Frase: "The practical arguments against Victimless crime appear to derive from three attributes of these offenses: 
a. Most involve no complaining parties other than police officers (Artinya) Kebanyakan tidak melibatkan pihak mengeluh selain polisi.

b. Many involve the exchange of prohibited goods or services that are strongly desired by the participants (Artinya) Banyak melibatkan pertukaran barang atau jasa yang sangat diinginkan dilarang oleh peserta.

c. All sek to prevent individual or social harms that are widely berlieved to be lees erios than the harms involved in crime witch victims (Artinya) Semua sek untuk mencegah bahaya individu atau sosial yang secara luas diyakini kurang serius daripada bahaya yang terlibat dalam korban kejahatan penyihir .

Kejahatan tanpa korban (victimlees crime) biasanya terjadi pada tindak pidana narkotika, perjudian, prostitusi, pornografi, dimana hubungan antara pelaku dan korban tidak kelihatan akibatnya. Tidak ada sasaran korban sebab semua pihak adalah terlibat dalam kejahatan tersebut. Namun demikian, jika dikaji secara mendalam, istilah kejahatan tanpa korban (victimlees crime) ini sebetulnya tidak tepat karena semua perbuatan yang masuk ruang lingkup kejahatan pasti mempunyai korban atau dampak baik secara langsung maupun tidak langsung, atau dalam bahasa agamanya perbuatan-perbuatan yang dilakukan ini lebih banyak mudharatnya dari pada manfaatnya.

\section{Hubungan Korban Kejahatan dan Pelaku Kejahatan}

Korban mempunyai peranan yang fungsional dalam terjadinya suatu kejahatan. Perbuatan pelaku dapat mengakibatkan orang lain menjadi korban, sebagaimana dikemukakan oleh Samuel Walker bahwa hubungan antara korban dan pelaku adala hubungan sebab akibat. Akibat perbuatan pelaku, yaitu suatu kejahatan dan korban yang menjadi objek sasaran perbuatan pelaku menyebabkan korban harus menderita karena kejahatan.

Kerugian yang dialami oleh korban terjadinya suatu kejahatan tidak selalu berupa kerugian materiil, atau penderita fisik saja, tetapi yang paling besar pengaruhnya adalah kerugian atau dampak psikologis. Korban kejahatan bias terus 
merasa dibayang-bayangi oleh kejahatan yang telah meinmpanya yang dapat menghalanginya untuk beraktivitas dalam kehidupannya sehari-hari.

Secara sosiologis dapat dikatakan bahwa dalam kehidupan masyarakat, semua warga Negara berpartisipasi penuh atas terjadinya kejahatan sebab masyarakat dipandang sebagai sebuah system kepercayaan yang melembaga (system of institutionalized trust). Tanpa kepercayaan ini, kehidupan sosial tidak mungkin berjalan dengan baik sebab tidak ada patokan yang pasti dalam bertingkah laku. Kepercayaan terpadu melalui norma-norma yang dieksperesikan di dalam struktur organisasional.

Bagi korban kejahatan, dengan terjadinya kejahatan yang menimpa dirinya tentu akan menghancurkan system kepercayaan tersebut. Dengan kata lain, dapat merupakan suatu bentuk trauma kehilangan kepercayaan terhadap masyarakat dan ketertiban umum, yang berwujud munculnya gejala-gejala rasa takut, gelisah, rasa curiga, sinisme, depresi, kesepian, dan berbagai perilaku penghindaran yang lain, contoh wanita korban kekerasan dalam rumah tangga, khususnya yang mengalami kekerasan dalam hubungan intim. Rasa takut adalah perasaan yang paling mendominasi korban. Rasa takut tersebut mengendalikan perilakunya, dan mewarnai segala tindak-tindaknya. Bahkan ketakutan doa menganggu pola tidurnya, memulculkan insomnia dan mimpi-mimpi buruk. Gangguan tidur dapat memunculkan ketergantungan kepada obat-obat tidur dan obat penenang. Pasangannya dapat mengancam keselamatan dirinya. Bahkan, akan mengancam jiwanya, kalau sampai ia berusaha membuka mulut, atau bila ia berusaha meninggalkan lelaki itu.

Kadang kala, hubungan antara korban dan pelaku kejahatan sering kalu bersifat personal. Hal ini dapat ditemui dalam berbagai jenis kejahatan yang melibatkan keluarga atau yang terjadinya dalam rumah tangga. Pada jenis kejahatan semacam ini, seringnya terjadi kontrak dengan pelaku akan semakin menambah ketakutan dari si korban untuk mengambil tindakan. Apabila korban menangambil tindakan dengan cara melaporkan kepada pihak lain tentunya akan 
mengundang kemarahan tidak hanya kemarahan si pelaku, tetapi juga dari pihak lainnya. $^{32}$

Oleh karena itulah, perlindungan terhadap korban sangat diperlukan, tidak hanya dari si pelaku itu sendiri, melainkan juga dari pihak-pihak yang cenderung tidak menyukai korban maupun perbuatan si korban dengan melaporkan si pelaku.

Menurut E.Kristi Poerwandari, dalam kekerasan terhadap perempuan hubungan antara pelaku dengan korban sangat beragam pelaku, dapat berupa:

a. Orang asing/tidak saling kenal; suami;pasangan hubungan intim lain (pacar,tunangan,bekas suami, dan lain-lainnya); kenalan/teman;anggota keluarga inti dan/atau luas;teman kerja;

b. Orang dengan posisi otoritas;atasan kerja/majikan;guru/dosen/pengajar ; pemberi jasa tertentu (konselur,dokter,pekerja social, dan lain-lain)

c. Negara dan/atau wakilnya;polisi/anggota militer;dan pejabat (individu dalam kedudukan sebagai pejabat).

Untuk kejahatan-kejahatan di luar kekerasa dalam rumah tangga hubungan pelaku dengan korban sangat beragam, tetapi pada umumnya antara pelaku dan korban tidak memiliki relasi secara langsung atau tidak saling mengenal.

\section{Manfaat Viktimologi}

Manfaat yang diperoleh dengan mempelajari ilmu pengetahuan merupakan factor yang paling penting dalam kerangka pengembangan ilmu itu sendiri. Dengan demikian, apabila suatu ilmu pengetahuan dalam pengembangannya tidak memberikan manfaat, baik yang sifatnya praktis maupun terotis, sia-sialah ilmu pengetahuan itu untuk dipelajari dan dikembangkan. Hal yang sama akan dirasakan pula pada saat mempelajari viktimologi. Dengan dipelajarinya viktimologi, diharapkan akan banyak manfaat yang diperoleh.

Arif Gosita menguraikan beberapa manfaat yang diperoleh dengan mempelajari viktimologi, yaitu sbb;

1. Viktimologi mempelajari hakikat siapa itu korban dan yang menimbulkan korban, apa artinya viktimisasi bagi mereka yang terlibat dalam proses

\footnotetext{
32 Ibid.
} 
viktimisasi. Akibat pemahaman itu, akan diciptakan pengertianpengertian, etimologikriminal, dan konsepsi-konsepsi mengenai usahausaha yang preventif,represif, dan tindak lanjut dalam menghadapi dan menanggulangi permasalahan viktimisasi criminal diberbagai bidang kehidupan dan penghidupan.

2. Viktimologi memberikan sumbangan dalam mengerti lebih baik tentang korban akibat tindakan manusia yang menimbulkan penderitaan mental,fisik, dan social. Tujuannya tindakan untuk menyanjung (eulogize) korban, tetapi hanya untuk memberikan beberapa penjelasan mengenai kedudukan dan peran korban serta hubungannya dengan pihak pelaku serta pihak lain. Kejelasan ini sangat penting dalam upaya pencegahan terhadap berbagai macam viktimisasi demi menegakkan keadilan dan meningkatkan kesejahteraan mereka yang melihatlangsung maupun tidak langsung dalam eksitensi suatu viktimisasi.

3. Viktimoogi memberikan keyakinan bahwa setiap individu mempunyai hak dan kewajiban untuk mengetahui mengenal bahaya yang dihadapinya berkaitan dengan kehidupan dan pekerjaan mereka. Terutama dalam bidang penyuluhan dan pembinaan untuk tidak menjadi korban structural atau non structural. Tujuannya adalah bukan untuk menakuti-nakuti, tetapi untuk memberikan pengertian yang baik dan agar waspada. Mengusahakan keamanan atau hidup aman seseorang meliputi pengetahuan yang seluas-luasnya mengenai bagaimana menghadapi bahaya dan juga bagaimana menghindarinya.

4. Viktimologi juga memerhatikan permasalahan viktimologi yang tidak langsung, misalnya efek politik pada penduduk "dunia ketiga" akibat penyuapan oleh suatu korporasi internasional, akibat-akibat social pada setiap orang akibat polusi industry, terjadinya viktimisasi ekonomi, politik dan social setiap kali seorang pejabat menyalahgunakan jabatan dalam pemerintahan untuk keuntungan sendiri. Dengan demikian dimungkinkan menentukan asal mula viktimisasi, mencari sarana menghadapi suatu kasus, mengetahui terlebih dahulu kasus-kasus (antisipasi), mengatasi 
akibat-akibat merusak, dan mencegah pelanggaran kejahatan lebih lanjut (diagnosis viktimologi);

5. Viktimologi memberikan dasar pemikiran untuk masalah penyelesaian viktimisasi kriminal, pendapat-pendapat viktimologi dipergunakan dalam keputusan-keputusan peradukan criminal dan reaksi pengadilan terhadap pelaku kriminal. Mempelajari korban dalam proses peradilan kriminal, merupakan juga studi mengenai hak dan kewajiban asasi manusia.

Manfaat viktimologi pada dasarnya berkenaan dengan tiga hal utama dalam mempelajari manfaat studi korban, yaitu:

1. Manfaat yang berkenaan dengan usaha membela hak-hak korban dan perlindungan hukum;

2. Manfaat yang berkenaan dengan penjelasan peran korban dalam suatu tindak pidana;

3. Manfaat yang berkenaan dengan usah apencegahan terjadinya korban.

Manfaat viktimologi ini dapat memahami kedudukan korban sebagai sebab dasar terjadinya kriminalitas dan mencari kebenaran. Dalam usaha mencari kebenaran dalam usaha mengerti akan permasalahan kejahatan, dilekuensi dan deviasi sebagai satu proporsi yang sebenarnya secara dimensional.

Viktimologi juga berperan dalam hal penghormatan hak-hak asasi korban sebagai manusia, anggota masyarakat, dan sebagai warga Negara yang mempunyai hak dan kewajiban asasi yang sama dengan seimbang kedudukannya dalam hukum dan pemerintahan.

Viktimologi bermanfaat bagi kinerja aparatur penegak hukum, seperti aparat kepolisian, kejaksaan, dan kehakiman. Bagi aparta kepolisian, viktimologi sangat membantu dalam upaya penanggulangan kejahatan. Melalui viktimologi akan mudah diketahui latar belakang yang mendorong terjadinya kejahatan, seberapa besar peranan korban pada terjadinya kejahatan, bagaimana modus operandi yang biasanya dilakukannya oleh pelaku dalam menjalankan aksinya, serta aspek-aspek lainnya yang terkait.

Bagi kejaksaan, khususnya dalam proses penuntutan perkara pidana di pengadilan, viktimologi dapat dipergunakan sebagai bahan perimbangan dalam 
menentukan berat ringannya tuntutan yang akan diajukan kepada terdakwa mengingat dalam praktiknya sering dijumpai korban kejahatan turtu menjadi pemicu terjadinya kejahatan.

Bagi kehakiman, dalam hal ini hakim sebagai organ pengadilan yang dianggap memahami hukum yang menjalankan tugas luhurnya, yaitu menegakkan hukum dan keadilan berdasarkan pancasila demi terselenggaranya Negara Hukum Republik Indonesia, demham adanya viktimologi, hakim tidak hanya menempatkan korban sebagai saksi dalam persidangan suatu perkara pidana, tetapi jiga turu memahami kepentingan dan penderitaan korban akibat dari sebuah kejahatan atau tindak pidana sehingga apa yang menjadi harapan dari korban terhadap pidana sedikit banyak dapat terkonkretisasi dalam putusan hakim. Hakim dapat mempertimbangkan berat ringan hukuman yang akan dijatuhkan pada terdakwa dengan melihat pada seberapa besar penderitaan yang dialami oleh korban pada terjadinya kejahatan, misalnya hakim akan mempertimbangkan hukuman yang akan dijatuhkan pada terdakwa dengan melihat pada seberapa besar penderitaan yang dialami oleh korban pada terjadinya kejahatan, misalnya hakim akan mempertimbangkan hukuman yang akan dijatuhkan pada terdakwa dengan melihat pada penderitan yang dialami oleh korban akibat perbuatan terdakwa. Misalnya korban menderita cacat seumur hidup, korban kehilangan penghasilan, korban kehilangan orang yang salama ini menjadi tumpuan ekonomi keluarga. Seperti dikemukakan oleh Soerjono Koesoemo bahwa hakim yang besar adalah yang putusannya merupakan ilmu hukum, serta dapat dipahami dan diterima para pencari keadilan pada khususnya dan masyarakat pada umumnya.

Akhirnya, viktimologi dapat dipergunakan sebagai pedoman dalam upaya memperbaiki berbagai kebijakan/perundang-undangan yang selama ini terkesan kurang memerhatikan aspek perlindungan korban.

\section{Viktimologi dan Kriminologi}

Secara etimologi, kriminologi berasal dari kata Crime yang berarti kejahatan dan Logos yang berarti pengetahuan atau ilmu pengetahuan. Kriminologi diartikan sebagai ilmu yang membahas mengenai kejahatan. 
Jika diperhatikan secara lebih luas, dapat kita ambil contoh pengertian kriminologi yang dikemukakan oleh Sutherland dan Cressey yang menyebutkan bahwa kriminologi adalah "the body of knowledge regarding crime as a social phonemenon". Termasuk dalam pengertian kriminologi tersebut adalah proses perbuatan undang-undang, pelanggaran hukum, dan reaksi pelanggaran hukum tersebut.

Secara umum, kriminologi bertujuan untuk mempelajari kejahatan dari berbagai aspek sehingga diharapkan dapat memperoleh pemahaman tentang fenomena kejahatan yang lebih baik.

Menurut antropolog Prancis P.Topinard (18389-1911), kriminolog merupakan ilmu pengetahuan yag bertujuan menyelidiki gejalah kejahatan seluasluasnya (kriminolog teoritis/murni). Kriminolog teoritis adalah ilmu pengetahuan yang berdasarkan pengalam seperti ilmu pengetahuan lainnya yang sejenis, memerhatikan gejala-gejala dan mencoba menyelidiki sebab-sebab dari gejalagejala tersebut (aetiologi) dengan cara-cara yang ada padanya.

Jadi pada pokoknya, kriminologi merupakan ilmu yang menyelidiki kejahatan, serta aspek-aspek yang menyertai kejahatan tersebut, yakni selain mengenai pokok-pokok kejahatan yang dilakukan, juga orang-orang yang melakukan kejahatan tersebut. Akan tetapi, kriminologi tidak menyelidiki kejahatan dari segi yurudisnya ataupun perumusan jenis-jenis kejahatan tersebut. Bahasan yang terakhir disebutkan merupakan bahasan dari bidang hukum pidana.

Kriminologi merupakan salah satu ilmu pengetahuan yang usianya relative muda. Kriminologi baru muncul pada abad ke-19, bersamaan dengan lahirnya sosiologi. Hal ini disebabkan karena perhatian khusus mengenai kejahatan hanyalah disinggung sepintas lalu dalam buku-buku karangan para sarjana terdahulu, seperti pada buku karangan Van Kan "Les Causes Economiques de la Criminalitel" (1903), yang mengemukakan pendapatnya tentang sebab-musabab ekonomis kejahatan. Kemungkinan Havelock Ellis dalam bukunya The Criminal (1889), Maro dalam bukunya I Caratteri dei Delinquenti (1887), dan G. Antonini dalam bukunya I Precuri di Lombroso (1909) yang mencari pendapat tentang kejahatan menurut antropologi, tetapi hasilnya sangat kecil. Begitu pula halnya 
dengn hasil karya Plato dan Aristoteles yang membahas mengenai kejahatan dalam hubungannya dengan kehidupan suatu Negara.

Lahirnya kriminologi ditandai dengan munculnya gerak-gerakan menentang pemerintah yang dianggap sewenang-enang dalam menerapkan hukum pidana serta hukum acara pidananya, diamana pada waktu itu hukum pidaa diterapkan dengan tujuan untuk menakuti-nakuti masyarakatnya dengan menerapkan hukuman penganiayaan yang mengerikan.

Proses pemeriksaan orang yang disangka melakukan kejahatan pun sama tidak berprikemanusian. Pemeriksaan hanya bersifat formalitas saja. Dimana dalam suatu pemeriksaan dalamaturan hukum adalah harus dalam keadaan yang dirahasiakan, tempatnya harus kadaan yang nyaman tidak ada hilir mudi, barangbarang yang membahayakan harus diamankan karena menjaga hal-hal yang tidak diinginkan untuk terjadinya suatu tindak pidana. Ketika, itu pengakuan dari si tertuduh dipandang sebagai syarat pembuktian yang utama.

Gerakan penentangan semacam ini muncul menjelang revolusi Prancis yang pada saat itu kekuasaan raja sangat absolute. Pada masa itu, orang-orang yang ditengarani melakukan penentangan terhadap kekuasaan raja langsung dijebloskan ke dalam penjara Bastille. Penentangan-penentangan semacam ini dikeluarkan oleh tokoh-tokoh Prancis seperti Montesquience, Rosseau dan Voltaire. Ketiganya menyatakan penentangan kepada tindakan sewenang-wenang, hukuman yang kejam serta banyaknya hukuman yang dijatuhkan.

Selain ketiga tokoh tersebut, mulai bermunculan pula perkiraan-perkiraan tokoh yan menyuarakan penentangan terhadap hukuman yang berlaku pada saat iu, yang berlaku kejam terhadap penjahat. Pada tahun 1777 oleh "Oeconomiche Gesell Schaft" di Bernd diadakan sayembara untuk merencanakan suatu hukum pidana yang baik.

Hasil perjuangan para tokoh tersebut kemudian melahirkan hasil yang baik. Pada tahun 1780 di Prancis penganiayaan dihapuskan. Setelah sebelumnya pada tahun 1740. Frederik Agung sudah menghapuskan lebih dahulu. Namun, jasa yang sangat besar dari JohnHoward (1726-1790) dalam bukunya The State Of The Prisons (1777), terutama mengenai rumah penjara di Inggris dan dalam cetakan 
yang belakang mengenai kepenjaraan di Negara lain. Menunjukan keadaan yang menyedihkan baik dari segi kesehatan maupun kesusilaan.

Sekitar tahun 1880 di Amerika karena pengaruh golongan Quaker, didirikan berkumpulan-berkumpulan yang memerhatikan masalah kebenaran dengan tujuan memberantas akibat-akibat yang sangat mendesak yang timbul dari adanya penutupan bersama dalam rumah penjara. Penutupan tersendiri yang akan memberikan kesempatan pada kejahatan untuk memeriksa diri sendiri (dan karenanya menyesal, akan mengantikan penutupan bersama. Pada tahun 1786 hukuman mati di Pennsylvania dihapuskan.

Setelah berakhirnya masa penentangan terhadap hukum pidana dan juga hukum dan juga hukum acara pidana, barulah focus terhadap kejahatan serta pelakunya diterealisasinya.

Dalam ilmu kriminologi modern dikenal 3 ahli pemikiran untuk menjelaskan gejala kejahatan, yaitu sebagai berikut:

1. Kriminologi Klasik

Dalam hal ini, gambaran tentang kejahatan dan penjahat pada umumnya dipandang dari sudut hukum, kejahatan diartikan sebagai perbuatan yang dilarang oleh Undang-undang Pidana dan penjahat adalah orang yang melakukan kejahatan. Orang melakukan kejahatan sebagai pilihan bebas masing-masing individu dengan menilai untung ruginya.

\section{Kriminologi Positif}

Aliran pemikiran ini bertolak dari pandangan bahwa perilaku manusi ditentukan oleh factor-faktor di luar kontrolnya, baik berupa factor biologis maupun cultural. Dengan demikian, manusia tidak bebas untuk menentukan perbuatanyya karena dibatasi dan ditentukan oleh situasi biologis atau kulturalnya.

\section{Kriminologi Kritis}

Aliran pemikiran ini mulai berkembang setelah tahun 1960-an sebagai pengaruh dari semakun populernya perspektif labeling. Aliran ini tidak mempersoalkan apakah perilaku manusia itu bebas atau dipengaruhi pada proses-proses yang terjadi. Dengan demiian, aliran ini mempelajari proses- 
proses dan kondisi yag memengaruhi pemberian batasan atau mendefinisikan kejahatan pada perbuatan-perbuatan tertentu, orang-orang tertentu, pada waktu dan tempat tertentu.

Jika telah lebih dalam, tidak berlebihan apabila dikatakan bahwa viktimologi merupakan bagian yang hilang dari kriminologi atau dengan kalimat lain, viktimologi akan membahas bagian-bagian yang tidak mencakup dalam kajian kriminologi.

Akan tetapi, mengenai pentingnya dibentuk ilmu Viktimologi secara terpisah dari ilmu kriminologi mengundang beberapa pendapat, yaitu sebagai berikut:

4. Mereka yang berpendapat bahwa viktimologi tidak terpisahkan dari kriminologi, diantaranya adalah Von Hentig, H. Mannheim dan Paul Cornil. Mereka mengatakan bahwa kriminologi merupakan ilmu pengetahuan yang menganalisis tentang kejahatan dengan segala aspeknya, termasuk korban.

5. Mereka yang mengiginkan viktimologiterpisah dari kriminologi, di antaranya adalah Mendelsohn. Ia mengatakan bahwa viktimologi merupakan suatu cabang ilmu yang mempunyai teori dalam kriminologi, tetapi dalam membahas persoalan korban, viktimologi juga tidak dapat hanya terfokus pada korban itu sendiri.

Khusus mengenai hubungan antara kriminologi dan hukum pidana dikatakan bahwa keduanya merupakan pasangan atau dwi tunggal yang saling melengkapi karena orang akan mengerti dengan baik tentang penggunaan hukum terhadap penjahat maupun mengenai timbulnya kejahatan dan cara-cara pemberantasannya sehingga memudahkan penentuan adanya kejahatan bagaimana menghadapinya untuk kebaikan masyarakat dan pelaku kejahatan.

Menurut pendekatan kriminologi, ada beberapa alasan perlunya korban kejahatan mendapatkan perhatian, yaitu sebagai berikut :

1. Sistem peradilan pidana dianggap terlali banyak memberikan perhatian kepada permasahalan dan peranan pelaku kejahatan (offender-centeredl). Bukti konkret pandangan ini adaldah hanya beberapa pasal di dalam 
KUHAP yang mencerminkan perlindungan terhadap korban. Pasal-pasal tersebut, antara lain sebagai berikut :

a. Pasal 80 KUHAP

Permintaan untuk memeriksa sah atau tidaknya suatu penghentian penyidikan atau penuntutan dapat diajukan oleh penyidik atau Jaksa Penuntut Umum, atau pihak ketiga yang berkepentingan kepada Ketua Pengadilan Negeri dengan menyebut alasannya. ${ }^{33}$

b. Pasal 108 ayat (1)

Setiap orang yang mengalami, melihat menyaksikan dan atau menjadi korban peristiwa yang merupakan tindak pidana berhak untuk mengajukan laporan atau pengaduan kepada penyidik atau penyelidik, bak lisan maupun lisan.

c. Pasal 133 ayat (1)

Dalah hal penyidik untuk kepentingan peradilan menangani korban baik luka, keracunan, ataupun mati yang diduga karena peristiwa yang merupakan tindak pidana, ia berwenang mengajukan permitaan keterangan ahli kepada ahli kedokteran kehakiman atau dokter atau ahli lainnya.

d. Pasal 134 ayat (1)

Dalam hal sangat diperlukan dimana ntuk keperluan bedah mayat tidak mungkin lagi dihindari, penyidik wajib memberitahukan terlebih dahulu kepada keluarga korban.

e. Pasal 169 ayat (1b)

Yang pertama-tama didengar keterangan adalah korban yang menjadi sanksi

1. Terdapat potensi informasi dari korban kejahatan untuk memperjelas dan melengkapi penafsiran atau stastik kriminal (terutama stastik yang terdapat pada kepolisian yang dilakukan memalui survei tentang korban kejahatan).

2. Masyarakat yang berkembang akan semakin menyadari bahwa di saming korban kejahatan konvensional (kejahatan jalanan/steet crime) tidak

\footnotetext{
${ }_{33}$ A. Hamzah, Irdan Dahlan. Perbandingan KUHAP HIR dan Komentarnya. Ghazali Indonesia, Jakarta. 1984. HIm. 120.
} 
kurang pentingnya untuk memberikan perhatian kepada korban kejahatan non konvensional maupun korban dari penyalahgunaan kekuasaan.

Dewasa ini, terdapat kecenderungan bahwa masalah korban dibahas secara tersendiri dan terperinci dalam ilmu viktimologi dan bukan merupakan cabang ilu kriminologi, padahal antara viktimologi dan kriminologi, akan selalu terdapat hubungan yang berkesinambungan dan saling memengaruhi.

Menurut Von Hentig,H. Mannheim dan Paul Cornil kriminologi merupakan ilmu pengetahuan yang menganalisis tentang kejahatan dengan segala aspeknya, termasuk korban. Selain itu, viktimologi tidak hanya terfokus kepada korban itu sendiri, tetapi juga melihat kedudukan kejahatan sebagai penyebab timbulnya korban, dan kejahatan hanya ada dalam kaitan kriminologi.

\section{Viktimologi dan Ilmu Hukum}

Secara terminologi menurut Hugo Reading, viktimologi adalah ilmu hukum yang mempelajari tentang korban, penyebab timbulnya korban dan akibat-akibat penimbulan korban yang merupakan masalah manusia sebagai suatu kenyataan sosial.

Ilmu hukum adalah ilmu tentang hukum yang berlaku di suatu Negara atau masyarakat tertentu, dan hukuman dalam hal ini adalah hukum positif (ius contitutum). Hukum yang menjadikan dari ilmu hukum adalah hukum yang bertalian dengan kehidupan manusia dalam masyarkat. Kehidupan masyarakat dalam hal ini adalah proses sosial, tempat terjadinya pengaruh timbal balik antara berbagai segi kehidupan (politik,ekonomi,agama,dan sebagainya) sebagai sebuah interaksi yang dapat berlangsung dalam bentuk komunikasi, konflik, kompetisi, akomodasi, asimilasi, dan kooperasi. Aspek kehidupan yang digunakan dalam hal hubungan antara ilmu hukum dan viktimologi adalah konflik, dimana terdapat konflik, terjadi pertentangan, dan dalam pertentangan pasti terdapat sebuah viktimisasi criminal, yang berlaku menyeimbangkan dan mempertahankan perdamaian. Sementara itu, bagi viktimologi, dalam masyarkat terdapat hal yang dapat menyebabkan timbulnya korban serta akibat-akibat korban yang merupakan kenyataan sosial. 


\section{$B A B$ III \\ Judgment without Justice (Penghukuman Tanpa Hakim)}

Penghukuman atau lebih tepatnya Penghukuman Tanpa Hakim (Judgment Without Justice) ini adalah merupakan tindakan sewenang-wenang oleh pelaku kejahatan tanpa memperhitungkan segala resiko atau hak-hak hukum dari korban itu sendiri. Oleh karena itu kebijakan dalam suatu aturan hukum harus mempunyai warna yang jelas, karena dengan tidak adanya kepaercayaan terhadap para penegak hukum akibatnya para pencari keadilan memberikan warna hukum tersendiri.

Dalam masa reformasi pencari keadilan selalu bentrok dengan para penegak hukum, bentrokan tersebut dipicu oleh karena para penegak hukum dalam melakukan penyelidikan maupun penyidikan indikasinya selalu mempertahankan oknum-oknum mempunyai materi yang memadai atau yang mampu, sedangkan si pencari keadilan mengharapkan kebenaran dan kepastian hukum serta keadilan sebagaimana diamanatkan dalam Undang- Undang Dasar Negara Republik Indonesia Tahun 1945 Pasal 27 ayat (2). Hilangnnya kepercyaan (sudah tidak ada lagi) dimata masyarakat, karena menurut penulis keadilan bagi korban hanya bemper untuk landasan hukum bagi sang penguasa. Ini adalah bertul-betul tugas yang sangat amat berat bagi pemerintah bersama-sama utusan rakyat (DPR) harus memberikan suatu kepastian hukum dan keadilan pada saat penyusunan undangundang baik itu Kitab Undang-Undang Hukum Pidana maupun Kitab UndangUndang Hukum Acara Pidana.

Pelemik dalam suatu putusan berdampak pada suatu reaksi yang mewarnai tubuh sang ilmuan menjadi bermacam ragam penafsiran, akibatnya seseorang menjadi tersangka atau terpidana akibat gonjang-ganjing putusan yang tidak mempunyai kepastian hukum. Alangka naifnya bila itu terjadi pada diri kita, oleh karena itu sebelum memutuskan ingat kibatnya (ilmu Viktimologi), jangan karena kelalaian, kurangnya pemahaman hukum, kurangnya ketelitian, kurangnya pengawasan, seseorang akan menjadi korban, yang menjadi korban bukan hanya diri pribadi seseorang tersebut akan tetapi seluruh yang terkait atau yang 
mempunyai hubungan, baik itu ada hubungan tali darah, hubungan perkawianan, ataupun apa namanya akan tetapi bila itu ada kedekatan secara emosinal dia juga menjadi korban. Korban itu ada dua macam, ada korban secara langsung maupun tidak secara langsung. ${ }^{34}$

Korban secara langsung adalah korban yang langsung dialami oleh korban tersebut dalam suatu peristiwa pidana atau akibat dari suatu kejahatan. Sedangkan korban tidak secara langsung adalah akibat dari perbuatan seseorang yang mana hal tersebut tanpa sepengetahuan dari orang yang turut menjadi korban tersebut akan tetapi akibat adanya hubungan atau kedekatan maka iapun turut menjadi korban.

Terjadinya suatu peristiwa pidana bukan karena kehendak seseorang untuk melakukan peristiwa tersebut, akan tetapi adanya kesemptan dari korban itu sendiri yang membuat terjadinya peristiwa pidana. Korban terkadang tidak mengetahui bahwa yang dilakukan itu akan menimbulkan peristiwa pidana, yang mengorbankan dirinya tanpa ia sadari, akan tetapi perbuatan yang menimpa dirinya tersebut adalah akibat tidak adanya penegtahuan hukum, kurangnya sosialisasi dari aparat penegak hukum kepada masyarakat, maka yang menjadi korban ia sendiri (masyarakat). Disinilah peran serta pemerintah, untuk melihat fakta-fakta yang menjadi pelemik dalam suatu peristiwa pidana, dimana hal tersebut terjadi akibat kurangnya perhatian yang diberikan oleh para penegak hukum maka dampak yang timbul adalah menghakimi seseorang tanpa memandang segala akibatnya, namun mereka sipembuat kejahatan yang diinginkan adalah kepuasan batin, kenapa penulis menyampaikan demikian karena para penegak hukum sudah tidak lagi dipercayai untuk tempat para pelaku atau korban untuk berlindung. Pertanyaanya kemana lagi mereka harus mengadu. Intinya adalah lakukan perbaikan dalam struktur organisasi, berikan pelayanan yang baik, posisikan mereka sebagai yang membutukan keadilan, kepastian hukum serta pemenuhan pemahaman yang baik dalam bidang hukum.

Dengan hal-hal tersebut diatas, apabila segala sesuatu mempunyai kepastian hukum penulis memberikan harapan yang positif akan pulihnya kepercayaan masyarakat dengan adanaya penegakan hukum baik itu dari aparat Kopolisia,

\footnotetext{
${ }^{34}$ Julaiddin, Op Cit., hlm.77
} 
Kejaksaan, Hakim, Advokat. Salah satu contoh penulis dalam buku ini mengungkapakan kasus polemik dalam Pasal 197 ayat (1) huruf k KUHAP, yang mana hal tersebut perdebatan para pemikir bangsa membuat hancurnya kepercayaan, kenapa demikian penulis ungkapkan karena akibat kelalaian dalam suatu penulisan ataupun kurangnya kecerdasan dalam membuat suatu putusan maka bisa berakibat fatal bagi seseorang yang mencari keadilan ataupun kepastian hukum yang sebenar-benarnya yang diciptakan dari hati nurani seseorang yang telah di berikan kekuasaan oleh Undang-undang dalam membuat suatu penyelidikan, penuntutan maupun suatu putusan yang menyangkut nasib seseorang, oleh karena itu pertimbangkan, pahami, selidiki, pelajari, pikirkan, telaa dengan baik, kemudian lakukan tindakan sesuai dengan aturan dalam porsi masing-masing. Jangan memancing dikolam orang lain karena itu disebut dengan mencuri, akan tetapi juga jangan ikut orang yang memancing ditengah laut pada saat badai atau ombak sedang mengamuk karena bisa-bisa anda menajadi korban perbuatan sendiri. Secara filosofis, itu dilakukan akan tetapi lihat-lihat dulu agar jangan terseret ombak, karena anda tidak dapat berenang untuk menyelamatkan diri ketepian. Pastikan anda bisa berenang baru lakukan. ${ }^{35}$

Judgment Without Justice are an arbitrary actions by the perpetrators regardless of any risk or legal rights of the victims themselves. Therefore the policy in a rule of law must have a clear color, due to the absence of law enforcement kepaercayaan against those seeking justice consequently give the color its own law. In seeking justice reform period has always clashed with the law enforcers, the clashes triggered by law enforcement officials always retain elements have sufficient material while expecting justice seeker of truth and justice and the rule of law as mandated in the Constitution of the Republic of Indonesia 1945 Article 27 paragraph (2). Lost of kepercyaan (no longer exists) in the eyes of the public, because according to the writer just for justice for victims of the bumper to the legal basis for the ruling. This is true bertul-together government representatives of the people (Parliament) must provide legal certainty and fairness when drafting laws be it the draft Penal Code and Code of Criminal Procedure.

Pelemik in a decision that affects a reaction to the body color scientist into a profusion of interpretation, as a result a person becomes a suspect or convict broke down due to decisions that do not have legal certainty. Alangka naive when it happens to us, therefore before deciding remember kibatnya (science of victimology), not because of negligence, lack of understanding of the law, lack of rigor, lack of supervision, a person will be a victim, a victim who is not only one's

\footnotetext{
35 Ibid hlm. 89
} 
personal self will But all who are related or who have a relationship, whether it's cord blood relationship, relationship perkawianan, or what it's called but if there are emotional closeness she was also a victim. Korba that there are two kinds, no victim directly or indirectly.

Direct victims are victims who directly experienced by the victim in a criminal event or a result of a crime. While the victim was not directly the result of one's actions and that it is without the knowledge of the people who have contributed to the victim but due to so she began a relationship or closeness among the victims. Occurrence of an event because of the will of a person's criminal not to do the event, but the kesemptan of the victims themselves who make criminal incident. Victims sometimes do not know that it would lead to criminal events, who sacrificed himself without realizing it, but the deeds that befell him penegtahuan is due to the absence of law, lack of socialization of law enforcement officers to the community, then that becomes the victim of his own (society). This is where the role of government, to look at the facts that became pelemik in a criminal incident, in which it occurs due to the lack of attention given by the law enforcement then the effects are judging someone without regard to the consequences, but they desired sipembuat crime is inner satisfaction, why did the author convey so because law enforcement is no longer believed to place the perpetrators or victims for shelter. The question is where else they should complain. The point is to do improvements in organizational structure, provide good service, their position as requiring a justice, rule of law and compliance with good understanding in the field of law. With the things mentioned above, if everything has a legal certainty that the author gives a positive expectation on the recovery of public confidence in law enforcement adanaya either from Kopolisia apparatus, Attorney, Judge, Advocate. One example the authors in this book mengungkapakan case polemic in Article 197 paragraph (1) letter $k$ Criminal Procedure Code, and that it is the nation's debate thinkers make the destruction of trust, why not reveal the author as a result of negligence in writing or a lack of intelligence in making a decision then it could be fatal for someone who is looking for justice or the rule of law in truth that was created from the conscience of someone who has been given power by an Act in making an investigation, prosecution or a decision concerning the fate of a person, therefore consider, understand, explore, learn, think, telaa well, then take action in accordance with the rules in each serving. Do fishing pond others because it is called stealing, but also do not follaw people fishing on the high seas in a storm or the waves are raging because you might menajadi victim of its own. Philosophically, it is done but look around the waves swept him not, because you can not swim to save themselves ketepian. Make sure you can do a new swim. 


\section{A. Pengusutan Perkara Kriminal Melalui Sarana Teknik dan Sarana Hukum (Untuk Mencapai Keadilan dan Kepastian Hukum)}

Hal yang penting dalam penulisan buku Penghukuman Tanpa Hakin ini adalah sesuatu untuk ditelusuri atau diteliti kembali sebelum sang mangsa melakukan tindakan sewenag-wenang adalah Sebelum lahirnya Undang-Undang Pokok Kepolisian dan Kejaksaan pada tahun 1961 (Undang-Undang Nomor 13 Tahun 1961 dan Undang- Undang Nomor 15 Tahun 1961), umum dipakai istilah" Pengusutan" sebagai pedoman istilah Belanda opsporing dan istilah Inggris investigation. Tetapi dengan diperkenalkanyya istilah baru oleh kedua undangundang tersebut, yaitu "penyidikan" dalam arti yang sama dengan yang tersebut di atas, maka sejak itu hilanglah secara perlahan-lahan istiah "pengusutan" tersebut yang biasanya dipakai oleh para penerjemah HIR menjadi RIB untuk menjalin istilah Belanda dalam HIR, yaitu opsporing tersebut. ${ }^{36}$

Pertama-tama perlu diperhatikan tentang pengertian opsporing tersebut yang dahuu diterjemahkan dengan "pengusutan" dan kemudian diubah oleg pembuat undang-undang menjadi "penyidikan" itu.

Kalau kita menengok kamus hukum misalnya Fockema Andreae, Rechtsgeleerd Handwoordenboek, kita mendapatibahwa yang dimaksud dengan opsporing atau opsporing onderzoek (pemeriksaan penyidikan, pengusutan) ialah pemeriksaan suatu delik oleh polisi dan penuntut umum sebelum pemeriksaan (pendahuluan) di muka siding pengadilan. Fockema Andreae menulis kamus hukum ini untuk Negeri Belanda, di mana ada pemeriksaan pendahulun oleh hakim komisaris (Rechter Commissaris) yang di Indonesia tiadak ada. Jadi kata "pendahuluan" di dalam pengertian belanda itu jika disadur untuk Indonesia, harus ditiadakan, sehingga menjadi “...sebelum pemeriksaan di muka sidang pengadilan."

Secara yuridis teknis, pengertian opsporing (pengusutan/penyidikan) terkenal definisi de Pinto yang terjemahanyya sebagai berikut:

\footnotetext{
${ }^{36}$ Andi Hamzah, Pengusutan Perkara Kriminal Melalui Sarana Teknik dan Sarana Hukum, Ghalia Indonesia, Jakarta Tahun 1984. Hlm. 5
} 
"Pemeriksaan permulaan oleh pejabat-pejaba yang untuk itu ditunjuk oleh undangundan segere telah mereka dengan jalan apa pun mendegar kabar yang sekedar beralasan bahwa terjadi sesuatu pelanggaran hukum" (Tresna, t.t: 72, Bonn Sosrodanukusumo, t.t.. 102. De Pinto: 50).

Van Bemmelen tidak menyetujui pendapat yang demikian, karena menurutnya acara pidana yang dimulai dengan penyidikan itu mungkin terjadi tanpa terjadinya pelanggaran pidana, misalnya kasus Calas di Prancis, dimana seorang ayah telah dipidana karena terdakwa membuhnuh anaknya, padahal tidak terjadi. Ini dapat dibandingkan dengan kasus Sengkon dan Karta di Indonesia jadi, sesuatu penyidikan/pengusutan (opsporing) harus berpangkal tolak pada pencarian kebenaran (Van Bemmelen, 1950:1).

Sekarang, perlu kita tinjau perbedaan istilah pengusutn dan penyidikan. Istila pengusutan berasal dari kata usut, yang kira-kira padanan istilah opsporen dalam bahasa Belanda. Menurut kamus umum Belanda-Indonesia, susunan Wojowasito, opsporen, spoorde op, opgespoord, dengan mencari mencoba menemukan atau menemukan dengan mencari (Wojowasito, 1981: 469).

Sebenarnya menurut pendapat penulis, istilah opsporen itu lebih tepat diterjemahkan dengan mengusut dari pada menyidik karena kata menyidik berasal dari kata sidik yang artinya lebih smpit. Menurut penulis buku Penghakiman Tampa Hakim, meyidik berarti memeriksa, menyelidiki, mengamat-amati. ${ }^{37}$ Sedangkan mengusut berari memeriksa, menyelidiki perkara dan sebagainya yang belum terang dan sebagainya, mencari keterangan tentang sesuatu perkara dan sebagainya.

Seperti kita pelajari, sarana hukum acara pidana itu dibantu oleh ilmu lain seperti kriminoogi, kriminalistik, psikoogi, psikiatri, daktiloskopi, antropologi, kedokteran forensik, kimia forensik, balistik forensik dan lain-lain. Ilmu-ilmu sebagai pembantu tersebut penulis golongkan dalam "sarana teknik."

Kalau hukum acara pidana menjadi bagian bidang sarjana hukum, maka sarana teknik ini menjadi bagian bidang ahli-ahli bersangkutan, seperti kriminog, psikolog, psikiateis, antropolog, dokter dan seterusnya.

\footnotetext{
${ }^{37}$ Ibid hlm. 6.
} 
Jadi, dalam pembagian bidang sarana hukum dan sarana teknik ini terjadi pembagian tugas (diferensiasi dan spesialisasi antara sarjana hukum dan ahli-ahli tersebut). Secara struktural pembagian tersebut dapat dipersempit pula menjadi bidang hukum yang ditangani oleh Jaksa dan bidang fisik (interogasi, daktiloskopi dan lain-lain) ditangani oleh kepolisian.

Pembagian fungsi menurut sarana hukum dan sarana teknik ini merupakan diferensiasi, spesialisasi vertikal. Berlainan dengan ketentuan dalam KUHAP dimana pembagian fungsi antara kepolisian dan kejaksaan secara horizontal. Penyidikan di tangan kepolisian, baik sarana hukum maupun sarana tekniknya sedngkan kejaksaan pada tahap berikutnya, yaitu penuntutan.

Pembagian Fungsi vertikal:

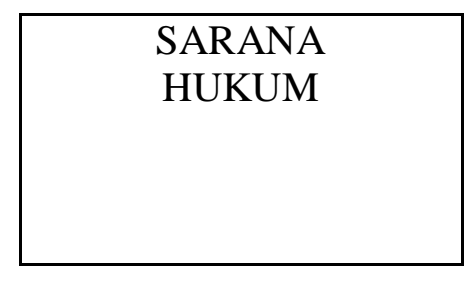

PENGUSUTAN

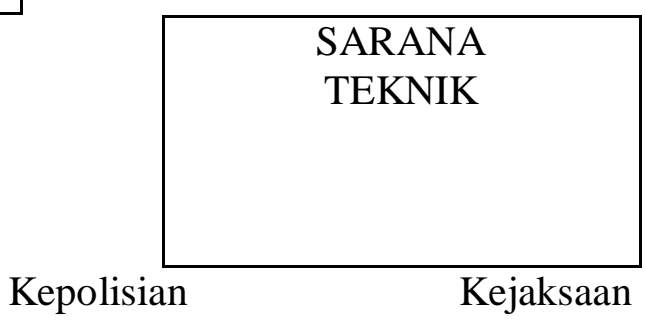

Penyidikan (Pengusutan)
Penuntutan

Pembagian fungsi secara horizontal (KUHAP): Kepolisian Kejaksaan

Kekecualian ialah ketentuan dalam Pasal 284 KUHAP berkaitan dengan Pasal 17 PP Nomor 27 Tahun 1983, yang memungkinkan kejaksaan menyidik 
(mengusut) delik-delik dalam perundang-undangan pidana khusus. ${ }^{38}$ Dengan demikian, menurut pendapat penulis dalam buku yang berjudul Penghakiman tanpa Hakim, terjadi pembagian fungsi vertical dalam pengusutan perkara delik-delik tersebut, yaitu kejaksaan pada bidang sarana hukum, sedangkan douane misalnya pada bidang sarana teknik seperti pengetahuan jenis barang (waren kennis) dalam perkara penyelundupan, atau pejabat tera dalam penentuan teknik ukuran atau perwira angkatan laut dalam penentuan batas garis zone ekonomi eksklusif di laut dan seterusnya.

Kekecualian tersebut apabila hukum berjalan sesuai dengan ketentuan yang dikehendaki oleh para pencari keadilan maka Negara ini akan damai sentosa. Akan tetapi kemungkinan-kemungkina itu secara faktual belum ada dan/atau belum menciptakan kepastian hukum yang adil serta bijaksana sebagaimana ketentuan dalam Kitab Undang-Undang Hukum Pidana dan atau Kitab Umdang-Undang Hukum Acara Pidana yang diharapkan. Akan tetapi, dalam penulisan buku Penghakiman Tanpa Hakin ini akan mencoba membuka hati nurani para penegak hukm agar dalam menjalankan proses hukum agar di upayakan menciptakan suasana rasa adil tanpa melihat atau memandang antara sang pemilik harta yang banyak dan/atau sang miskin yang melarat, dimana sang miskin karena kesalahan yang sebenarnya dapat dimaafkan secara phisikologis, oleh karena tidak mempunyai kemampuan baik secara hukum amaupun secara vinansia (materi) yang diharapkan maka sang miskin tersebut harus menjalani dan/atau harus menduduki kursi pesakitan. Akan tetapi perbuatan itu apabila ada pada pihak mempunyai vinansial yang melebihi ambang batas, maka semuanya dapat terselasaikan dengan tidak lagi memandang norma-norma dalam aturan hukum itu sendiri akan tetapi yang terpenting para pihak mempunyai finansial yang lebih.

Penjahat dan Korban dari suatu kejahatan itu adalah sesuatu yang sangat ditakuti oleh siapa saja, namun bagi penguasa itu adalah hal yang biasa. Banyak kasus-kasus yang melanda negeri ini, dimana mereka tanpa sepengetahuannya apa yang telah dilakukan tiba-tiba bencana tanpa disengaja langsung menerkam mereka, namun belum sempat melakukan pertanyaan atau penyelidikan korban atau

\footnotetext{
38 Ibid Hlm. 7-8.
} 
pelaku telah hilang hak-haknya, apa sebabnya penulis menyatkan demikian" anatar kejahatan biasa dan Kejahatan berdasi "luar biasa"Ordenary Crime Fund extraordinary Crime" itu adalah salah satu kejahatan yang masing masing mempunyai perbedaan yang sangat menyedihkan menurut phisikologis.

\section{B. Hubungan Viktimologi dan Kriminologi tentang adanya Interogasi Terhadap Tersangka Yang Sudah Jelas Kesalahannya}

Taktik-taktik yang dianjurkan sebagai berikut:

1. Tunjukkan sikap yang penuh keyakinan tentang salahnya tersangka.

2. Sebutkan bukti-bukti dan keadaan-keadan yang menunjukan kesalahannya.

3. Tunjukan keadaan-keadaan jasmani dan rohani dimana menunjukan kesalahan tersangka (sementara diperiksa).

4. Cari simpati dari tersangka, dengan mengatakan bahwa siapa pun juga akan melakukan hal yang sama dalam keadaan yang sama.

5. Kurangi rasa bersalah dari tersangka dengan jalan mengecilkan arti jeleknya perbuatan tersangka.

6. Beri sugesti motivasi atau alasan sehingga ia melakukannya yang dapat diterima.

7. Cari simpati dari tersangka dengan jalan mengutuk sikorban, mengutuk kaki tangganya atau siapa saja yang bias dibebani tanggung jawab moral sehingga terjadi perkara itu.

8. Tunjukan simpati dan pengertian dalam mendesak tersangka menceritakan kebenaran.

9. Tunjukan kemungkinan dibesar-besarkannya oleh pelapor tentang kejahatan yang dilakukan tersangka.

10. Buat sedemikian rupa sehingga tersangka menempatkan dirinya dalam lingkaran kejahatan itu atau suatu cara sehingga terjadi konrak antara tersangka dengan korban atau peristiwa itu.

11. Jika ia ternyata berbohong, cari pengakuan bahwa ia bohong mengenai beberapa segi tertentu dari peristiwa. 
12. Angkat-angkat dan puji-puji diri tersangka. ${ }^{39}$

13. Tekankan tentang sia-sianya tersangka mengikari menceritakan kebenaran.

14. Tunjukan kepada tersangka konsekuensi yang besar dan sia-sianya untuk meneruskan sikap-sikap kriminal.

15. Dari pada mencari pengakuan keseluruhan tentang kesalahannya tersangka lebih baik ditanyakan beberapa detail dari kejahatan itu atau keterangan tentang alasan sehingga melakukan delik kerja.

16. Apabila ada dua tersangka yang bekerja sama dalam kejahatan itu, dan ternyata sesudah diinterogasi tidak mempan taktik-taktik tersebut di aras, memainkan yang satu dengan yang lainnya.

Demikianlah taktik-taktik yang dianjurkan oleh Inbau cs yang tentunya disesuaikan dengan system hukum acara pidana Amerika Serikat dn watak bangsa Amerika khususnya penjahatnya. Sebagai diketahuio acara pidana Amerika sangat berbeda dengan acara pidana Indonesia (dan Belanda!). Amerika menganut system juri dan system pemeriksaan pengadilan yang disebut croos examination, yaitu pertanyaan gencar dari jaksa terhadap tertuduh dan saksi-saksi (terutama yang $a$, decharge), dan sebaliknya oleh pembela terhadap saksi-saksi terutama yang $a$, charge yang dimajukan jaksa.

\section{Hubungan Vikrimologi dengan Integrasi Terhadap Tersangka Yang belum Jelas Kesalahannya, Atau Kesalahannya Masih Diragukan.}

Oleh karena disini kita menghadapi tersangka yang belum jelas kesalahannya maka lebih diperlukan banyak psychological approach. Dari sejumlah tersangka yang dicurigai, diteliti secara cermat, dipilih beberapa diantaranya yang lebih mencurigakan, sehingga lingkarannya makin lama makin kecil. Mencari orang yang bersalah di antara beberapa orang dipergunakan taktik interogasi sebagai berikut: ${ }^{40}$

\footnotetext{
${ }^{39}$ Ibid hlm. 63
}

40 Ibid hlm. 81 
1. Pada permulaan interogasi ditanyakan kepada tersangka, apa sebab sehingga dia dipanggil. Dari pertanyaan itu saja sudah bisa memisahkan yang bersalah dan yang tidak. Yang bersalah menjadi peka, sesudah berpikir sebentar dia akan akan cepat menjawab dan membela diri. Sebaliknya yang tidak bersalah akan menjawab tidak tau apa sebab dia dipanggil dan diintergorasi. Kemungkinan lain ialah, jika ia pernah melakukan kejahatan yang lain, ia akan mengira soal kejahatan tersembunyi itulah (hiddern crime) menjadi sebab dia diintergorasi. Dengan demikian kejahatan interrogator atau pengusut mendapat durian runtuh. Interogasi diteruskan dengan soa itu sampai selesai. Tersangka yang bersalah jika ditanya seperti tersebut di atas mungkin akan menjawab: "Ya, saya tahu, karena Bapak mengira saya melakukan perbuatan anu". Dari sana diminta tersangka menerangkan apa saja yang dia ketahui tentang peristiwa itu, tentang korban, dan seterusnya. Kemudian semua atau salah satu taktik-taktik yang terseut di muka dapat dipergunakan.

2. Taktik yang kedua ialah seperti telah dikatakan di atas, kepada tersangka diminta menceritakan panjang lebar mengenai apa saja yang ia ketahui tentang peristiwa itu sendiri, tentang korban, dan orang-orang yang dicurigai. Dari jawaban tersangka dapat ditarik kesimpulan-kesimpulan tertentu, yang selanjutnya merupakan patokan untuk menyusun pertanyaan lebih lanjut. Kalau mereka yang dicurigai itu merupakan karyawankaryawan dari suatu perusaha atau instansi pemerintah, umpamanya tentang pencurian yang diduga dilakukan oleh atau atas petunjuk orang dalam sendiri, maka satu persatu mereka yang dicurigai itu diminta menceritakan siapa-siapa di antara kawan sejawatnya yang ia curigai. Dalam hal ini perlu cara bujukan yang menjamin kepadanya bahwa rahasia yang dimajukannya itu akan dijamin oleh interogato. Setelah itu mungkin mereka akan menyambut satu atau bberapa nama. Sebaliknya orang yang bersalah menurut pengalaman Inbau cs (Inbau, Ibid: 78) tidak akan menunjuk suatu nama dari merek ayng dicurigainya, kendatipun 
ditempuh segala cara oleh interalogator. ${ }^{41}$ Jika mereka enggan menyebut suatu nama, dianjurkannya membalikan pertanyaan itu menjadi "siapasiapa yang menurut tersangka, di antara kawan-kawannya itu, tidak bersalah dalam hal ini. Jadi tersangka diminta keterangannya sekarang mengenai hal siapa di antara kawannya itu yang dia pandang tidak bersalah. Orang yang tidak bersalah, sesudah didesak, akan menyebut ssatu atau beberapa nama yang dia pandang orang yang tidak melakukannya. Sebaliknya orang yang bersalah tidak akan menunjuk suatau namapun yang dia pastikan tidak melakukannya, yang dia lepaskan dari persangkaan ialah dirinya sendiri. Sesudah mendapat jawabanjawaban yang menunjuk salahnya tersangka, interogasi dapat dilanjutkan dengan pertanyaan-pertanyan yang lebih mendesak tersangka tersebut ke dalam lingkaran adegan kejadian itu sendiri. Segala taktik-taktik yang terdahulu (untuk tersangka yag sudah jelas kesalahannya) dapat dipergunakan dengan sebaik-baiknya. Tersangka harus dibiarkan bercerita terus, karena dari ceritanya yang penjang lebar itu, dapat ditimbul kontradiksi-kontradiksi, yang dapat dimanfaatkan oleh interagator sebaikbaiknya.

3. Selanjutnya hendaklah ditanyakan kepada tersangka segala aktivitasnya sebelum, selama dan sesudah terjadinya peristiwa itu. Dalam keterangannya yang panjang lebar nanti dapat diketahui salah atau tidaknya tersangka. ${ }^{42}$ Dalam rangka ini juga segala latar belakng tersangka hendaknya diusut, seperti pekerjaannya, hobinya, agamanya, partai politiknya dan segala yang mungin ada hubungannya dengan peristiwa atau korban. Pertanyaan hendaknya dimulai dari beberapa minggu atau bulan sebelum terjadinya delik, mengenai apa saja yang dilakukannya. Jika tersangka majukan alibi, hendaknya alibi itu diselidiki secara saksama, melalui suatu pengusutan khusus. Dan jika tidak cocok, maka kepada tersangka dimajukan tidak cocoknya keterangannya itu, jika misalnya ia menerangkan bahwa pada hari atau jam kejadian itu ia

\footnotetext{
${ }^{41}$ Ibid hlm. 82.
}

${ }^{42}$ Ibid hlm. 83. 
sementara bertemu di rumah temannya, maka diminta kepadanya menerangkan segala sesuatunya mulai tinggalkan rumah jam berapa, naik apa, melalui route mana singgah di mana dan jam berapa melalui jalan mana dan selanjutnya jam berapa tiba dirumah. Semua ini nanti dicocokkan dengan tempat dimana dia singgah, dan tempat mana dia singgah, dan tempat di mana dia bertemu, dan akhirnya istrinya yang harus ditanyai pertanyaan yang sama. Dalam hal demikian itu, jika tersangka ditahan, tiada kemungkinan konsultasi dengan keluarganya terlebih dahulu. Suatu pancingan yang bagus yang ditunjukan oleh Inbau cs (Ibid:96) mengenai alibi ini ialah sebagai berikut: jika tersangka misalnya mengatakan bahwa pada waktu kejadian itu, tersangka sementara bertamasya di pinggir laut, maka interrogator hendaklah mengatakan, saya juga bersama istri saya kebetulan ada di sana pada waktu itu, apakah saudara tidak melihat orang menolong seorang anak kcil yang hamper tenggelam di laut itu? Jika jawabannya mengatakan bahwa barangkali interrogator di tempat lain karena pada hari itu tidak ada kejadian seperti itu. Maka jawaban yang demikin ini merupakan jawaban dari orang yang menerangkan kebenaran. Pendeknya alibi yang dimajukan tersangka itu harus diselidiki mendalam, dan jika dia sekali membuat kebohongan maka terus dikejar sampai ia tiba pada pengakuan bersalah.

4. Selanjutnya jika interogaotr merasa mempunyai fakta-fakta tertentu yang menjurus hal itu ditanuakan, kalai nosa mendetail. Kalau tersangka agaknya mau berbohong, biarkan petunjuk apakah tersangka bersalah atauakah tidak. Kalau dia bersalah akan nyata jika dicocokan dengan fakta yang ada di tangan interrogator. ${ }^{43}$ Umpama hal ini terjadi dalam penyogokan, fakta yang dicari terlebih dahulu ialah apakah tersangka dalam waktu akhir-akhir ini pernah membelanjakan atau membayarkan atau menyimpan uang di bank, meminjamkan dan sebagaimana dalam jumlah besar. Kalau hal itu sudah ada di tangan interogator, hal itu

\footnotetext{
${ }^{43}$ Ibid hlm. 84.
} 
ditanyakan panjang lebar dari mana mendapat uang sebesar itu, berapa gajinya atau pendapatnya.

5. Dalam melaksanakan pertanyaan untuk dua tersangka, maka penyidik polri harus menggunakan taktik-taktik seolah-olah telah mengetahui tentang peristiwa yang dilakukan oleh tersangka sebelumnya.

6. Di samping itu tersangka dapat dikelabui dengan pertanyaan mengenai hal bukti salahnya tersangka, bukti-bukti mana yang sebenarnya tidak ada. Ini untuk memancing tersangka apakah mau mengungkapkan dengan terang benderang tentang peristiwa yang sebenarnya terjadi, jika ia mau mak ada kemungkinan ia bersalah. Karena orang yang tidak bersalah apaupn yang akan dihadapi tak pernah khawatir dihadapkan bukti-bukti oleh penyidik polri. Orang yang bersalah akan bertanya-tanya dalam hatinya dan rauk wajahnya akan memucat dan kegelisahan itu akan muncul sendiri dan/ atau tidak tenteram dalam memberikan jawaban kepada penyidik polri. ${ }^{44}$

\section{Viktimologi dan Kriminolodi dalam Penggunaan Metode "Memperdaya Tersangka" atau "Methods of Detecting Deception" atau Bisa Disebut "Association Method"}

Jika cara-cara dan taktik-taktik semuanya telah dipergunakan dala interogasi, dan belum juga dapat diketahui siapa atau siapa-siapa di antara yang dicurigai itu yang bersalah, dapat dipergunakan metode memperdayakan tersangka itu. Dalam hal ini pun nyata penggunaan psikologi dalm pengusutan atau penyidikan perkara. Metode ini berpangkal tolak pada dalil "pikiran dari pejabat akan selalu terlambt pada kejahatan itu sendiri”. Seperti dikatakan oleh Soderman (op.cit: 9). similarly the thought of the criminal are circling around the crime. He react unconsopisly to his secret thought when he hears something which is related to the crime. (sama dengan itu pikiran dari penjahat selalu berputar di sekitar kejahatan itu. Dia secara tidak sadar akan bereaksi dalam batinnya jika dia mendengar sesuatu yang ada sangkut pautnya dengan kejahatan itu).

${ }^{44}$ Ibid hlm. 85-86 
Kekurangan dari taktik modern ini ialah tersangka harus orang terpelajar setidak-tidaknya tidak buta huruf, hal mana masih sulit dijalankan seluruhnya di Indonesia. Lebih mudah dan lebih praktis dijalankan seluruhnya di Indonesia. Lebih mudah dan praktis cara Cina kuno yang disebut lebih dahulu.

Cara-cara kuno lainnya masih banyak, yang sering dipraktekkan oleh pemeriksa atau interrogator Indonesia. Pernah diceritakan oleh seorang Kepala Kepolisian Swapraja di zaman Belanda, suatu cara "kampungan" sebagai berikut: setelah tersangka yang dicurigai membunuh itu, diperiksa siang malam tanpa hasil, yang diselang-selangi dengan bujukan dan pukulan-pukulan, si pemeriksa mendapat akal baru. Dikatakannya baiklah, saya tidak melihat tanda-tanda yang kamu melakukan kejahatan itu, maukahkamu bertemu dan berbicara dengan istrimu?. Istrimu ada di rumah saya sekarang ini. Dia udah gelisah sekali ingin bciara denganmu.l nanti malam saya suruh tiba, sudah dipersiapkan suatu kamar. Sebelum tersangka ada satu ranjang dengan sprei yang menutupinya hamper menyentuh lantai. Di bawah ranjang itu bersembunyi seorang opas, yang akan bertindak sebagai tape recorder. Waktu itu, sekitar tahun 1936, bekum ada tape recorder. Lalu istri tersangka disuruh masuk lebih dahulu menunggu suaminya disana. Setelah suaminya masuk, terjadilah percakapan secara bebisik yang antara lain berkisar pada nasib suaminya tersebut. Tersangka mengatakan pemeriksaan sudah selesai, dan pemeriksa tidak berhasil membongkar perbuatannya.

Demikianlah sehingga segala sesuatu diceritakan kepada istrinya yang tertangkap oleh tape recorder hidup yang bersembunti di bawah ranjang dalam gulungan sebuah kasur pula. Setelah tersangka dikonfirmasi dengan si opas tadi, ia terpaksa mengaku segala perbuatannya. ${ }^{45}$

\section{E. Dalam Pelaksanaan Suatu Tindakan Hukum "Integorasi Terhadap Saksi" Dikaitkan dengan Sebuah Tinjauan Viktimologi dan Kriminologi}

Telah dikatakan di muka, bahwa petugas selalu harus berhati-hati dalam menerima laporan atau pengaduan, karena sering laporan atau pengaduan itu tidak benar baik karena disengaja, maupun tidak disengaja.

\footnotetext{
45 Ibid., hlm. 88.
} 
Jadi pengadu atau pelapor inilah yang terlebih dahulu harus diinterogasi mendalam, sebelum meningkat kepada saksi lainnya dan tersangka.

Kalau telah jekas bahwa sungguh-sungguh delik teelah terjadi, barulah meningkat kepada saksi lainya dan tersangka sendiri. Kesaksian makin hari makin penting artinya dalam pidana modern, berbanding dengan pengakuan tersangka yang sudah ditinggalkan diganti dengan keterangan tersangka (tertuduh) (Sahetapy, 1974).

Dalam acara pidana yang kuno, interrogator dalam pengusutn perkara selalu cenderung untuk merasa puas kalau sudah ada pengakuan tersangka.

Ini sesuai dengan sistem pemeriksaan dimana tersangka dipandang sebagai obyek, atau yang dikenal dengan asas inquisitoir. Segala daya ditujukan untuk memperoleh pengakuan itu, sehingga sering menjurus kepada penyiksaan.

Oleh karena asas inquisitor itu akan ditinggalkan dalam Hukum Acara Pidana yang akan dating dan dignti dengan asas accusatoir, artinya tersangka tidak lagi menjadi obyek pemeriksaan, tetapi sebagai "pihak" berhadapan dengan negar dimana ia pada pemeriksaan itu sudah dapat didampingi oleh penasihat hukum.

Oleh karena itu interrogator dalam cara pidana modern harus dibekalu dengan kecakapan baik di bidang sarana hukum, maupun di bidang sarana teknik termasuk di dalamnya tentu menyusun questionnaire (daftar pertanyaan) dan interview.

Mengenasi saksi, harus dikuasai lebih dahulu tentang perananan kesaksian dalam hukum acara pidana, sesudah itu teknik dan taktik interogasi terhadap saksi.

Seperti diketahui, yang dimaksud dengan kesaksian dalam hukum acara pidana, ialah apa yang dialami sendiri oleh saksi dalam peristiwa itu. Atau dapat juga dikatakan apa yang ditangkap oleh panca indera yang dalam bahasa Inggris disebut perceptions. Yang meliputi apa yang dilihat dengan matanya, bukan apa yang dilihat dengan batinnya, apa yang didengar dengn telinganya, apa yang dicium dengan hidungnya, apa yang dirasa dengan perasannya (feeling), bukan apa yang dirasa menurut anggapannya atau perasaanya, dan apa yang dirasa dengan lidahnya (taste). 
Dialami sendiri berarti bukan yang didengar dari orang lain, bukan apa yang dianalisa, bukan apa yang dia perkirakan (estimate). Oleh karena itu pertanyaanpertanyaan yang dimajukan tidak ada tempatnya berkisar pada pendapat analisa atau perkira saksi.

Pengalaman saksi yang berdasarkan panca inderanya itu dengan sendirinya relatif, karena panca indera manusia terbatas kemampuannya, lagi pula tidak sama tajamnya antara orang yang satu dengan yang lain. Dalam hal ini kita harus sangat berhati-hati.

Walaupun saksi berusaha bersungguh-sungguh untuk member keterangan yang sesuai dengan kebenaran, masih kadangkala keterangan itu benar sama sekali. $^{46}$

Dari satu persitiwa yang sama, saksi-saksi sering memberi keterangan yang belainan. Hal ini akan lebih sulit lagi jika waktu kejadian dan waktu interogasi jaraknya agak berjauhan. Karena penca indera yang terbatas kemampuanyya itu menjadi relatif lagi karena harus dihubungkan dengan faktor ingatan manusia yang sangat terbatas pula.

Yang paling tidak pasti dari semuanya itu ialah perasa atau perbaaan (feeling). Jika saksi mengenali suatu benda atau orang di gelap-gulita, hanya karena meraba atau menyentuhnya saja, hal itu sangat meragukan kita. Lain halnya pada orang buta karena perasaannya atau perabaannya sangat tajam, karena sudah terlatih sekali dengan panca inderaya itu.

Begitu pula dengan penciuman, kadang-kadang tidak benar sama sekali. Pernah terjadi di Swedia Utara seorang pembantu rumah tangga ditahan karena tuduha telah membunuh bayi yang baru saja dilahirkannya, tuduhan itu didasarkan kepad laporan beberapa tetangganya bahwa telah tercium bau seperti daging terbakar dari kamar pembantu itu. Pembantu itu tekah sampai kejadian pembakaran itu. Pembakaran itu sendiri tidak dapat diperiksa lagi, karena telah dibersihkan. Setelah diadakan pemeriksaan yang seksama oleg dokter terhadap pembantu itu, ternyata dapat memberikan keterangan apa-apa mengenai hal itu. Dengan sendirinya ia segera dilepaskan.

\footnotetext{
${ }^{46}$ Ibid., hlm. 90.
} 
Dari semua angora panca indera manusia, penglihatan matalah yang paling berarti bagi kesaksian, walaupun terbatas juga, terutama kalau waktunya telah agak lama, karena harus dihubungkan dengan daya ingat manusia.

Oleh karena itu, hanya sarana teknik (technical nature) yang mempunyai nilai mutlak kata Soderman. Ini pun menurut hemat kami tidaklah mutlak. SusioGamino menceritakan bahwa pernah terjadi pada pemeriksaan abu dari tempat sampah didapat tulang yang menurut pemeriksaan teknis adalah tulang manusia, pada hal kemudian terbukti tulak babi (Susio-Gamino, 1960: 70).

Di samping terbatasnya sebenarnya nilai penyaksian panca indera manusia, masih ada lain bagi kesulitn dalam menginterogasi saksi, yaitu banyak orang enggan atau tidak mau menjadi saksi. Biasanya orang enggan atau tidak mau menjadi saksi karena: Pertama, karena banyak orang tidak mau terlibat dalam urusan pengadilan, dan tidak mau diperguncingkan disurat-surat kabar. Kedua, karena kalau orang menjadi saksi, ia akan kehilangan waktu dan uang, selalu ia harus mondar-mandir antara kantor polisi, kejaksaan dan pengadilan. Ketiga, mungkin orang itu simpati terhadap tersangka atau ada hubungan keluarga, pekerjaan dan sebagainya. ${ }^{47}$

Di asia ada dikenal suatu legal culture seperti dikenal di Korea (saya kira Indonesia pun demikian), bahwa berpekara itu sebenarnya tidak membawa suatu kedamain. Seperti ditulis oleh seorang Korea, Hahn Pyong Choon, dalam karangannya: Religion and law in Korea (Dikutip dari karangan Sutjipo Rahardjo,S.H., beberapa segi dari studi tentang hukum dan masyarakat, dalam HUKUM, Nomor 1 Tahun 1), sebagai berikut: When Western law undertakes an investigation, the primary purpose is prosecutin and punishment, and the result is further disruption of social harmony rather than a speedy restoration of jeopardized concord. It is rare that the Korean will cooperate readilt with facts. Factual information will be forth coming only if it will assist a quick reestablishment of equilibrium. Berpekara bagi mereka sama dengan pernyataan perang; apalagi seorang membawa orang lain ke depan pengadilan, maka sesunggunya ia telah menyatakan perang kepada orang itu.

\footnotetext{
${ }^{47}$ Ibid hlm. 91-92.
} 
Oleh karena itu, interrogator harus sadar akan semua ini dalam menghadapi seorang yang akan dijadikan saksi dalam suatu perkara kriminal.

Oleh karena adanya keenganan orang untuk menjadi saksi, maka perlu dipikirkan secara seksama pertanyaan-pertanyaan yang akan dimajukan, terutama dalam usaha mencari saksi di tempat kejadian perkara. Misalnya dalam perkara lalu-lintas seperti tabrakan dan sebagainya, dalam usaha mencari saksi di antara khalayak ramai itu, tetapi langsung kepada seseorang yang ada disitu yang diperkirakan melihat kecelakaan yang bersangkutan, dan mengatakan "tolong terangkan sedikit apa yang saudara lihat tadi”. Kalau dia bersedia, barulah dicatat, dan kemudian nanti dipanggil sebagai saksi (pasal 522 KUHP).

Jika dalam interogasi saksi enggan memberikan keterangan karena takut balas dendam dari tersangka, dapat diterangkan kepadanya bahwa yang penting saksi menerangkan kebenaran, tidak menambah-nambah untuk kepentingan sendiri dan menerangkan apa yang dialaminya secara jujur, tidak akan ada balas dendam dari tersangka. Siapakah polisi, jaksa atau hakim yang telah jujur telah disakiti oleh seorang terhukum atau kawan-kawannya. ${ }^{48}$

Jika keadaan sedemikian pentingnya, rumah kediaman saksi dapat diberikan penjagaan polisi.

Kelau ternyata saksi tidak mau memberikan kesaksian karena simpati atau kawan, atau keluarga, atau karena adanya kepentingganya pada tersangka, maka pemeriksaannya atau interogasinya dilakukan sebagaimana memeriksa atau interogasi tersangka. Bahkan pernah terjadi seorang saksi karena demikian setia dan loyalnya kepada atasannya seorang direktur PT bernama H.M) yang telah melakukan penyelundupan, ia sendiri yang mengakui segala-galanya mengenai perbuatan penyelundupan itu. Akhirnya karena ada saksi lainnya, atasannya pun tetap di bebaskan pada tingkat appel (Pengadilan Tinggi).

Pada akhirnya, saksi yang diperiksa sebagai dakwa akan sadar, dan memberikan keterangan yang sebenarnya. ${ }^{49}$

KUHP memberikan defenisi penyelidikan sebagai berikut:

${ }^{48}$ Ibid hlm. 92-93.

${ }^{49}$ Ibid hlm. 93 
"Penyelidikan adalah serangkaian tindakan penyelidikan untuk mencari dan menemukan suatu peristiwa yang diduga sebagai tindak pidana guna menentukan dapat atau tidaknya dilakukan penyidikan menurut cara yang diatur dalam undangundang ini"

Dalam suatu peristiwa pidana (kejahatan) seorang yang menjadi korban ataupun seseorang yang diduga melakukan suatu tindak pidana terlebih dahulu harus mengetahui tentang wewenang ataupun perincian wewenang penyidik bahwa diatur dalam pasal berapakah tentang wewenang penyidikan, alasannya adalah agar lebih jelas dapat diketahui apakah betul-betul penyidik ini adalah seorang polisi ataukah suruhan dari oknum-oknum yang merasa mempunyai kekuasaan, jabatan ataupun seseorang yang memiliki materi yang berlimpah dengan demikian apakah mereka berpura-pura menjadi seorang penyidik palsu.

Untuk itu dalam tulisan buku yang diberi judul "Penghukuman Tanpa Hakim.” akan menjelaskan secara rinci tujuan dan maksudnya, agar seseorang yang tersangka maupun yang menjadi korban akan terang benderang dapat mengetahui apa itu penyelidikan, penyidikan. Untuk itu, rincian wewenang penyelidik adalah diatur dalam Pasal 5 KUHP yang berbunyi sebagai berikut;

(1) Penyelidik sebagaimana dimaksud dalam Pasal 4:

a. Karena kewajibannya mempunyai wewenang:

1. Menerima laporan atau pengaduan dari seorang tentang adanya tindak pidana;

2. Mencari keterangan dan barang bukti;

3. Menyuruh berhenti seseorang yang dicurigai dan menanyakan serta memeriksa tanda pengenal diri;

4. Mengadakan tindakan lain menurut hukum yang bertanggung jawab.

b. Atas perintah penyidik dapat melakukan tindakan berupa:

1. Penangkapan, larangan meninggalkan tempat, penggeledahan dan penyitaan;

2. Pemeriksaan dan penyitaan surat;

3. Mengambil sidik jari dan memotret seseorang;

4. Membawa dan menghadapkan seseorang pada penyidik. 
(2) Penyidik membuat dan menyampaikan laporan hasil pelaksanaan tindakan sebagimana tersebut pada ayat (1) huruf a dan huruf $b$ kepada penyidik.

Dalam penjelasan pasal itu, yang dijelaskan hanya huruf a angka (4) yaitu disebut "tindakan lain." Yang dimaksud dengan "tindakan lain" adalah tindakan dari penyidik untuk kepentingan penyelidikan dengan syarat-syarat sebagai berikut;

a. Tidak bertentangan dengan suatu aturan hukum;

b. Selaras dengan kewajiban hukum yang mengharuskan dilakukannya tindakan jabatan;

c. Tindakan itu harus patut dan masuk akal dan termasuk dalam lingkungan jabatannya;

d. Atas pertimbangan yang layak berdasarkan keadaan memaksa

e. Menghormati hak asasi manusia.

Untuk itu KUHAP membedakan istilah penyidikan dan penyelidikan seperti telah diuraikan dimuka, lebih tepat istilah "pengusutan" padanan istilah Belanda opsporing inggris investigation dari pada penyidikan yang dipakai sekarang oleh perundang-undangan kita, termasuk KUHAP.

Walaupun kedua istilah "penyidikan" dan" penyelidikan" berasal dari kata yang sama yaitu "sidik," dengan pengertian yang sama, hanya sisipan "el" pada kalimat penyelidikan yang mana hal tersebut hanya berfungsi memperkeras arti (banyak menyidik), namun KUHAP membedakan keduanya dalam fungsi yang berbeda.

Penyidikan sebagai padanan istlah opsporing atau investigation seadangkan penyeludikan menjadi padanan istilah reserse.

Menurut KUHAP "Penyidikan" diartikan "serangkaian tindakan penyidik dalam hal dan menurut cara yang diatur dalam undang-undang ini untuk mencari serta mengumpulkan bukti yang dengan itu membuat terang tentang tindak pidana yang terjadi dan guna menemukan tersangkanya."

Dengan demikian, pula diketahui wewenang penyelidikan dan penyidikan itu menurut KUHAP. Bagian-bagian pengusutan atau penyidikan yang berkaitan dengan acara pidana ialah:

${ }^{50}$ Ibid., hlm. 95. 
1. Ketentuan tentang alat-alat penyidik.

2. Ketentuan tentang diketahui terjadinya delik.

3. Pemeriksaan di tempat kejadian.

4. Pemanggilan tersangka atau terdakwa.

5. Penahanan sementara.

6. Penggeledahan. ${ }^{51}$

7. Pemeriksaan atau interogasi.

8. Berita acara (pengeledahan, interogasi dan pemeriksaan di tempat).

9. Penyitaan.

10. Penyampaian perkara.

11. Pelimpahan perkara kepada penuntut umum dan pengembaliannya kepada penyidik untuk disempurnakan.

Telah diketahuinya bahwa dalam terjadinya delik ada empat kemungkinan antara lain adalah sebagai berikut :

1. Kedapatan tertangkap tangan (Pasal 1 ayat (19) KUHAP).

2. Karena laporan (Pasal 1 ayat (24) KUHAP).

3. Karena pengaduan (Pasal 1 ayat (25) KUHAP).

4. Diketahui sendiri atau pemberitahuan atau cara lain sehingga penyidik diketahui terjadinya delik seperti baca di surat kabar, dengar di radio, dengar orang bercerita dan selanjutnya.

Dengan demikian untuk mengetahui lebih jelas tentang definisi dari pada “tertangkap tangan" pada Pasal 1 ayat (19) KUHAP tersebut, pengertian tertangkap tangan meliputi:

1. Tertangkap pada waktu sedang melakukan tindak pidana;

2. Tertangkap segera sesudah beberapa saat tindak pidana itu dilakukan;

3. Tertangkap sesaat kemudian diserukan oleh khalayak ramai sebagai orang yang melakukan delik; ${ }^{52}$

4. Tertangkap sesaat kemudian padanya ditemukan benda yang diduga keras telah dipergunakan untuk melakukan tindak pidana itu yang menunjukkan 
bahwa ia adalah pelakunya atau turut melakukan atau membantu melakukan tindak pidana itu.

Penulis mencari ketentuan KUHAP yang sama dengan Pasal 45 itu namun tidak berhasil. Dalam Pasal 45 HIR itu diatur tentng laporan dan pengaduan. Antara keduanya ada perbedaan:

a. Pengaduan hanya dapat dilakukan oleh orang tertentu saja yang disebut dalam undang-undang dan dalam kejahatan tertentu saja. Laporan dapat dilakukan oleh siapa saja terhadap semua macam delik.

b. Pengaduan dapat ditarik kembali sedangkan laporan tidak dapat. Bahkan seseorang yang melaporkan orang lain telah melakukan delik padahal tidak benar, dapat dituntut melakukan delik laporan palsu.

c. Pengaduan mempunyai jangka waktu tertentu untuk mengajukan (Pasal 74 KUHAP) sedangkan laporan dapat dilakukan setiap waktu.

d. Sebenarnya pengaduan itu merupakan suatu permintaan kepda penuntut umum agar tersangka dituntut.

Perlu diperhatikan bahwa pengaduan itu ada dua macam:

1. Yang absolute (absolute klachtdelikt) dan

2. Yang relative (relative klachtdelict).

Yang tersebut pertama hanya dapat dilakukan penyidikan jika telah ada pengaduan. Jadi, delik itu sendiri menentukan apakah merupakan delik aduan ataukah tidak. Umpama: Pasal 284 KUHP (mukah). 287 KUHP (bersetubuh dengan perempuan di bawah umur), 293 KUHP (membujuk anak di bawah umur untuk berbuat cabul), 310-321 KUHP (penghinaan).

Yang tersebut kedua pada umumnya deliknya sendiri merupakan delik biasa, tetapi ditinjau dari orang yang melakukannya, maka menjadi delik aduan. Oleh karena itu, berbeda dengan yang tersebut pertama, maka pada yang tersebut kedua ini penyidikan dapat dilakukan meskipun tidak ada pengaduan. Hanya pada tingkat penuntutan, barulah diperlukan adanya pengaduan yang tertulis yang dilampirkan pada berkas perkara. Kalau pengaduan tertulis itu tidak dilampirkan, maka hakim dapat menolak tuntutan jaksa (niet ontvangkelijk verklaring vanhet $O M$ ). ${ }^{53}$

53 Ibid hlm. 100-101 
Penulis menjelaskan tentang beberapa hal yang patut diketahui tentang lamanya tahapan penahanan dari tingkat Penyidikan , Penuntutan samapai dengan tahap pada pengadilan, Banding, Kasasi. Untuk itu, para pihak dapat mengetahui agar jangan menjadi korban dari suatu peristiwa hukum.

Dengan demikian dapat diperinci penahanan dalam hukum acara pidana Indonesia adala sebagai berikut, sebagaimana telah tertuang dibawah ini:

1. Tahap pengusutan (penyidikan), yaitu;

a. Penahanan oleh penyidik atau pembantu penyidik yaitu selama 20 hari.

b. Perpanjang oleh penuntut Umum yaitu selama 40 hari

2. Tahap Penuntutan (Jaksa penuntut Umum), yaitu;

a. Penahanan oleh (JPU) Jaksa Penuntut Umum, yaitui selama 20 hari

b. Perpanjang oleh ketua pengadilan negeri yaitu selama 30 hari

3. Tahap pada Pengadilan Negeri yaitu;

a. Penahanan oleh hakim pengadilan negeri yaitu selama 30 hari

b. Perpanjang oleh ketua pengadilan negeri yaitu selama 60 hari

4. Tahap Banding

a. Penahanan oleh hakim pengadilan tinggi yaitu selama 30 hari

b. Perpanjangan oleh ketua pengadilan tinggi yaitu selama 60 hari.

5. Tahap Kasasi

a. Penahanan oleh Mahkamah Agung yaitu selama 50 hari

b. Perpanjangan oleh Ketua Mahkamah Agung yaiu selama 60 hari

Jadi, seseorang tersangka atau terdakwa dari pertama kali ditahan dalam rangka penyidikan sampai pada tingkat kasasi haya dapat ditahan paling lama : 400 hari. $^{54}$

Tetapi perlu diperhatikan adanya ketentuan pengecualian tentang penahanan yang diatur dalam Pasal 29 KUHAP yang mengatakan bahwa jangka waktu penahanan sebagaimana terbuat pada Pasal 24, Pasal 25, Pasal 26, Pasal 27 dan Pasal 28, guna kepentingan pemeriksaan, penahanan terhadap tersangka atau terdakwa dapat diperpanjangan berdasar alasan yang patut dan tidak dapat dihindarkan karena:

${ }^{54}$ Ibid hlm. 109 
a. Tersangka atau terdakwa menderita gangguan fisik atau mental yang berat, yang dibuktikan dengan surat keterangan dokter, atau

b. Perkara yang sedang diperiksa, diancam pidan penjara Sembilan tahun atau lebih.

Apa yang dimaksud dengan kata-kata "alasan yang patut dan tidak dapat dihindarkan", tidak dijawab oleh undang-undang. Menurut pendapat penulis, katakata itu berlanjut dengan kalimat berikutny yang tersebut pada butir a dan b Artinya kata-kata tersebut tidak berdiri sendiri.

Yang dijelaskan oleh penjelasan Pasal 29 itu ialah pengertian "kepentingan pemeriksaan", pemeriksaan yang belum dapat diselesaikan dalam waktu penahanan yang ditentukan dan "gangguan fisik atau mental yang berat". Keadaan tersangka atau terdakwa yang tidak menungkinkan untuk diperiksa karena alasan fisik dan mental.

Dalam pasal 29 ayat (2) KUHAP ditentukan lamanya perpanjuangan yang dimaksud dalam ayat (1) tersebut, yaitu tiga puluh hati yang dapat diprpanjang lagi tiga puluh hari. Jadi, jumlahnya enam puluh hari.

Perpanjangan tersebut berlaku pada kelima tingkat yaitu, penyidikan (Pasal 24), penuntutan (Pasal 25), pemeriksaan pengadilan negeri. (Pasal 26), pemeriksaan banding (Pasal 27) pemeriksaan kasasi (Pasal 28). Dengan demikian bagi delik yang diancam pidana penjara Sembilan tahun atau lebih dapat ditahan cukup lama juga. Delik-delik semacam itu banyak pula, seperti kejahatan terhadap keamanan Negara, pembunuhan, delik ekonomi yang "dapat mengacaukan perekonomian dalam masyarakat", delik korupsi, delik subversi, delik narkotika, delik rahasia atom dan lain-lain.

Pejabat yang berwewenang memperpanjang penahanan sesuai dengan Psal 29 ayat (3) berbeda dengan yang berwenang memperpanjang yang biasa. Dalam ayat ini ditentukan bahwa:

a. Pada tingkat penyidikan dan penuntutan diberikan oleh ketua pengadilan negeri.

b. Pada tingkat pemeriksaan di pengadilan negeri diberikan oleh ketua pengadilan tinggi. 
c. Pada tingkat pemeriksaan banding diberikan oleh Mahkamah Agung

d. Pada tingkat kasasi diberikan oleh Ketua Mahkamah Agung.

Dalam hal penggunaan wewenang perpanjangan penahanan tersebut KUHAP member batas-batas:

1. Tersangka atau terdakwa dapat mengajukan keberatan dalam tingkat penyidikan dan penuntutan kepada ketua pengadilan tinggi, pemeriksaan pengadilan negeri dan pemeriksaan banding kepada Ketua Mahkamah Agung (Pasal 29 ayat (7) KUHAP).

2. Tersangka atau terdakwa berhak minta ganti kerugian sesuai dengan ketentuan yang dimaksud dalam Pasal 95 dan Pasal 96 apabila tenggang waktu penahanan sebagaimana etrsebut pada Pasal 24, Pasal 25, Pasal 26, Pasal 27 dan Pasal 28 atau perpanjangan penahanan sebagaimana tersebut pada Pasal 29 ternyata tidak sah (Pasal 30 KUHAP). ${ }^{55}$

3. Menurut pendapat penulis, kata-kata pada Pasal 30 KUHAP tersebit : “apabila tenggang waktu penahanan”...”ternyata tidak sah”, kurang tepat, karena bukan tenggang waktunya yang tidak sah, tetapi dasar hukumnya atau cara melakukannya.

\section{Penjelasan Tentang Aliran-Aliran dalam Ilmu Krinologi}

Aliran-aliran dalam Kriminologi ada 4 aliran antara lain adalah;

\section{Aliran Klasik.}

Aliran klasik merupakan label umum untuk sekelompok pemikir tentang kejahatan dan hukuman pada abd 18 dan awal abad 19. Anggota paling menonjol dari kelompok pemikir tersebut antara lain Cesare Beccaria dan Jeremy Bentham. Dua pemikir ini mempunyai gagasan yang sama, bahwa perilaku kriminal bersumber dari sifat dasar manusia sebagai makhluk hedonistic sekaligus rasional. Hedonistic, karena manusia cenderung bertindak demi kepentingan diri sendiri. Sedangkan rasional, karena mampu memperhitungkan untung rugi dari perbuatan tersebut bagi dirinya.

Dasar dari tindakan individu yang hedonistic adalah kepentingan diri sendiri. Seperti dikatakan Bentham, alam telah menempatkan manusia di bawah kendali

\footnotetext{
${ }^{55}$ Ibi., hlm. 111.
} 
dua penguasa, yakni suka dan duka. Untuk dua hal itulah manusia berpikir tentang apa yang sebaiknya dilakukan, dan apa yang mesti dilakukan. Dua hal itu juga menentukan apa yang kita lakukan, apa yang kita katakana, dan apa yang kita pikirkan. ${ }^{56}$

Menurut Bentham, seluruh tindak tanduk manusia, disadari ataupun tidak, sesungguhnya tertuju untuk meraih kebahagiaan itu. Apa yang cocok digunakan, atau cocok untuk kepentingn individu, adalah apa yang cenderung untuk memperbanyak kebahagiaan. Demikian juga, apa yang cocok untuk kepentingan masyarakat, adalah apa yang cenderung menambah kesenangan individu-individu yang merupakan anggota masyarakat itu. Orang-orang biasanya akan bertindak untuk keuntungan diri mereka sendiri, dan akan berusaha untuk meminimalkan rasa sakit atau biaya. Inilah yang mesti menjadi titik tolak dalam menata hidup manusia, termasuk hukum.

Menurut aliran klasik ini, seorang individu tidak hanya hedonis tetapi juga rasional, dan dengan demikian selalu mengkalkulasi untung rugi dari tiap perbuatannya, termasuk ketika melakukan kejahatan. Kemampuan ini memberikan mereka tingkat kebebasan tertentu dalam memilih tindakan yang akan diambil apakah melakukan kejahatan atau tidak.

Oleh karena itu, aliran ini berfaham indeterminisme mengenai kebebasan kehendak (free will) manusia yang menekankan pada perbuatan pelaku kejahatan. Mengingat kehidupan sosial diikat oleh kontrak sosial, maka setiap perbuatan yang melanggar norma-norma sosial yang berlaku, dipandang sebagai tindakan mengkhianati kontrak sosial itu sendiri. Pengkhianatan terhadap kontrak sosial tersebut harus dihukum setimpal dengan kerugian yang ditimbulkan. Aliran klasik, dengan demikian, menganjurkan penghukuman yang bersifat retributif dan represif.

Aliran klasik memiliki intellectual baground soal "inteleectualism" dan "rationalism" dari "The Social Contract Writers" (Hobbes, John Locke, Montesquieu, Voltaire dan Rousseau). Teori kontrak sosial meyakini bahwa individu menyerahkan kebebasan atau kemerdekaanya secukupnya kepada Negara dan oleh karenanya hukum harusnya hanya ada untuk melindungi dan 66

${ }^{56}$ Indah Sri Utari. Aliran dan Teori dalam Kriminologi. Penerbit. Thafa Media, Yogyakarta, 2012, hlm.. 
mempertahankan keseluruhan kemerdekaan yang dikorbankan terhadap persamaam kemerdekaan yng dilakukan oleh orang lain. Prinsip dasar yng digunakan sebagai pedoman dalam kontrak sosial orang sebanyak-banyaknya.

Dalam konteks keutamaan kontrak sosial itulah, maka dalam aliran klasik muncul gagasan tentang hukuman yang retributif. Hukuman retributif mengandaikan pemidanaan sebagai ganjaran negatif terhadap perilaku menyimpang yang dilakukan oleh warga masyarakat sehingga ini melihat pemidanaan hanya sebagai pembalasan terhadap kesalahan yang dilakukan atas dasar tanggung jawab moral pelaku sebagai anggota masyarakat yang melanggar kontrak yang telah dibuat bersama.

Jadi, pemidanaan merupakan pembalasan atas kesalahan yang telah dilakukan sehingga berorientasi pada perbuatan dan terletak pada terjadinya kejahatan itu sendiri. Sanksi dijatuhkan semata-mata karena orang telah melakukan sesuatu kejahatan yang merupakan akibat mutlak yang harus ada sebagai suatu pembalasan kepada orang yang melakukan kejahatan sehingga sanksi bertujuan untuk memuaskan tuntutan keadilan.

Sementara itu, Jeremy Bentham melihat suatu prinsi baru yaitu utilitarian yang menyatakan bahwa suatu perbuatan tidak dinilai dengan sistem yang irrasional yang absolut, tetapi melalui prinsip-prinsip yang dapat diukur. Bentham menyatakan bahwa hukum pidana jangan dijadikan sarana pembalasan tetapi untuk mencegah kejahatan.

Padangan untilitarian melihat pemidanaan dari segi menfaat atau kegunaannya dimana yang dilihat adalah situasi atau keadaan yang ingin dihasilkan dengan dijatuhkannya pidana itu. Di satu pihak, pemidanaan dimaksudkan untuk memperbaiki sikap atau tingkah laku terpidana dan di pihak lain pemidanaan itu juga dimaksudkan untuk mencegah orang lain dari kemungkinan melakukan perbuatan yang serupa. Pandangan ini dikatakan berorientasi ke depan (forwar looking) dan sekaligus mempunyai sifat pencegahan (deterrence).

Beccarian merupakan salah seorang tokoh yang memperjuangkan kembali peninjauan terhadap perbuatan-perbuatan yang dinamakan kejahatan dan hukuman atas pebuatan-perbuatan itu. Oleh karena itu, mazhab ini lebih penting ditinjau dari 
sudut penology (the treatment of crimes). Beccaria adalah seorang ahli ekonomi dan ilmu pasti. Perhatiannya tertuju pada acara pidana dan pelaksanaan hukuman. Bukunya yang terkenal adalah "Essay on Crime and Punishment" (1764).

Beberapa prinsip dari Beccaria mengenai sistem keadilan dalam buku tersebut di atas sebagai berikut:

a. Pembentukan suatu masyarakat yang didasarkan pada kontrak (contrakcual society) untuk menghindarkn perang dan kekacauan. Jadi, penjumlahan atau akumulasi dari semua kebebasan individu merupakan atau dijelmakan menjadi kekuasaan Negara, dan ini diserahkan kepada seseorang penguasa, sebagai administrator yang sah. Akan tetapi, kekuasaan-kekuasaan yang diserahkan tersebut perlu pula diatur untuk melindungi dan mempertahankannya dari keserakahan individu. Selain itu, perlu pula pengaturan hukum terhadap mereka yang melanggar UndangUndang.

b. Sumber hukum adalah undang-undang dan bukan hakim. Oleh karena itu, hanya undang-undang yang dapat menentukan hukuman bagi kejahatan. Kekuasaan untuk membentuk undang-undang pidana hanya ada pada pembuat undang-undang. Hakim tidak dapat, dengan alasan apapun juga, menjatuhkan hukuman yang tidak ditentukan oleh undang-undang atau memberikan hukuman lebih berat dari yang ditentukan oleh undangundang.

c. Tugas sebenarnya dari hakim hanyah menentukan kesalahan seseorang, hukuman adalah urusan undang-undang. Hakim tidak diperbolehkan menafsirkan undang-undang pidana. Sekali undang-undang telah ditetapkan maka tugas hakim hanyalah menentukan apakah suatu perbuatan sesuai atau tidak dengan aturan yang tertulis.

d. Hanya Negara (penguasa) yang berhak untuk menghukum. Hak penguasa untuk menghukum didasarkan pada suatu kebutuhan yang mutlak (absolute necessity) yakni membela kebebasan masyarakat (umum) yang telah dipercayakan kepadanya, dan melindungi masyarakat dari keserakahan individu. 
e. Harus ada suatu skala kejahatan dan hukuman. Sakala harus dibuat dengan ketentuan: pada ujung yang pertama adalah perbuatan-perbuatan yang langsung akan menghancurkan masyarakat, dan pada ujung lainnya adalah perbuatan-perbuatan yang langsung akan menghancurkan masyarakat, dan pada ujung lainnya adalah perbuatan-perbuatan kecil beripa ketidak adilan terhadap seseorang anggota masyarakat. Dia antara kedua ujung inilah dikumpulkan semua perbuatan yang bertentangan dengan kesejahteraan masyarakat yang disebut kejahatan.

f. Sengsara (sakit) dan kesenangan adalah dasar dari motif-motif manusia (human motivation). Demikian pula halnya dalam perbuatan-perbuatan keagamaan. Pembuat undang-undang telah menentukan hadiah dan hukuman untuk setiap orang.

g. Perbuatan seseorang dan bukan "kesalahannya" (intent), yang merupakan ukuran dari besar kerugian akibt kejahatan.

h. Prinsip dasar dari hukum pidana terletak pada sanksi-sanksi yang positif.

Di samping delapan point di atas, Beccaria juga menganjurkan beberapa hal penting, antara lain:

- Mencegah kejahatan adalah lebih penting dari pada menghukum kejahatan,

- Hukuman hanya menarik kalau ia mencegah kejahatan,

- Ia menginginkan agar seyogyanya semua undang-undang atau positif diumumkan agar semua warga mengetahuinya,

- Dalam hukuman, yang terpenting bukan keras atau beratnya tetapi ketegasan dan ketepatan yang mempunyai efek preventif yang terbesar,

- Harus diusahakan penggunaan pidana penjara dengan lebih banyak,

- Penjara-penjara harus diperbaiki.

\section{Aliran Positif}

Aliran modern atau aliran positif muncul pada abad ke-19 yang bertitik tolak pada faham determinisme tentang manusia. Faham ini menggantikan doktrin kebebasan berkehendak (the doctrine of free will). Bagi aliran positif, manusia dipandang tidak mempunyai kebebasan berkehendak, tetapi dipengaruhi oleh kondisi internal dan eksternal manusia itu sendiri. 
Aliran positif dalam kriminologi memandang bahwa perilaku manusia ditentukan oleh faktor-faktor diluar kontrolnya-baik yng berupa faktor biologis maupun cultural yang dapat mempengaruhi manusia untuk berbuat sesuatu di luas kuasanya. Artinya manusia dipandang tidak memiliki kebebasan untuk mengikuti dorongan keinginannya dan intelegensinya dalam menentukan pilihan untuk berbuat sesuatu secara rasional sebagaimana dikonsepsikan dalam aliran klasik. Sebaliknyalah, menurut aliran positif, manusia dipandang sebagai makhluk yang dibatasi atau ditentukan oleg berbagai factor di luar dirinya yang berupa perangkat biologis, psikologis, dan situasi kulrutal dalam berbuat sesuatu, baik yang berupa kebaikan ataupun kejahatan.

Ada tiga segmen teori dalam aliran positif. Pertama segeman yang bersifat biologis seperti pemikiran Lambrosian mengenai cirri fisik penjahat. Kedua, segmen yang bersifat psikologis seperti antara lain pemikiran Hans Eysenck tentang pshycopatic factors antara lainneuroticism, psychoticism, psychopathic yang menyebabkan seseorang cenderung melakukan kejahatan. Ketiga, segmen social positivism seperti terdapat dalam pemikiran Adolphe Quetelet, Rawson, Henry Mayhew, dan Durkheim mengenai societal factors antara lain poverty, membership of subcultures, law level of education, crowded cities, distribution of wealth sebagai factor pendorong terjadinya kejahatan.

Bagi aliran positif, semua factor-faktor tersebut merupakan unsure utama yang mempengaruhi perbuatan seseorang. Oleh karena itulah, apabila didapati fenomena kejahatan yang dilakuukan seseorang, maka menurut aliran ini, terjadinya kejahatan tersebut dikarenakan pelaku kejahatan mendapat pengaruh dari factor-faktor tertentu di atas (antara lain menurut Guerry karena factor kemiskinan, rendahnya tingkat pendidikan dan kesempatan; atau menurut Quetelet karena factor rendahnya tingkat pendidikan, penyakit moral, kemiskinan, pengganguran dan kesempatan yang minim).

Namun, jika didapati fakta berupa fenomena dimana terdapat seseorang yang dipengaruhi oleh factor-faktor tersebut tetapi tidak melakukan kejahatan, maka menuruty aliran ini, hal tersebut dapat dikatakan sebagai pengecualian karena 
konseop yang dianut aliran ini yaitu sebagian besar orang akan berbuat jahat manakala dipengaruhi faktor-faktor dimaksud.

Mengenai penghukuman, aliran ini menganjurkan agar pelaku tidak perlu dihukum, sebab ia hanyalah korban keadaan yang berada di luar kontrolnya sebagai individu. Langkah yang lebih strategis adalah, melakukan pembenahan sistem lingkungan (sosial,ekonomi,budaya,politik) secara holistic. Disamping itu, melakukan terapi khusus terhadap pelaku yang bermasalah secara psikologis dan biologis.

Kalaupun diperlukan penghukuman terhadap pelaku, maka aliran ini menghendaki adanya individualisasi pidana yang bertujuan untuk mengadakan resosialisasi pelaku. Aliran ini menolak penggunaan fiksi-fiksi yuridis dan teknikteknik yuridis yang terlepas dari kenyataan social. Sebab seperti dikatakan Marc Ancel, salah satu tokoh aliran modern, kejahatan merupakan masalah kemanusiaan dan masalah sosial yang tidak mudah begitu saja dimasukkan ke dalam perumusan undang-undang.

Pelopor aliran positivis ini adalah Cesare Lombrosso (1835-1909), yaitu seorang dokter dari Italia yang mendapat julukan Bapak Kriminologi Modern melalui teorinya yang terkenal yaitu Born Criminal. Teori Born Criminal ini dilandasi oleh teori evolusi dari Darwin. Dengan teorinya tersebut Lombrosso membantah mengenai "free will" yang menjadi dasar aliran klasik dan mengajukan konsep determinisme. Inti dari ajaran Lombrosso yaitu: 1) Penjahat adalah orang yang memiliki bakat jahat; 2) Bakat jahat tersebut diperoleh dari kelahiran (born criminal); 3) Bakat jahat dapat dilihat dari cirri-ciri biologis (atavistic stifmata) seperti dahi yang sempit dan melengkung kebelakang; rahang yang besar dan gigi tajam; berbadan tegap; tangan lebih panjang; bibir tebal; hidung tidak mancung; dan lain sebagainya.

Untuk diketahui. Lombrosso membagi penjahat dalam empat golongan, yaitu born criminal (orang yang memang sejak lahir berbakat menjadi penjahat), insane criminal (orang termasuk dalam golongan orang idiot, imbecil, dan paranoid); criminaloid (pelaku kejahatan yang berdasarkan pada pengalaman yang terus 
menerus sehingga mempengaruhi pribadinya); dan criminal of passion (orang yang melakukan kejahatan karena cinta, marh ataupun karena kehormatan).

Lambroso dilahirkan dari keluarga Yahudi di Venesia, dididik sebagai dokter dan kemudian menjadi psikiater. Karienya sebagai Guru Besar dalam Ilmu Kedokteran Forensik pada Universitas Torini setelah terbitnya buku yang judul (L'uomo Delinguate" atau “ the Criminal Man” (1876).

Dalam buku tersebut dijelaskan pendapatnya tentang asal atavisits dari “delinquent nato" atau "born criminal". Juga dikemukakan adanya hubungan yng erat antara kejahatan dengan epilepsy, kegilaandan degenerasi pada umumnya. Dengan perkataan lain, dalam buku tersebut Lombroso mengemukakan adanya tipe manusia yang lebih primitive dan lebih buas dari pada manusia lainnya (semasa) yang sudah beradab.

Kesimpulannya ialah: penjahat umumnya dipandang dari sudut anthropologi merupakan suatu jenis manusia tersendiri ('genus homo delinguens'), sperti halnya dengan bangsa negro. Mereka dilahirkan demikian, ('il delinguente nato'), mereka tidak mempunyai predisposisi untuk kejahatan, akan tetapi suatu predistinasi, dan tidak ada pengaruh lingkungan yang dapat merubahnya. Sifat batin sejak lahir ini juga dapat dikenal dari adanya stigmata-stigmata lahir. Jadi, terdapat suatu tipe penjahat yang dapat dikenal. ${ }^{57}$

Cesare Lombroso melakukan penyelidikan secara antropologi terhadap penjahat-penjahat yang terdapat dalam rumah penjara, terutama mengenai tengkoraknya. ${ }^{58}$ Kesimpulan dari penyelidikan itu adalah para penjahat dipandang dari sudut antropologi mempunyai tanda-tanda tertentu. Misalnya:59

a. Volume (isi) tengkoraknya kurang dari volume tengkorak orang lan umumnya.

b. Terdapat kelainan-kelainan pada tengkoraknya.

\footnotetext{
57 Ibid, hlm., 75.

58 Cesare Lombroso, dalam W.A.Bonger, Pengantar Tentang Kriminologi, PT. Pembangunan, Jakarta, 1995, hlm..80-83.

59 Ciri Nomor 11 s/d 13 dikutip dari Topo Santoso dan Eva Achjani Zulfa, Kriminologi, Raja Grafindo Persada, Jakarta,2006, hlm..38-39.
} 
c. Dalam otaknya terdapat keganjilan, seakan-akan mengingatkan pada otak hewan, biarpun tidak dapat ditunjukan adanya kelainan-kelaianan penjahat yang khusus.

d. Roman mukanya lain dari pada orang biasa, misalnya tulang dahi yang melengkung ke belakang (yang disebut front fuyant).

e. Perasaan kurang peka atau perasaanya tumpul.

f. Tahan sakit,

g. Suka akan tato, seperti halnya pada orang yang masih sederhana peradabannya.

h. Tengkorak yang miring dalain-lainnya.

i. Mata telinga yang tidak sama, dan umumnya segala asimetri.

j. Tumbuh rambut yang luar biasa.

k. Memiliki rahang yang besar.

1. Memiliki gigi taring yang kuat. Cirri fisik inibiasanya dimiliki oleh mahluk karnivora yang merobek dan melahap daging merah.

m. Jangkauan atau rentang lengan bawah dari para penjahat sering lebih besar di banding tinggi badan mereka. Ini dimiliki oleh kerah yang mengunakan tangan mereka untuk menggerakan tubuh mereka diatas tanah.

n. Bentuk tengkorak yang luar biasa, dengan keanehan-keanehan susuna otak sama dengan binatang wajah yang sangat buruk, rahang melebar, hidung yang miring, tulang dahi yang masuk melengkung masuk kebelakang.

\section{Aliran Neo Klasik}

Aliran neo klasik berkembang pada abad ke-19. Ia mempunyai basis pemikiran yang sama dengan aliran klasik, yakni kepercayaan kepada kebebasan berkehendak manusia. Dokrin dasarnya sama dengan aliran klasik, yakni bahwa manusia adalah mahluk yang mempunyai rasio, berkehendak bebas dan karenanya bertanggungjawab atas perbuatan-perbuatannya.

Meski demikian, terdapat sejumlah revisi yang dilakukan terhadap inti ajaran aliran klasik. Perubahan-perubahan tersebut antara lain: 
1. Perubahan pada dokrin kehendak bebas. Bagi aliran Neo Klasik, dalam melakukan sesuatu perbuatan jahat, pelaku tidak hanya ditentukan oleh factor free will semata, tetapi juga dipengaruhi oleh:

a. Petologi, ketidak mampuan untuk bertindak, sakit jiwa atau lain-lain keadaan yang mencegah seseorang untuk memperlakukan kehendak kebebasannya.

b. Premeditasi, niat yang dijadikan ukuran dari kebebasan kehendak, akan tetapi hal ini berkaitan dengan hal-hal yang aneh (irasional). Sebab, jika benar maka pelaku tindak pidana baru (untuk pertama kali) harus dianggap lebih bebas untuk memilih dari pada residivis yang terikat oleh kebiasaan-kebiasaannya, oleh karena itu, harus dihukum lebih besat untuk memilih dari pada residivis yang terikat oleh kebiasaankebiasannya, oleh karena itu harus dihukum lebih berat.

2. Pengakuan adanya keadaan-keadaan lingkungan atau keadaan mental dari individu. $^{60}$

3. Perubahan doktrin tanggung jawab sempurna yang mendasari ajaran pembalasan dalam aliran klasik. Bagi pemikir neo klasik, kesalahan tidak boleh ditimpakan sepenuhnya pada pelaku. Sebab, bisa saja seorang melakukan kejahatan karena faktor lain seperti kegilaan, kedunguan, usia dan lain-lain keadaan yang dapat mempengaruhi "pengetahuan dan niat" seseorang pada waktu melakukan kejahatan.

4. Dimasukkannya keterangan ahli dalam acara pengadilan untuk menentukan besar tanggungjawab, untuk menentukan apakah si terdakwa mampu memilih antara yang benar dan yang salah.

Ditinggalkannya penggunaan pemikiran yang hedonistis, dan kehendak bebas ini terpenuhi dengan lahirnya aliran positif, yang biasanya dihubungkan dengan nama Lombroso dan pengikut-pengikutnya di Italia. Mazhab positif ini lebih tepat digambarkan sebagai penambahan atau perluasan bagi kriminologi.

Bagi aliran neo klasik, reaksi penghukuman yang dihasilkan oleh aliran klasik terlalu berat dan merusak semangat kemanusiaan yang berkembang pada

\footnotetext{
${ }^{60}$ Indah Sri Utari, Op.cit, hlm., 82- 83.
} 
saat itu. Aliran sudah mempertimbangkan kebutuhan adanya pembinaan individual bagi pelaku tindak pidana.

\section{Aliran Kritis.}

Aliran kritis dikenal juga dengan istilah "Critical Criminology" atau "kiriminologi baru." Aliran kritis sesungguhnya memusatkan perhatian pada kritik terhadap intervensi kekuasaan dalam menentukan suatu perbuatan sebagai kejahatan. Itulah sebabnya, aliran ini menggungat eksitensi hukum pidana. Pendukung aliran ini menganggap bahwa pihak-pihak yang membuat hukum pidana hanyalah sekelompok kecil dari anggota masyarakat yang kebetulan memiliki kekuasaan untuk membuat dan membentuk hukum pidana tersebut. Jadi, hal yang dikatakan sebagai kejahatan dalam hukum pidana dapat saja dianggap oleh masyarakat (umum) sebagai hal yang bukan tidak kejahatan (tidak jahat). Dan tentunya, hal tersebut terjadi jika persepsi para pembuat hukum pidana berbeda dengan persepsi masyarakat luas pada umumnya. ${ }^{61}$

Pendekatan yang cukup dominan aliran kritis ini adalah pendekatan konflik. Pendekatan ini beranggapan hukum dibuat dengan ditegakkan bukan untuk melindungi masyarakat tetapi untuk melindungi nilai dan kepentingan kelompok yang berkuasa.

Dengan demikian, pendekatan konflik memusatkan perhatiannya pada masalah kekuasaan dalam pendefinisian kejahatan. Pendekatan konflik beranggapan bahwa orang-orang dalam suatu masyarakat mempunyai tingkat kekuasaan yang berbeda untuk mempengaruhi pembuatan dan penegakan hukum. pada umunya, orang-orang atau kelompok yang memiliki kekuasaan yang lebih besar akan mempunyai kesempatan dan kemampuan untuk menentukan perbuatan yang bertentangan dengan nilai dan kepentingan mereka sebagai kejahatan. Pada saat yang sama, mereka juga memiliki kemampuan untuk menghindari pendefinisian perbuatan mereka sebagai kejahatan, walaupun perbuatan mereka tersebut bertentangan dengan nilai dan kepentingan orang atau pihak lain yang tentunya memiliki kekuasaan yang lebih rendah.

\footnotetext{
${ }^{61}$ Indah Sri Utari, Ibid, Hlm., 84
} 
Pendekatan konflik dengan demikian mnghendaki suatu hukum yang bersifat emansipatif atau hukum yang melindungi masyarakat sehingga dapat mengangkat harkat dan martabat masyarakat kelas bawah.

Secara umum dapat dikatakan bahwa pendekatan konflik terdiri dari dua sub pendekatan (yang masing-masing berdiri sendiri) yaitu:

a. Pendekatan konflik yang Non-Marxis. Pendekatan ini menghendaki hukum (pidana) ditinjau kembali. Konsekuensi yang mungkin mengikuti keinginan peninjauan hukum (pidana) yang bersangkutan dapat saja diubah atau diganti dengan hukum (pidana) yang lebih baik.

b. Pendekatan konflik yang Marxis. Pendekatan ini mempersoalkan pihak yang membuat hukum (pidana). Tentu saja jawabannya adalah pemerintah. Kelompok atau pendukung pendekatan ini tidak percaya bahwa perubahan atau pergantian hukum (pidana) akan berhasil jika pembuatnya (pemerintah) tidak diganti juga. Alasannya adalah bahwa hukum (pidana) apapun yang dibuat akan tetap mewarnai nilai dan kepentingan penguasa. Oleh sebab itu, pendekatan konflik yang Marxis ini menghendaki perubahan structural. ${ }^{62}$

Jika ingin memakai mashab kritis ini, ada empat syarat dasar kajian yang harus diperhatikan:

a. Diperlukan suatu metologi yang dapat menggali kekayaan dunia penjahat serta metodologi yang dapat menghargai bermacam masalah yang dihadapi oleh penjahat.

b. Perhatian semua pihak hendaknya ditujukan pada dampak yang ditimbulkan lembaga-lembaga hukum terhadap realitas social penjahat.

c. Aspek criminal dan aspek noncriminal satu sama lain saling berhubungan erat.

d. Kejahatan dan penjahat adalah hasil interaksi antara aturan-aturan, pembentukan hukum, penegakan hukum dan pelanggaran hukum. dalam hal ini aturanlah yang memisahkan serta menentukan mana yang baik dan

\footnotetext{
62 Ibid, Hlm., 85
} 
mana yang buruh. Permasalahannya disini ialah apakah kriminalisasi yang terjadi itu tepat atau tidak. ${ }^{63}$

\section{Beberapa Teori dalam pemahaman tentang Kriminologi}

Teori dalam pemahaman Kriminologi tersebut adalah;

\section{Pengelompokan Teori;}

Dalam kepustakaan kriminologi, terdapat sejumlah pengelompokan teori, baik yang dilakukan oleh Frank P. Willims III dan Marilyn McShane maupun yang dilakukan oleh Hagan. ${ }^{64}$

Frank P. Williams III dan Marilyn McShane membagi teori kriminologi dalam tiga kelompok besar yaitu:

a. Teori-teori yang bersifat abstrack (macrotheories). Missal: Teori Anomi dan Teori Konflik.

b. Teori-teori yang bersifat lebih kongkrit (microtheories). Microtheories berusaha menjelaskan bagaimana seseorang menjadi criminal atau penjahat. Misal : Teori Social Control dan Teori Social Learning.

c. Bridging Theories, yakini teori-teori yang tidak termasuk dalam dua kelompok teori di atas. Misal: Teori Subkultur dan Differential Oppurtunity Theory.

Selain pengelompokan tersebut, Frank P. Williams III dan Marilyn McShane mengkasifikasi pula teori-teori kriminologi dalam tiga bagian yaitu:

1. Teori-teori klasik dan positif

Teori-Teori Klasik memfokus Pada:

- Legal Status

-

- Struktural yang sah

Sedangkan teori-teori positif lebih memfokus pada :

- Patologi criminal

- Pencegahan kejahatan

63 Ibid, Hlm., 86

${ }^{64}$ Ibid, Hlm., 88 
- Penanggulangan kejahatan.

2. Teori-teori struktur dan proses

Teori-teori structural memfokus pada "the way society is organized and its effect on behavior" (atau: struktur-struktur social dan efeknya terhadap tingkah laku individu). Sedangkan teori-teori yang memfokus pada proses, berusaha menjelaskan bagaimana seseorang menjadi penjahat.

3. Teori-teori konsensus dan konflik

Teori-teori consensus berdasar pada asumsi bahwa dalam masyarakat terdapat konsesus atau pertujuan, misalnya nilai-nilai yang bersifat umum, yang telah disepakati bersama. Sedangkan teori-teorikonflik berasumsi bahwa dalam masyarakat terdapat sedikit konsesnsus dan lebih banyak memancing konflik. ${ }^{65}$

Selain itu, sebagai perbandingan John Hagan mengklasifikasikan teori-teori kriminologi menjadi:

seperti teori Disorganisasi Sosial, teori Netralisasi dan teori Kontrol Sosial. Pada asasnya, teori-teori ini membahas mengapa ada orang melanggar hukum sedangkan kebanyakan orang tidak demikian.

- Teori-teori Kultur, Status dan Opportunity seperti teori Status Frustasi, teori Kultur Kelas dan teori Oppurtunity yang menekankan mengapa adanya sebagian kecil orang menentang aturan yang telah ditetapkan masyarakat dimana mereka tinggal/hidup.

Kelompok dan teori Marxis. Teori-teori ini lebih meneknkan pada masalah mengapa orang bereaksi terhadap kejahatan.

Selanjutnya, pada tahun 1947 Edwin H. Sutherland menyajikan versi kedua dari teori Differential Association yang menekankan bahwa semua tingkah laku itu dipelajari, tidak ada yang diturunkan berdasarkan pewarisan orang tua. Tergasnya, pola perilaku jahat tidak diwariskan tapi dipelajari melalui suatu pergaulan yang

\footnotetext{
${ }^{65}$ Ibid, Hlm., 89.
} 
akrab. Untuk iru, Edwin H.Sutherland kemudia menjelaskan 9 jalan proses terjadinya kejahatan:

1. Tingkah laku jahat itu dipelajari. Sutherland menyatakan bahwa tingkah laku itu tidak diwarisi sehingga tidak mungkin ada orang jahat secara mekanis;

2. Tingkah laku jahat itu dipelajari dari orang-orang lain dalam suatu proses interaksi;

3. Bagian yang terpenting dari tingkah laku jahat yang dipelajari, diperoleh dalam kelomok pergaulan yang akrab; Dengan demikian, komunikasi interpersonal yang sifatnya sesaat dan insedental, tidak mempunyai peranan penting dalam proses pembelajaran kejahatan tersebut. ${ }^{66}$

4. Ketika perilaku kejahat itu dipelajari, maka yang dipelajari adalah (a) cara melakukan kejahatan itu baik yang sulit maupun yang sederhana, (b) bimbingan yang bersifat khusus mengenai motif, rasionalisasi, serangan, dan sikap;

5. Bimbingan yang bersifat khusus mengenai motif dan serangan itu dipelajari dari penafsiran terhadap undang-undang; Dalam suatu masyarakat, kadang seseorang dikelilingi orang-orang yang secara bersamaan melihat apa yang diatur dalam peraturan hukum sebagai sesuatu yang perlu diperhatikan dan dipatuhi, namun kadang ia dikelilingi orang-orang yang melihat aturan hukum sebagai seuatu yang memberikan peluang dilakukannya kejahatan.

6. Seseorang menjadi delinkuen karena ekses pola-pola piker yang lebih melihar aturan hukum sebagai pemberi peluang melakukan kejahatan dari pada melihat hukum sebagai sesuatu yang harus diperhatikan.

7. Asosiasi Diferensial bervariasi dalam frekuensi, durasi, prioritas serta intensitasnya.

8. Proses mempelajari perilaku jahat diperoleh melalui hubungan dengan pola-pola kejahatan dan mekanisme yang lazim terjadi dalam setiap proses belajar secara umum.

\footnotetext{
66 Ibid, Hlm., 91-92.
} 
9. Sekalipun perilaku jahat merupakan pencerminan dari kebutuhan umum dan nilai-nilai, namun tingkah laku criminal tersebut tidak dijelaskan melalui kebutuhan umum dan nilai-nilai dimaksud, sebab tingkah lau non criminal pun merupakan pencerminan dari kebutuhan umum dan nilainilai yang sama. ${ }^{67}$

Penulis dalam buku" Penghukuman Tanpa Hakim" ini tidak terlupan dengan menggunakan "Teori Kontrol” teoril untuk ini digunaka oleh penulis untuk mencari jawaban dalam suatu adanya peristiwa tindak pidana.

Teori konrol berusaha untuk menjelas kenakalan di kalangan para remaja. Kenakalan di antara para remaja, oleh Steven Box dikatakan sebagai deviasi primer. Yang dimaksud dengan deviasi primer adalah setiap individu yang:

1. Melakukan deviasi secara periodic/jarang-jarang,

2. Dilakukan tanpa diorganisir atau tanpa menggunakan cara yang lihai,

3. Si pelaku tidak memandang dirinya sebagai pelanggar,

4. Pada dasarnya hal yang dilakukan itu tidak dipandang sebagai deviasi oleh yang berwajib

Para teoritikus teori control memandang bahwa manusia merupakan makhluk yang memiliki moral yang murni. Olah karena itu, setiap individu bebas untuk berbuat sesuatu. Kebebasa ini akan membawa seseorang pada tindakan yang bermacam-macam. Tindakan ini lazimnya didasarkan pada pilihan: taat pada hukum, atau melanggar aturan-aturan hukum. sedangkan tindakan yang dipilih didasarkan pada ikatan-ikatan social yang terlah terbentuk.

Kemunculan teori control disebabkan tiga ragam perkembangan dalam kriminologi. Pertama, adanya reaksi terhadap orientasi labeling dan konflik yang kembali menyelidiki tingkah laku criminal. Kriminologi konservartif (sebagaimana teori ini berpijak) kurang menyukai "kriminologi baru" atau "new criminology" dan hendak kembali kepada subyek semula, yaitu penjahat (criminal).

Kedua, munculnya studi tentang "criminal justice" dimana sebagai suatu ilmu baru telah mempengaruhi kriminologi menjadi lebih pragmatis dan berorientasi pada system. Ketiga, teori kontol social telah dikaitkan dengan suatu

\footnotetext{
67 Ibid, Hlm., 92-93.
} 
teknik penelitian baru, khususnya bagi tingkah laku anak/remaja, yakni selfreport survey.

Pada tahun 1951, Albert J. Reiss, Jr menggabungkan konsep kepribadian dan sosialisasi dengan hasil penelitian dari aliran Chicagi dan menghasilkan teori control social. Menurut Reiss, terdapat tiga komponen control social dalam menjelaskan kenakalan remaja, yaitu: ${ }^{68}$

1. A lack of proper internal controls developed during childhood

2. A breakdown of those internal controls

3. An absence of or conflict in social rules provided by important social group (the family, close other, the school)

Selanjutnya, Reiss, Jr membedakan dua macam control, yaitu personal control dan social control. Personal control adalah kemampuan seseorang untuk menahan diri agar tidak mencapai kebutuhannya dengan cara melanggar normanorma yang berlaku di masyarakat. Sedangkan social control adalah kemampuan kelompok social atau lembaga-lembaga dimasyarakat melaksanakan norma-norma atau peraturan-peraturan menjadi efektif.

Pada tahun 1957, Jackson Toby memperkenalkan pengertian "Commitment" individu sebagai kekuatan yang sangat menentukan dalam membentuk sikap kontol social. Kemudian, Scot Briar dan Irvine Piliavian menyatakan bahwa peningkatan koitmen individu dan adaptasi/penyesuaian diri memegang peranan dalam mengurangi penyimpangan.

Pendekatan lain digunakan Walter Reckless (1961) dengan bantuan rekannya Simon Dinitz. Walter Walter Reckless menyampaikan Contaiment Theory yang menjelaskan bahwa kenakalan remaja merupakan hasil (akibat) dari interelasi antara dua bentuk control, yaitu internal (inner) dan eksternal (outer). Menurut Walter Recklees, containment internal dan eksternal memiliki posisi netral, berada dalam tarikan social (social pull) lingkungan dan dorongan dari dalam individu.

F. Ivan Nye dalam tulisannya yang berjudul Family Relationsip and Deliquent Behavior (1958), mengemukakan teori kontol tidak sebagai suatu penjelasan umum tentang kejahatan melainkan penjelasan yang bersifat kasuistis.F.

${ }^{68}$ Ibid, Hlm., 125-127. 
Ivan Nye pada hakikatnya tidak menolak adanya unsur-unsur psikologis, di samping unsur subkultur dalam proses terjadinya kejahatan. Sebagian kasus delinkuen, menurut . Ivan Nye disebabkan gabungan antara hasil proses belajar dan control social yang tidak efektif. ${ }^{69}$

Karena itu, bagi Ivan Nye, kontribusi keluarga pada terjadinya kejahatan atau delinkuen adalah sangat besar, karena keluarga merupakan tempat terjadinya pembentukan kepribadian, internalisasi, orang belajar baik dan buruk dari keluarga. Jika control internal dan eksternal lemah, maka terjadilah delinkuen. Menurut F. Ivan Nye manusia diberi kendali supaya tidak melakukan pelanggaran, karena itu proses sosialosasi yang adequate (memadai) akan mengurangi terjadinya delinkuensi. Sebab, di sinilah dilakukan proses pendidikan terhadap seseorang yang diajari untuk melakukan pengekangan keinginan (impulse). Di samping itu, factor internal dan eksternal control harus kuat, juga dengan ketaan terhadap hukum (lawabiding).

Jelas kiranya, ada beberapa poin penting dalam teori control versi Ivan Nye:

a. Harus ada control internal maupun eksternal

b. Manusia diberikan kaidah-kaidah supaya tidak melakukan pelanggaran;

c. Pentingnya proses sosialisasi bahwa ada sosialisasi yang adequate (memadai), akan mengurangi terjadinya delinkuen, karena di situlah dilakukan proses pendidikan terhadap seseorang;dan

d. Diharapkan remaja mentaati hukum (law abiding).

Menurut Ivan Nye terdapat empat tipe control social, yaitu :

a. Direct control imposed from without by means of restriction and punishment

b. Internalized control exercised from withim through conscience;

c. Indirect control related to affectional indentification with parent and other non-criminal persons; and

d. Availability of alternative to goal dan values.

${ }^{69}$ Ibid, hlm., 127-128. 
Konsep control eksternal menjadi dominan setelah David Matza dan Gresham Sykes melakukan kritik terhadap teori subkultur dari Albert Cohen. Kritik tersebut menegaskan bahwa sekalipun kenakalan remaja dilakukan oleh mereka yang berasal dari strata social rendah, namun tetap saja terikat pada system-sistem nilai dominan di dalam masyarakat.

Kemudian, David Matza dan Gresham Sykes mengemukakan konsep atau teori yang dikenal dengan technique of neutralization, yaitu suatu teknik yang memberikan ksempatan bagi seorang individu untuk melonggarkan keterikatannya dengan system nilai-nilai yang dominan sehingga bebas untuk melakukan kenakalan. Teknik netralisasi ini dirinci David Matza dan Gresham Sykes, sebagai berikut: ${ }^{70}$

1. Teknik yang disebut denial of responsibility, menunjuk pada suatu anggapan dikalangan remaja nakal yang menyatakan bahwa dirinya merupakan korban dari orang tua yang tidak kasih, lingkungan pergaulan yang buruk atau berasal dari tempat tinggal kumuh (slum).

2. Teknik denial of injury, menunjuk kepada suatu alasan di kalangan remaja nakal bahwa tingkah laku mereka sesungguhnya tidak merupakan suatu bahaya yang besar/berarti. Sehingga, mereka beranggapan bahwa vandalism merupakan kelalaian semata-mata dan mencuri mobil sesungguhnya meminjam mobil, perkelahian antara gang merupakan pertenkaran biasa.

3. Teknik denial of the victim, menunjuk kepada suatu keyakinan diri pada remaja nakal bahwa mereka adalah pahlawan sedangkan korban justru dipandang sebagai mereka yang melakukan kejahatan.

4. Teknik yang disebut condemnation of the comdemmers, menunjuk kepada suatu anggapan bahwa polisi sebagai hipokrit, munafik atau pelaku kejahatan terselubung yang melakukan kesalahan atau memiliki perasaan tidak senang pada mereka. Pengaruh teknik ini adalah mengubah subyek yang menjadi pusat perhatian, berpaling dari perbuatan-perbuatan kejahatan yang telah dilakukannya.

${ }^{70}$ Ibid, hlm., 129. 
5. Teknik appeal to higher loyalties, menunjuk pada suatu anggapan di kalangan remaja nakal bahwa mereka tertangkap di antara tuntutan masyarakat, hukum dan kehendak kelompok mereka.

Lima teknik netralisasi di atas menurut David Matza (1964), yang kemudian ditegaskan sebagai penyimpangan atas apa yang disebut sebagai bond to moral order, mengakibatkan seseorang terjerumus dalam keadaan dimana kenakalan remaja atau penyimpagan tingkah laku sebagai sesuatu yang diperbolehkan. ${ }^{71}$

Versi teori social yang paling handal dan sangat popular dikemukakan Travis Hirschi (1969). Hirschy, dengan keahlian merevisi teori-teori sebelumnya tentang control social, telah memberikan suatu gambaran jelas mengenai konsep social bond, Travis Hirschi sependapat dengan Durkheim dan yakin bahwa tingkah laku seseorang mencerminkan pelbagai ragam pandangan tentang kesusilaan/morality.

Hirschi berpendapat bahwa seseorang bebas untuk melakukan kejhatan atau penyimpangan tingkah lakunya. Selain menggunakan teknik netralisasi untuk menjelaskan tingkah laku dimaksud, Hirschi juga menegaskan bahwa tingkah laku tersebut diakibatkan oleh tidak adanya keterikatan atau kurangnya keterikatan (moral) pelaku terhadap masyarakat.

Teori Kontrol atau sering juga disebut dengan Teori Kontrol Sosial berangkat dari suatu asumsi atau anggapan bahwa individu di masyarakat mempunyai kecenderungan yang sama kemungkinannya, menjadi "baik" atau "jahat"/ baik jahatnya seseorang sepenuhnya tergantung pada masyarakatnya. Ia menjadi baik kalau masyarakatnya membuatnya demikian, pun ia menjadi jahat apabila masyarakat membuatnya begitu.

Pertanyaan dasar yang dilontarkan paham ini berkaitan dengan unsur-unsur pencegah yang mampu menangkal timbulnya perilaku delinkuen di kalangan anggota masyarakat, utamanya para remaja, "mengapa kita patuh dan taat pada norma-norma masyarakat" atau "mengapa kita tidak melakukan penyimpangan?"72

Menurut Travis Hirschi, terdapat empat elemen ikatan social (social bond) dalam setiap masyarakat. Pertama, attachment adalah kemampuan manusia untuk melibatkan dirinya terhadap orang lain. Kalau attachment ini sudah terbentuk,

${ }^{71}$ Ibid, Hlm., $130-131$.

72 Ibid, Hlm., 131-132. 
maka orang tersebut akan peka terhadap pikiran, perasaan dan kehendak orang lain. Kaitan attachment dengan penyimpangan adalah sejauh mana orang tersebut peka terhadap pikiran, perasaan dan kehendak orang lain sehingga ia dapat dengan bebas melakukan penyimpangan. Attachment seirng diartikan secara bebas dengan keterikatan. Ikatan pertama yaitu keterikatan dengan orang tua, keterikatan dengan sekolah (guru) dan keterikatan dengan teman sebaya.

Kedua, commitment adalah keterikatan seseorng pada subsistem konvensional seperti sekolah, pekerjaan, organisasi dan sebagainya. Komitmen merupakan aspek rasional yang ada dalam ikatan social. Segala kegiatan yang dilakukan seseorang seperti sekolah, pekerjaan, kegiatan dalam organisasi akan mendatangkan manfaat bagi orang tersebut. manfaat tersebut dapat berupa harta benda, reputasi, masa depan, dan sebagainya.

Ketiga, involvement merupakan aktivitas seseorang dalam subsistem. Jika seseorang berperan aktif dalam organisasi masa kecil kecenderungannya untuk melakukan penyimpangan. Logika pengertian ini adalah bila orang aktif di segala kegiatan maka ia akan menghabiskan waktu dan tenaganya dalam kegiatan tersebut. sehingga, ia tidak sempat lagi memikirkan hal-hal yang bertentangan dengan hukum. dengan demikian, segala aktivitas yang dapat member manfaat akan mencegah orang itu melakukan perbuatan yang bertentangan dengan hukum.

Keempat, belief merupakan aspek moral yang terdapat dalam ikatan social dan tentunya berbeda dengan ketiga aspek diatas. Belief merupakan kepercayaan seseorang pada nilai-nilai moral yang ada. Kepercayaan seseorang terhadap normanorma yang ada menimbulkan kepatuhan terhadap norma tersebut. kepatuhan terhadap norma tersebut tentunya akan mengurangi hasrat untuk melanggar. Tetapi, bila orang tidak meatuhi norma-norma maka lebih besar kemungkinan melakukan pelanggaran. ${ }^{73}$

Hubungan antara Attachment dan Commitment seringkali dinyatakan cenderung berubah-ubah secara terbalik. Menurut riset tentang delinkuen, salah satu "masalah" anak remaja dari kelas bawah adalah bahwa dia tidak mampu memutuskan keterikatan dengan orang tua dan kawan sebaya. Keterikatan yang

${ }^{73}$ Ibid, Hlm., 133 
mencegahnya mencurahkan waktu dan energy yang cukup bagi aspirasi pndidikan dan pekerjaan.

Menurut riset stratifikasi, anak lelaki yang terbebas dari keterikatan ini lebih memungkinkan untuk berpindah-pindah ke kelas atas. Kedua tradisi riset demikian menyatakan bahwa orang-orang yang terikat pada confotmity (persesuaian)karena alasan-alasan instrumental kurang mungkin untuk terikat persesuaian berdasarkan alasan emosional yang lainnya. Apabila mreka yang tidak terikat dikompensasikan atas kekurangan keterikatan berdasarkan komitmen untuk berprestasi dan apabila tidak melakukannya berubah menjadi terikat dengan orang-orang, kita bisa menyimpulkan bahwa baik attachment maupun commitment tidakakan dihubungkan dengan kejahatan.

Pertautan paling jelas antara unsure/elemen commitment dan involvement Nampak dalam komitmen di bidang pendidikan dan pekerjaan serta keterlibatan dalam aktivitas-aktivitas konvensional. Kita dapat berusaha memperlihatkan bagaimana komitmen membatasi kesempatan seseorang untuk melakukan kejahatan dan dengan demikian dijauhkan dari anggapan (asumsi) banyak teori control bahwa kesempatan-kesempatan seperti itu secara sederhana dan acak disebarkan melalui populasi yang diperlukan.

Hubungan elemen terakhir dari teori control social adalah antara Attcahment dan Belief, bahw terdapat hubungan yang kurang lebih berbanding lurus antara keterikatan dengan yang lainnya dan kepercayaan dalam keasahan moral dari peraturan yang ada.

Teori control mempunyai sejumlah kelemahan maupun kelebihan. Adapun kelemahannya berorientasi pada: ${ }^{74}$

1. Teori ini berusaha menjelaskan kenakalan remaja dan bukan kejahatan oleh orang dewasa;

2. Teori ini menaruh perhatian cukup besar pada sikap, keinginan dan tingkah laku yang meski menyimpang sering merupakan tingkah laku orang dewasa;

\footnotetext{
${ }^{74}$ Ibid, Hlm., 134
} 
3. Ikatan social (social bond) dalam teori Hirschi seperti values, belief, norma dan attitude tidak pernah secara jelas didefinisikan;

4. Kegagalan dalam menjelaskan peluang kejadian yang menghasilkan lebih tidaknya social bond.

\section{UNDERSTANDING AND ELEMENTS OF THE TRADE (PENGERTIAN DAN UNSUR-UNSUR PERDAGANGAN ORANG)}

Sebelum Undang-Undang Tindak Pidana disahkan beberapa waktu yang lalu, pengertian tindak pidana perdagangan orang yang umum paling banyak digunakan adalah pengertian dari Protokol PBB untuk mencegah, menekan dan menghukum pelaku perdagangan orang. Dalam protocol PBB tersebut pengertian pedagangan orang adalah: ${ }^{75}$

a. Perekrutan, pengiriman, pemindahan, penampungan atau penerimaan seseorang, dengan ancaman atau penggunaan kekerasan atau bentukbentuk lain dari pemaksaan, penculikan, penipuan, kobohongan atau penyalahgunaan kekuasaan atau posisi rentan atau member atau menerima pembayaran atau memperoleh keuntungan agar dapat memperoleh persetujuan dari seseorang yang berkuasa atas orang lain, untuk tujuan ekspoitasi. Eksploitasi termasuk, paling tidak, eksploitasi untuk melacurkan orang lain atau bentuk-bentuk lain dari eksploitasi seksual, kerja atau pelayanan paksa, perbudakan atau praktik-praktik serupa perbudakan, penghambaan atau pengambilan organ tubuh.

b. Persetujuan korban perdagangan orang terhadap eksploitasi yang dimaksud yang dikemukakan dalam sub-alinea (a) ini tidak relavan jika salah satu dari cara-cara yang dimuat dalam sub_alinea (a) digunakan.

c. Perekrutan, pengiriman, pemindahan, penampungan atau penerimaan seorang anak untuk tujuan eksploitasi dipandang sebagai perdagangan orang bahkan jika kegiatan ini tidak melibatkan satu pun cara yang dikemukakan dalam subalinea (a) pasal ini.

\footnotetext{
${ }^{75}$ Farhana, Aspek Hukum Perdagangan Orang di Indonesia, Penerbit Sinar Grafika, Jakarta, 2010, hlm. 20
} 
d. Anak adalah setiap orang yang berumur di bawah 18 tahun. $^{76}$

Pengertian di atas tidak menekankan pada perekrutan dan pengiriman yang menentukan suatu perbuatan tersebut adalah tindk pidana perdagangan orang, tetapi juga kondisi eksploitatif terkait ke dalam mana orang diperdagangkan. Dari pengertian tersebut ada tiga unsure yang berbeda yang saling berkaitan satu sama lainnya, yaitu:

a. Tindakan atau perbuatan yang dilakukan, yaitu perekrutan, pengiriman, pemindahan, penampungan atau penerimaan seseorang;

b. Cara, menggunakan ancaman atau penggunaan kekerasan, atau bentukbentuk paksaan lain, penculikan, tipu daya, penipuan, penyalahgunaan kekuasaan atau kedudukan rentan atau pemberian atau penerimaan pembayaran atau keuntungan untuk memperoleh persetujuan dari orangorang;

c. Tujuan atau maksud, untuk tujuan eksploitasi. Eksploitasi mencakup setidak-tidaknya eksploitasi pelacuran dari orang lain atau bentuk-bentuk eksploitasi seksual lainnya, kerja paksa, perbudakan, penghambaan dan pengambilan organ tubuh.

Untuk lebih jelasnya, dapat dilihat pada table 1.1. jika salah satu factor dari ketiga unsur di atas terpenuhi, maka terjadilah perbuatan perdagangan orang. ${ }^{77}$ Persetujuan dari korban berkenaan dengan eksploitasi yang menjadi tujuan dari perdagangan orang tersebut kehilangan relevansinya atau tidak lagi berarti, bilamana cara-cara pemaksaan atu penipuan sebagaimana diuraikan dalam pengertian di atas telah digunakan.

Tabel Kerangka Korban Perdagangan Orang

\begin{tabular}{|c|c|c|c|c|}
\hline Proses/Cara & + & Jalan/Cara & + & Tujuan \\
\hline Perekrutan & & Ancaman & & Prostitusi \\
\hline Atau & & Atau & & Atau \\
\hline Pengiriman & D & Pemaksaan & D & Pornografi \\
\hline Atau & & Atau & & Atau \\
\hline Pemindahan & A & Penculikan & A & $\begin{array}{c}\text { Kekerasan/Eksploitasi } \\
\text { Seksual }\end{array}$ \\
\hline
\end{tabular}

${ }^{76}$ Ruth Rosenberg, Perdagangan Perempuan dan Anak Indonesia, Jakarta:USAID, Tahun 2003, hlm.. 287

77 Lihat Pasal 3 (b) Protokol PBB. 


\begin{tabular}{|c|c|c|c|c|} 
Atau & & Atau & & Atau \\
\hline Penampungan & $\mathrm{N}$ & Penipuan & $\mathrm{N}$ & Kerja Paksa \\
\hline Atau & & Atau & & Atau \\
\hline Penerimaan & & Kebohongan & & $\begin{array}{c}\text { Perbudakan/Praktik } \\
\text { Serupa }\end{array}$ \\
\hline & & Atau & & Atau \\
\hline & & $\begin{array}{c}\text { Penyalahgunaan } \\
\text { Kekuasaan }\end{array}$ & & $\begin{array}{c}\text { Pengambilan } \\
\text { OrganTubuh }\end{array}$ \\
\hline
\end{tabular}

Sumber: Perdagangan Perempuan dan Anak Indonesia, Ruth Rosenberg, 2003, hlm.16

Setiap tindakan rekrutmen, pengiriman, pemindahan, penempatan, atau penerimaan seorang anak dengan maksud eksploitasi, dianggap sebagai perdagangan orang walaupun cara-cara pemaksaan atau penipuan dalam pengertian di atas tidak digunakan. ${ }^{78} \mathrm{Hal}$ ini ditegaskan bahwa untuk korban perdagangan anak, tanpa terpenuhinya unsure kedua, yaitu menggunakan cara ancaman atau penggunaan kekerasan atau bentuk-bentuk pemaksaan lain, penculikan, tipu daya, penipuan, penyalahgunaan kekuasaan, atau kedudukan rentan atau pemberian atau penerimaan pembayaran atau keuntungan untuk memperoleh persetujuan dari orang-orang sudah merupakan bentuk perdagangan orang.

Digunakannya cara tipu daya, penipuan penyalahgunaan kekuasaan atau kedudukan rentan menunjukan bahwa perdagangan orang dapat terjadi tanpa adanya kekerasan secara fisik. Adapun penyalahgunaan akan kedudukan rentan (abuse of position of vulnerability) diartikan sebagai sebuah situasi di mana seseorang tidak memiliki pilihan atau yang dapat diterima, kecuali untuk pasrah pada penyalahgunaan yang terjadi. Cara-cara tersebut dilakukan mengakibatkan terdistorsinya kehendak bebas seseorang. Tipu daya dan penipuan berkenaan dengan apa yang dijanjikan dan realisasinya, yaitu mencakup jenis pekerjaan dan kondisi kerja. ${ }^{79}$

Menurut protocol PBB menetapkan bahwa persetujuan korban menjadi tidak relavan atau dapat diabaikan jika cara-cara yang disebutkan dalam protocol tersebut telah digunakan. Hal ini sejalan dengan norma hukum internasional yang berlaku

\footnotetext{
78 Farhana, op., cit. hlm. 22

79 Supriyadi Widodo Eddyono, Perdagangan Manusia dalam Rancangan KUHP, cet.1, Jakarta: ELSAM, tahun 2005, hlm. 8 .
} 
dan tidak meniadakan hak terdakwa untuk membela diri sepenuhnya dan juga tidak mengesampingkan berlakunya asas perduga tak bersalah. Ketentuan dan penjelasan di atas tidak boleh dimengerti sebagai beban korban untuk membuktikan atau hilangnya persetujuan. ${ }^{80}$

Dalam proses pengadilan pidana nasional bahwa beban pembuktian merupakan tugas Negara atau jaksa penuntut umum, tetapi ketika unsur-unsur tindak pidana perdagangan orang telah dibuktikan, pernyataan atau keterangan bahwa korban memberikan persetujuan menjadi tiadk relavan. Di dalam praktiknya, sering terjadi persetujuan menimbulkan kebingungan dan keracuan, karena apabila seorang tampaknya telah memberikan persetujuanhnya terhadap apa yang dalam kenyataan merupakan kerja paksa atau praktik perbudakan, maka muncul argumen bahwa orang tersebut telah mengalami perdagangan. Untuk menilai keaslian persetujuan tersebut yang diberikan harus dipertimbangkan sejumlah faktor, sehingga persetujuaan yang didapat apakah benar-benar ada atau hanya seolah-olah saja.

Selain unsure perbuatan dan cara dari perdagangan manusia, ada juga unsurtujuan dilakukannya perbuatan tersebut, yaitu untuk eksploitasi dan bentukbentuk eksploitasi lainnya. Dalam protocol PBB, pengertian eksploitasi dan bentuk-bentuk eksploitasi tidak didefinisikan lebih lanjut. Istilah atas kegiatan prostitusi dan eksploitasi seksual merupakan satu-satunya bentuk dari definisi perdagangan orang yang dibiarkan tidak didefinisikan dimanapun dalam hukum internasional. $^{81}$

Eksploitasi merupakan kegiatan yang bersifat perbudakan, pekerjaan dengan kekerasan atau pemaksaan dan kerja paksa, sedangkan eksplotasi seksual yang berkaitan dengan prostitusi baik secara sukarela maupundipaksi, ditiap Negara mempunyai kebijakan berbeda-beda, sehingga memberikan keleluasaan bagi Negara-negara untuk mengatur lebih lanjut masalah prostitusi di dalam hukum nasional masing-masing. Walaupun tiap-tiap Negara memiliki definisi yang berbeda tentang pekerja seks dewasa sukarela dan mengandung aturan yang mengikat yang dapat menghukum pelaku jika terjadi pelanggaran. Unsurpaksaan

\footnotetext{
${ }^{80}$ Ibid, hlm.. 9.

${ }^{81}$ Ibid.,hlm.. 10.
} 
dalam prostitusi merupakan unsure penentu terjadinya perbuatan perdagangan orang.

Dengan demikian, pengertian eksploitasi seksual adalah mereka yang terlibat dalam prostitusi, pelayanan atau pejerka seks atau menjadi objek kegiatan pornografi yang dikarenakan oleh ancaman pemaksaan, penculikan diperlakukan dengan salah, menjadi orang yang dijual atau karena korban penipuan. Adapaun eksploitasi dengan melacurkan orang lain adalah kegiatan untuk memperoleh uang dan keuntungan lain dari kegiatan melacurkan orang lain dalam kegiatan prostitusi atau secara seksual. ${ }^{82}$ Adapaun eksploitasi lainnya berupa kerja paksa perbudakan, penghambaan, atau penjualan organ tubuh pengertiannya terdapat dalam insrumeninstrumen hukum internasional lainnya. Sperti kerja paksa terdapat dalam Konvensi ILO Nomor 29 tentang Kerja Paksa dan Konvensi Nomor 105 tentang Penghapusan Kerja Paksa.

Pengertian perdagangan orang dari pengambilan organ-organ tubuh hanya ada jika seseorang dipindahkan untuk tujuan pemindahan organ dan protocol PBB ini tidak mengatur jika hanya berupa pemindahan organ (organ yang dipindahkan sudah tidak berada dalam tubuh lagi) ${ }^{83}$

Sebelum pemerintah Indonesia merumuskan suatu definisi perdagangan orang secara resmi yang disesuaikan dengan situasi yang dihadapi Indonesia, digunakan dalam perumusan Rncana Aksi Nasional (RAN) untuk Penghapusan Perdagangan Perempuan dan Anak, pemerintah menggunakan definisi protocol PBB. Tetapi perumusan dalam RAN dan Protokol PBB ini tidak cukup kuat untuk mempengaruhi system peradilan Indonesia. Polisi, Jaksa, dan Pengacara lebih banyak mempergunakan perangkat hukum, yaitu KUHP dalam proses persidangan. Pengadilan menjadi tidak cukup tajam dalam memahami persoalan perdagangan orang. Akibatnya, putusan-putusan yang dihasilkan menjadi tidak tegas dalam menindak pelaku perdagangan orang. Sekarang sudah disahkan Undang-Undang Nomor 21 Tahun 2007 tentang Tindak Pidana Perdagangan Orang dimana definisi atau rumusan perdagangan orang terdapat dalam undang-undang tersebut.

\footnotetext{
${ }^{82}$ Ibid.,hlm.. 11

83 Ibid.,hlm..13.
} 


\section{Pengertian Perdagangan Orang Menurut Undang-Undang Nomor 21 Tahun}

\section{7 tentang Pemberantasan Tindak Pidana Perdagangan Orang}

Dalam Undang-undang Nomor 21 Tahun 2007 tentang Pemberantasan Tindak Pidana Perdagangan Orang dan tidak jauh berbeda dengan rumusan dari protocol PBB dan lebih rinci atau mencakup ruang lingkup tindak pidana perdagangan orang dari rumusan KUHP. Dalam Pasal 1 ayat (1) menyatakan bahwa perdagangan orang adalah sebagai berikut.

“Tindakan perekrutan,pengangkutan,penampungan,pengiriman,pemindahan, atau penerimaan seseorang dengan ancaman kekerasan, penggunaan kekerasan, penculikan, penyekapan, pemalsuan, penipuan, penyalahgunaan kekuasaan atau posisi rentan, penjeratan utang atau member bayaran atau manfaat, sehingga memperoleh persetujuaan dari orang yang memegang kendali atas orang lain tersebut, baik yang dilakukan di dalam Negara maupun anternegara, untuk tujuan mengeksploitasi atau mengakibatkan orang tereksploitasi." 84

("The action of recruitment, transportation, harboring, transportation, transfer, or receipt of persons by threat of violence, the use of violence, abduction, confinement, forgery, fraud, abuse of power or of a position of vulnerability, debt bondage or members payment or benefits to achieve the persetujuaan of people who having control over another person, whether conducted in the State and anternegara, for the purpose of exploiting or cause people to be exploited. ")

Dalam Undang-Undang Nomor 21 Tahun 2007 tentang Pemberantasan

Tindak Pidana Perdagangan Orang, eksploitasi dijelaskan dalam Pasal 1 ayat (7)

yang menyebutkan bahwa:

“eksploitasi adalah tindakan dengan atau tanpa persetujuan korban yang meliputi, tetapi tidak terbatas pada pelacuran, kerja atau pelayanan paksa, perbudakan atau praktik serupa perbudakan, penindasan, pemerasan pemanfaatan fsik, seksual, organ reproduksi atau secara melawan hukum memindahkan atau mentransplantasi organ dan/atau jaringan tubuh, atau memanfaatkan tenaga atau kemamopuan seseorang oleh pihak lain untuk mendapatjan keuntungan baik materiil maupun immaterial"

("Exploitation is action with or without the victim's consent, including, but not limited to prostitution, forced labor or services, slavery or practices similar to slavery, oppression, extortion fsik utilization, sexual, reproductive organs or unlawfully removing or transplanting organs and / or tissue, or

\footnotetext{
${ }^{84}$ Farhana, op. cit.,,hlm. 25.
} 
take advantage of someone by force or kemamopuan others to profit mendapatjan material and immaterial ")

Unsur tujuan untuk mengeksploitasi atau mengakibatkan orang tereksploitasi ini tidak relavan lagi atau tidak berate apabila cara-cara pemaksaan atau penipuaan sebagaimana diuraikan dalam definisi di atas digunakan. Dalam undang-undang Nomor 21 Tahun 2007 tentang Pemberantasan Tindak Pidana Perdagangan orang ditegaskan dalamPasal 1 ayat (7), dengan menyebutkan bahwa "Eksploitasi adalah tindakan dengan atau tanpa persetujuan korban...." Ditegaskannya persetujuan korban sebagai hal yang tidak relavan atau tidak berarti lagi, jika unsure cara-cara yang disebutkan dalam rumusan di atas digunakan,sangat penting disebutkan dalam peraturan tentang perdagangan orang karena dapat melemahkan niat untuk menghukum pelaku perdagangan orang. Sering terjadi dalam kasus bahwa argumentasi pelaku selalu menggunakan alasan bahwa korban telah setuju atau adanya persetujuan dari korban atau korban mau dan sepakat untuk ikut. Oleh karena itu, dipertegas dalam Pasal 26 Undang-Undang Nomor 21 Tahun 2007 tentang Tindak Pidana Perdagangan Orang bahwa persetujuan korban tidak menghilangkan penuntutan tindak pidana perdagangan orang. Unsure tujuan ini juga menunjukan bahwa tindak pidana perdagangan orang merupakan tindak pidana formil, yaitu adanya tindak pidana perdaganngan orang cukup dengan dipenuhinya unsur-unsur tindak pidana yang sudah dirumuskan dan tidak harus menimbulkan akibat.

Dalam Undang-Undang Nomor 21 Tahun 2007 tentang Pemberantasan Tindak Pidana Perdagangan Orang, pengertian perekrutan dan pengiriman terdapat dalam Pasal 1 ayat (9) dan ayat (10) yang menyebutkan: "Perekrutan adalah 
tindakan yang meliputi mengajak, mengumpulkan membawa atau memisahkan seseorang dari keluarga atau komunitasnya. Pengiriman adalah tindakan memberangkatkan atau melabuhkan seseorang dari satu tempat ke tempat lain." ("Recruiting is the act of covering the invites, collecting or separating bring someone from the family or community. Delivery is the act of anchoring a dispatcher or someone from one place to another. ") $)^{85}$

Adapun perbuatan pengangkutan, penampungan, dan pemindahan diartikan menurut kebahasaan atau berdasarkan kamus umum bahasa Indonesia. Adapun rumusan kekerasan dalam Undang-Undang Nomor 21 Tahun 2007 tentang Pemberantasan Tinadk Pidana Perdagangan Orang Pasal 1 ayat (11) yang menyebutkan bahwa kekerasan adalah setiap perbuatan secara melawan hukum, dengan atau tanpa menggunakan sarana terhadap fisik dan psiskis yang menimbulkan bahaya bagi nyawa, badan atau menimbulkan terampasnya kemerdekaan seseorang. Adapaun ancaman kekerasan dalam Pasal 1 ayat (12) Undang-undang Nomor 21 Tahun 2007 tentang Pemberantasan Tindak Pidana Perdagangan Orang lebih terinci. Undang-Undang Nomor 21 Tahun 2007 tentang Pemberantasan Tinadk Pidana Perdagangan Orang Pasal 1 ayat (12) menyebutkan bahwa ancaman kekerasan adalah setiap perbuatan secara melawan hukum berupa ucapan, tulisan, gambar, symbol atau gerakan tubuh baik dengan atau tanpa menggunakan sarana yang menimbulkan rasa takut atau mengekang kebebasan hakiki seseorang.

Pemalsuan dalam tindak pidana perdagangan orang berkaitan dengan setiap yang memberikan atau memasukkan keterangan palsu pada dokumen Negara atau

\footnotetext{
${ }^{85}$ Ibid,,hlm. 26-27.
} 
dokumen lain atau memalsukan dokumen Negara atau dokumen lain, untuk mempermudah terjadinya tindak pidana perdagangan orang (Pasal 19). Dalam penjelasan Pasal 19 disebutkan bahwa yang dimaksud dengan dokumen Negara dalam ketentuan ini meliputi, tetapi tidak terbatas pada paspor, KTP, ijazah, Kartu keluarga, akta kelahiran,d an surat nikah dan yang dimaksud dokumen lain dalam ketentuan ini meliptui, tetapi tidak terbatas pada surat perjanjian kerja bersama, surat permintaan TKI, asuransi, dan documen terkait. ${ }^{86}$

Penyalahgunaan kekuasaan dimaksud adalah menjalankan kekuasaan yang ada padanya secara tidak sesuai tujuan pemberian kekuasaan tersebut atau menjalankan secara tidak sesuai ketentuan peraturan. Hal ini dijelaskan dalam penjelasan Undang-Undang Nomro21 Tahun 2007 tentang Tindak Pidana Perdagangan Orang Pasal 8 ayat (1).

Pengertian pemanfaatan posisi kerentanan tidak dijelaskan dalam undangundang nomor 21 tahun 2007tentang Pemberantasan Tindak Pidana Perdagangan Orang. Adapun pengertian penjeratan utang dijelaskan dalam Pasal 1 ayat (15) bahwa penjeratan utang adalah perbuatan menempatkanorang dalam status atau keadaan menjamin atau terpaksa menjaminkan dirinya atau keluarganya atau orang-orang yang menjadi tanggung jawabnya, atau jasa pribadinya sebagai bentuk pelunasan utang. Dari segi pelaku bahwa pelaku tindak pidana perdagangan orang kehilangan hak tagihnya atas utang atau perjanjian lainnya terhadap korban, jika utang atau perjanjian lainnya terhadap korban, jika utang atau perjanjian lainnya tersebut digunakan untuk mengeksploitasi korban, hal ini sesuai dengan Pasal 27

\footnotetext{
${ }^{86}$ Ibid,,hlm. 27
} 
Undang-Undang Nomor21 Tahun 2007 tentang Pemberantasan Tindak Pidana Perdagangan Orang. ${ }^{87}$

Untuk itu, penulis memberikan pemahaman tentang sumber-sumber hukum mengenai perdagangan orang. Sebagai tindak pidana, perdagangan orang telah diatur dalam KUHP yang memuat ketentuan menganai larangan memperniagakan perempuan dan anak laki-laki yang belum dewasa sebagaimana diatur dalam Pasal 297 KUHP, serta larangan meperniagaan budak belian sebagaimana diatur dalam Pasal 324 KUHP dan mengkualifikasikan tindakan-tindakan tersebut sebagai kejahatan. Dalam Pasal 297 dan Pasal 324 KUHP tidak berlaku lagi sejak disahkannya Undang-undang Nomor 21 Tahun 2007 tentang PemberantasanTindak pidana Perdagnagan Orang. Akan tetapi, didalam KUHP masih banyak pasal yang bisa di pergunakan untuk menindak sipelaku tentang tindak pidana perdagangan orang antara lain: Perhatikan tabel di bawah ini, dan mengenai ancaman hukumannya dapat dilihat dalam KUHP: ${ }^{88}$

\begin{tabular}{|l|l|}
\hline Pasal & \multicolumn{1}{|c|}{ Isi Pasal } \\
\hline 263 & Memalsukan surat-surat \\
277 & Mengaburkan asal usul seseorang \\
285 & Pengakuan palsu \\
286 & Perkosaan \\
287 & Persetubuhan dengan perempuan yang pingsan atau tidak berdaya \\
288 & Bersetubuh dengan anak perempuan berusia di bawah 15 tahun \\
289 & Persetubuhan dengan istri yang belum masanya dikawinkan \\
290 & Perbuatan cabul atau asusila \\
$292-293$ & Perbuatan asusila yang dilakukan terhadap orang yang tidak berdaya \\
294 & Perbuatan cabul dengan anak-anak yang belum dewasa \\
295 & Menfasilitasi (memuan penyalahgunaan kekuasaan \\
& belum dewasa (anak-anak) perbuatan asusila dengan orang yang \\
296 & Memudahkan perbuatan cabul sebagai mata pencarian/pekerjaan atau \\
301 & kebiasaan \\
304 & Mempekerjakan orang dibawah umur sebagai pengemis atau pekerjaan \\
328 & berbahaya \\
329 & Meninggal dalam keadaan sengsara \\
\hline
\end{tabular}

${ }^{87}$ Ibid,,hlm. 28

88 Ibid,,hlm. 28-29 


\begin{tabular}{|c|c|}
\hline $\begin{array}{l}330 \\
331\end{array}$ & $\begin{array}{l}\text { Melarikan orang yang belum dewasa dari kekuasaan orang yang berhak } \\
\text { Menyembunyikan atau mencabut orang yang belum dewasa dari } \\
\text { penyidikan }\end{array}$ \\
\hline 32 & Melarikan perempuan \\
\hline 33. & Dengan sengaja dan tanpa hak merampas kemerdekaan seseorang \\
\hline 334 & $\begin{array}{l}\text { Karena kesalahan (kelalaian:culpa/schuld) terampasnya kemerdekaan } \\
\text { orang lain } 89\end{array}$ \\
\hline 5 & Memaksa orang lain melakukan/tidak melakukan sesuatu \\
\hline 36 & Ancaman dengan kejahatan-kejahatan khusus \\
\hline & Penganiayaan \\
\hline & Penganiayaan ringan \\
\hline & Penganiayaan dengan rencana terlebih dahulu \\
\hline כא & Penganiayaan berat dengan rencana terlebih dahulu \\
\hline & Pencurian \\
\hline & Pencurian dengan kekerasan atau ancaman kekerasan \\
\hline & Pemerasan \\
\hline & Ancaman \\
\hline & Penipuan \\
\hline & Mucikari (souteneur) \\
\hline
\end{tabular}

Sumber : Departemen Kehakiman AS, Kantor Pengembangan, Asisten dan Pelatihan Kerja Sama Luar Undang-

Negeri (OPDAT) dan Kantor Kejaksaan RI (Pusdiklat), Perdagangan Manusia dan

Undang Ketenagakerjaan: Strategi Penuntutan yang Efektif, 2008, hlm 2-3

Di samping itu, perdagangan orang dilarang di dalam berbagai peraturan perundang-undangan Indonesia di luar KUHP, yaitu sebagai berikut:

1. Undang-Undang Nomor 39 Tahun 1999 tentang Hak Asasi Manusia.

2. Undang-Undang Nomor 23 Tahun 2002 tentang Perlindungan Anak.

3. Undang-Undang Nomor 23 Tahun 2004 tentang Penghapusan Kekerasan Dalam Rumah Tangga.

4. Undang-Unadng Nomor 7 Tahun 1984 tentang Penghapusan Segala Bentuk Diskriminasi terhadap Perempuan.

5. Undang-Undang Nomor 23 Tahun 1992 tentang kesehatan ${ }^{90}$

\footnotetext{
${ }^{89}$ Ibid,hlm. 29
}

90 Ibid,,hlm. 30 
6. Undang-Undang Nomor 13 Tahun 2006 tentang Perlindungan Saksi dan Korban.

7. Undang-Undang Nomor 13 Tahun 2003 tentang KetenagaKerjaan.

8. Undang-Undang Nomor 39 Tahun 2004 tentang Penempatan Perlindungan Tenaga Kerja Indonesia di Luar Negeri.

9. Undang-Undang Nomor 9 Tahun 1992 tentang Keimigrasian.

10. Undang-Undang Nomor 15 Tahun 2002 tentang Tindak Pidana Pencurian Uang.

11. Undang-Undang Nomor 20 Tahun 2001 tentang Perubahan atas UndangUndang Nomor 31 Tahun 1991 tentang Penghapusan Korupsi, dan lainlain. $^{91}$

KUHP dan peraturan perundang-undang lainnya tersebut tidak merumuskan pengertian perdagangan orang yang tegas dan lengkap secara hukum. Di samping itu, juga memberikan hukuman yang ringan dan tidak sepadan dengan dampak yang dialami korban akibat perdagangan orang tersebut. Oleh karena itu, lahir Undang-Undang Nomor 21 Tahun 2007 tentang Pemberantasan Tindak Pidana Perdagangan Orang untuk mencegah dan menanggulangi tindak pidana perdagangan orang dan melindungi korban perdagangan orang. Undang-undang ini mengatur berbagai ketentuan yang dapat mengantisipasi dan menjaring semua jenis tindak pidana eprdagangan orang,mulai dari proses dan cara, sampai kepada tujuan, dalam semua bentuk eksploitasi yang mungkin terjadi dalam perdagangan orang, baik yang dilakukan antar wilayah yang dalam negeri maupun antarnegara dan baik

\footnotetext{
91 Departemen Kehakiman AS, Kantor Pengembangan, Asisten dan Pelatihan Kerja Sama Luar Negeri (OPDAT) dan Kantor Kejaksaan RI (Pusdiklat), Perdagangan Manusia dan Undang-Undang Ketenagakerjaan: Strategi Penuntutan yang Efektif, 2008, hlm. 2-3
} 
dilakukan perorangan, kelompok maupun korporasi. Undang-undang ini juga mengatur perlindungan saksi dan korban sebagai aspek penting dalam penegakan hukum untuk memberikan perlindungan kepada korban dan/atau saksi.

Selain itu, undang-undang ini memberikan perhatian terhadap penderitaan korban akibat tindak pidana perdagangan orang dalam bentuk hak restitusi yang harus diberikan pelaku tindak pidana perdagangan orang sebagai ganti kerugian bagi korban dan mengatur hak korban atas rehabilitasi medis, psikologis dan social, pemulangan serta integrasi yang wajib dilakukan oleh Negara, khususnya bagi mereka yang mengalami penderitaan fisik, psikis dan social akibat tindak pidana perdagnagan orang. Undang-unang ini juga mengatur ketentuan tentang pencegahan dan penanganan korban tindak pidana perdagangan orang sebagai tanggung jawab pemerintah, pemerintah daerah, masyarakat, dan keluarga. Dan juga mengatur pembentukan gugus tugas untuk mewujudkan langkah-langkah yang terpadu dalam pelaksanaan pencegahan dan penanganan perdagangan orang. ${ }^{92}$

Untuk kerja sama internasional diatur juga dalam Undang-Undang Nomor 21 Tahun 2007 tentang Pemberantasan Tindak Pidana Perdagangan Orang dalam bentuk perjanjian bantuan hukum timbale balik dalam pidana dan/atau kerja sama teknis lainnya. Hal ini karna sifat dari tindak pidana perdagangan orang merupakan tindak pidana yang tidak saja terjadi dalam satu wilayah Negara, tetapi juga antar Negara. Undang-Undang Nomor 21 Tahun 2007 tentang Pemberantasan Tindak Piadna Perdagangan Orang merupakan perwujudan dari komitmen bangsa Indonesia untuk melaksanakan Protokol PBB Tahun 2000 yang telah ditandatangani pemerintah Indonesia tentang Mencegah, Menumpas TIndak Pidana

\footnotetext{
92 Farhana, op. cit., ,hlm. 31.
} 
Perdagangan Orang khususnya terhadap Perempuan dan Anak (Protokol Palermo) dan Menghukum pelakunya. ${ }^{93}$

Saat ini Indonesia sarana peraturan undang-undang sudah dapat dikatakan lengkap, sehingga dapat dilaksanakan untuk menindak atau menghukum pelaku perdagangan orang. Aparat hukum dapat menindah secara hukum terhadap pelaku perdagangan orang dengan menggunakan semua peraturan perundang-undangan hukum pidana nasional, baik instrument hukum administrasi, hukum pidana administrasi maupun hukum pidana dalam KUHP dan di Luar KUHP.

${ }^{93}$ Ibid,,hlm. 31-32. 
$B A B I V$

\section{KEPENTINGAN KORBAN DAN TERSANGKA}

DALAM PROSES PERADILAN PIDANA

Dalam Penyelidikan suatu perkara tindak pidana harus mempunyai bukti permulaan yang cukup, maksud dari hal tersebut adalah untuk memperkuat agar dalam penyidikan tidak mengambang artinya untuk mempermuda proses penyidikan yang sebenarnya serta tidak menimbulkan peristiwa baru, akan tetapi apabila dari hasil penyelidikan itu belum mempunyai bukti permulaan yang cukup agar di hentikan penyidikan oleh karena belum mempunyai bukti sebagaimana ketentuan dalam Pasal 1 ayat (2) KUHAP karena pengertian dari penyidikan adalah serangkaian tindakan penyidik dalam hal dan menurut cara yang diatur dalam undang-undang ini untuk mencari serta mengumpulkan bukti yang dengan bukti itu membuat terang tentang tindak pidana yang terjadi dan guna menemukan tersangkanya. ${ }^{94}$ Untuk itu dalam penulisan buku ini ( penghakiman Tanpa Hakim), penulis memberikan pengertian atau pemahaman agar lebih terang benderang dalam pemahaman hukum untuk mencari kepastian hukum dan keadilan antara lain;

\section{Dalam Soal Pemeriksaan Pendahuluan;}

a. Saksi yang diduga tidak dapat hadir di muka persidangan, karena berhalangan, supaya disumpah terlebih dahulu sebelum diminta

\footnotetext{
${ }^{94}$ A. Hamzah dan Irdan Dahlan, Op-cit. hlm.. 11.
} 
keterangannya sedangkan relaas panggilannya telah dapat diajukan pada hari sidang,

b. Untuk menghemat biaya pada azasnya dalam mengajukan saksi-saksi hendaknya disampaikan yang penting-penting, juga diperkirakan saksisaksi yang dapat diperiksa pada sidang yang bersangkutan. Bagi saksisaksi yang tidak dapat diajukan karena berhalangan dan telah dikemukakan relaas panggilannya, cukuplah berita acara pendahuluan dibacakan dalam persidangan,

c. Barang bukti termasuk yang berupa monster, hendaknya dibungkus dan disegel di hadapan tersangka dan ditanda tangani berita acaranya oleh verbalisan atas sumpah jabatannya dan sedapat mungkin dibubuhi tanda tangan atau cap jempol oleh tersangka yang tidak dapat menulis, dan membaca agar mendapatkan kepastian hukum.

\section{Dalam soal Penuntutan}

a. Untuk menghindarkan dikembalikannya Berkas Perkara, maka Jaksa hendaknya mengajukan Berkas Perkara selengkap mungkin, sedangkan Hakim hendaknya selalu bersikap akan mencoba menambah kekurangan tersebut dimuka sidang, dan manakala hal ini ditimbangnya tidak mungkin maka Hakim hendaknya secara terperinci meyebut halhal apa yang masih harus dilengkapi pemeriksaannya;

b. Sedapat mungkin perkara diajukan secara sumier, dengan surat tuduhan yang telah disiapkan sebelumnya, sedangkan untuk kelancaran pemeriksaan dipersidangan, maka Berkas Perkara hendaknya sudah diserahkan ke Pengadilan sedikitnya dua hari sebelum disidangkan dan 
Hakim hendaknya memanfaatkan kesempatan tersebut dengan benarbenar mempelajari Berkas Perkara sebelum disidangkan; ${ }^{95}$

c. Jika dalam satu tindak pidana tersangkut beberapa tersangka dan diantaranya ada yang dapat melarikan diri dari tahanan atau sama sekali belum dapat tertangkap, Jaksa hendaknya memecah (splits) perkara tersebut dan mengajukan hanyalah tersangka-tersangka yang lengkap saja;

d. Oleh karena tunggakan juga disebabkan karena tersangkanya sama sekali tidak dapat diajukan ke muka Pengadilan yang kecuali untuk perkara tertentu tidak berwenang mengambil keputusan bij verstek, maka untuk mengatasi hal ini, maka hendaknya Jaksa mengajukan satu perkara semacam ini, pada Pengadilan Istimewa Jakarta yang kiranya dapat diputus oleh Hakim dengan menyatakan "niet ontvankelijk". Atas putusan ini hendaknya Jaksa naik banding dan seterusnya kasasi, sehingga daparlah Mahkamah Agung mengambil keputusan mengenai soal putusan bij vertek tersebut.

\section{Dalam soal Pengadilan}

a. Hakim hendaknya menunjukan kerelaan berkorban yang lebih besar lagi dari sebelumnya sehingga bukan saja tunggakan yang berada di tangan Kejaksaan sekarang yang dapat dihabiskan, tetapi juga tugas-

95 H.Harris ${ }_{3}$ Pembaharuan Hukum Acara PIdana yang terdapat dalam H.I.R. Penerbit Binacipta, Jakarta tahun 1978, hlm. 153-154. 
tugas yang telah ada pada Pengadilan dapat pula diselesaikan seperti biasa, dan tidak pula menjadikan tunggakan baru. ${ }^{96}$

b. Kecuali dalam perkara tindak pidana subversi, tindak pidana ekonomi dan tindak pidana yang menarik banyak perhatian masyarakat, Hakim hendaknya memutus dalam sidang Hakim tunggal. Terhadap tiga jenis tindak pidana tersebut di atas dan terhadap perkara yang tersangkanya telahh lama ditahan, Hakim hendaknya memberikan prioritas pemeriksaan. Jika dalam pekara yang sudah bersidang dengan 3 Hakim diantaranya kemudian ada yang berhalangan, maka Kepada Pengadilan Negeri hendaknya segera menunjuk penggantinya.

c. Hakim tunggal yang meneruskan perkara rekannya yang berhalangan tidak perlu kembali menggulangi pemeriksaan, tetapi cukup dengan membacakan Berita Acara Pemeriksaan yang terdahulu.

d. Hakim hendaknya tidak menuntut diajukannya seluruh barang bukti, tetapi cukup meminta diajukannya monster, atau Berita Acara Penyitaan atau surat-surat bukti mengenai hak milik dari barang bukti, kecuali jika tersangka menghendakinya.

e. Jika telah mencukupi keyakinannya Hakim dapat memutus dengan satu saksi.

f. Dengan tidak mengurangi urgensi dari penyelesaian tunggakantunggakan, hakim hendaknya tetap memeriksa secara teliti dan seksama serta membuat Berita Acara Persidangan selengkap-lengkapnya.

\footnotetext{
${ }^{96}$ H.Harris, Ibid, hlm. 154.
} 
g. Hakim hendaknya baru memasukkan perkara sumier dalam register Pengadilan setelah perkara tersebut betul-betuk dapat disidangkan.

\section{Dalam soal Pemanggil Tersangka/Saksi}

a. Sangat sering terjadi perkara ditunda-tunda sebab tersangka/saksisaksi tidak dapat diajukan disebabkan petugas mendapat keterangan bahwa tersangka/saksi-saksi tidak berada di tempat.

b. Petugas pemanggil hendaknya mencatat nomor Kartu Penduduk dari yang memberi keterangan dan kemudian menceknya pada Ketua RT atau RW/Kepala Kampung. Jika ternyata keterangannya palsu hendaknya dimintakan pertanggungjawabnya. Sebagai ceking kedua maka panggilan kedua hendaknya dilakukan oleh Petugas pemanggil yang lain.

\section{Dalam soal biaya Perkara/Biaya Tambahan yang disediakan oleh Pemerintah Pusat. ${ }^{97}$}

a. Biaya perkara yang akan dibebankan kepada terhukum sesuai dengan putusan Hakim yang meliputi ongkos saksi, uang sumpah dan biaya administrasi yang ditentukan jumlahnya, oleh Jaksa hendaknya betulbetul dilaksanakan sesuai dengan ketentuan yang ada;

b. Supaya biaya tambahan yang disediakan Pemerintah khusus untuk menyelesaikan tunggakan-tunggakan perkara dapat dimanfaatkan sesuai dengan tujuannya hendaknya biaya tersebut dibagi menurut kebutuhan masing-masing instansi, yaitu Kepolisian, Kejaksaan dan

\footnotetext{
${ }^{97}$ Ibid, hlm. 154-155.
} 
Pengadilan Negeri, dan baru dipertanggungjawabkan seteleh perkara diputus.

\section{Hal-hal yang harus diperhatikan dalam permasalahan tahanan;}

a. Supaya hak-hak azasi tidak hanya merupakan kata-kata mutiara belaka hendaknya Jaksa, Polisi, Hakim dan Kepala Lembaga Pemasyarakatan secara bersungguh-sungguh memperhatikan tahanan sementara, baik mengenai surat perintah penahannnya, maupun mengenai perpanjangan penahanan;

b. Kerjasama diantara keempat instansi harus diatur sedemikian rupa sehingga secara berangsur-angsur dan akhirnya tidak akan ada lagi tahanan sementara yang melebihi satu tahun;

c. Jika Hakim memerlukan laporan Pemeriksaan Pendahuluan yang diperlukan untuk memberikan perpanjangan penahanan, maka Jaksa/Kepolisian wajib memberikannya.

d. Supaya Jaksa dan Hakim memberikan perhatian khusus terhadap tahanan-tahanan lama dan menyelesaikan perkara tersebut selekas mungkin. ${ }^{98}$

Kurang lebih dua setengah tahun setelah pertemuan Cibogo itu dalam tahun 1970 Jaksa Agung Sugih Arto mengambil prakarsa lagi untuk mengadakan pertemuan yang kedua antara Kejaksaan Agung, Mahkamah Agung, Kepolisian dan Departemen Kehakiman dengan maksud untuk lebih meningkatkan saling pengertian dan kerjasama yang telah tercapai demi terlaksananya Tertib Hukum.

\footnotetext{
${ }^{98}$ Ibid, hlm. 155-156.
} 
Di dalam pertemuan tersebut semua pihak menyadari bahwa masih terdapat adanya perbedaan di dalam pelaksanaan tugas penegakan hukum sebagai akibat dari ketidak serasian antara beberapa peraturan yang berhubungan dengan proses perkara pidana. Di samping itu diinsyafi pula bahwa perbedaan pendapat tersebut tidak dapat dibiarkan terus-menerus. Sebab hal ini akan tetap merupakan hambatan di dalam melaksanakan wewenang dan tugas penegakan hukum, yang akhirnya dapat menjurus kearah, ketidak pastian hukum yang sudah tentu akan sangat merugikan masyarakat. Kesadaran tersebut di atas menuntut dilakukannya usahausaha untuk meningkatkan kerjasama dalam hubungan fungsionil yang wajar antara alat-alat Negara Penegah Hukum berdasarkan musyawarah dan mufakat. Dan akhirnya semua itu dituangkan dalam satu Surat Keputusan Bersama yang pada pokoknya mengatur tentang "landasan dan ketentun-ketentuan kegiatan bersama Alat-alat Negara, Penegak Hukum', dimana ketentuan-ketentuan dalam H.I.R tetapi dianggap sebagai hukum positif yang berlaku. Sebagai materie dari Surat Keputusan tersebut antara lain tercantum: ${ }^{99}$

\section{Masalah Tahanan}

1. Status Tahanan serta penjelasannya terdiri atas;

a) Undang-undang tidak mengenal istilah tahanan Kepolisian, Kejaksaan dan Pengadilan. Undang-undang hanya mengenal istilah penangkapan sementara dan penahanan sementara, dimana Kepolisian dapat menahan seseorang selama 20 hari, Kejaksaan 30 hari dan

\footnotetext{
${ }^{99}$ Ibid, hlm. 157.
} 
perpanjangan atas permintaan Jaksa, oleh Hakim setiap kali selama 30 hari (Pasal 75 jo 62 ayat (2) R.I.B) ${ }^{100}$

b) Pertanggungjawaban secara yuridis dibebankan pada instansi yang melakukan penahanan. Pertanggungjawaban physic mengenai pemeliharaan, perawatan dan keamanan dibebankan pada instansi yang pertama melakukan penahanan kecuali tahanan yang telah diserahkan pada Lembaga Pemasyarakatan.

c) Untuk lebih menjamin kemerdekaan pribadi seseorang serta demi pertanggungjawaban menurut hukum supaya pihak Kepolisian secepat mungkin dan selambat-lambatnya dalam waktu 8 hari memberitahukan tahanan tersebut pada Jaksa dengan mengirimkan sehelai salinan Surat Perintah Penahanan yang bersangkutan (Pasal 83k ayat (3) R.I.B)

d) Dalam hal pemeriksaan perkara yang tidak dapat diselesaikan dalam waktu 20 hari, sedangkan pihak Kepolisian menganggap perlu penahanan dilanjutkan, maka perpanjangan penahanan dimintakan kepada Jaksa sebelum lewat 30 hari dengan mengikutsertakan sehelai resume pemeriksaan sementara (Pasal 38k ayat (4) R.I.B)

e) Dalam hal Jaksa meminta perpanjangan kepada Hakim, permintaan itu harus dilakukan sebelum lewat 30 hari semenjak perpanjangan penahanan oleh Jaksa (Pasal83c ayat (4) R.I.B)

f) Atas permintaan perpanjangan dari Jaksa ini, Hakim memberikan perpanjangan untuk 30 hari dan selanjutnya tiap-tiap kali untuk 30 hari, 
apabila hal itu diminta oleh Jaksa dan apabila Hakim memandang perlu (Pasal 83c ayat (4) R.I.B)

g) Untuk Keperluan perpanjangan penahanan oleh Hakim, Hakim berhak meminta resume/hasil-hasil pemeriksaan yang berhubungan dengan perkara itu kepada Jaksa (Pasal 83d ayat (1) R.I.B)

h) Hakim berwenang meminta surat-surat yang berhubungan dengan perkara yang dikemukakan kepadanya dan setelah memperoleh keterangan dari Jaksa memerintahkan supaya pemeriksaan disudahi dengan segera. Kalau ada alasan untuk itu ia dapat menetapkan bila pemeriksaan selambat-lambatnya harus sudah diselesaikan (Pasal 83d ayat (1) R.I.B).

i) Pengadilan agar mengadakan administrasi tahanan. Untuk keperluan itu diwajibkan kepada instansi yang yuridis maupun physic bertanggungjawab atas penahanan itu memberikan keteranganketerangan kepada Pengadilan bila ada perobahan status tahanan.

2. Langkah-langkah atau tata cara untuk melakukan Pengeluaran tahanan sementara antara lain adalah sebagai berikut;

a) Selama perkara belum diserahkan ke Pengadilan, maka pengeluaran tahanan-tahanan yang penahanannya sudah diperpanjang oleh Jaksa dilakukan dengan Surat Perintah pengeluaran dari tahanan oleh Jaksa (Pasal 83j ayat (3) R.I.B)

b) Selama perkara belum diserahkan ke Pengadilan, maka pengeluaran tahanan-tahanan dengan surat perintah pengeluaran dari penahanan Jaksa tersebut, apabila sudah pernah mendapat perpanjangan dari 
Hakim. Pengeluaran tersebut diberitahukan oleh Jaksa kepada Hakim (Pasal 83j ayat (3) R.I.B.).

3. Tujuan dari pada pengawalan adalah sebagai berikut;

Pengawalan tahanan untuk kepentingan penyidangan perkara dilakukan oleh kepolisian.

\section{B. Barang Bukti}

Penyitaan bertujuan untuk membuktikan kebenran hukum dimana hal tersebut terdiri dari; ${ }^{101}$

A. Sesuai dengan peraturan yang berlaku yang dapat disita hanya barangbarang yang menurut hukum dapat dijadikan bukti;

B. Instansi yang melakukan penyitaan atau yang menerima barang bukti, bertanggung jawab atas keselamatan dan keamanan barang-barang bukti tersebut dan wajib menyerahkannya kepada pengadilan untuk kepentingan persidangan perkara sebagimana yang dimaksud.

\section{Penyelesaian Perkara}

1. Putusan Hakim bertujuan untuk; ${ }^{102}$

a. Dalam hal putusan hakim sudah mempunyai kekuatan hukum yang tetap, Panitera segera setelah sidang menyerahkan kepada Jaksa dan kepolisian petikan putusan Hakim (Pasal 325 ayat(3) R.I.B),

b. Dalam hal terhadap putusan Hakim dimintakan banding sangat diharapkan agar pengadilan mengirimkan berkas perkara dalam waktu 
yang ditentukan oleh Undang-undang kepda Pengadilan Tinggi (Pasal10 ayat (1) UU No. 1 Drt., Thn 1951),

c. Dalam hal diajukan permohonan grasi kepada PresidenPengadilan yang bersangkutan mengusahakan agar berkas perkara secepat-cepat dikirimkan kpada Kejaksaan yang pada gilirannya berkewajiban dalam waktu yang singkat meneruskannya kepada Mahkamah Agung (Pasal88UU Grasi LN Thn 1950 No. 40),

d. Putusan Hakim tentang pengembalian barang bukti menyebutkan secra tegas nama orang atau badan yang berhak menerima barng bukti (Pasal 316 ayat (1) jo. 619 ayat (1) R.I.B.)

\section{Executie}

Jaksa selaku execeteur/penanggungjawab pelaksanaan putusan Hakim harus segera/selekas mungkin melaksanakan putusan Hakim baik yang menyangkut orang maupun yang menyangkut barang bukti (Pasal325 R.I.B. JO Pasal 2 UUPokok Kejaksaan).

\section{Tentang permasalahan Pembiayaan Pentidikan, Penyidangan dan}

\section{Penyelesaian Perkara antara lain; ${ }^{103}$}

1. Untuk pembiayaan penyidikan, penyidangan dan penyelesaian perkara harus disediakan biayaa yang cukup oleh Pemerintah,

2. Biayaa pemeriksaan pendahuluan, pemeriksaan dimuka sidang Pengadilan dan penyelesaian perkara di urus oleh masing-masing instansi yang secara Physik melakukan tindakan-tindakan tersebut,

\footnotetext{
${ }^{103}$ Ibid, hlm. 160.
} 
3. Biaya yang dimaksud dalam sub 1 dan 2 adalah;

a. Biaya pemanggilan saksi-saksi dan terdakwa baik untuk kepentingan penyidikan maupun penyidangan,

b. Biayaa penyidikan/operasi

4. Biayaa perawatan tahanan-tahanan supaya diurus oleh instansi dimana orang itu ditahan,

5. Biayaa penanggulangan tunggakan perkara akan diusahakan secara khusus.

E. Untuk kepentingan penyidikan maka memerlukan kepastian hukum dengan mengunakan penelitian secara Statistik agar lebih jelas kebenaran atau jumlah kejahatan yang secara pasti;

1. Untuk memperoleh data-data yang lengkap mengenai kejahatan dan pelanggran perlu diaktifkan kembali pengiriman model A dari Kepolisian kepada Kejaksaan, sedangkan sebaliknya setiap penetapan/ penyelesaian perkara dibertahukan oleh Kejaksaan kepada Kepolisian,

2. Mengingat statistic criminal mempunyai arti penting bagi Negara dan sesuai pula denga keputusan seminar kriminologi di Semarang, mak perlu dibentuk suatu lembaga/badan koordinasi yang bertugas menyelenggarakan statistic criminal dibawah pimpinan Jaksa Agung.

Sedangkan dalam Ketentuan Umum Bab I KUHAP memberikan beberapa pengertian antara lain adalah sebagi berikut; 
1. Penyidik adalah pejabat Polisi Negara Republik Indonesia atau pejabat pegawai negeri sipil tertentu yang diberi wewenang khusus oleh undangundang untuk melakukan penyidikan.

2. Penyidikan adalah serangkaian tindakan penyidik dalam hal dan menurut cara yang diatur dalam undang-undang ini untuk mencari serta mengumpulkan bukti yang dengan bukti itu membuat terang tentang tindak pidana yang terjadi dan guna menemukan tersangkanya.

3. Penyidik pembantu adalah Pejabat Kepolisian Negara Republik Indonesia yang karena diberi wewenang tertentu dapat melakukan tugas penyidikan yang diatur dalam undang-undang ini.

4. Penyidik adalah Pejabat Polisi Negara Republik Indonesia yang diberi wewenang oleh undang-undang ini untuk melakukan penyelidikan.

5. Penyelidikan adalah serangkaian tindakan penyidik untuk mencari dan menemukan suatu peristiwa yang diduga sebagai tindak pidana guna menentukan dapat atau tidaknya dilakukan penyidikan menurut cara yang diatur dalam undang-undang. ${ }^{104}$

6. a. Jaksa adalah pejabat yang diberi wewenang oleh undang-undang ini untuk bertindak sebagai penuntut umum serta melaksanakan putusan pengadilan yang telah memperoleh kekuatan hukum tetap.

b. Penuntut umum adalah jaksa yang diberi wewenang oleh undangundang ini untuk melakukan pernuntutan dan melaksanakan penetapan hakim.

104 A. Hamzah dan Irdan Dahlan, Op-ci, .hlm.. 11-12. 
7. Penuntutan adalah tindakan penuntut umum untuk melimpahkan perkara pidana ke pengadilan negeri yang berwenang dalam hal dan menurut cara yang diatur dalam undang-undang ini dengan permintaan supaya diperiksa dan diputus oleh hakim disidang pengadilan.

8. Hakim adalah pejabat peradilan Negara yang diberi wewenang oleh undang-undang untuk mengadili

9. Mengadili adalah serangkaian tindakan hakim untuk menerima, memeriksa dan memutus perkara pidana berdasarkan asas bebas, jujur dan tidak memihak disidang pengadilan dalam hal dan menurut cara yang diatur dalam undang-undang ini.

10. Praperadilan adalah wewenang pengadilan negeri untuk memeriksa dan memutus menurut cara yang diatur dalam undang-undang ini, tentang:

a. Sah atau tidaknnya suatu penangkapan dan atau penahanan atas permintaan tersangka atau keluarganya atau pihak lain atau kuasa tersangka;

b. Sah atau tidaknya penghentian penyidikan atau penghentian penuntutan atas permintaan demi tegaknya hukum dan keadilan;

c. Permintaan ganti kerugian atau rehabilitasi oleh tersangka atau keluarganya atau pihak lain atas kuasanya yang perkaranya tidak diajukan kepengadilan.

11. Putusan pengadilan adalah pernyataan hakim yang diucapkan dalam sidang pengadilan terbuka, yang dapat berupa pemidanaan atau bebas 
atau lepas dari segala tuntutan hukum dalam hal serta menurut cara yang diatur dalam undang-undang ini. ${ }^{105}$

12. Upaya hukum adalah hak terdakwa atau penuntut terdakwa atau penuntut umum untuk tidak menerima putusan pengadilan yang berupa perlawanan atau banding atau kasasi atau hak terpidana untuk mengajukan permohonan peninjauan kembali dalam hal serta menurut cara yang diatur dalam undang-undang ini.

13. Penasihat hukum adalah seorang yang memenuhi syarat yang ditentukan oleh atau berdasar undang-undnag untuk member bantuan hukum.

14. Tersangka dalah seorang yang karena perbuatannya atau keadaanya, berdasarkan bukti permulaan patut diduga sebagai pelaku tindak pidana.

15. Terdakwa adalah seorang tersangka yang dituntut, diperiksa dan diadili di sidang pengadilan.

16. Penyitaan adalah serangkaian tindakan penyidik untuk mengambil alih dan atau menyimpan di bawah penguasaannya benda bergerak atau tidak bergerak, berwujud atau tidak berwujud untuk kepentingan pembuktian dalam penyidikan, penuntutan dan peradilan.

17. Penggeledahan rumah adalah tindakan penyididk untuk memasuki rumah tempat tinggal dan tempat tertutup lainnya untuk melakukan tindakan pemeriksaan dan atau penyitaan dan atau penangkapan dalam hal dan menurut cara yang diatur dalam undang-undang ini.

18. Penggeledahan badan adalah tindakan penyidik untuk mengadakan pemeriksaan badan dan atau pakaian tersangka untuk mencari benda

${ }^{105}$ A. Hamzah dan Irdan Dahlan,Ibid, Hlm.. 13-14. 
yang diduga keras ada pada badannya atau dibawanya serta, untuk disita. ${ }^{106}$

19. Tertangkap tangan adalah tertangkapnya seorang pada waktu sedang melakukan tindak pidana, atau dengan segera sesudah ebberapa saat tindak pidana itu dilakukan, atau sesaat kemudian diserukan oleh khalayak ramai sebagai orang yang melakukannya, atau apabila sesaat kemudian padanya ditemukan benda yang diduga keras telah dipergunakan untuk melakukan tindak pidana itu yang menunjukan bahwa ia adalah perlakunya atau turut melakukan atau membantu melakukan tindak pidana itu.

20. Penangkapan adalah suatu tindakan penyidik berupa pengekangan sementara waktu kebebasan tersangka atau terdakwa apabila terdapat cukup bukti guna kepentingan penyidikan atau penuntutan dan atau peradilan dalam hal serta menurut cara yang diatur dalam undangundang ini.

21. Penahanan adalah penempatan tersangka atau terdakwa di tempat tertentu oleh penyidik atau penuntut umum atau hakim dengan penetapannya, dalam hal serta menurut cara yang diatur dalam undangundang ini.

22. Ganti kerugian adalah seorang untuk mendapat pemenuhan atas tuntutannya yang berupa imbalan sejumlah uang karena ditangkap, ditahan, dituntut ataupun diadili tanpa alasan yang berdasarkan undang-

106 A. Hamzah dan Irdan Dahlan ,Ibid, Hlm.. 15-16. 
undang atau karena kekeliruan mengenai orangnya atau hukum yang diterapkan menurut cara yang diatur dalam undang-undang ini.

23. Rehabilitasi adalah hak seorang untuk mendapat pemulihan haknya dalam kemampuan, kedudukan dan harkat serta martabatnya yang diberikan pada tingkat penyidikan, penuntutan atau peradilan karena ditangkap, ditahan, dituntut ataupun diadili tanpa alasan yang berdasarkan undang-undnag atau karena kekeliruan mengenai orangnya atau hukum yang diterapkan menurut cara yang diatur dalam undangundang ini. ${ }^{107}$

24. Laporan adalah pemberitahuan yang disampaikan oleh seorang karena hak atau kewajiban berdasarkan undang-undang kepada pejabat yang berwenang tentang telah atau sedang atau diduga akan terjadinya peristiwa pidana.

25. Pengaduan adalah pemberitahuan disertai permintaan oleh pihak yang berkepentingan kepada pejabat yang berwenang untuk menindak menurut hukum seorang yang telah melakukan tindakn pidana aduan yang merugikannya.

26. Saksi adalah orang yang dapat memberikan keterangan guna kepentingan penyidikan, penuntutan dan peradilan tentang suatu perkara pidana yang ia dengar sendiri, ia lihat sendiri dan ia alami sendiri.

27. Keterangan saksi adalah salah satu alat bukti dalam perkara pidana yang berupa keterangan dari saksi mengenai suatu peristiwa pidana yang dia

\footnotetext{
${ }^{107}$ A. Hamzah dan Irdan Dahlan, Ibid, hlm. 17-18.
} 
dengar sendiri, ia lihat sendiri dan ia alami sendiri dengan menyebut alasan dari pengetahuannya itu.

28. Keterangan ahli adalah keterangan yang diberikan oleh seorang yang memiliki keahlian khusus tentang hal yang diperlukan untuk membuat terang suatu perkara pidana guna kepentingan pemeriksaan.

29. Keterangan anak adalah keterangan yang diberikan oleh seorang anak tentang hal yang diperulakan untuk membuat terang suatu perkara pidana guna kepentingan pemeriksaan dalam hal serta menurut cara yang diatur dalam undang-undang ini.

30. Keluarga adalah mereka yang mempunyai hubungan darah sampai derajat tertentu atau hubungan perkawinan dengan mereka yang terlibat dalam suatu proses pidana sebagaimana diatur dalam undang-undang ini.

31. Satu hari adalah dua puluh empat jam dan satu bulan adalah waktu tiga puluh hari.

32. Terpidana adalah seorang yang dipidana berdasarkan putusan pengadilan yang telah memperoleh kekuatan hukum tetap. ${ }^{108}$

\section{Pasal 1}

Cukup jelas.

\section{KOMENTAR}

Beberapa definisi di dalam Pasal 1 KUHAP ini merupakan inovasi, bukan saja dari HIR, bahkan juga dari Ned.Sv., umpamanya diberdakan pengertian tersangka (sebelum penuntutan) dan terdakwa (sesudah penuntutan). Ned.Sv. keduanya disebut verdachte. Juga dibedakan pengertian penyelidikan dan

108 A. Hamzah dan Irdan Dahlan,Ibid, Hlm..18-20. 
penyidikan dimana dalam HIR tidak demikian. Penyelidikan menurut definisi terbuat, merupakan pendahuluan (... dapat atau tidaknya dilakukan penyidikan) suatu penyidikan. Di dalam PP Nomor 27 Tahun 1982 telah ditentukan siapa yang dibebani tugas melakukan penyelidikan dan penyidkan itu.

Dalam definisi "penyidikan" dapat dilihat suatu pengertian dimana sebagai suatu tindakan pertama acara pidana, harus dilakukan menurut cara yang diatur dalam undang-undang. Ini parallel dengan Pasal 1 Ned.Sv., dimana dicantumkan bahwa acara pidana hanya dijalankan berdasarkan ketentuan undang-undang.

Meskipun definisi-definisi tersebut masih ada yang kurang jelas, namun ini merupakan hal yang benar-benar baru karena tidak terdapat di dalam HIR. Ketentuan ini merupakan suatu ketentuan definitif, serta merupakan pegangan otentik para penegak hukum dan membuat peraturan pelaksanaan, untuk menghindari penafsiran yang keliru. Ini penting untuk mencapai pengertian yang sama bagi semua pihak dan tentu lebih menjamin kepastian hukum. ${ }^{109}$

\footnotetext{
${ }^{109}$ A. Hamzah dan Irdan Dahlan,Ibid, Hlm..20.
} 
MEMPERTAHANKAN KEHORMATAN :

\section{PERJUANGAN YANG TIDAK PERNAH BERHENTI}

Kehormatan adalah Perjuangan yang tidak pernah berhenti. Oleh karenaa itu Secara filosofis menurut pendapat penulis dalam buku" Penghukuman Tanpa Hakim" adalah merupakan kekuatan funda mental demi menjaga harga diri dan martabat seseorang dalam mencapai suatu tujuan yang sangat diharapkan oleh siapa saja yang merasa masih mempunyai nilai-nilai moral, etika serta keperibadian yang menjadi prinsip tauladan dalam setiap mengambil suatu keputusan demi tegaknya hukum dan keadilan.

Berdasarkan pandangan penulis yang berkaitan dengan kehormatan adalah Perjuangan yang tidak pernah berhenti, namun aturan dan peraturan tidak dapat terlepaskan begitu saja, karena Negara kita adalah Negara hukum bukan Negara kekuasaan, untuk itu penulis menjelaskan bahwa; Negara Kesatuan Republik Indonesia adalah Negara hukum yang berkonstitusi secara tertulis. Didalam konstitusi tersebut terdapat pasal yang menjadi rujukan atau tauladan dalam pandangan secara ilmiah untuk menjaga kestabilan, kedudukan, harga diri, maupun kenyamanan dalam menjalankan roda kepemerintahan.

Dalam Undang-Undang Dasar Negara Republik Indonesia Tahun 1945 Bab X Pasal 27 ayat (1) berbunyi;

“ Setiap warga Negara bersamaan kedudukannya dalam hukum dan pemerintahan dan wajib menjujung hukum dan pemerintahan itu dengan tidak ada kecualinya." 
Menjujung hukum sangat bermakna "mematuhi hukum" atau berprilaku sesuai aturan hukum yang ditetapkan baik secara tertulis maupun tidak tertulis. Hukum dalam hal ini adalah hukum yang tidak bertentangan dengan konstitusi. ${ }^{110}$

Pada bidang hukum pidana, masyarakat pada umumnya ingin kepastian hukum sebagaimana telah dirumuskan pada Pasal 1 ayat (1) Kitab Undang-Undang Hukum Pidana (KUP) yang dikenal sebagai asas Ansem Avon Feeuerback (17751833) yang dirumuskan sebagai berikut; "Nullum delictum nulla poena sine praevia lege poenali"

Yang mana asas tersebut dirumuskan dalam KUHP adalah sebagai berikut.

“ Tiada suatu perbuatan dapat dipidana kecuali atas kekuatan aturan pidana dalam perundang-undangan yang telah ada, sebelum perbuatan dilakukan.

Berdasarkan bunyi Pasal 1 ayat (1) KUHP, para pakar hukum membuat unsur-unsurnya sebagai berikut;

a. Harus ada norma pidana tertentu, suatu norma hukum pidana yang mengandung ancaman hukuman (sanksi) terhadap perbuatan yang melanggarnya,

b. Norma hukum pidana itu harus berdasarkan suatu undang-undang. Dalam hal ini perlu diperhatikan suatu undang-undang. Dengan demikian, bukan bentuk peraturan-peraturan yang bukan undang-undang. Undang-undang dibuat bersama-sama oleh pemerintah dan Dewan Perwakilan Rakyat sebagai badan atau instansi yang berwenang sesuai dengan Pasal 20 ayat (1) Undang-Undang Dasar Negara Republik Indonesia Tahun 1945 yang bunyinya adalah sebagai berikut.

${ }^{110}$ Leden Marpaung. Tindak Pidana Terhadap Kehormata. Penerbit. Sinar Grafika. Jakarta Tahun 2010 Hlm.1 
"Dewan Perwakilan Rakyat memegang kekuasaan membentuk undangundang. Norma hukum pidana itu, telah berlaku sebelum perbuatan dilakukan, hal ini mengandung makna bahwa undang-undang tidak dapat berlakuk surut.

Apapun yang telah dirumuskan dalam Pasal 1 ayat (1) KUHP tersebut, dikenal juga asas legalitas. Embrio dari asas tersebut dicetuskan Montesquieu dalam bukunya L'Esprit des Lois (1748) denga tujuan untuk melindungi manusia terhadap tindakan sewenang-wenang oleh oknum-oknum yang tidak dapat mempertanggung jawabkan perbuatannya secara hukum.

Anseln von Feurback dalam bukunya Lehrubuch des Frein Lichen Rechts (1801) mengutarakan bahwa untuk mencegah kejahatan (prevensi) diperlukan ancaman hukuman yang dapat menahan manusia untuk tidak melakukan kejahatan.

Asas legalitas tersebut, menurut L.J van Apeldoorn dalam bukunya Inleiding tot de studie van het Nederlandse-Recht (1995), mengutarakan bahwa kepastian hukum mempunyai 2 (dua) sisi. Sisi pertama adalah bahwa ada hukum yang pasti bagi suatu peristiwa yang konkret. Sisi kedua adalah bahwa adanya perlindungan terhadap kesewenang-wenang.

Terhadap kepastian hukum ini, tampaknya masih belum adanya kesatuan persepsi. Hal ini kelihatan dari rencana KUHP tahun 1993 yang dirumuskan Pasal 1 ayat (3) dan Pasal 2 ayat (2) serta Pasal 2 ayat (3), yang dapat berdampak keraguan-raguan terhadap "kepastian hukum". Agar lebih jelas, perlu pengamatan yang cermat terhadap pasal-pasal tersebut. ${ }^{111}$

Pasal 1 ayat (3) berbunti sebagai berikut.

\footnotetext{
${ }^{111}$ Leden Marpaung. Tindak Pidana Terhadap Kehormata. Penerbit. Sinar Grafika. Jakarta Tahun 2010 , Ibid, hlm 3 .
} 
"ketentuan dalam ayat (1) tidak mengurangi berlakunya hukum yang hidup yang menentukan bahwa menurutu adat setempat seseorang patut dipidana walaupun perbuatan itu tidak diatur dalam peraturan perundang-undangan.

Pasal 2 ayat (2) berbunyi sebagai berikut.

“Apabila setelah putusan pemidanaan memperoleh kekuatan hukum tetap, perbuatan yang dilakukan membuat tidak lagi merupakan tindak pidana menurut peraturan perundang-undangan yang baru, maka terpidana harus dilepaskan dari penahanan atau penjara".

Pasal 2 ayat (3) berbunyi sebagai berikut.

“Apabila setelah putusan pemidanaan memperoleh kekuatan hukum tetap, perbuatan yang dilakukan pembuat diancam pidana lebih ringgan oleh peraturan perundang-undangan yang baru, maka putusan pemidanaan harus disesuaikan dengan batas-batas ancaman pidana menurut ketentuan baru”.

Rumusan-rumusan Pasal 1 ayat (3), Pasal 2 ayat (2) dan ayat (3) bertentangan dengan Pasal 1 ayat (1). Kepastian hukum secara nyata direalisasikan dengan adanya kaidah hukum yang ditegakkan dan dilaksanakan sebagaimana diutarakan

Dr. Soerjono Soekanto,S.H, yang antara lain, sebagai berikut.

"Kepastian hukum mengharuskan diciptakannya peraturan umum atau kaidah hukum yang berlaku umum. Agar terciptanya suasana yang aman dan tenteram dalam masyarakat maka kaidah termaksud harus ditegakkan serta dilaksanakan dengan tegas". (Penegakan Hukum, Bina Cipta, 1983, 42)

Dengan demikian, putusan pengadilan yang telah memperoleh kekuatan hukum tetap, seyogianya tidak perlu dipermasalahkan melainkan harus dilaksanakan. Memang, berdasarkan ilmu hukum pidana, hal ini tidak mutlak tetapi secara khusus, yang merupakan pengecualian, ada kalanya "putusan pengadilan yang telah memperoleh kekuatan hukum tetap". Masih dipermasalahkan, misalnya dalam hal upaya hukum luar biasa, yakni kasasi Jaksa Agung demi kepentingan hukum dan Peninjauan Kembali (PK), tetapi kedua hal tersebut tidak menunda 
eksekusi atau pelaksanaan, sehingga pada hakikatnya penerapan hukum telah usai dan tidak memerlukan penerapan ulang. ${ }^{112}$

Pembagian tindak pidana dalam KUHP terdiri atas Kejahatan dan Pelanggaran. Pembagian ini tampaknya dalam Rancangan Undang-Undang KUHP 1993, akan dihapus.

Pembentuk undang-undang membedakan tindak pidana atas "kejahatan" dan "pelanggaran" tersebut berdasarkan kualifikasi tindak pidana yang sungguhsungguh dan tindak pidana kurang sungguh-sungguh.

Di Prancis dan Belgia, tindak pidana dibagi dalam 3 (tiga) bagian, yakni:

a. Crimes (kejahatan),

b. Delits (delik),

c. Contraventions (pelanggaran).

Para pakar hukum membagi tindak pidana berdasarkan rublik-rublik yakni:

a. Tindak pidana terhadap ketertiban umum yang mencakup keamanan Negara, martabat kepala negara, para kepala Negara sahabat, kewajiban dan hak kenegaraan, tata tertib dan keamanan umum, penguasa umum, peradilan, keuangan, meterai dan cap;

b. Tindak pidana terhadap kesusilaan;

c. Tindak pidana terhadap "orang" yang mencakup: kehormatan, rahasia, kemerdekaan pribadi, nyawa, badan, dan harta.

Tindak pidana terhadap “orang” oleh sebagian pakar dibagi atas 3 (tiga) bagian, yakni:

${ }^{112}$ Leden Marpaung. Tindak Pidana Terhadap Kehormata. Penerbit. Sinar Grafika. Jakarta Tahun 2010 s Ibid, hlm 3-4. 
a) Tindak Pidana penghinaan,

b) Tindak Pidana terhadap tubuh dan nyawa, dan

c) Tindak Pidana terhadap kekayaan.

Diluar pembagian-pembagian tersebut, dalam KUHP masih ada tindak pidana yang diatur tersendiri, antara lain: ${ }^{113}$

1. Tindak Pidana jabatan, dan

2. Tindak Pidana pelayaran.

Seyogianya, peraturan perundang-undangan yang mengatur dan merumuskan tindak pidana, dimuat dalam KUHP agar dengan demikian berada dalam satu sistem. Kesatuan sistem tersebut tampaknya kurang mendapat perhatian dari pembuat undang-undang, sehingga tindak pidana diatur dan dirumuskan di luar KUHP, misalnya: Undang-Undang Nomor 17 Tahun 2008 tentang Pelayaran, memuat antara lain, tindak pidana pelayaran pada Bab XIX, yakni Pasal 284 sampai dengan Pasal 336 tanpa mengacu pada tindak pidana pelayaran yang dirumuskan pada KUHP.

Jika kesatuan sistem hukum pidana dianut, maka Pasal 284 sampai Pasal 336 Undang-Undang Nomor 17 Tahun 2008, akan menggantikan Pasal 438 sampai dengan Pasal 478 KUHP.

Pada perumusan materi hukum pidana yang akan datang diperlukan kecermatan dan ketelitian yang tinggi, sehingga tindak pidana yang telah diatur dengan undang-undang tersendiri, dapat dialihkan pada KUHP, misalnya:

1. Tindak Pidana Kehutanan,

${ }^{113}$ Leden Marpaung. Tindak Pidana Terhadap Kehormata. Penerbit. Sinar Grafika. Jakarta Tahun 2010, Ibid, hlm 4-5. 


\section{Tindak Pidana Perindustrian,}

\section{Tindak Pidana Lingkungan Hidup,}

4. Tindak Pidana Imigrasi dan lain-lain.

Dalam buku "Penghukuman Tanpa Hakim tersebut" penulis memberikan warna atau pandangan tentang "kedudukan hak milik" agar dalam memenuhi hak milik tidak ada oknum-oknum yang dapat memanfaatkan kesempatannya dalam melakukan tindakan yang tidak sesuai dengan persedural hukum yang berlaku. ${ }^{114}$

Secara hak milik, keadilan dan kemakmuran tinjauan filsafat hukumnya memberikan pandangan sebagai berikut, pandangan tersebut adalah; "sebagai mahluk sosial yang merdeka, setiap orang mempunyai bermacam hak untuk menjamin dan mempertahankan kehidupan dan penghidupannya ditengah-tengah masyarakat." Hak yang dipunyai seseorang dalam kelangsungan hidupnya tersebut pada dasarnya dapat kita bedakan atas dua jenis utama bila dipandang menurut sifatnya, yakni:

1. Hak yang bersifat asasi, yaitu hak yang harus ada pada setiap orang untuk dapat hidup secara wajar sebagai individu yang sekaligus juga angora masyarakat selaras dengan harkat dan martabatnya sebagai pribadi yang terhormat.

2. Hak yang tidak bersifat asasi, yaitu hak yang secara wajar boleh dimiliki oleh seseorang atau suatu pihak karena hubungannya yang khusus dengan orang atau pihak lain pada suatu tempat dan waktu tertentu serta situasi dan kondisi yang dianggap tepat.

\footnotetext{
114 Purnadi Purbacaraka dan A Ridwan Halim, Hak Milik Keadilan dan Kemakmuran tinjauan Falsafah Hukum, Penerbit Ghalia Indonesia, Jakarta 1986, hlm 7.
} 
Yang dimaksud dengan hak yang bersifat asasi ialah hak yang dipunyai oleh setiap orang dan tidak boleh diganggu gugat oleh siapapun dan dengan alasan apa pun, selama orang tersebut tidak menyalahgunakan haknya itu atau berbuatu sesuatu yang membahayakan atau merugikan orang lain. Dengan perkataan lain hak asasi itu adalah hak yang tidak dapat tidak, harus selalu menyertai kehidupan setiap orang dalam arti yang sewajarnya dan seharusnya, misalnya:

a. Hak untuk bebas bertindak dalam memenuhi kebutuhan hidup baik bagi dirinya sendiri maupun bagi orang lain yang menjadi tanggungan atau berada di atas bantuannya;

b. Hak untuk bebas berkumpul dengan orang lain;

c. Hak untuk bebas mempunyai pendapat sendiri;

d. Hak untuk bebas mencari berbagai hiburan dan kenikmatan hidup melalui berbagai cara yang dipandang baik menurut hemat masing-masing asalkan cara tersebut dibenarkan dan tidak mengganggu orang lain. ${ }^{115}$

Sedangkan hak yang tidak bersifat asasi ialah hak yang masih dapat dikesampingkan dari kehidupan seseorang karena adanya suatuatau beberapa kepentingan yang lebih memaksa. Kalau dalam hal tidak adanya suatu hak asasi harkat dan martabat seseorang sebagai manusia itu berkurang, maka tidaklah demikian halnya dengan hak yang tidak asasi ini. Tidak adanya satu atau beberapa atau mungkin juga ketiadaan sama sekali akan hak ini, tidak mengurangi harkat dan martabat seseorang sebagai manusia selain mungkin hanya mengurangi kenikmatan dan kebahagiaan hidup orang yang bersangkutan itu sendiri.

115 Purnadi Purbacaraka dan A Ridwan Halim, Hak Milik Keadilan dan Kemakmuran tinjauan Falsafah Hukum, Penerbit Ghalia Indonesia, Jakarta 1986, Ibid, hlm 8. 
Contoh hak yang tidak asasi misalnya, segala hak yang dapat diperoleh berdasarkan hukum tetapi masih dapat juga diganggu gugat (dalam arti dibatasi atau mungkin juga dihapus sama sekali) melalaui hukum itu sendiri bila ada satu atau beberapa kepentingan sebagai sebabnya yang lebih memaksa, yang antara lain adalah kepentingan umum.

Aneka hak tersebut antara laian ialah hak milik, hak pakai, hak sewa, hak usaha bagi hasil (yang dapat ada terhadap benda tetap maupun lepas), hak guna usaha, hak guna bangunan, hak membuka tanah, hak memngut hasil hutan (yang khusus ada dalam bidang keagrarian) dan sebagainya, yang kita ketahui bahwa kesemuanya mempunyai fungsi social, artinya penggunaannya selain ditujukan untuk kepentingan pemegangnya harus pula tidak mengganggu kepentingan umum (social) atau dengan perkata lain; pengguna hak tersebut di atas oleh pemegangnya tidak boleh disalahgunakan. ${ }^{116}$

Dengan demikian jelaslah sudah bagi kita sekarang bahwa hak yang asasi itu bersumber langsung dari aspek manusiawi kehidupan setiap orang yang bersifat abadi dan universal sedangkan hak yang tidak asasi itu bersumber dari aspek hubungan antar pribadi yang bisa berbeda menurut tempat, waktu, situasi dan kondisi. Letak hak milik yang menjadi inti pembicaraan dalam buku ini ialah didalam jenis hak yang tidak asasi, yang pada suatu saat dapat atau mungkin saja diganggu gugat bila kepentingan umum ternyata mendesaknya.

Tetapi apakah dengan adanya fungsi social yang melekat pada hak milik itu (Seperti juga pada hak lainnya), kita selalu dapat mengatakan bahwa demi

116 Purnadi Purbacaraka dan A Ridwan Halim, Hak Milik Keadilan dan Kemakmuran tinjauan Falsafah Hukum, Penerbit Ghalia Indonesia, Jakarta 1986, Ibid, hlm 8-9. 
kepentingan umum hak milik itu dapat mengatakan bahwa demi kepentingan umum hak milk itu dapat dibatasi atau dihapuskan dengan mudah begitu saja. Adakah dasar pertimbangan/jalan keluar lain yang adil selain dari pada jalan pikiran ini, mengingat setiap hak yang ada itu pada hakekatnya selalu mengandung usur keadilan didalamnya. Dengan perkata lain haruskah nilai keadilan yang telah tertanam dalam suatu hak milik itu (seperti juga pada hak lainnya) terhapus oleh adanya nilai lainl; walaupun sebagaimana adalah nisbi atau relatif. Adil bagi suatu pihak belum tertentu adil dirasakannya bagi pihak lain, atau adil bagi kita pada suatu waktu tertentu belum tentu kita rasakan adil pula pada waktu yang lain. Jadi bagaimanakah pemecahan masalah ini yang terbaik.

Penulis yakin bahwa masalah ini pasti sudah banyak atau seringkali berkecamuk dalam kalbu warga masyarakat pada umumnya dan para ilmuwan hukum pada khususnya. Melalui tulisan ini kita bahas, kita resapi dan kita hayati bersama hakekat, konsepsi dasar dan segala aspek riil dari pada hak milik yang secara praktis selalu kita jumpai dalam kehidupan masyarakat kita (Indonesia), disamping sambil lalu kita telah juga sebagai sekedar perbandingan dua aliran falsafah dasar yag dalam pengaturannya terhadap lembaga pemilikan ini masingmasing bersifat ekstrim dan salin berlawanan antara satu sama lain yakni individualisme (Amerika Serikat) dan komunalisme (Rusia). ${ }^{117}$

Dengan analisa yang bersifat falsafah penulis yakin bahwa kita akan dapat lebih mendalami, mengerti dan menghayati dengan sebenar-benarnya dan setepattepatnya hakekat, dasar kekuatan dan status lembaga pemilikan yang seharusny

\footnotetext{
${ }^{117}$ Purnadi Purbacaraka dan A Ridwan Halim, Hak Milik Keadilan dan Kemakmuran tinjauan Falsafah Hukum, Penerbit Ghalia Indonesia, Jakarta 1986, Ibid, hlm 9.
} 
hidup di Negara kita ini, sehingga kita sendiri mempunyai pandangan yang jelas pasti dan kokoh mengenai hal ini. Akibatnya kita tidak akan mudah terseret oleh berbagai pandangan lain yang seringkali sepintas lalu mungkin terasa "merayu", tetapi bila digali dasarnya tidak jarang akan memperlihatkan berbagai kekeliruan yang fatal karena pandangan atau pendirian tersebut kurang atau mungkin juga sama sekali tidak berkadar Filsafat Pancasila.

Tinjauan secara filsafat hukum, mengungkapkan bahwa apakah yang dimaksud dengan hak milik itu?

Hak ialah peranan bagi seseorang atau pihak (pemegangnya) untuk bertindak atas sesuatu yang menjadi obyek dari haknya itu terhadap orang lain. Jadi berdasarkan rumusan di atas, hak milik ialah peranan seseorang atau suatu pihak untuk memiliki sesuatu dan bertindak atas sesuatu yang menjadi miliknya itu.

Karena "hak" berarti peranan tetapi yang boleh, jadi tidak harus, dilaksanakan (boleh dilaksanakan dan boleh pulda tidak), maka pertama-tama kita harus menyadari bahwa setiap pemegang hak (hak apa saja) itu:

a. Tidak dapat dipaksa agar menggunakan haknya bila ia seandainya tidak mau menggunakannya dan demikian pula sebaliknya.

b. Tidak dapat dilarang atau dihalang-halangi bila ia hendak menggunakan haknya tersebut, sepanjang penggunaannya itu dilakukan dengan sebagaimana mestinya dalam arti tidak disalahgunakan dan tidak merugikan kepentingan orang lain.

Demikian pula halnya dengan hak milik dan pemegangnya.

Unsur kedua setelah "hak" ialah unsur "milik". Tentu saja yang menjadi obyek hak itu berupa sesuatu yang ebrsifat materiil/kebendaan. Dengan demikian 
jelaslah bahwa hak milik itu merupakan hak kebendaan, yakni hak yang obyeknya adalah benda atau yang dipermasakan dengan benda. ${ }^{118}$

Sebagai salah satu dari sekian banyak hak kebendaan, hak milik seperti yang telah kita ketahui merupakan hak kebendaan yang terkuat dan terpenuh di antara hak-hak kebendaan lainnya. Dikatakan demikian karena pemegang hak milik itu dapar berbuat apa saja terhadap barang miliknya itu, misalnya baik memakai/menguasainya sendiri maupun menjual, menyewakan, meminjam kepada pihak atau menguasakan orang lain untuk bertindak atas namanya dan atas kehendaknya terhadap benda miliknya tersebut untuk mewakili dirinya sebagai pemegang hak milik atas benda yang bersangkutan. Bahkan sampai merusakan atau memusnahkan benda miliknya tersebut pun secara yuridis tidak terlarang sepanjang perusakan atau pemusnahan tersebut tidak menggangu ketertiban dan tidak merugikan kepentingan orang lain.

Disamping itu hak milik pula yang merupakan satu-satunya hak kebendaan yang langgeng. Akibatnya setiap orang dapat sampai kapan saja atau lebih tegas lagi seumur hidup dapat menikmati manfaat harta benda yang telah menjadi miliknya sepanjang hak milik atas benda itu tidak dialihkan kepada orang lain. Bahkan bila orang tersebut telah meninggal dunia sekalipun, hak milik atas segala harta benda yang ditinggalkannya dengan sendirinya beralih kepada ahli waris atau para ahli warisnya.

Karena itulah maka hak milik merupakan pula satu-satunya hak yang dapat diperoleh dengan satu langkah pengorbanan saja, yakni usaha untuk mendapatkan

118 Purnadi Purbacaraka dan A Ridwan Halim, Hak Milik Keadilan dan Kemakmuran tinjauan Falsafah Hukum, Penerbit Ghalia Indonesia, Jakarta 1986, Ibid, hlm 10. 
benda-benda yang hendak dimiliki tersebut pada wal suatu pemilikan pada umumnya.

Kisah Perbudakan Buruh yang Menjadi Korban Dalam Pekerjaan Pada

\section{Masa Modernisasi ${ }^{119}$}

Seorang anak menjadi korban oleh karena berjuang untuk pengobatan orang tuanya, kisah nyata ini dilakukan oleh saudara Arif asli Lampung, dengan begitu gigihnya untuk kesembuhan orang tuanya, maka saudara Arif berangkatlah menuju kota Tangerang dimana menurut Arif kota Tangerang adalah Kota yang di idamidamkan karean merasa kota inilah untuk tempat mengaduh nasib demi kesembuhan orang tuanya, ternyata terbalik dari yang dibayangkan oleh sang korban (Arif) yang terjadi hanyala penderitaan yang tidak dapat terbayangkan oleh kedua orang tuanya. Kisah tersebut adalah kisah buruh sebuah pabrik yang mana pabrik tersebut adalah milik seorang saudagar Yuki Irawan yang kini telah menjadi tersangka dari hasil perbuatan yang menyekap semua karyawan dalam sebuah pabrik Kuali, hal tersebut dilakukan oleh saudara Yuki Irawan bersama-sama dengan beberapa anggotanya yang kini juga telah menjadi tersangka. ${ }^{120}$ Anehnya perbuatan itu telah diketahui oleh aparat penegak hukum yaitu Kepolisian, TNI, tangerang namun hal tersebut hanya dibiarkan terjadi karena saudara Yuki Irawan telah membayar oknum-oknum Kepolisian dan oknum TNI tersebut, pihak penegak hukum khususnya oknum Kepolisian, TNI, hanya membantu Yuki Irawan untuk menakut-nakuti para buruh tersebut, oleh karena itu peristiwa yang diderita oleh korban Arif dan kawan-kawan adalah merupakan peristiwa yang sangat

119 Hasil Rekaman Penulis melalui Media Elektronik, TV One tanggal 7 Mei 2013 Jam 21.30 WIB.

120 Ibid 
menyedihkan dan korban tersebut merasakan penderitaan berkali-kali untuk menjadi korban, baik korban yang tersiksa oleh karena ulah pengusaha yaitu Yuki Irawan, ditambah lagi penyiksaan dari oknum penegak hukum yaitu oknum Kepolisian dan oknum dari pihak TNI, dan yang sangat memiluhkan perasaan korban yang diberi nama Arif tersebut adalah penderitaannya yang secara langsung dilakukan oleh Pemerintah. Menurut penulis mengapa dikatakan korban secara langsung karena pemerintah tidak sigap, kurangnya pengawasan, memberikan peluang kepada pengusaha yang tidak bermoral, serta tanpa mencek keadaan karyawan khususnya Depnaker, umtuk itu dalam penulisan buku ini penulis memberikan keterangan bahwa pengusaha yang bernama Yuki Irawan tersebut adalah pengusaha biadab, mengapa penulis menyatakan demikian karena para karyawannya tidak diberi gaji, tidak diberikan fasilitas tempat kerja yang layak, karyawannya tidak dapat mengganti baju, tidak dapat keluar rumah, tidur ditempat yang tidak layak bagi manusia, apa alasannya penulis menyampaikan tidak layak oleh karena tempat tidur tersebut adalah tempat dimana karyawan dari Yuki Irawan mandi, disitu pulalah karyawannya harus menginap, maka disuatu saat karyawannya mendapatkan penyakit yamg dapat menggangu kehidupan masa depannya. Penyakit yang diderita oleh para buruh tersebut adalah gatal-gatal, penyakit kulit, rasa mau gila, steress, rasa takut terhadap Kepolisian, mengapa penulis menyatakan demikian karena inilah fakta yang secara lansung di rasakan oleh korban kekejaman seorang saudagar Yuki Irawan, seorang dapat diperdaya oleh karena kekayaanya, namun secara kemanusian itu tidak layak di lakukan karena pekerja itu adalah insan manusia bukanlah seorang binatang. 
Pabrik Kuali milik Yuki Irawan (41 tahun) di Tangerang membuat seluruh Indonesia terhenyak. Betapa tidak, Pabrik tersebut menyimpan cerita menyakitkan, ketika puluhan buruh_harus hidup dengan cara diperbudak sang majikan: tanpa upah dan bekerja tanpa lelah. Banyak yang disiksa secara fisik maupun secara mental. $^{121}$

Cerita seputar Pabrik Kuali tersebut demikian kelabu dan akan terbayangkan kisah masa penjajahan yang harus bekerja rodi. Pabrik yang omset sebulannya mencapai 100 juta, mempekerjakan buruh tanpa memberi upah. Setiap buruh yang baru masuk kerja ataupun yang telah lama bekerja pada suatu pabrik mili Yuki Irawan Tersebut, harus merasakan barang-barang mereka dilucuti. Mulai dari dompet hingga handphone. Puluhan orang pun harus tidur dalam satu ruangan berukuran $8 \times 8$ meter dengan alas tikar dan ruang pengap. Buruh-buruh ini dilarang bersosialisasi. Jika pekerjanya lambat maka akan menjadi korban penyiksaan yang tak manusiawi yaitu dipukul maupun mendapat ancaman akan ditembak oleh oknum Brimop .

Seorang buruh bernama Bagas (22 tahun) mengaku belum mendapatkan hak selama enam bulan bekerja. "Jangankan Rp 100, satu sen pun saya belum pernah megang. “ sehingga korban memberanikan diri untuk menyampaikan agar dapat dipinjamkan telepon guna untuk menghubungi sank keluarga maupun kedua orang tuaku, namun apa yang terjadi pada diri korban pertama korban diajak masuk ke ruangannya. Ternyata sampai di ruangan yang telah disiapkan untuk korban, ternyata korban hanya mendapatkan siksaan yang tidak manusiawi yaitu dipukuli, ditendang, dibentak, dicacimaki, namun setelah puas atas penyiksaan tersebut lalu

121 Ibid. 
korban dibawa ke gudang untuk di kurung agar bekas hasil tindak pidana tersebut tidak tertanpakan oleh orang-orang yang didekat korban," itulah penuturan korban" .122

Peraturan untuk Jam kerja di pabrik kuali milik Yuki Irawan tersebut adalah sangat tidak manusiawi. Dimana hal tersebut Para korban perbudakan diharuskan untuk memulai aktivitasnya yaitu pukul 05.30 hingga 22.00. Dengan siksaan atau paksaan untuk melakukan pekerjaan yang begitu memerlu tenaga yang begitu besar, namun korban hanya mendapatkan makanan dua kali sehari yaitu setiap pukul 12.oo WIB (makan siang) dan pukul 18.00 WIB (makan malam) dengan lauk pauk yang seadanya. Namun menurut korban dari perbudakan (pekerja) suatu Pabrik Kuali milik saudara Yuki Irawan di Tangerang, menuturkan bahwa korban hanya mendapat sekali jatah makan itupun terkadang hanyala nasi dingin yang tak mempunyai sambal.

Dengan peristiwa ini ternyata ada temuan yang sangat meresahkan masyarakat di lingkungan Pabrik milik Yuki Irawan yaitu ditemukannya sebuah kuburan di pabrik kuali milik Yuki Irawan. Namun dari hasil penyelidikan aparat penegak hukum (Polri), makam tersebut adalah makam dari putri pemilik pabrik kuali yang bernama Yuki Irawan, dimana hal tersebut peristiwa yang menimpa anak dari saudara Yuki Irawan tersebut adalah akibat kurangnya kebersihan dalam suatu lingkungan pabrik yang dimiliki oleh saudara tersangka Yuki Irawan yang menyebabkan meninggalnya anak tersebut karena diakibatkan oleh suatu peristiwa

122 Ibid. 
muntaber, dimana anak dari pemilik pabrik kuali saudara tersangka Yuki Irawan tersebut ketika anak tersebut baru berusia lebih kurang tiga tahun. ${ }^{123}$

Dalam hal ini, tindakan yang dilakukan oleh saudara Yuki Irawan pemilik pabrik kuali tersebut adalah merupakan pelanggaran hukum berat, melakukan kejahatan bisnis yang secara terorganisir serta melakukan pelangaran-pelanggaran hukum lainnya baik secara hukum pidana, hukum perdata maupun secara hukum ketatanegaraan. Untuk itu penulis dalam buku "Penghukuman Tanpa Hakim" agar sekiranya para pejabat pemerintahan dari kalangan bawah sampai dengan pucuk pimpinan atas (Presiden Republik Indonesia), diharuskan tanggap terhadap persoalan-persoalan yang ada di Republik ini khususnya Republik Indonesia yang kita cintai, kita banggakan, karena perjuangan untuk mendapatkan sesuatu kebebasan dalam menjalankan kehidupan dari masa dulu sampai sekarang adalah mengeluarkan pengorbanan baik secara materiil, secara mental (Phisikologis), serta mempertaruhkan nyawanya dari pada pejuang untuk mendapatkan kehormatan dimata Bangsa-bangsa di Dunia, namun bila kita simak kejadian yang terjadi pada zaman modern ini seharusnya tidak lagi terjadi seperti yang terjadi di Pabrik Kuali milik Yuki Irawan yang berlokasi di Tanggerang dan Lampung tersebut. Untuk itu penulis dalam buku yang berjudul "Penghukuman Tanpa Hakim" tersebut menegaskan bahwa ancaman yang akan diterima oleh saudara Yuki Irawan pemilik pabrik kuali tersebut bukan hanya ancaman pidana saja namun ancaman ganti kerugian secara perdata maupun ancaman secara hukum ketatanegaraan tentang administrasi pembayaran pajak harus diterapkan agar kedepan para pengusaha

123 Ibid. 
mendapatkan pemerhati dalam suatu aturan yang ada sesuai dengan Undangundang yang telah ditentukan. ${ }^{124}$

Dari hasil penyelidikan Polri mengungkapkan secara jelas bahwa makam yang ditemukan dilingkungan rumah Saudara Yuki Irawan tersebut adalah makam dari putrinya Yuki yang meninggal tahun 1997 karena sakit muntaber,” kata Rikwanto, Kepala Bidang Humas Polda Metro Jaya.

Yuki Irawan sendiri kini harus menanggung semua perbuatannya. Polisi menjeratnya dengan berbagai pasal berlapis. Termasuk tidak adanya izin usaha industri, mempekerjakan buruh di bawah umur, tindak perdangangan secara manusiawi, tidak bermoral, dan turut serta menggelapkan barang-barang milik para buruh yang bekerja pada perusahaan yang ia pimpin.

Polda Metro Jaya terus mendalami keterlibatan aparat yang diduga ikut terlibat dalam kasus penyiksaan buruh di pabrik kuali di Tangerang. Kepala Bidang Humas Polda Metro Jaya Kombes Rikwanto di Jakarta, Selasa (7/5), mengatakan pihaknya telah mengidentifikasi dua aparat kepolisian berinisial AH dan J, serta satu anggota TNI berinisial IS yang diduga ikut terlibat dalam suatu tindak pidana untuk membantu tersangka Yuki Irawan umur 41 tahun sebgai pemilik pabrik kuali dalam mengintimidasi pekerjan para buruh tersebut.

Untuk itu Polri melalui penyelidikan dan kerja keras bersama masyarakat setempat (Tangerang) agar dapat terungkap segala perbuatan tindak pidana kekerasan terhadap buruh pabrik milik Yuki Irawan yang terorganisir tersebut, terhadapnya bukti-bukti apa saja yang dialami oleh buruh maupun seperti apa kedekatan aparat dengan tersangka, kami akan melakukan pemeriksaan pada 124 Ibid. 
minggu ini. Mudah-mudahan dari pemeriksaan bisa terungkap," kata Kepala Bidang Humas Polda Metro Jaya Kombes Rikwanto di Jakarta.

Dijelaskannya, berdasarkan keterangan sementara yang didapat dari lingkungan sekitar, serta pengakuan buruh dan tersangka Yuki, dipastikan ada tiga aparat yang kerap mampir ke rumah tersangka. Ketiga aparat tersebut, lanjut Rikwanto, adalah teman dari saudara Yuki. Mereka kerap berkunjung. Tersangka juga pernah memberikan uang kepada mereka. Misalnya, tersangka Yuki memberikan uang sebesar Rp100.000 sebagai uang bensin kepada ketiga oknum Brimop dan TNI tersebut.

Namun secara tegas, Kepala Bidang Humas Polda Metro Jaya Kombes Rikwanto di Jakarta melalui media elektronik tv one, memberikan penjelasan bahwa kepolisian akan terus mendalami apakah ketiga aparat itu benar-benar hanya memiliki hubungan pertemanan atau apakah peranannya dimanfaatkan untuk mengintimidasi para buruh dan/atau apakah kehadiran dari oknum Brimop dan TNI tersebut dimanfaatkan oleh Yuki untuk menakut-nakuti atau mengintimidasi para buruh, menurut Kepala Bidang Humas Polda Metro Jaya Kombes Rikwanto di Jakarta hal tersebut sedang kami dalami.

Seperti diberitakan sebelumnya, sebanyak 34 buruh yang dipekerjakan dengan buruk di sebuah pabrik kuali di Kampung Bayur Opak RT 03/06, Desa Lebak Wangi, Kecamatan Sepatan Timur, Tangerang, mendapat perlakuan buruk dari bos mereka. Penyekapan buruh di pabrik kuali itu terkuak setelah dua buruh yang bekerja di pabrik itu berhasil melarikan diri. Kedua buruh yakni Andi 
Gunawan, 20, dan Junaidi, 22, kabur setelah tiga bulan dipekerjakan dengan tidak layak. $^{125}$

Kepolisian telah menetapkan tujuh tersangka dalam kasus ini. Pemilik industri Yuki Irawan dan empat orang mandor pabrik saat ini telah diamankan. Sementara dua calo, yakni J dan U, masuk daftar pencarian orang (DPO) dan terus diburu kepolisian.

Polres Tangerang Kota hingga kini masih memburu dua orang calo buruh yakni $\mathrm{T}$ (sebelumnya ditulis $\mathrm{J}$ ) dan $\mathrm{U}$, yang diketahui terlibat dalam perekrutan calon pekerja untuk Yuki Irawan (41), tersangka kasus penyiksaan buruh. Sebelumnya, salah satu mandor Yuki Irawan yang berinisial (TD) yang pertama memperkenalkan Yuki kepada dua calo buruh tersebut.

Dengan hal tersebut diatas, maka Penyidik Polri sedang menelusuri siapa yang kenal dengan dua orang oknum yang mengenalkan Yuki dengan calon pekerjanya. Namun di antara mandor tersebut ternyata ada yang kenal dengan mereka (calo buruh), menurut Kabid Humas Polda Metro Jaya Kombes Penulis, di Mapolda Metro Jaya, pada hari Jumat tanggal 10bulan 5 tahun 2013. Mandor tersebut ialah TD yang saat ini telah ditetapkan sebagai tersangka. Karena menurut pengakuannya TD adalah yang melakukan perekrut buruh di wilaya Lampung dan Tangerang. Sebelumnya, diketahui perekrutan puluhan pekerja pabrik kuali di Tangerang diketahui melalui seorang 'calo'. Menurut keterangan sementara dari para buruh, penyidik mendapatkan dua nama yakni $\mathrm{T}$ dan $\mathrm{U}$ yang kerap mencari pekerja di daerah Lampung dan Jawa Barat khusunya Cianjur. ${ }^{126}$

\footnotetext{
125 Ibid.

126 Ibid.
} 
Berdasarkan uraian di atas, secara prinsip KUHAP sudah mengatur hak-hak tersangka dan korban dalam proses peradilan pidana di Indonesia. Namun demikian pelaksanaannya selama ini, masih jauh asap dari panggang.

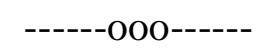




\section{DAFTAR PUSTAKA}

\section{A. Buku-Buku}

A. Hamzah dan Irdan Dahlan. Perbandingan KUHAP HIR dan Komentar. Penerbit Ghali Indonesia. Jakarta, 1984.

Adhi Wibowo. Diktat Bahan ajar Ilmu tentang Viktimologi Fakultas Hukum Universitas Ekasakti, Padang, 2006

Andi Hamzah, Pengsutan Perkara Kriminal Melalui Sarana Teknik dan Sarana Hukum, Ghalia Indonesia, Jakarta, 1984.

Bambang Waluyo, Viktimologi Perlindungan Korban dan Saksi. JakarIta. Penerbit. Sinar Grafika, 2011

Cesare Lombroso, dalam W.A.Bonger, Pengantar Tentang Kriminologi, PT. Pembangunan, Jakarta, 1995

Chanur Arrasjid. Pengantar Psikologis Kriminal. Penerbit. Yani Corporation. Medan 1988.

Departemen Kehakiman AS, Kantor Pengembangan, Asisten dan Pelatihan Kerja Sama Luar Negeri (OPDAT) dan Kantor Kejaksaan RI (Pusdiklat), Perdagangan Manusia dan Undang-Undang Ketenagakerjaan: Strategi Penuntutan yang Efektif, 2008

Farhana, Aspek Hukum Perdagangan Orang di Indonesia, Penerbit Sinar Grafika, Jakarta, 2010

H.Harris,Pembaharuan Hukum Acara PIdana yang terdapat dalam H.I.R. Penerbit Binacipta, Jakarta 1978

Ilhami Bisri Sistim Hukum Indonesia Penerbit, PT. RajaGrafindo Persada Jakarta,2007

Indah Sri Utari, Aliran dan Teori dalam Kriminologi, Thafa Media. Semarang 2012. Julaiddin, Viktimologi dalam makala tentang beberapa aspek korban kejahatan. Tahun 2012

J.E Sahetapi. Viktimologi Sebuah Bunga Rampai Penerbit. Pustaka Sinar Harapan, Jakarta Tahun 1987.

Julaiddin, Hasil Rekaman Penulis melalui Media Elektronik, TV One tanggal 7 Mei 2013 Jam 21.30 WIB. 
Julaiddin. Materi Perkuliahan tentang Korban Kejahatan (viktimologi) Penghakiman tanpa Hakim tahun Akademik 2012-2013.

Lih Bernard L. Tanya,et al, Teori Hukum, Yogyakarta: Genta Publishing, 2011 Moerti Hadiati Soeroso,S.H.,M.H Kekerasan Dalam Rumah Tangga Dalam Perspektif Yuridis-Viktimologis Penerbit SInar Grafika, Jakarta 2010

Moelyatno, Kitab Undang-Undang Hukum Pidana. Penerbit Bumi Aksara. Jakarta, 2003.

Mulyadi L. Kapita selekta Hukum Pidana Kriminologi dan Viktimologi. Penerbit. Djambatan, Jakarta, 2003

Nashriana, Perlindungan Hukum Pidana Bagi Anak di Indonesia Penerbit PT. Raja Grafindo Persada, Jakarta, 2011.

Romli Atmasasmita, Bunga Rampai Kriminologi. Penerbit. CV. Rajawali. Jakarta 1984.

Ruth Rosenberg, Perdagangan Perempuan dan Anak Indonesia, Jakarta:USAID, Tahun 2003

Supriyadi Widodo Eddyono, Perdagangan Manusia dalam Rancangan KUHP, cet.1, Jakarta: ELSAM, 2005

Topo Santoso dan Eva Achjani Zulfa, Kriminologi, Raja Grafindo Persada, Jakarta,2006

Zainal Abidin Farid, Hukum Pidana I. Penerbit Sinar Grafika Jakarta. 1995.

\section{B. Peraturan Perundang-undangan}

Undang Undang Dasar Negara Republik Indonesia Tahun 1945

Undang-Undang Nomor 39 Tahun 1999 tentang Hak Asasi Manusia.

Undang-Undang Nomor 23 Tahun 2002 tentang Perlindungan Anak.

Undang-Undang Nomor 23 Tahun 2004 tentang Penghapusan Kekerasan Dalam Rumah Tangga.

Undang-Undang Nomor 7 Tahun 1984 tentang Penghapusan Segala Bentuk Diskriminasi terhadap Perempuan.

Undang-Undang Nomor 23 Tahun 1992 tentang kesehatan

Undang-Undang Nomor 13 Tahun 2006 tentang Perlindungan Saksi dan Korban. 
Undang-Undang Nomor 13 Tahun 2003 tentang KetenagaKerjaan.

Undang-Undang Nomor 39 Tahun 2004 tentang Penempatan Perlindungan Tenaga Kerja Indonesia di Luar Negeri.

Undang-Undang Nomor 9 Tahun 1992 tentang Keimigrasian.

Undang-Undang Nomor 15 Tahun 2002 tentang Tindak Pidana Pencurian Uang.

Undang-Undang Nomor 20 Tahun 2001 tentang Perubahan atas Undang-Undang Nomor 31 Tahun 1991 tentang Penghapusan Korupsi, dan lain-lain 


\section{BIOGRAFI PENULIS}

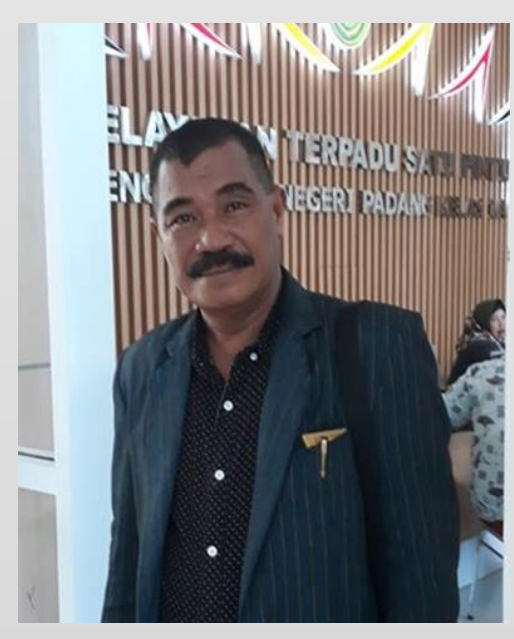

Julaiddin Samu seorang putra suku Bugis yang lebih dikenal dengan panggilan Laode, lahir di Usuku Buton pada tanggal 17 Agustus 1967. Penulis menyelesaikan sekolah dasar di SD Negeri UsukuTomia, SMP Negeri Usuku Tomia, dan SMA Manuru Bau-Bau Buton. Penulis memiliki pengalaman kerja sebagai pelaut dengan berbekalkan Ijazah AMK.PT, dan pengusaha dalam bidang Logistik di PT. Andalas Nusantara Terang. Kemudian bekerjasama dengan Dinas Pendidikan untuk mengantarkan buku-buku dalam program Dana Bantuan Operasional Sekolah ke daerah pelosok-pelosok

di Sumatera Barat, dan berlabuhlah di salah satu SMA, yaitu SMA Ekasakti. Berawal dari perjalan penulis ke SMA Ekasakti, penulis di perkenalkan dengan Rektor Universitas Ekasakti, dari jabat tangan pertama tersebutlah kehidupan baru di mulai sebagai seorang Akademik. Penulis melanjutkan Pendidikan S-1 dan S-2 pada Program Studi Ilmu Hukum Universitas Ekasakti. Sekarang penulis bekerja sebagai Dosen Tetap Ilmu Hukum di Fakultas Hukum Universitas Ekasakti Padang.

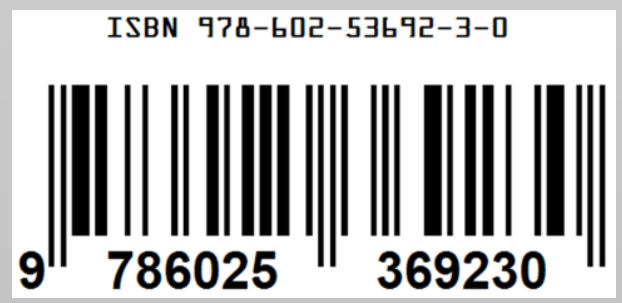

